Universidade de São Paulo

Faculdade de Educação

Programa de Pós-graduação: Mestrado

Elody A. Nunes Moraes

A IMPORTÂNCIA DOS MODELOS

NAS ATIVIDADES DE ESCRITA

E A LIBERDADE DE CRIAÇÃO

Dissertação apresentada como exigência parcial para obtenção do título de Mestre em Educação

Linha de Pesquisa: Linguagem e Educação

Orientador: Prof. Dr. Nilson José Machado

São Paulo

2009 
Autorizo a reprodução e divulgação total ou parcial deste trabalho, por qualquer meio convencional ou eletrônico, para fins de estudo e pesquisa, desde que citada a fonte.

Catalogação na Publicação

Serviço de Biblioteca e Documentação

Faculdade de Educação da Universidade de São Paulo

371.34

M827i
Moraes, Elody A. Nunes

A importância dos modelos nas atividades de escrita e a liberdade de criação / Elody A. Nunes Moraes ; orientação Nilson José Machado.

São Paulo : s.n., 2009.

$188 \mathrm{p}$.

Dissertação (Mestrado - Programa de Pós-Graduação em Educação.Área de Concentração : Linguagem e Educação) - - Faculdade de Educação da Universidade de São Paulo.

1. Livro didático 2. Leitura 3. Escrita 4. Estudantes de ensino fundamental - Produção - Textos gerais I. Machado, Nilson José, orient. 
Não, não tenho caminho novo.

O que tenho de novo é o jeito de caminhar.

Thiago de Mello 


\section{AGRADECIMENTOS}

Ao Edson, meu marido, que tanto me ajudou na realização deste trabalho, e também de muitos outros, com seu amor e o seu conhecimento, sempre me mostrando graça na vida. A minha filha Amanda, luz para os meus pensamentos, que, ao aprender a ler, me fez ter a certeza de que saber escrever é uma conquista para a autonomia.

Aos meus pais, Eneida e Arlindo, pelo carinho e incentivo, desde sempre, ajudando-me em todos os desafios pelos quais me lancei nesta vida.

Aos meus irmãos, Fernanda e Beto, pessoas que sempre tenho a certeza de que posso contar, pelas ajudas tão preciosas. Aos meus sogros, cunhados, sobrinhos e afilhada que souberam compreender minhas ausências.

Ao meu orientador, professor doutor Nílson José Machado, grande mestre e amigo, que me conduziu por mares nunca antes navegados, responsabilizando-se, junto comigo, por todo este processo. A todos os meus alunos, diretos ou indiretos, que me ajudaram a descobrir novos caminhos pelos desafios da educação. 


\section{SUMÁRIO}

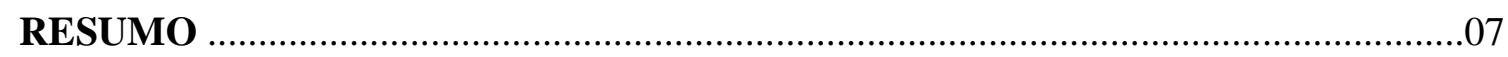

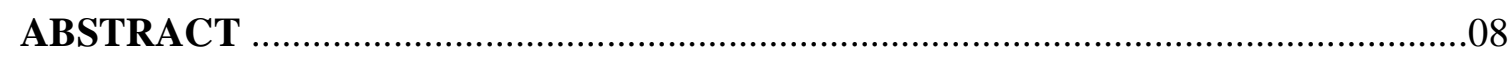

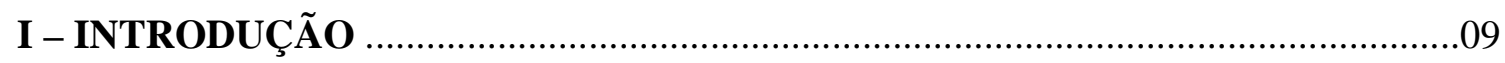

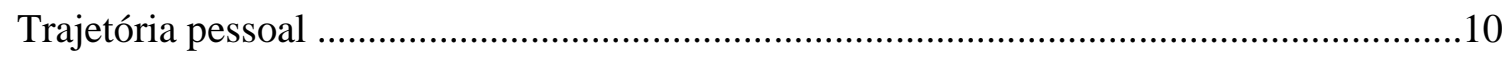

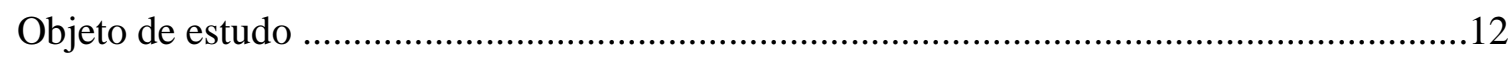

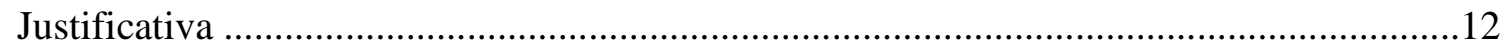

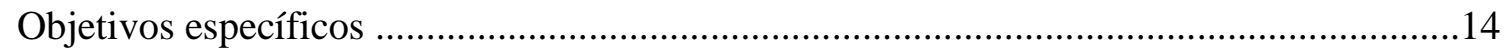

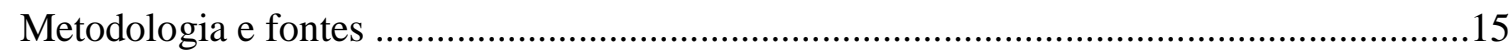

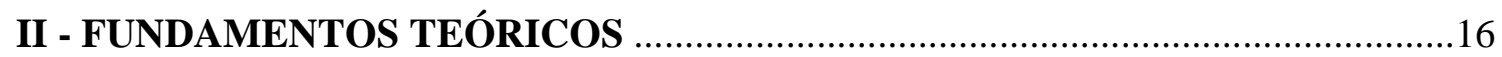

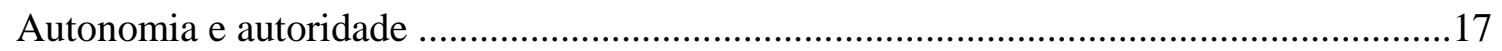

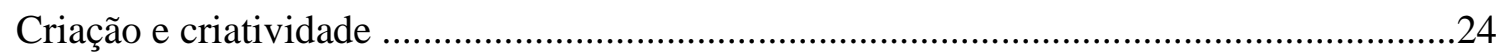

Intertextualidade, paráfrase e reprodução ......................................................................

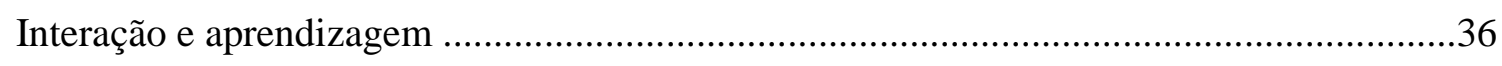

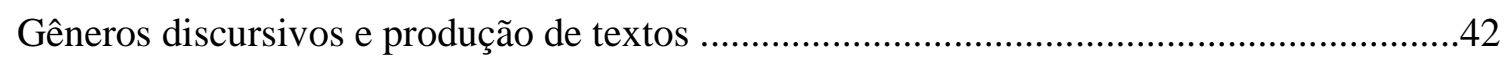

III - ASPECTOS DIDÁTICOS E METODOLÓGICOS ..........................................

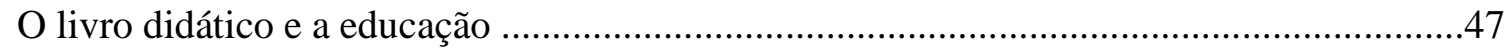

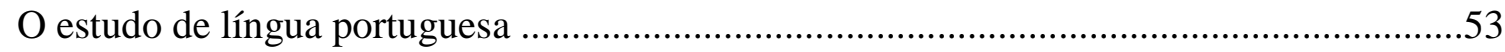

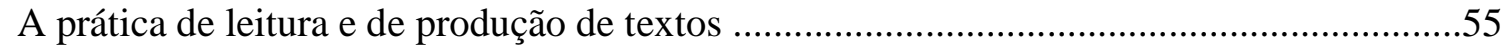


Aspectos considerados na seleção das propostas de produção de texto ............................68

Principais aspectos teóricos e metodológicos dos livros analisados ..................................71

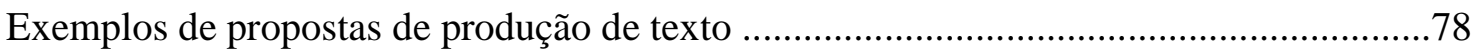

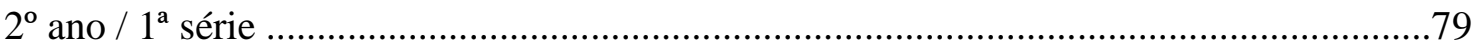

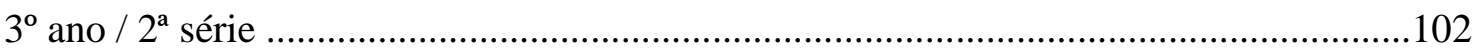

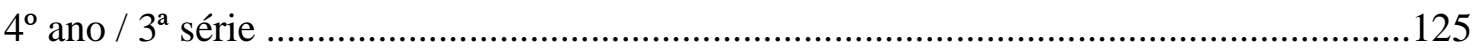

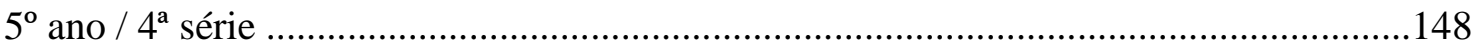

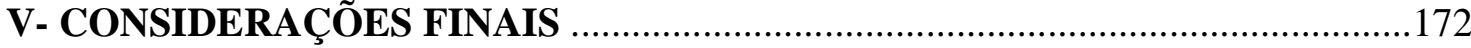

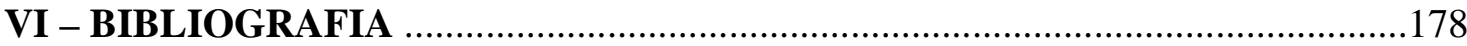

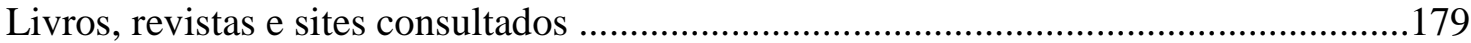

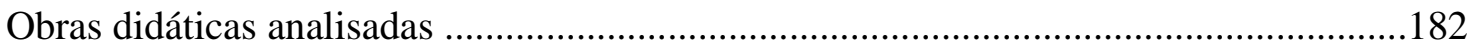

VII - ANEXO

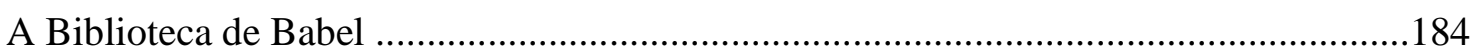




\section{RESUMO}

A leitura e a escrita são importantes ferramentas para ajudar os alunos a melhor compreenderem o mundo ao seu redor. É preciso conhecer, ler, analisar e reproduzir modelos de qualidade para que seja possível escrever textos de forma mais competente. Neste sentido, as propostas de escrita podem incentivar a paráfrase de bons modelos com a finalidade de auxiliar os alunos a se comunicarem melhor, até que se constituam como autores mais autônomos. Mas, até que ponto o contato com os modelos pode afetar a liberdade de criação? É possível copiar um modelo e construir a própria autonomia ao mesmo tempo? Para responder a estas questões, George Steiner, em seu livro Gramáticas da criação, defende a idéia de que estamos a todo o momento "imitando", ou melhor, repetindo modelos, ações e idéias de outros. De um modo geral, a criação estaria muito mais próxima da paráfrase do que daquilo que é visto como novo, como original. Bakhtin também disserta sobre o quanto somos ecos de outras vozes que nos cercam, repetindo idéias que não são só nossas, mas que circulam socialmente e influenciam nosso modo de pensar e de agir; interações essas que se estabelecem entre as pessoas e que nos permitem avançar em nossos conhecimentos, de acordo com a teoria sócio-cultural desenvolvida por Vygotsky. Neste sentido, é possível levantar algumas idéias sobre o papel da escola e também dos livros didáticos nesse processo de criação, ou seja, no desenvolvimento da autoria dos alunos. Neste estudo, pretende-se analisar o modo como se relacionam cópia, reprodução, paráfrase e autoria no processo de construção da autonomia dos alunos a partir das metodologias presentes nas atividades de escrita propostas nos livros didáticos. Foram analisadas seis obras de grande adoção nas escolas e que são aprovadas pelo Programa Nacional do Livro Didático. Em todas elas observou-se a presença de boas estratégias, cujo principal objetivo era apresentar um bom modelo para que o aluno conseguisse ressignificá-lo e, a partir dele, desenvolver o seu próprio texto. Partiu-se da concepção de que a criação humana é sempre mediada por algo que já existe e que não se trata de uma simples repetição: há trabalho dos sujeitos nisso, pois o autor é na verdade um "aumentador", ele aumenta o mundo a partir de algo que já existe. Podemos considerar, portanto, que a idéia de criatividade relaciona-se, na verdade, com a idéia de transformação da realidade e que esse processo está presente nos materiais didáticos atuais, enquanto uma boa estratégia para formar escritores mais competentes.

PALAVRAS-CHAVE: produção de texto, autonomia, livro didático 


\begin{abstract}
Reading and writing are important tools that can be used by students to enhance their understanding about the world and the environment around them. The ability of writing requires prior knowledge of certain quality standards that must be properly evaluated and reproduced if one wishes to accomplish a good quality text. Thus, the best way to enhance a student's writing ability might be through writing propositions that stimulate the paraphrases of good text models, aiming at helping their communications skills, until the autonomy in writing is fully developed. In this case, however, a few important points must be considered: can such text models affect the student's creativity? Is it possible for a student to copy/comply to a model text and, yet, develop his/her own autonomy at the same time? To answer such questions, George Steiner, in his book Grammars of Creation, points that we are always "copying", or repeating models, actions or ideas learned from other people. In a general sense, creation would be much closer to paraphrases than from what is understood as "original". Bakhtin agrees with this idea, pointing that we can be "echoes" from other voices around us, repeating ideas that are not just ours, but belong to our social environment and influence our thoughts and actions. This is one of the major driving forces to the development of our knowledge, according to Vigotsy's Social-cultural Theory. Thus, it is possible to draw a few ideas concerning the role(s) that must be played by the school and the textbooks in the process of developing the students as efficient and autonomous authors of written texts. It is necessary to teach students to find new meanings to the model texts, so they can go beyond copying and reproducing other people's texts, and start creating upon such new ideas, until their writing develops into true authorship. The evaluation of writing propositions contained in school textbooks might be a good way to determine how it is possible to help students to develop this process. In this work, we evaluated the interplay among copy, reproduction, paraphrases and authorship during students' development as independent writers. We considered the methodologies inherent to the writing propositions found in six different school textbooks all of them are widely used in schools across the country and have been approved by the "Programa Nacional do Livro Didático". All textbooks contained appropriate exercises, in which the main objective was to force students to define new meanings to model texts, developing these new ideas into an original text. Our main concept is that human creation, although often dependent on previously conceived models, cannot be considered a simple act of repetition; there is genuine input from the author, which can be viewed as an "enhancer" in this process, as he/she adds upon pre-existing models to develop original ideas. In this sense, creativity is directly associated with a process of transformation of the current reality and most school textbooks can be used to develop strategies to form competent writers.
\end{abstract}

KEYWORDS: Text production, autonomy, school textbooks 


\section{INTRODUÇÃO}

CAMPOS DE CASTILLA (1907-1917)

Desdeño las romanzas de los tenores huecos y el coro de los grillos que cantan a la luna A distinguir me paro las voces de los ecos y escucho solamente, entre las voces, una.

MACHADO, Antonio. Poesias Completas. Madrid, Espasa-Calpe, S.A., 1979, p. 133 


\section{Trajetória pessoal}

Minha carreira está voltada para a educação desde 1984: fui professora de Educação Infantil em salas de jardim e de alfabetização por seis anos e, desde 1990, sou professora no Ensino Fundamental - o que considero um grande desafio e um enorme prazer! Atualmente também dou assessoria pedagógica em escolas das redes particular, estadual e municipal.

Desse trabalho com os alunos, surgiu também um diálogo com os professores: em 1998 iniciei uma parceria com a editora Moderna, onde passei a produzir materiais didáticos na área de Língua Portuguesa para o segmento do Ensino Fundamental I.

A partir dessa atividade, passei a me questionar sobre qual seria a melhor maneira de encaminhar os exercícios, principalmente os que envolvessem a escrita, de forma que os alunos entrassem em contato com bons modelos de texto, apropriando-se das suas estruturas, mas tendo liberdade para criar suas próprias histórias.

Esta busca me trouxe ao mestrado, cujas disciplinas cursadas muito contribuíram para a fundamentação teórica desta pesquisa.

Ao entrar em contato com as idéias desenvolvidas por Arendt, em seu livro Entre o passado e o futuro, foi possível compreender como a autoridade se manifesta em nossa sociedade. Também foi possível observar como os alunos se apropriam do conhecimento articulando informações, por meio das idéias de Machado acerca da comparação entre conhecimento e informação. Partindo deste pressuposto, não basta a escola apenas passar informações aos alunos. É preciso que articulem essas informações para que realmente possam compreendê-las. Segundo Machado, é preciso ajudá-los a construir o seu próprio conhecimento por meio da ação; porém, uma ação que seja consciente, baseada na capacidade de projetar, ou seja, de produzir projetos e de abstrair.

Dessa relação com o mundo ao seu redor, foi possível analisar os processos intelectuais à luz das idéias de Vygotsky sobre o desenvolvimento humano e as relações entre cultura e pensamento, em seus livros Pensamento e linguagem e Formação social da mente. Segundo este autor, o homem é constituído de dois tipos de funções — as biológicas ou naturais, que pertencem à memória genética da espécie, e as culturais, presentes na história social humana. Nesse sentido, a relação do indivíduo com o mundo é sempre mediada por algo, como instrumentos ou pessoas, por 
exemplo, e acaba sendo baseada na imitação. Por meio das idéias de Bakhtin, desenvolvidas em seus livros Estética da criação verbal e Marxismo e filosofia da linguagem, foi possível observar que quando uma pessoa produz um texto é autor desse discurso, mas é também produto de várias vozes; ou seja, reproduz a tradição e os modelos com os quais teve contato. Nesse sentido, a cultura é um elemento importante para o desenvolvimento humano, mas não o único. Conforme assinala Rego, em seu livro Memórias de escola, cada sujeito é único e pode ter as suas interpretações e significações diferenciadas acerca da influência da cultura sobre o seu desenvolvimento.

A partir das idéias sobre a dialética que se estabelece entre o sujeito e o outro e como isso se inscreve nas atividades de escrita, partiu-se da concepção de que esse tipo de linguagem não é produzida sem uma interação. É por meio dessa interação que o sujeito reinterpreta as informações que recebe e compartilha seus conhecimentos de mundo com seus pares. Assim também o livro didático atuaria como uma ponte entre o sujeito e o conhecimento. De acordo com as idéias de Geraldi, em seu livro Portos de passagem, foi possível perceber como o livro didático cada vez mais passou a fazer parte da rotina da sala de aula. Assim, o professor é orientado sobre como auxiliar os alunos a avançarem em seus conhecimentos, colocando em movimento vários processos de desenvolvimento que, sem a ajuda externa, seriam mais difíceis de ocorrer.

A partir dessa fundamentação teórica, optei por desenvolver este estudo em 5 capítulos: O capítulo I apresenta o tema de estudo e sua justificativa; o capítulo II retoma teoricamente os principais conceitos que fundamentam a minha hipótese, trazendo discussões acerca da noção de: autonomia e autoridade, criação e criatividade, intertextualidade, paráfrase e reprodução, interação e aprendizagem e, por fim, a abordagem dos gêneros discursivos. O capítulo III apresenta o percurso do livro didático na história da educação e a forma como leitura e produção de textos são articulados na sala de aula. A partir do capítulo IV são analisados trechos de livros didáticos, com um enfoque nas atividades de leitura e de produção de textos. O capítulo V traz a conclusão do estudo e os capítulos VI e VII a bibliografia consultada e os anexos. 


\section{Objeto de estudo}

Analisar o modo como se relacionam cópia, reprodução, paráfrase e autoria no processo de construção da autonomia dos alunos a partir das metodologias presentes nas atividades de escrita propostas nos livros didáticos.

\section{Justificativa}

É função da escola ensinar seus alunos a ler e a escrever de forma competente. Nessa perspectiva, o ensino da Língua Portuguesa deve servir como um instrumento que possibilite uma melhor participação na sociedade. A escola deve assumir a responsabilidade de garantir ao aluno o uso da língua de forma eficaz, compreendendo o mundo que o cerca e ajudando-o a expressar-se de maneira adequada.

Para aprender a escrever, é preciso escrever. É fundamental que o aluno tenha muitas oportunidades para fazê-lo; quanto mais fizer isso, mais aprenderá sobre o funcionamento da escrita. Porém, ensinar a escrever na escola também implica em estabelecer uma relação ativa entre leitura e escrita. Por meio da leitura e da análise textual, é possível entrar em contato com as características da linguagem escrita que serão necessárias acionar ao escrever.

Nesse processo, aprender a ler de forma competente é muito mais do que decifrar mensagens; trata-se de procurar um sentido e questionar algo escrito a partir de uma realidade.

Ao ler, entramos em sintonia com as idéias e os sentimentos de outras pessoas. Segundo Bakhtin, o autor é sempre co-autor, ou seja, produto de várias vozes. Traz consigo idéias que não necessariamente sabe de onde veio, ecoando as vozes de uma tradição, as influências da sua cultura, dos seus interlocutores do cotidiano e de modelos a que tem acesso.

O contato com diferentes modelos de textos, permite que o aluno conheça diferentes estruturas textuais, amplie seu vocabulário e enriqueça sua produção textual, obtendo melhor desempenho na sua competência comunicativa. É importante que primeiro os aprendizes confiem em si, imitando bons modelos para depois colocarem suas próprias idéias com mais segurança. Nessa abordagem, a produção de textos deixa de ser vista como uma atividade mágica, um dom, 
para ser fruto de um trabalho sistemático de aprendizagem, que prevê o papel do professor como mediador desse processo.

Segundo Vygotsky, é possível que os alunos avancem em seus conhecimentos se a escola estiver trabalhando na sua Zona de Desenvolvimento Proximal, ou seja, atuando junto àquilo que o aluno consegue avançar, porém com ajuda. As atividades de reprodução de bons modelos seriam uma ponte entre o que ele já sabe e o que ele não tem condições de apreender sozinho naquele momento.

Porém, como deve atuar esse professor? Há controvérsias sobre como as atividades de cópia de modelos acabam por mecanizar o processo de aprendizagem em detrimento da liberdade de criação. Quais seriam, então, os procedimentos mais adequados para que o contato com bons modelos sirva como uma ferramenta para subsidiar a organização do pensamento dos alunos?

A reprodução de textos pode ser interpretada como uma atividade mecânica. Mas, que outras competências elas ajudariam os alunos a desenvolverem? Qual a sua importância para ajudar os alunos a escreverem de forma mais competente? E como essas estratégias são apresentadas nos livros didáticos, principal ferramenta que norteia o trabalho dos professores em sala de aula?

Acredito que ao abordar de maneira reflexiva a análise e a paráfrase/reprodução de bons modelos, é possível desenvolver um trabalho que ajude o aluno a apropriar-se da escrita de forma cada vez mais autônoma e competente, aprendendo a partir dos textos, não importando seu gênero ou estrutura. Neste sentido, vale a pena debruçar-se sobre as formas como são conduzidas as atividades nos materiais didáticos, uma vez que estes vem sendo utilizados em larga escala na sala de aula como principal ferramenta.

Conhecer boas sequências didáticas que encaminhem as propostas de escrita de forma competente, pode ser uma forma de auxiliar os alunos a constituírem-se enquanto autores, para que possam tornarem-se cada vez mais críticos e participativos em uma sociedade letrada como a nossa. 


\section{Objetivos específicos}

- Analisar a relação entre autonomia e autoridade na produção de textos.

- Verificar como é possível auxiliar os alunos a se libertarem da simples reprodução de modelos para caminhar rumo à sua própria constituição enquanto autores dos seus textos.

- Estabelecer relações entre leitura e escrita nas propostas de produção de textos presentes nos livros didáticos.

- Identificar e analisar diferentes gêneros textuais e os encaminhamentos propostos nos livros didáticos para as atividades de escrita.

- Analisar bons procedimentos que são propostos pelos materiais didáticos para as atividades de escrita.

- Identificar atividades de reprodução e de paráfrase de bons modelos, como ferramentas para ajudar os alunos a escreverem de forma mais competente. 


\section{Metodologia e fontes}

O presente estudo pretende analisar a importância da reprodução de modelos enquanto um importante procedimento para ajudar os alunos a escreverem de forma competente.

Para isso, serão analisadas as concepções teóricas acerca da articulação entre autoria e autoridade como um caminho para a libertação, desenvolvidas principalmente por Hannah Arendt, autora que analisa a questão da autoridade do ponto de vista da educação. George Steiner e Fayga Ostrower são dois dos principais autores que serão utilizados para fundamentar as definições sobre os processos de criação, apresentando idéias que ora se complementam e ora se opõem. Mikhail Bakhtin, um outro autor utilizado, além de atuar como principal teórico representante das idéias acerca dos gêneros textuais, contribui para a temática ao dissertar sobre as influências que nos cercam e nos tornam ecos de diferentes vozes, desenvolvendo conceitos como o da polifonia. Entre outros autores que contribuíram para o desenvolvimento dessa pesquisa, vale ressaltar o papel da mediação na construção do conhecimento desenvolvido por Lev Vygotsky e o conceito de Zona de Desenvolvimento Proximal.

Para ilustrar as idéias desenvolvidas, serão analisadas boas propostas de atividades de escrita presentes em livros didáticos de Língua Portuguesa do $1^{\circ}$ ao $5^{\circ}$ ano do ensino fundamental. Essa análise será feita por amostragem, focando materiais atuais que são adotados nas escolas e que constam do Programa Nacional do Livro Didático. 


\section{FUNDAMENTOS TEÓRICOS}

As idéias de Hannah Arendt alertam sobre como é possível estabelecer relações entre

educação e autoridade. É a partir desse contato com uma autoridade, um modelo, em um processo de coação consentida, que o próprio sujeito acaba construindo sua autonomia. Nesse sentido, George Steiner disserta sobre a idéia de que não existe criatividade no sentido estrito, ou seja, algo absolutamente original, pois estamos a todo momento nos baseando nas idéias de outros. Mikhail Bakhtin também atesta sobre o fato de que o homem tem uma vida marcada pelo social e, em seu conceito sobre polifonia, disserta sobre o quanto o nosso "eu” não é totalmente autônomo; ele existe a partir do diálogo com os outros “eus”. Lev Vygotsky também defende a importância do social na constituição do sujeito, principalmente ao desenvolver suas idéias sobre Zona de Desenvolvimento Proximal: aquilo que uma criança pode fazer com ajuda, fará sozinha amanhã. Portanto, aprender a escrever pode compreender, como uma das etapas deste longo processo, o aprender a parafrasear, ou seja, aprender a usar as próprias palavras para reescrever textos já escritos por outras pessoas. 


\section{Autonomia e autoridade}

A noção de autoridade, no senso comum, muitas vezes vem associada somente a um contexto político. Porém, segundo Hannah Arendt, a autoridade se dá quando o sujeito assume uma responsabilidade pelo mundo no qual está inserido. Nesse sentido, todo exercício de autoridade é uma coação consentida, ou seja, exerce-se a autoridade na medida em que se assume a responsabilidade pelo outro e por si mesmo e esse sujeito não esboça uma reação sobre isso, mesmo que possa fazê-lo, pois aceita essa autoridade com o intuito de aprender com ela.

Essa responsabilidade que se assume perante o outro, vem seguida de uma série de ações conscientes que não têm a intenção de exercer um poder ilimitado sobre as pessoas, ou seja, uma coerção, mas sim de responsabilizar-se, de garantir uma tomada de decisões sobre o outro com a intenção de ajudá-lo a crescer e a viver melhor. No caso da escola, por exemplo, o professor assume a responsabilidade por seus alunos, orientando o ensino e definindo caminhos. Segundo Arendt, essa noção de autoridade seria a base para entender-se a crise que assola a educação: na medida em que a noção de autoridade desaparece, os professores deixam de responsabilizar-se pelos seus alunos e a noção de igualdade que se estabelece acaba por nivelá-los, instaurando-se a crise que vem permeando essas instituições. A escola não pode se abster de seu papel: ela é a porta de entrada da criança para o mundo e o professor acaba sendo essa ponte: cabe a ele representar como o mundo é, responsabilizando-se por instruir os alunos acerca da vida em sociedade. É essa responsabilidade que assume a forma de autoridade. De acordo com ARENDT:

A palavra auctoritas é derivada do verbo augere, "aumentar", e aquilo que autoridade ou os de posse dela constantemente aumentam é a fundação. (2003, p. 164).

Portanto, exercer uma autoridade sobre o outro seria uma forma de contribuir para sua evolução, vindo de alguém que sabe mais para alguém que sabe menos. Porém, vale ressaltar que a autoridade não se trata de algo que deve ser seguido de forma rígida, sem reflexão. Pode ser compreendida muito mais como uma forma de indicar valores, esclarecer formas de se relacionar com a realidade e com aqueles com quem se convive. Aquele que segue uma autoridade não 
assume uma atitude passiva, sem poder de decisão sobre o que está fazendo; trata-se de um reconhecimento dos benefícios e da aprendizagem que se tem a partir de alguém com mais conhecimento. Uma autoridade deve ser alguém que, de alguma forma, precisa ter algo a mais a oferecer, algo que o diferencie do outro, alguém que esteja em outro nível. Por isso, não seguir essa autoridade torna-se algo que acaba por negar nossa própria aprendizagem e o contato com mundo, ou seja, trata-se de reduzir a possibilidade de desvendar os sentidos das coisas que nos cercam.

Um aluno irá reconhecer a autoridade do professor quando percebe nessa "auctoritas" uma experiência boa, que se reflete em uma aprendizagem. Nesse processo, por ser uma coação consentida, a obediência do sujeito confere-lhe também uma certa liberdade, pois oferece-lhe um conhecimento sobre o mundo e uma opção por seguir algo que corresponde ao seu modo de viver e não simplesmente de seguir algo que lhe parece confortável. Essa ação em que um sujeito age sobre o outro, não se dá de forma violenta, mas consentida. Segundo Alexandre KOJÈVE:

A autoridade é a possibilidade que tem um agente de agir sobre os outros (ou sobre um outro), sem que estes outros reajam sobre ele, mesmo sendo capazes de fazê-lo. (2004, p. 58).

No caso, o outro se submete conscientemente, sem se sentir coagido ou agredido. Se partirmos deste pressuposto, podemos considerar que uma pessoa que exerce uma autoridade sobre outra, funcionaria também como alguém que faria o papel de um modelo a ser seguido. Essa autoridade daria as informações e as diretrizes sobre como agir perante o mundo em que vivemos. Um modelo que não destruiria, mas sim legitimaria jeitos de ser e de pensar, auxiliando os aprendizes na tomada de decisões. Essa forma de autoridade, que atuaria como um modelo, estaria fundada na sabedoria, ou seja, na idéia de alguém que tem mais conhecimento sobre o outro e que iria alimentar as ações humanas mais iniciais.

Em um primeiro momento, o indivíduo seguiria essa autoridade de forma consentida e é possível sugerir que exista até uma imitação dessa autoridade. Não se pode confundir essa imitação com uma submissão, pois uma forma de pensar e agir sobre o mundo mais individualizada, só irá se manifestar após um período de contato com bons modelos que apontem caminhos.

De acordo com MACHADO: 
Um estilo pessoal somente pode surgir como resultado de uma submissão temporária, consciente ou não, a algum tipo de coação consentida e a submissão/repetição é vínculo/instrumento de aprendizagem. (2008, p.28).

É a partir deste contato com uma autoridade, um modelo, que o próprio sujeito acaba construindo sua autonomia e adquirindo uma maior liberdade para agir. Ao entrarmos em contato com as autoridades e os modelos que nos instrumentalizam não estaremos sendo condicionados, pois não se trata de um simples reflexo, uma simples cópia, mas de escolhas que se faz de forma consciente. Não é possível compreender a liberdade sem uma ausência total de coação, ou seja, a nossa autonomia nos remete ao contato que temos com as autoridades que nos cercam. Só assim seremos capazes de construir nosso próprio modo de pensar e de agir sobre o mundo.

A partir dessas idéias, o conceito de autoridade estaria também relacionado à idéia de criação, pois seria uma forma de aumentar algo em alguém. Ou seja, manifesta-se como uma responsabilidade que se assume por algo que se inicia em alguém: um projeto, um caminho, uma idéia que se transforma. Trata-se, portanto, de uma ordem inicial de criação.

Aquele que exerce essa autoridade assume responsabilidades e toma iniciativas, porém não extrapola seus limites, garantindo a pessoalidade do próprio sujeito, ou seja, sua própria autonomia e autoria. Uma autoridade como a do professor, por exemplo, deve ter como principal objetivo auxiliar seus alunos a construírem uma consciência crítica. De acordo com MACHADO:

E tal consciência pressupõe um delicado equilíbrio entre, por um lado, a vontade, o desejo, o élan vital de quem busca a originalidade, a pessoalidade, a integridade, a criação, a autoria; e, por outro lado, o respeito pela tradição, pelas normas socialmente acordadas, o acolhimento da autoridade verdadeira, o discernimento na distinção entre o que deve ser preservado e o que deve ser transformado, a humildade no reconhecimento dos limites da consciência. (2008, p.70)

Portanto, autoridade e autonomia, apesar de serem conceitos extremos, guardam uma certa relação entre si: uma relação que prevê a autoria. É este caminho a ser percorrido que garante um meio para se atingir um fim. Não se trata de estabelecer uma relação simétrica, pois a constituição da própria autoria envolve a submissão a uma autoridade, trata-se de planejar ações e não 
simplesmente reagir a elas. Trata-se de uma aposta na natureza humana, na própria constituição do ser enquanto pessoa, enquanto alguém que representa papéis e assume responsabilidades.

Cecília C. Fornazieri, em sua tese de doutorado cujo tema é a relação entre a constituição do sujeito e sua relação com as autoridades que o cercam, disserta sobre como a tradição não pode ser negada e o quanto ela influencia a pessoa para que se torne um sujeito. De acordo com essa autora:

Seguir, contudo, no sentido aqui empregado, não é um fenômeno de massa, um copiar de maneia mecânica, mas uma atitude que exige consciência e livre adesão a algo que se reconhece como maior do que si e a quem vale a pena obedecer. [...] Por isso, pode não ser fácil seguir a um outro, mas é sempre um reconhecimento de bem que é feito a cada passo. Não é um gesto automático, mas uma ação pessoal que exige de modo contínuo a autorização da liberdade em jogo. (2005, p.43-4)

Portanto, basear-se em idéias de outros seria uma forma de mapear um caminho a ser escolhido com base em várias alternativas. Esse leque de opções que se apresentam como modelos a serem seguidos, não tem o objetivo de restringir as ações do sujeito, mas sim de ampliar as suas opções para conseguir realizá-las com maior sucesso. É dessa relação com o meio que o sujeito se constitui e passa a ser autor dos próprios papéis que representa. A partir dessa rede de relações, o sujeito compreende e apreende o outro, construindo a sua própria pessoalidade, conforme assinala FORNAZIERI:

Da conjunção única daquela circunstância com aquele determinado sujeito, nasce a originalidade de um texto. Essa originalidade, portanto, não está fora de seu autor, no estapafúrdio ou inusitado que ele possa inventar, mas em seu caráter único de existir dentro de sua circunstância, na maneira de responder a esse conjunto tão vasto de possibilidades. (2005, p.50)

Portanto, assumir-se como pessoa não é só submeter-se ao outro, mas relacionar-se com ele a fim de emergir sua própria consciência. 
Dessa relação, vale ressaltar um outro aspecto da autoridade exercida pelo professor: cabe a ele atuar de forma a não ultrapassar o limite de decisão que é próprio de cada um. Esta autoridade não pode invadir a autonomia a ponto de destruir a autoria, ou seja, não pode transformar-se em autoritarismo. Cabe a este professor respeitar a própria individualidade de cada um, não comprometendo o núcleo pessoal e a própria integridade de seus alunos, desconsiderando seus pensamentos e idéias. Esse autoritarismo impede que o professor aprecie ou compreenda diferentes pontos de vista.

Ao mesmo tempo, o professor não pode se abster de seu papel enquanto formador ao não assumir a autoridade que lhe cabe. Trata-se de cometer um outro erro, tão grave quanto o anterior: isto é prevaricar, faltar ao cumprimento do dever. Cabe ao professor, responsabilizar-se por seus alunos e conduzi-los por caminhos que contribuam para o seu crescimento. Neste tipo de autoridade não há escolha para o professor: faz parte do seu papel assumir responsabilidades perante seus alunos. Ajudá-os a transformarem-se em seres críticos torna-se o grande desafio para que essa autoridade não se transforme em puro autoritarismo. Trata-se de sugerir um futuro, de incentivar a criação de projetos. Porém, essa autoridade deve manter um equilíbrio para que não atinja a integridade pessoal de seus alunos.

Atualmente em educação muito se tem falado sobre a importância da construção do conhecimento; porém, a discussão vem acirrando-se quando se discute o modo como se constrói esse conhecimento, o papel do professor e o dos alunos nesse processo. A idéia de rede é uma das representações do conhecimento, pois conhecer o significado é estabelecer relações a partir de diversos centros de interesse. De acordo com MACHADO:

Segundo tal ponto de vista, o conhecimento é como uma grande teia, uma grande rede de significações. Os nós são os conceitos, as noções, as idéias, os significados; os fios que compõem os nós são as relações que estabelecemos entre algo - ou um significado que se constrói - e o resto do mundo. (2004, p. 17).

Enquanto a idéia de rede estabelece uma relação com a navegação, com as relações que vão se estabelecendo, posso me perder nessa teia de significados se não tiver um mapa, ou seja, se não estabelecer o que é relevante, tendo em vista o meu projeto. Neste contexto, rede e mapa são idéias que se completam, pois o mapa liga-se à idéia de relevância, ou seja, do que vale mais ou do que 
vale menos em relação ao meu projeto ou às minhas metas. O professor não constrói a rede do aluno, mas é de responsabilidade dele definir o que deve ter nesse mapa, o que deve ser relevante.

Para construir um mapa é preciso definir também o sistema de projeção, ou seja, como foi construído, pois cada mapa expressa um projeto, um ponto de vista e a distorção acaba sendo inerente. Portanto, a competência do professor está associada à capacidade de mapear, de construir mapas de relevância, tendo em vista o projeto de outra pessoa. Esse mapeamento exige por parte do professor uma autoridade, pois é ele que orienta a escolha de percursos para que se possa desfrutar da liberdade da rede sem se perder. Por exemplo, em língua portuguesa, um trabalho com revisão de texto, cujo objetivo é auxiliar os alunos a reescreverem seus textos com base nas intervenções do professor para melhorar sua capacidade comunicativa, não terá êxito se não estabelecer, para o momento, um grau de relevância, ou seja, um foco. Não é possível exigir que um aluno nos primeiros anos do Ensino Fundamental seja capaz de melhorar todos os aspectos referentes à ortografia, à pontuação, à organização das idéias, às características do gênero a que se propõe a escrever etc. Esse equívoco de mapeamento, no que se refere às intervenções do professor, não ajudará esse aluno a avançar; pois, ao definir que deverá melhorar em tudo, no início de um período de aquisição da língua, o professor não estará intervindo em nada, pois esse aluno não será capaz de estabelecer tantas relações. Ao mesmo tempo, se esse professor não mapear nada, ou seja, não interferir em nada ou em muito pouco no texto do aluno, não estará dando nenhum ponto de referência para que esse aluno possa avançar. $\mathrm{O}$ ideal seria estabelecer um foco para a intervenção no trabalho, de modo que esse aluno consiga se concentrar em apenas um dos aspectos (como, por exemplo, garantir que o seu texto contenha as principais características do gênero que foi estudado ou a escrita correta das palavras) para que possa reescrevê-lo da melhor forma para o momento. Vale ressaltar que esse mapeamento das intervenções do professor pode ser diferente dependendo do aluno, da série, do ano, etc, pois está ligado ao projeto de cada um.

Dessa forma, as ações do professor estarão baseando-se nas ações fundamentais de tecer cadeias, redes e significados entre o que o aluno sabe e o que é construído na escola e mapear o que é relevante para não subestimar os alunos ou enchê-los de pormenores. Cabe ao professor a autoridade de mapear, definir relevâncias e articular projetos.

Em contrapartida, de acordo com as idéias desenvolvidas por Machado, no convívio entre professores e alunos ora manifesta-se uma relação assimétrica e ora uma relação simétrica. $\mathrm{Ou}$ seja, estamos a todo momento representando papéis em que ora somos protagonistas e ora somos 
coadjuvantes. Por exemplo, ao mapear as relevâncias do que é interessante desenvolver com os alunos, estamos assumindo que a relação que se estabelece é assimétrica, pois cabe ao professor definir os caminhos que serão percorridos pelos alunos. Já quando ocorre uma mediação por parte do professor junto aos alunos para que estes consigam avançar em seus conhecimentos, a relação que se estabelece é simétrica. $\mathrm{O}$ mesmo ocorre quando o professor exerce sua autoridade, tornando a relação assimétrica ou quando ele pratica a tolerância junto ao outro, em uma relação totalmente simétrica. Não se trata de seguir apenas um caminho, mas de representar um feixe de papéis nos mais diversos âmbitos e nas diferentes relações sociais que se estabelecem entre as pessoas. Segundo MACHADO:

Ao procurar caracterizar a ação do professor, que se desenvolveria em torno do eixo autoridade/tolerância, recorremos a quatro verbos indiciários: mediar, tecer, mapear, fabular. Dois desses verbos representam ações que poderiam, eventualmente, ser classificadas como simétricas, ou ações entre iguais: mediar e tecer; os outros dois, contudo, traduzem ações assimétricas, ordenadas, onde a liderança do professor é absolutamente fundamental: mapear e fabular. (2008, p. 83)

Ao mediar relações e tecer significações trata-se de uma ação comum, em que professor e aluno argumentam. Já ao mapear relevâncias e ao construir narrativas fabulosas não se trata de uma relação entre iguais, uma vez que a responsabilidade do professor é maior na condução das aulas e na orientação dos alunos. Por isso, nos momentos em que o professor exerce sua autoridade é esperado também que ele respeite a vontade e o desejo de seus alunos, incentivando também a busca da originalidade e a construção da autoria. Isso não significa que o sujeito pode desprezar toda uma tradição e transformar tudo ao seu redor. É preciso manter um equilíbrio entre o que é preciso preservar e o que é preciso tornar diferente, reconhecendo as autoridades legítimas ao seu redor e os momentos em que será protagonista ou coadjuvante. É desse equilíbrio que surge a idéia de pessoalidade, ou seja, do modo de ser próprio de cada ser humano. Trata-se de constituir-se como alguém que aprecia diferentes pontos de vista, que assume responsabilidades perante os outros e que se submete a autoridades verdadeiras; porém, permanecendo fiel à sua integridade e aos seus valores. Cabe ao professor, por sua vez, promover o equilíbrio entre autoridade e tolerância. 


\section{Criação e criatividade}

O contato com a autoridade nos possibilita conhecer diferentes modos de atuar perante a sociedade. O ser humano, por ser um ser cultural, imerso em uma cultura, está repleto de marcas que definem o seu modo de ser e influenciam o seu comportamento. Portanto, ao nascer, um bebê já terá contato com muitas informações. Algumas circulam há muito tempo e podem ser consideradas como formas de entrarmos em contato com autoridades que nos cercam, funcionando como modelos para as nossas ações.

George Steiner, um dos maiores críticos literários ocidentais que disserta sobre vários assuntos contemporâneos, dentre eles idéias e concepções sobre criação e criatividade, defende em seu livro Gramáticas da criação, sua obra mais radical, que já não temos começos. Este autor faz uma exploração sobre a criação no pensamento, na literatura, na religião e na história e reflete sobre as diferentes maneiras através das quais falamos de começos. Steiner, filho de imigrantes austríacos, nasceu em Paris, em 1929, morou na Europa e nos Estados Unidos e é autor de uma obra diversificada. Em Gramáticas da Criação, procura demonstrar como estamos a todo o momento "imitando", ou melhor, repetindo modelos, ou seja, ações e idéias de outros. De acordo com o autor, somente Deus, é capaz de produzir algo realmente inovador, algo a partir do nada. Deus seria o verdadeiro combustível, a grande referência, a origem de tudo. Só Deus estaria apto a criar. Segundo STEINER:

Deus só pode se dedicar a criar. Ele é, por auto-definição, le Grand Commenceur. (2003, p.27)

O ser humano, por sua vez, acaba buscando incessantemente esse início de tudo.

Porém, as pessoas também produzem coisas e relacionam-se com a criação, ou seja, com os seus processos de autoria, tanto na literatura, como na música, nas ciências, na matemática etc. Mas, o autor defende que isso não se trata de uma criação, mas de uma recriação, um inventário de algo que já existe. 
Para STEINER, o ser humano só cria a partir de algo que já existe:

\begin{abstract}
Sempre que se discutem modos estéticos de elaboração, o conceito de criação é simultaneamente inevitável e problemático. Uma compreensão rigorosa da mimesis (como na República de Platão) e uma leitura cuidadosa da imitatio (como em certos neoclassicistas e realistas radicais) limitam-se a reconhecer a órbita da "re-criação". [...] O artista "re-conta"; ele estabelece o inventário do existente. Messiaen insistirá que a dinâmica de sua música é uma mera transcrição do canto de pássaros e dos "ruídos" inscritos na natureza física pela Divindade. [...] Talvez a fantasia artística só possa reajustar a composição de certos mosaicos e justapor, por meio de montagens e colagens, o que já se encontrava lá. (2003, p.31-2)
\end{abstract}

Na literatura, por exemplo, é possível observar temas clássicos que são recorrentes e que se repetem ao longo dos tempos, tais como: amor, incesto, morte, inferno. São temas que espelham problemas da humanidade que, mesmo antigos, tornam-se eternos e novos ao mesmo tempo. Na arte, até mesmo correntes como o Surrealismo fazem combinações de formas, materiais ou elementos que já existem.

Há mesmo quem afirme, como Nietzsche em sua teoria sobre O Eterno Retorno, que a história sempre se repete. $\mathrm{O}$ conhecimento avança, mas o que se procura na verdade são as origens. Nos processos de criação ocorreria o mesmo: nenhuma obra é totalmente original, sempre há relações com o passado, baseando-se em prefigurações.

No caso da linguagem, por exemplo, Steiner afirma que é impossível gerar uma linguagem nova, pois seria algo totalmente sem sentido, não compreendido pelos outros. As palavras carregam um sentido, têm uma história e um passado que é a própria etimologia. Nada do que se diz é original, pois as palavras são sempre as mesmas. Para STEINER:

Sempre que se referir à fala comum, toda palavra já terá sido pensada, falada e escrita um milhão de vezes. É essa prioridade e essa circulação que determinam e sobredeterminam seu sentido e seus sentidos. (2003, p.156-7) 
Um bom escritor deve estar sempre em harmonia com a história das palavras, sem se preocupar em criar palavras novas. A criação, estaria muito mais próxima da paráfrase do que daquilo que é visto como novo, como original. Segundo STEINER:

Comunicar [... ] implica oferecer um acesso por meio de uma equivalência ou de uma paráfrase ( mesmo que parcial ), como que num dicionário. (2003, p.160)

No caso da poesia, por exemplo, o uso da palavra inicia-se na repetição, pois as pessoas são convidadas a declamar poemas que apreciam e que sabem de cor. Porém, este ato freqüente de repetição, acaba tornando-se diferente a partir do momento em que o escritor examina essa repetição e usa a palavra de uma maneira pessoal, ao criar seus próprios poemas. Trata-se de uma brincadeira com as palavras, em que a criação não surge a partir do nada, mas sim de algo que já existe. De acordo com STEINER:

O conceito de originalidade em sua essência literal, de originação de novo, seria pouco mais que um devaneio, uma ilusão lisonjeira do sujeito. A realidade, seja como for que a filosofia e as ciências a definam, e o mundo dado, seja num conceito religioso ou materialista de dádiva e preexistência, continuarão sempre como a fonte e o inventário que controlam o imaginário. As lentes da câmera em operação no estético são sem dúvida mais sutis, mais penetrantes e com mais recursos em suas aberturas e seus filtros que as que qualquer ótica poderia conceber. Mas quando nós acreditamos estarmos livres para imaginar, e ainda mais para criar, o que fazemos é simplesmente voltar a tirar fotos. (2003, p.180-1)

Contrapondo essas idéias e, em certo sentido também reafirmando-as, Fayga Ostrower (1920-2001), artista plástica, também disserta sobre a criatividade. Educadora e humanista dedicou sua vida às artes plásticas e à educação artística, mas sua principal contribuição foi a forma como estabeleceu relações entre a arte e a ciência, um tema que a fascinava. $\mathrm{O}$ fato de a história da arte e a história da ciência convergirem em vários períodos era, para Fayga, uma questão lógica, já que ambas as visões compartilham sempre a mesma realidade cultural. Qualquer ruptura nessa esfera 
haveria de ter conseqüências tanto na arte como na ciência. No entanto, ela se empenhou em compreender a reação de cada uma delas às transformações culturais e em entender em que pontos o pensamento artístico e o pensamento científico convergiam e em que pontos divergiam.

Fayga Ostrower chegou ao Rio de Janeiro na década de 30 e cursou Artes Gráficas na Fundação Getúlio Vargas. Produziu obras como gravadora, pintora, desenhista, ilustradora, teórica da arte e professora, tendo como pontos fortes sua visão estética e sua posição ética frente ao mundo.

Em seu livro Criatividade e processos de criação, lançado em 1977, desenvolveu idéias sobre a criatividade e o enfoque que o ser humano dá a esse processo como um ser humano criativo.

Fayga não encara a criatividade como propriedade exclusiva de algumas pessoas com dons especiais, mas sim como potencial próprio da condição do ser humano. A criatividade não é para essa autora um objeto isolado, mas sim um elemento dentro de um contexto, levando-se em conta problemáticas sociais, econômicas, políticas e culturais, que interferem no desenvolvimento da criatividade humana.

É desse modo que Fayga acaba por se aproximar das idéias de Steiner ao afirmar que cada artista só pode criar de dentro para fora, ou seja, falar de experiências vividas em sua própria época. A autora enfatiza que o homem não pode reviver épocas passadas nem antecipar épocas ainda não vividas, mas isto não significa que ele parta de uma tábula rasa. A sua experiência individual, mesmo que historicamente única, se interliga com toda uma linha de evolução humana - quer dizer, só foi possível porque existiram experiências anteriores.

Para Fayga, criar é formar algo novo, é transformar. Trata-se de um pensar específico sobre um fazer concreto, mas a ação do indivíduo é condicionada pelo meio social e os processos de criação acabam sendo compreendidos mais como estados e comportamentos naturais da humanidade.

Essa idéia de criatividade também é desenvolvida por outros autores em vários campos do conhecimento. Abraham Moles, em seu livro A criação científica, aborda termos como a criatividade ou a descoberta, do ponto de vista filosófico e científico. 
Para MOLES, a criatividade pode ser conceituada como:

[...] a aptidão particular do espírito no sentido de rearranjar os elementos do "Campo de consciência" de um modo original e suscetível de permitir operações em um "campo fenomenal" qualquer. (1971. p.59).

Nessa concepção, a idéia de criar estaria mais próxima da idéia de reorganizar; não se trata de criar algo novo, porém, a forma de se organizar as informações é que é nova.

Esse mesmo autor ressalta que para o cientista ou para o artista a sua criação está intimamente ligada à sua concepção de mundo e às relações que estabelece com ele. E, essa concepção de mundo está, por sua vez, influenciada por sua época. Os próprios campos de consciência são conceituados pelo autor como informações que nos vêm de nossa cultura.

Dessa forma, podemos encontrar relações entre os pensamentos de Moles e de Steiner, pois os dois autores ressaltam as influências do mundo ao nosso redor nos momentos de criação e o quanto nos baseamos em algo que já existe para criar algo semelhante.

Para Moles, a originalidade na criação estaria mais associada à forma como nós reorganizamos as informações que temos de acordo com o local ou situação em que nos encontramos. Seria essa interpretação mais individual das informações, as funções mentais mais elementares, anteriores às palavras, as verdadeiras responsáveis pela originalidade das idéias.

No caso da educação, mais especificamente do livro didático, é possível compreender como a criação se manifesta. Os conteúdos que serão desenvolvidos já estariam definidos, a partir de objetivos mais amplos e comuns a todos os anos, séries ou ciclos. Porém, a forma como esses conteúdos seriam apresentados ou desenvolvidos é que sofreria alterações ou rearranjos. De acordo com as idéias de Moles, não se trata de criar conteúdos novos, mas de reorganizá-los, ou seja, a forma de organizá-los é que seria nova.

Essa forma de basear-se em textos ou idéias já existentes e apresentá-las de forma diferente, poderia ser compreendida como a capacidade de parafrasear textos, ou seja, explicar ou interpretar um texto usando outras palavras. Essa forma de expressão da criatividade sofreria grande influência das idéias ao redor, ou seja, da cultura na qual o indivíduo estaria inserido.

Mas, se criar passa a ser parafrasear a partir das influências e informações que nos cercam, é impossível pensar em uma forma nova, diferente? O mesmo ocorre com um pensamento novo: 
como é possível pensar em algo novo se todo pensamento é expresso em palavras baseadas em uma semântica comum?

Sobre isso, Steiner afirma que quando achamos que criamos, na verdade tiramos "uma foto" de algo que já vimos antes. A originalidade não passa de uma ilusão do sujeito, pois toda forma de criação na arte, na música e na literatura estabelece relações com o passado. Essas relações podem ocorrer por imitação, por rejeição, adaptação, paródia, citação etc.

De acordo com a etimologia, a expressão "repetir" significa pedir de novo, porém não se trata de uma simples cópia; parafrasear é na verdade ressignificar. Nessa tarefa há uma certa autoria, não se trata de uma cópia de um modelo, há trabalho dos sujeitos envolvidos nessa tarefa. A ressignificação envolve uma interpretação, não é só uma repetição pura e simples.

A busca pela criação estaria mais próxima da busca de uma transcendência, ou seja, a capacidade de ir um pouco além dos modelos, pois na arte, na literatura e na música os conjuntos temáticos são finitos. De acordo com STEINER:

[...] mesmo o mais intenso e memorável dos produtos estéticos deve sempre ser considerado sob o estatuto do jogo mimético [...] (2003, p.180)

É possível concluir que o que ocorre é o domínio daquilo que é compreensível. Criação, em sua essência, seria algo que não encontra rastros em seu caminho, trata-se de algo divino, só Deus cria a partir do nada. Por mais que os cientistas façam descobertas, os engenheiros tragam novas tecnologias, somos, conforme afirma este autor, somente "hóspedes da criação", pois é impossível falar-se em criação sem que se esbarre no campo do sagrado e em questões que envolvam a fé. A criação humana é sempre mediada por algo que já existe.

George Steiner utiliza-se da palavra gramática no sentido de trazer regras sobre como ocorre esse processo que envolve a criação. Porém, essa palavra é usada no plural, indicando que é possível haver mais de uma perspectiva. Ao usar o plural, Steiner prevê várias abordagens para a criação e não uma única. As comparações que vão estabelecendo-se ao longo do livro Gramáticas da criação entre a matemática, a ciência, a arte, a literatura e a música nos fazem perceber a forte presença do passado. Ou melhor, a presença de modelos que são repetidos.

Vemos essa presença manifestar-se na literatura clássica universal: muitos autores criaram suas histórias baseados em um dos mais importantes livros do passado: a Bíblia. Ana Maria 
Machado em seu livro Como e porque ler os clássicos universais desde cedo, cita vários exemplos de autores que escreveram suas obras a partir de referências a situações bíblicas: José e seus irmãos, de Thomas Mann, Esaú e Jacó, de Machado de Assis, Olhai os lírios do campo, de Erico Veríssimo, O Sol também se levanta, de Ernest Hemingway, entre outros.

Nesse sentido, é possível levantar algumas idéias sobre o papel da escola nesse processo de criação, ou seja, no processo de autoria dos alunos. Como é possível pensar em atividades de escrita que tenham como objetivo ajudar os alunos a produzir textos? Como é possível ajudá-los a avançar nesse processo? Como se pode ensiná-los a ressignificar textos, para que deixem apenas de reproduzir ou copiar textos de outros, a fim de que se libertem de modelos e passem a construir significados, até alcançarem a verdadeira autoria?

Boas propostas de escrita podem auxiliar os alunos a avançarem em seus conhecimentos, tornando-os escritores mais autônomos e competentes.

Mas, é preciso ajudá-los a perceber que a possibilidade de construir "uma certa" autoria se dá quando simplesmente não nos submetemos somente à vontade do outro, ou seja, dos modelos. Para isso, é preciso transcender e se libertar, avançando nos processos de recriação e ressignificação dos textos tidos até então como modelos a serem simplesmente copiados.

Esse seria o grande desafio não só da escola... mas também... da vida! 


\section{Intertextualidade, paráfrase e reprodução}

A fim de compreender melhor as relações que se estabelecem entre os textos que circulam socialmente, visto como modelos pelas pessoas, e os processos de criação e de recriação que se formam a partir dessa relação, um outro aspecto merece ser discutido: a intertextualidade. Trata-se de uma expressão usada para designar a relação dialógica entre os textos, cujas formulações foram desenvolvidas principalmente por Bakhtin, pensador russo, embora outros autores também tenham dissertado sobre esse assunto.

Os textos que são produzidos se relacionam a todo tempo com outros textos já existentes. Portanto, a intertextualidade seria esse diálogo que se estabelece. Toda produção de discursos não surge do nada, se relaciona com os materiais já existentes. A própria palavra, intertextualidade, significa relação entre textos e é inerente à produção humana. O homem sempre se reporta a algo que já foi feito em seu processo de produção. A intertextualidade se dá, pois, tanto na produção como na recepção das informações de que todos tem acesso. Filmes que relembram outros filmes, quadros que se relacionam com outros, propagandas que se utilizam do discurso artístico, poemas escritos com versos de poemas clássicos, tudo isso são textos em diálogo com outros textos: intertextualidade. Todo texto acaba sendo uma construção a partir da transformação de outro.

Essa relação que se estabelece entre os textos, reafirma a idéia de que o autor sofre influências em sua formação: ele cresce e amadurece no contato com outros autores. Trata-se de uma troca entre as pessoas para a construção do próprio diálogo.

A partir dessas influências, surge uma série de gêneros com o objetivo de esclarecer as relações que se estabelecem entre os textos, seja por meio de aproximações ou de distanciamentos. Entre eles, podemos citar a paródia, a reprodução e a paráfrase.

A produção de paródias inclui textos que se caracterizam como uma segunda voz de um outro texto, em oposição a ele. Segundo Samir MESERANI, em seu livro O intertexto escolar:

Etimologicamente para-ode significa um canto paralelo, um contracanto, que se opõe ao original, parodiado. Bakhtin, como Tynianov, ao confrontar paródia e estilização, mostra que essa também se faz como uma segunda voz 
de um outro texto, estilizado, mas de modo convergente, concordante, enquanto a paródia é divergente, discordante. (1995, p.69).

A paródia é um gênero marcado pelo seu caráter contestador, típico da literatura moderna.

Enquanto a paródia seria uma forma mais distante de se relacionar com os textos, por apresentar idéias contraditórias ao texto original, a reprodução seria uma forma de se estabelecer uma relação mais direta com os textos, pois trata-se da produção idêntica ou muito semelhante a algo já escrito. Segundo MESERANI:

Reprodução é uma expressão usada para indicar um ato ou produto que mantém igualdade com outro ato ou produto que lhe serve de original. Tratase, pois, da produção do mesmo, do idêntico ou muito semelhante. (1995, p.81).

Nesse caso, a reprodução seria algo bem próximo à cópia, à transcrição. Pode ser exemplificada por meio da imitação ou das citações, em que um trecho de outro texto serve para ilustrar ou complementar uma informação. Não seria exatamente uma forma de se estabelecer uma relação mais criativa entre os textos, pois não há uma transformação do texto original, uma assimilação; mas sim algo que confirma ou exemplifica. Dessa forma uma reprodução implica em não realizar nenhum tipo de alteração no texto citado e geralmente aparece de alguma forma destacada, entre aspas, por exemplo.

O caráter da reprodução não se aplica ao texto literário, pois a cópia não seria interessante e poderia caracterizar-se como plágio. Já o aproveitamento de trechos ou idéias não seria mais uma reprodução, mas uma forma de se apropriar do texto, reelaborando-o ou recriando-o.

A reprodução teria sua função mais centrada em contextos escolares, cujo objetivo é reproduzir algo para demonstrar que se compreendeu uma informação, mantendo as idéias sem alterá-las.

Já a paráfrase seria uma outra forma de se estabelecer relações entre os textos: trata-se de dizer a mesma coisa, porém com outras palavras. A paráfrase sempre se remete a um outro texto para reafirmá-lo ou esclarecê-lo. A atividade pode ocorrer de duas formas: a paráfrase explicativa e a paráfrase imitativa, ou seja, uma forma de reformular o texto original de modo mais reprodutivo e outro de modo mais criativo. 
Uma forma de realizar a paráfrase que inclui a transformação de um texto em que a principal atividade é a substituição de alguns termos ou a explicação de outros, seria a paráfrase explicativa. Já a imitativa, pressupõe uma capacidade de utilizar os diferentes recursos utilizados por vários autores para escrever um novo texto. Em sua tese de mestrado intitulada Paráfrase, autoria e processos de assimilação da palavra do outro, Maria José Nóbrega conceitua essas duas formas de reformular um texto:

A reformulação explicativa, como a explicação de um texto-fonte feita por um especialista dirigida a um público leigo, supõe que no processo de transformação do texto-fonte para o novo texto haja substituição de termos técnicos por outros mais familiares; maior clareza com a eliminação de eventuais ambigüidades ou de passagens implícitas etc. $\mathrm{O}$ texto produzido responde a uma relação não-simétrica entre os interlocutores e pode assumir a forma de uma ampliação ou de uma condensação, como nos resumos, por exemplo.

A reformulação imitativa pode permitir que se aprenda a lidar com a diversidade dos recursos expressivos (a capacidade de parafrasear é um dos testes clássicos de proficiência em língua), considerando as diferenças semânticas entre as diversas possibilidades em função da situação comunicativa. A atividade permite tanto ampliar, quantitativamente, o repertório expressivo como melhorar, qualitativamente, o ajuste das possibilidades a um contexto específico. Entretanto ao se redigir o novo texto, não são apenas as características do texto-fonte que se mantêm, também se introduzem nele as marcas de seu autor. A reformulação imitativa pode constituir o pastiche, em que, com finalidades lúdicas, se imita um texto-fonte ou a paródia em que se imprime, normalmente, uma intenção cômica ou satírica. [...] A atividade de paráfrase oscila entre a reformulação explicativa e a imitativa. (2000, p.17)

Portanto, podemos concluir que a paráfrase explicativa acaba traduzindo um outro texto de forma quase literal. Seria uma forma de substituir por meio de sinônimos, cortes ou ampliações algo que já foi dito antes. Já a paráfrase criativa prevê que o novo texto se expanda e ganhe novos significados. Não se trata de uma negação do texto-fonte, discordando dele como na paródia, mas 
de ultrapassar os limites da simples substituição de termos e promover aproximações com o textofonte por meio do tema, do estilo, da estrutura de um gênero etc. Trata-se de reformular um texto de forma que seja possível construir novos sentidos. Dessa forma, há avanços nessa produção, pois não se trata apenas de uma reprodução idêntica.

Portanto, uma proposta de produção de textos por mais "criativa" e inédita que seja, não deve negar ou abandonar os textos que lhe foram apresentados como modelos de escrita. Muito pelo contrário, é importante estabelecer relações entre eles, interpretando-os e produzindo paráfrases de acordo com a sua própria construção de sentido.

Para ilustrar essa idéia, é possível recorrer à literatura. Jorge Luis Borges, por exemplo, foi um escritor, poeta, tradutor, crítico e ensaísta argentino mundialmente conhecido por seus contos e histórias curtas dentre as quais podemos destacar Biblioteca de Babel, que se encontra no livro Ficções, publicada pela editora Globo, em 1995. Neste conto, o autor faz uma comparação entre o universo e uma biblioteca e, assim como os livros seriam grandes combinações entre as letras, o mundo também seria uma grande combinação de coisas. Nesse sentido, o mundo seria constituído por uma biblioteca infindável, abrigando uma infinidade de livros, portanto contendo todas as possibilidades da realidade. Alguns não fazem o menor sentido, ou o fazem numa língua há muito desconhecida. Outros são meras repetições de uma mesma palavra. Busca-se incessantemente alguém que saiba decifrar as mensagens contidas nos misteriosos volumes, que seria o correspondente a um deus.

Entre as várias interpretações possíveis do conto de Jorge Luis Borges, uma dá conta que se trata de uma grande metáfora em que mundo e literatura se confundem. Ler um texto é tentar decifrá-lo, mas se considerarmos que o próprio mundo está impregnado de linguagem, a própria realidade pode ser considerada como uma grande biblioteca cheia de textos à espera de quem os decifre.

Nesse conto é possível observar a idéia de infinito, de algo que não tem fim e de como é possível propor uma diversidade de combinatórias entre as coisas usando praticamente os mesmos elementos. Esse fato também é possível de ser observado nas situações que envolvem uma criação, ou melhor, uma recriação de textos. As formas que delimitam o que e o como escrever já estão presentes em vários modelos que circulam socialmente, cabendo ao autor recombiná-las a seu modo, em que é possível observar infinitas possibilidades diferentes. 
Há vários artigos que utilizam a idéia dessa Biblioteca para ilustrar suas idéias: em um deles, publicado pela Revista Ciência Hoje em 12 de maio de 2006, há uma comparação entre a obra de Borges e os estudos sobre genética, em especial, os genomas. O autor destaca que todos os seres vivos são formados por uma combinação de genes, assim como todas os livros de uma biblioteca são formados por uma combinação de letras. Um outro artigo compara a biblioteca de Borges com a web e a sociedade em rede, em que todas as informações se interligam e se completam.

As idéias contidas nesse conto dissertam sobre o fato de que todos os livros que já foram escritos e todos que ainda o serão, já se encontram nessa biblioteca. Tudo já estaria criado, bastaria apenas conseguir localizar.

Devido à beleza do conto Biblioteca de Babel e o valor literário de seu autor, Jorge Luis Borges, a transcrição do conto encontra-se em anexo para melhor ilustrar a idéia de criação, enquanto uma grande recombinação de elementos. 


\section{Interação e aprendizagem}

Retomando as idéias de Steiner de que tudo o que criamos surge a partir de algo que já existe, seja por meio da recriação ou da paráfrase, devemos considerar que, ao criar, estamos a todo tempo sendo influenciados pelas idéias de outros. Ou seja, aprendemos com o outro, por meio da interação. Essas idéias nos possibilita abordar as teorias desenvolvidas por Vygotsky, teórico russo que desenvolveu estudos sobre a história do comportamento.

Ao propor um estudo sobre o desenvolvimento humano e seus processos intelectuais, Vygotsky aborda o percurso do indivíduo ao longo da vida em relação ao seu desenvolvimento biológico. Parte de um estudo sobre a filogênese, comparando o homem com o animal, disserta sobre a sociogênese, comparando grupos sociais e propõe um estudo sobre a ontogênese, avaliando o percurso do indivíduo ao longo da vida, ou seja, uma criança e um adulto imersos em uma mesma cultura.

Comparando símios, homens primitivos e crianças, Vygotsky disserta sobre o desenvolvimento filogenético, ou seja, sobre a origem, a gênese da espécie. Segundo ele, esse desenvolvimento teria estágios semelhantes em todos os animais.

O primeiro estágio estaria relacionado com as reações hereditárias ou modos inatos de comportamento, mais conhecido como instinto. Sua função está ligada principalmente à sobrevivência. Todos os animais já nascem com reações que são instintivas, desde os mais desenvolvidos, como os homens, aos mais simples, como as aranhas.

O segundo estágio seria o estágio dos reflexos condicionados, cujo treino seria o responsável por desenvolver a aprendizagem. Seres humanos em início de desenvolvimento podem ser treinados, assim como cães, conforme demonstraram os experimentos de Pavlov.

O terceiro estágio seria a manifestação de desenvolvimento que mais aproximaria os macacos antropóides dos seres humanos: o comportamento racional, que envolveria as reações intelectuais.

O uso de instrumentos para alcançar objetos e a oposição do polegar nas mãos, fato que permite uma melhor preensão das coisas, tornam-se traços que afastam o macaco de outros animais que apenas respondem por meio de condicionamentos. Essas características aproximam o macaco 
do homem, assim como o fato de conseguirem generalizar um comportamento em situações em que são desafiados, comprovando que começam a usar o intelecto.

A grande diferença seria a capacidade que o ser humano possui ao utilizar a linguagem para se comunicar a serviço da execução de alguma tarefa, ou seja, para a realização de um trabalho. Nos macacos, o uso de signos de forma controlada não aparece.

A linguagem, entre os seres humanos, é universal, pois trata-se de uma representação simbólica, fruto de uma construção social e cultural.

A primeira função da linguagem é a comunicação entre as pessoas, porém, para Vygotsky, ela também é usada como um instrumento do pensamento. A relação entre pensamento e palavra é um processo, um movimento contínuo de vai e vem entre palavra e pensamento... e os mesmos sofrem alterações.

Podemos concluir a partir desses pressupostos, que todas as frases que proferimos na vida real possuem uma espécie de subtexto, um pensamento oculto por detrás delas, que surge e se desenvolve a partir da interação entre as pessoas. O desenvolvimento da linguagem é inicialmente social, depois egocêntrico e finalmente interiorizado. Ao se internalizarem, os signos transformamse em instrumentos subjetivos que dirigem e regulam a conduta e o pensamento. Assim, inicialmente, a regulação da conduta é externa, depois é interpessoal e, finalmente, intrapessoal.

Esse processo de interação com o outro existe desde o nascimento, embora não ocorra de forma voluntária no começo. Em um primeiro momento a criança, ao nascer, apenas responde a estímulos e, embora a interação já esteja presente, um bebê não consegue interagir voluntariamente com o mundo. A percepção é vista como um processo natural, submetido a leis universais. Trata-se de uma sensação, característica do aparato perceptual.

Com o passar do tempo e o contato com outras pessoas, essa percepção começa a se alterar por ser um processo mediado pelo social, ou seja, pela relação entre as pessoas e com o mundo.

Um outro traço do desenvolvimento do pensamento, de acordo com Vygotsky, é o processo de aquisição e domínio de instrumentos para demonstrar uma seqüência de pensamentos organizados. Esse processo de mediação modifica os esquemas cognitivos e, portanto, sua relação com o meio. Aos poucos a criança vai dominando esse objeto e utilizando-se dele para se relacionar com o mundo.

As alterações da memória da criança ao adulto também pode caracterizar esse processo de desenvolvimento. Enquanto uma criança menor precisa manipular certos objetos para conseguir 
memorizar, crianças maiores que já frequentam escolas ou se relacionam com mais pessoas por mais tempo, já conseguem criar um método de notação para ajudá-las a lembrar-se das coisas.

Dessa forma, é possível perceber que o processo de memória imediata torna-se um processo de memória apoiado na notação para ajudar na memorização das coisas.

Podemos concluir que há uma passagem de um pensamento mais concreto para um pensamento mais categorial, em que a escola assume um papel importante: o espaço da escrita. Torna-se o local para vivenciar conhecimentos e auxiliar no desenvolvimento do conhecimento.

Nesse sentido, o papel do professor e, por consequência, do livro didático, passa a ser visto como uma importante ferramenta para garantir o acesso ao conhecimento e a interação necessária para que todos possam avançar em seus processos. Todos esses esquemas são alimentados a partir das experiências prévias do sujeito e do contexto no qual está inserido: somos influenciados pela dimensão contextual a todo momento.

Ao analisar as idéias de Vygotsky, nas quais o desenvolvimento da criança inicia-se com percepções mais primitivas e, aos poucos, de acordo com influências principalmente culturais, vai alterando-se e sofrendo adaptações, é possível concluir que as mudanças no desenvolvimento começam no biológico, mas terminam no cultural, ou seja, no contato com seus pares e na entrada à escola.

Porém, esse desenvolvimento será diferenciado de acordo com a história pessoal de cada um. Na medida em que o indivíduo sofre diferentes influências culturais poderá reagir de formas diversas, tornando-se muito desenvolvidas em alguns, enquanto que em outros sejam insipientes.

Por esse motivo, embora algumas etapas no desenvolvimento sejam definidas como padrões que se repetem, muito ligadas ao desenvolvimento biológico, como a infância, a juventude, a idade adulta e a velhice, há formas diferentes de reagir a essas etapas, muito mais ligadas ao desenvolvimento cultural dos sujeitos.

Cada sujeito irá transformar o seu presente ou recriar o seu passado a partir de julgamentos de valor que para ele são significativos, consciente ou inconscientemente. Essa valoração não é individual e solitária, mas pautada por uma inserção social desse sujeito no seu meio e das influências que exercem sobre ele.

Portanto, estudar o desenvolvimento humano apenas do ponto de vista maturacional é estudar um sujeito a-histórico, que não representa a sua totalidade. Se cada sujeito tem vidas 
diferentes, inserções sociais diferentes, como é possível definir as etapas de desenvolvimento como algo estanque e igual para todos?

Não é possível afirmar que há uma verdade absoluta sobre a influência da escolarização na vida das pessoas, mas é possível concluir que essa influência pode se dar pelo relacionamento entre as pessoas. Portanto, o funcionamento cognitivo humano estaria muito mais ligado à idéia de interação do que à idéia de escolarização.

Nesse sentido, o livro didático seria uma das formas de garantir essa interação, ao propor atividades e encaminhamentos que levariam os alunos a se relacionarem com as pessoas à sua volta. Já que é por intermédio dos outros que as relações entre sujeito e objeto são estabelecidas, o livro didático também poderia ser considerado objeto dessa relação.

Nessa perspectiva sóciointeracionista, o conhecimento se dá pelas interações com o outro e com todo o contexto ao seu redor. São processos de interlocução em que os sujeitos modificam-se no próprio processo de construção do conhecimento.

Esse pressuposto nos leva à idéia de Zona de Desenvolvimento Proximal (ZDP). Segundo REGO:

Vygotsky identifica dois níveis de desenvolvimento. O primeiro, que ele chamou de real ou efetivo, refere-se àquelas conquistas já consolidadas na criança, funções ou capacidades que ela já aprendeu e domina, sem precisar mais da assistência de alguém mais experiente da cultura. Indica, assim, processos mentais que já se estabeleceram, ciclos de desenvolvimento que já se completaram. O outro nível é o de desenvolvimento potencial, que se relaciona com as capacidades em vias de serem construídas. Este nível também se refere àquilo que a criança é capaz de fazer, só que mediante ajuda. Nesse caso, a criança realiza tarefas e soluciona problemas por meio do diálogo, da colaboração, da imitação, da experiência compartilhada e das informações e pistas que lhe são oferecidas.

A distância entre aquilo que a criança é capaz de fazer de modo autônomo (nível de desenvolvimento real) e aquilo que ela realiza em colaboração (nível de desenvolvimento potencial) caracteriza a zona de desenvolvimento proximal, porque, em interação com outras pessoas, a criança é capaz de colocar em movimento vários processos de desenvolvimento que, sem a ajuda externa, seriam impossíveis de ocorrer. Esses processos se internalizam 
e passam a fazer parte das aquisições de seu desenvolvimento individual. É por essa razão que "aquilo que é zona de desenvolvimento proximal hoje será o nível de desenvolvimento real amanhã - ou seja, aquilo que uma criança pode fazer com assistência hoje, ela será capaz de fazer sozinha amanhã." (VYGOTSKY, 1984, p.98). (2003, p. 28-9)

Dessa forma, ao considerarmos os processos de desenvolvimento das crianças é preciso levar em conta não só sua Zona de Desenvolvimento Real, ou seja, o que consegue fazer sozinha, mas também sua Zona de Desenvolvimento Potencial, aquilo que consegue fazer com ajuda por meio de instruções, demonstrações, pistas, observação de modelos etc. De acordo com OLIVEIRA:

\begin{abstract}
A Zona de Desenvolvimento Proximal refere-se, assim, ao caminho que o indivíduo vai percorrer para desenvolver funções que estão em processo de amadurecimento e que se tornarão funções consolidadas, estabelecidas no seu nível de desenvolvimento real. (1993, p.60)
\end{abstract}

Portanto, no processo de ensino-aprendizagem deve-se ter como início o nível de desenvolvimento real das crianças e, por meio de intervenções pedagógicas, feitas pelo professor ou pelo livro didático, é possível fazer com que avancem em seus processos. Esses avanços podem ocorrer por imitação de modelos, pois os indivíduos estão a todo o momento recriando a própria cultura. Para Vygotsky, esse mecanismo de imitação não seria a simples cópia de um modelo, mas uma reconstrução de tudo o que é observado nas pessoas que estão ao seu redor. Para a criança é possível criar algo novo a partir do que observa no outro.

\title{
Segundo OLIVEIRA:
}

Vygotsky não toma a atividade imitativa, portanto, como um processo mecânico, mas sim como uma oportunidade de a criança realizar ações que estão além de suas capacidades, o que contribuiria para o seu desenvolvimento. Ao imitar a escrita do adulto, por exemplo, a criança está 
promovendo o amadurecimento de processos de desenvolvimento que a levarão ao aprendizado da escrita. (1993, p.63)

Não se trata de uma postura tradicional ou diretiva, mas sim de uma imitação muito mais próxima da recriação de modelos. Esta imitação se dá por meio da interação que o indivíduo estabelece com as informações que estão ao seu redor: aprende-se em um primeiro momento imitando os comportamentos de outros. Assim, não é possível tratar os processos de imitação como sendo algo puramente mecânico. Reproduzir é sempre dizer outra coisa do ponto de vista discursivo, pois para VYGOTSKY:

[...] uma pessoa só consegue imitar aquilo que está no seu nível de desenvolvimento [...] (1984, p.114).

Nesse sentido a interação torna-se a base para o processo de aprendizagem e, portanto, é preciso que as intervenções sejam planejadas de forma a atuarem na Zona de Desenvolvimento Proximal dos alunos, para que possam realmente recriar a partir do que já sabem e avançar em seus processos. A forma como os indivíduos irão ressignificar os dados, a partir da sua própria percepção, prevê a capacidade de inferir a partir de dados que já possui.

Para Vygotsky, portanto, a aprendizagem é construída socialmente, com base na interação. Nessa concepção, a aprendizagem envolve a observação, a mediação e a reconstrução pessoal do indivíduo para que internalize esses conhecimentos.

Assim, como o desenvolvimento de um conhecimento se remete à interação com outras pessoas, compreende-se o mundo ao redor e alcançam-se avanços construindo-se paráfrases, emitindo comentários, resumos, acréscimos e supressões em textos produzidos pelas pessoas ao seu redor. Trata-se de repetir a palavra do outro, de uma forma diferente, até torná-la a palavra do próprio sujeito. 


\section{Gêneros discursivos e produção de textos}

Pode-se associar as concepções acerca da influência do outro ao estudo de Bakhtin sobre a inerente polifonia da linguagem, na medida em que todo discurso é composto de outros discursos e toda fala é habitada por vozes diversas.

Mikhail BAKHTIN, pensador russo, defende que quem escreve propõe um diálogo e espera ser ouvido e respondido, mesmo que seja para ele mesmo. Por esse motivo, fora de uma sociedade, o homem não teria existência. Todos têm uma vivência marcada pelo social e pela história, vinculando sua vida à cultura. Para este autor, o que importa considerar é a constante perspectiva dialética:

Na realidade, o ato de fala, ou mais exatamente, seu produto, a enunciação, não pode de forma alguma ser considerado como individual no sentido estrito do termo; não pode ser explicado a partir das condições psicofisiológicas do sujeito falante. A enunciação é de natureza social.” (1986, p. 109)

Segundo Bakhtin, a enunciação se dá devido à interação verbal, mediada pelo social. Assim, todo enunciado é um diálogo, uma relação entre as pessoas. Essa concepção dialética de linguagem pressupõe enunciados antecedentes e enunciados que o sucederão. Para este autor:

A palavra é uma espécie de ponte lançada entre mim e os outros. Se ela se apóia sobre mim numa extremidade, na outra, apóia-se sobre meu interlocutor. (1986, p. 113)

A partir do momento em que um enunciado é proposto, o ouvinte torna-se um locutor, o que exige dele uma atitude responsiva ativa. Dessa forma, quem ouve um enunciado responde a seu modo: concorda, discorda, completa, adapta etc; dessa forma, quem ouve está em processo de elaboração constante, ou seja em um eterno devir.

A base da interação humana está relacionada com o uso da língua, que acaba materializando-se em forma de enunciados orais e escritos. Esses enunciados são formados por um conteúdo temático, por um estilo e por uma construção composicional, que variam de acordo com 
as intenções de comunicação e são chamados de gêneros do discurso. Bakhtin foi o primeiro a empregar a palavra gêneros com um sentido mais amplo, referindo-se também aos textos que utilizamos nas situações cotidianas de comunicação.

Baseados nos pressupostos teóricos de Bakhtin, os Parâmetros Curriculares Nacionais de Lingua Portuguesa fazem as seguintes considerações:

Todo texto se organiza dentro de um determinado gênero. Os vários gêneros existentes, por sua vez, constituem formas relativamente estáveis de enunciados, disponíveis na cultura, caracterizados por três elementos: o tema, a forma composicional (estrutura) e o estilo (marcas lingüísticas). Pode-se ainda afirmar que a noção de gêneros refere-se a 'famílias' de textos que compartilham algumas características comuns, embora heterogêneas, como visão geral da ação à qual o texto se articula, tipo de suporte comunicativo, extensão, grau de literariedade, por exemplo, existindo em número quase ilimitado. (2000, p. 26)

Numa situação de interação verbal, a escolha do gênero não é completamente espontânea, pois considera um conjunto de regras dadas pela própria situação de comunicação: quem fala, sobre o que fala, com quem fala, com qual finalidade. Todos esses elementos condicionam as escolhas do locutor, que, tendo ou não consciência, acaba por fazer uso do gênero mais adequado àquela situação.

Ao se abordar o ensino de produção de texto, o primeiro aspecto que cabe destacar é o da variedade de textos. Este objeto de aprendizagem não é um objeto único, mas uma pluralidade de gêneros textuais que apresentam, cada um deles, características lingüísticas bem precisas. Devemos enfocar o ensino da produção de textos não como um procedimento único e global, válido para qualquer texto, mas como um conjunto de aprendizagens específicas de escrever; aprende-se a narrar, a explicar, a expor, a argumentar, a descrever, a redigir atas, a escrever diversos tipos de cartas etc. Cada texto apresenta problemas de escrituras distintos que exigem a adoção de estratégias de ensino diferenciadas e adaptadas a eles.

O aluno deve tomar consciência da diversidade textual e aprender a escrever textos em função das situações particulares de comunicação (segundo o objetivo que se pretenda atingir: convencer, divertir, explicar; segundo seu destinatário: autoridades, colegas de classe, professores, 
pais, alunos de outra escola; segundo o lugar social onde o texto sairá publicado: revista ou jornal da escola, fichamentos para uso em aula etc.) e, para isso, terá de inspirar-se em ter como referência outros textos sociais em uso.

É obrigação da escola oferecer ao aluno vivências significativas com a língua para que ele possa interagir na sociedade de forma competente, exercendo a cidadania, direito indiscutível de todos.

O trabalho com o livro didático deve proporcionar o desenvolvimento da capacidade leitora e escritora junto aos alunos. Durante o ano, os textos analisados devem contemplar os mais variados gêneros discursivos para que os alunos entrem em contato com as várias tipologias textuais que circulam socialmente, enriquecendo seu vocabulário e seu conhecimento de mundo. Dessa forma, estarão se apropriando de formas de escrever, ou seja, de modelos de escrita, para que a partir deles possam recriar e construir o seu próprio texto. Dessa idéia surge o conceito de polifonia, proposto por Bakhtin: em linguística, polifonia é a presença de outros textos dentro de um texto, causada pela inserção do autor num contexto que já inclui previamente textos anteriores que lhe inspiram ou influenciam. A polifonia é um fenômeno também identificado como heterogeneidade enunciativa, que pode ser mostrada (no caso de citações de outros autores em obras acadêmicas, por exemplo) ou constitutiva (como a influência de dramaturgos clássicos em Shakespeare, que não é mencionada diretamente, mas transparecida). Neste sentido, podemos supor que Bakhtin, ao propor o conceito de polifonia, parece aproximar suas idéias daquelas desenvolvidas por Steiner. Ao nos comunicarmos, lermos ou criarmos um texto, estamos sempre nos remetendo a algo que já foi escrito ou falado por alguém; a criação não existe do nada, somos eco das vozes de outras pessoas. Sobre esse assunto, sinalizam os $P C N$ :

A produção de discursos não aparece no vazio. Ao contrário, todo discurso se relaciona, de alguma forma, com os que já foram produzidos. Ness sentido, os textos, como resultantes da atividade discursiva, estão em constante e contínua relação uns com os outros. A esta relação entre o texto produzido e os outros textos é que se tem chamado intertextualidade. $(2000$, p.26)

Porém, isso não quer dizer que a linguagem é desinteressada ou repetível. Embora exista uma unificação da linguagem influenciada por aspectos históricos e sociais, para Bakhtin cada palavra é no mínimo duas palavras, e cada evento da linguagem é a atualização de uma relação de 
forças entre sujeitos históricos distintos. São vozes distintas presentes em um mesmo sujeito que recria a partir de modelos com os quais vai entrando em contato ao longo da vida. A partir desse pressuposto surge a noção de "estilo": o que tradicionalmente se vê como a expressão individual, Bakhtin vai entender como a forma pela qual se relacionam as diferentes linguagens, ou seja, como os sujeitos se apropriam das linguagens constituídas histórica e socialmente para compor o seu próprio jeito de escrever. Dessa relação dialógica que prevê as vozes de autores anteriores, surge a voz do próprio sujeito da enunciação.

Aos poucos, o sujeito modifica seu discurso em função das intervenções dos outros discursos com os quais têm contato, ou seja, se apropria de sentidos que já foram construídos por outros. O eu, para Bakhtin, não é totalmente autônomo; ele existe a partir do diálogo com os outros eus; necessita da colaboração de outros para poder constituir-se "autor" de si mesmo. Há uma apropriação da palavra do outro para se transformar na palavra do próprio sujeito. Assim como as suas idéias irão influenciar as idéias de outras pessoas.

E, nessa relação dialógica, convivem vozes diferentes, mas em pé de igualdade. 


\section{ASPECTOS DIDÁTICOS E METODOLÓGICOS}

Os livros didáticos vêm sendo utilizados nas escolas como um dos aliados do professor para desenvolver a aprendizagem. Nesse sentido, a expectativa é a de que estejam de acordo com as novas concepções sobre o ensino de língua portuguesa, cujo principal objetivo é a ação sobre o objeto de ensino, mediada pela interação com o outro. A relação entre a prática de leitura e a de produção de textos deve ser objeto de reflexão constante, suscitando reflexões sobre como escrever a partir de bons modelos. As atividades de escrita devem conter propostas de natureza distintas, porém é importante garantir a presença de paráfrases, pois aprende-se a escrever a partir das idéias do outro, assimilando-as e reformulando-as para que se possa, aos poucos, alcançar um verdadeiro processo de autoria. 


\section{O livro didático e a educação}

Durante esta análise teórica, foi possível destacar a importância da autoridade, como um modelo a ser seguido para ajudar os indivíduos a crescerem e a viverem melhor. Foi possível destacar, por meio das idéias de Arendt, que a partir deste contato com uma autoridade, um modelo, é que o próprio sujeito acaba construindo sua autonomia e adquirindo uma maior liberdade para agir. Ao entrarmos em contato com as autoridades e os modelos que nos instrumentalizam não estaremos sendo condicionados, pois não se trata de um simples reflexo, uma simples cópia, mas de escolhas que se faz de forma consciente. Neste contexto, considero que, em educação, além do professor tornar-se uma autoridade e um modelo para seus alunos, o livro didático também poderia cumprir esse papel. Junto com o professor, o livro didático assumiria a responsabilidade pelos alunos e pelos caminhos pelos quais é possível construir a própria autonomia.

A idéia da importância de um modelo para a construção da autonomia, nos leva ao conceito de criação desenvolvido por Steiner. Segundo este autor, a criação se manifesta por meio de uma recriação, um inventário de algo que já existe. Novamente entre os modelos que influenciariam a formação dos alunos encontramos o livro didático, apresentando modelos de escrita e ajudando os alunos a melhor interpretá-los, para que possam se apropriar das diferentes formas de escrever.

Neste sentido, os textos que são produzidos se relacionam a todo tempo com outros textos já existentes. Surge, portanto, a idéia de que toda produção de discursos não surge do nada, se relaciona com os materiais já existentes. A intertextualidade seria esse diálogo que se estabelece entre eles, cujas idéias, desenvolvidas por Bakhtin, se baseiam no conceito de polifonia, ou seja, somos vozes que se baseiam em idéias e vozes de outrem.

É por meio dessa interação com o outro e com o mundo ao seu redor que o sujeito reinterpreta as informações que recebe e compartilha seus conhecimentos de mundo com seus pares. Compreender a fala do outro e fazer-se compreender pelo outro tem a forma do diálogo. Assim, o sujeito pode avançar em seus conhecimentos quando for capaz de colocar em movimento vários processos de desenvolvimento que, sem a ajuda externa, seriam mais difíceis de ocorrer, de acordo com a teoria socioconstrutivista desenvolvida por Vygotsky. 
A interação é um forte componente no desenvolvimento da escrita e um professor que se responsabiliza pelo processo de desenvolvimento dos seus alunos, irá organizar essas atividades por meio de sequências didáticas. A fim de melhor direcionar esse ensino, muitas vezes, acaba utilizando o livro didático como um caminho a ser seguido. Mais uma vez esse material ocupa um lugar importante na formação dos alunos: funciona como um elo entre o que aluno sabe e aquilo que poderá vir a aprender.

O hábito de os professores consultarem impressos que representam práticas docentes existe há muito tempo. No Brasil, os primeiros manuais com concepções e práticas pedagógicas eram traduções de manuais europeus, principalmente os franceses. Circe BITTENCOURT, professora doutora da Faculdade de Educação da Universidade de São Paulo, que há anos vem se dedicando ao estudo do livro didático, aponta como esse veículo foi merecendo a atenção de escritores brasileiros, ainda no período colonial:

Quem foram, então, os pioneiros da produção didática brasileira?

Considerando o período entre 1810 e 1910, pode-se verificar uma mudança no perfil dos autores. Um primeiro grupo iniciou sua produção a partir da chegada da família real portuguesa no Brasil, e suas obras foram produzidas pela Impressão Régia, mas podemos identificar uma primeira "geração" a partir de 1827, autores preocupados com a organização dos cursos secundários e superiores, apenas esboçando algumas contribuições para o ensino de "primeiras letras". Uma segunda "geração" começou a se delinear em torno dos anos 1880, quando as transformações da política liberal e o tema do nacionalismo se impuseram, gerando discussões sobre a necessidade da disseminação do saber escolar para outros setores da sociedade, ampliando e reformulando o conceito de "cidadão brasileiro", criando-se uma literatura que, sem abandonar o secundário, dedicou-se à constituição do saber da escola elementar." (Educação e Pesquisa, v.30, p.480).

Nesse contexto, as primeiras obras didáticas tinham grande relação com o governo e havia enorme preocupação com o ensino da moral. Aos poucos, surgiram preocupações não só com o conteúdo, mas também com os métodos pedagógicos. 
Com o advento da Escola Nova, muitas mudanças sobre o modo de ensinar passaram a se cristalizar por meio dos livros didáticos, pois o que estava em jogo não era somente a transmissão de conhecimentos; mais do que ensinar, a preocupação passou a ser como educar.

Dos primeiros manuais, que traziam "lições" de como ensinar, desenvolveu-se no mercado editorial o ramo dos didáticos. Esse material passou a ser um importante instrumento de interação entre o sujeito e o conhecimento, tendo amplo acompanhamento das publicações pelo governo, que passou a estabelecer encaminhamentos de como ensinar e sugestões dos livros mais adequados para adoção nas escolas públicas.

Esse processo ajuda a compreender como o livro didático veio ganhando destaque nos últimos tempos como principal instrumento de desenvolvimento das aulas. Um dos estudos desenvolvidos por João Wanderley Geraldi, aponta como a identidade do professor veio se alterando e transitando por três diferentes caminhos até chegar a um maior contato com o livro didático.

Em um primeiro momento, o professor era aquele quem produzia o conhecimento, caracterizando-se por um estudioso ou pesquisador. Depois, passou a ser visto como aquele que apenas transmitia o conhecimento. Atualmente, sua principal característica é controlar a aprendizagem, alternando momentos em que assume o papel do protagonista e momentos em que torna-se mais um coadjuvante no processo de ensino e de aprendizagem. Cabe a ele selecionar qual o material didático que será usado e qual o tempo que será dedicado para isso. Ou seja, de fazer suas próprias escolhas dentro de um universo pré-determinado.

De acordo com Geraldi, o professor passa a ser atualmente o organizador do tempo didático e por isso, podemos pressupor que o livro didático ocuparia, ao seu lado, o papel de conduzir a aprendizagem por meio de atividades seqüenciadas. Dessa forma, esse material atuaria também como mediador na relação entre o aluno e o objeto de estudo.

Um outro fator também contribuiu para o desenvolvimento dos didáticos: a tecnologia, na medida em que permitiu a produção de materiais cada vez mais sofisticados, com projetos gráficos diferenciados, facilitando as condições de trabalho do professor.

Dessa forma, independentemente da formação do professor, diferentes alunos poderiam ter as mesmas informações para aprender: no livro já haveria a definição dos conteúdos, as respostas para os exercícios, os encaminhamentos para as intervenções e uma síntese das metodologias utilizadas, baseadas em teorias atuais e de relevância nacional ou internacional. Esse fator acabou 
por contribuir para a formação dos professores, pois a partir da democratização do ensino e do aumento da quantidade de escolas e de faculdades de pedagogia, viu-se emergir no mercado uma grande quantidade de professores que se formavam em cursos rápidos ou superficiais, sem muito embasamento teórico.

Nos estudos de Geraldi, é possível identificar algumas críticas a esse processo que, aos poucos, foi delegando maior importância aos livros didáticos: esse autor chama a atenção para o fato de que, para atenuar o despreparo do professor, bastaria oferecer-lhe um livro que, sozinho, ensinasse aos alunos tudo o que fosse preciso e, dessa forma, a educação estaria garantida.

Atualmente, vem-se buscando um equilíbrio entre o papel do professor e o do material didático impresso para que os livros não sejam considerados como única referência para os alunos, atuando como verdadeiros livros de textos e como roteiros para as aulas. Cabe ao professor "pilotar" este material, exercendo sua autoridade neste processo de construção do conhecimento.

Apesar da sua crescente penetração nas escolas e no mercado editorial, o livro didático nunca foi valorizado pelos estudiosos e bibliógrafos, pois era visto como uma produção de menor valor. Ainda hoje há muita discussão acerca da sua influência na formação dos alunos, uma vez que esse material não se apresenta isento, ou seja, vem carregado de ideologias e de interesses financeiros. Porém, não se pode negar sua contribuição para o trabalho do professor em épocas ou locais em que não se encontravam (ou que ainda não se encontram) facilmente instituições de formação de professores. De acordo com Alain CHOPPIN, pesquisador francês na área de história e educação, é possível identificar variadas funções para o livro didático. Segundo ele:

É de se destacar ainda que os livros escolares assumem, conjuntamente ou não, múltiplas funções: o estudo histórico mostra que os livros didáticos exercem quatro funções essenciais, que podem variar consideravelmente segundo o ambiente sociocultural, a época, as disciplinas, os níveis de ensino, os métodos e as formas de utilização. (Educação e Pesquisa, v.30, p.552-3).

Dentre essas funções é possível destacar uma função referencial, em que o livro didático é a tradução do programa de ensino, ou seja, contém conteúdos que um grupo acredita serem importantes para os alunos saberem; uma função instrumental, em que o livro coloca em prática métodos de aprendizagem (memorização de conteúdos, aquisição de competências, resolução de 
problemas etc.); uma função ideológica e cultural, que é a função mais antiga, valorizando a língua e a cultura das classes dirigentes, doutrinando politicamente os alunos e uma função documental, cujo objetivo do livro é reunir textos e imagens para favorecer o olhar crítico dos alunos ao comparar diferentes documentos.

Na reforma educacional do Canadá, promovida pelo Ministério da Educação desse país, conforme documento publicado em 1997, é possível observar, dentre outros fatores, como o livro didático ocupa um espaço importante na educação dos alunos. De acordo com este documento, os livros didáticos determinam os principais caminhos para o desenvolvimento dos alunos no que se refere à aprendizagem dos diversos conteúdos, inclusive na construção de valores. Por esta razão, cada cidade pode construir seu próprio sistema de ensino, de acordo com seus próprios critérios sociais. Vale ressaltar que esses materiais são avaliados e revistos com freqüência, podendo também sofrer alterações por parte dos professores de acordo com a realidade local. Cabe ao Ministério da Educação do Canadá fazer este acompanhamento, avaliando os materiais existentes, recomendando ou não seu uso na sala de aula.

No Brasil, fenômeno semelhante vem ocorrendo no que se refere à adoção de livros didáticos na rede pública. Desde 1983, o governo federal vem investindo na compra de livros didáticos para serem trabalhados na escola pública, como forma de melhorar a qualidade de ensino no país. Para isso, mantém um programa de aquisição e distribuição gratuita de livros para o Ensino Fundamental e Médio. A partir de 1997, esse programa começou a ganhar os contornos que tem hoje, com a instituição de um processo avaliativo realizado por equipes de especialistas.

A avaliação dos livros se baseia, principalmente, em um documento elaborado pelo Ministério da Educação e do Desporto, durante o governo de Fernando Henrique Cardoso (19942002), com diretrizes sobre o que e como ensinar: os Parâmetros Curriculares Nacionais (PCNs). O objetivo desses documentos é definir metas de qualidade que instrumentalizem o professor no planejamento das aulas, na reflexão sobre a prática educativa e na análise do material didático.

Nos PCNs são definidos os objetivos, os conteúdos, a forma de avaliar e as orientações didáticas de cada área do conhecimento, conforme texto do próprio documento:

Os Parâmetros Curriculares Nacionais apontam questões de tratamento didático por área e por ciclo, procurando garantir coerência entre os pressupostos teóricos, os objetivos e os conteúdos, mediante sua 
operacionalização em orientações didáticas e critérios de avaliação. Em outras palavras, apontam o que e como se pode trabalhar, desde as séries iniciais, para que se alcancem os objetivos pretendidos. (1997, p.93)

Esses procedimentos visam contribuir para uma melhor qualidade na educação; porém, isso não deve ser interpretado como uma padronização. Cabe à equipe de educadores da escola propor seu próprio projeto político pedagógico, flexibilizando os currículos, de acordo com as suas necessidades.

Por fim, vale ressaltar que o livro didático não deve ser considerado como o único instrumento que contribui para a educação dos alunos. Outros materiais impressos, como quadros, mapas, livros de literatura, enciclopédias, revistas, jornais etc ou materiais áudio-visuais como filmes, CD-Rom, internet, entre outros, acabam por complementar o trabalho desenvolvido nos livros didáticos e devem ser utilizados pelos professores em suas aulas.

Mas, acima de tudo, a intervenção constante e atenta do professor sempre comprometerá positivamente a dinâmica das aulas, a fim de promover uma construção do conhecimento com cada vez mais qualidade. 


\section{O estudo de língua portuguesa}

Desde o início dos anos oitenta, algumas pesquisas no campo da construção do conhecimento possibilitaram avanços principalmente no que se refere à aquisição da escrita. Este novo quadro permitiu reflexões sobre a finalidade e os conteúdos do ensino de língua materna, em que é possível destacar a consideração do que os alunos já sabem a respeito dos objetos de estudo; o cuidado com a não escolarização das atividades de leitura e de produção de texto e a redução da importância dada ao ensino descontextualizado da gramática. É neste período que se desencadeia um esforço de revisão das práticas de ensino da língua, na direção de orientá-las para a ressignificação da noção de erro, para a admissão das variedades lingüísticas próprias dos alunos, muitas delas marcadas pelo estigma social, e para a valorização das hipóteses lingüísticas elaboradas pelos alunos no processo de reflexão sobre a linguagem e para o trabalho com textos reais, ao invés de textos especialmente construídos para o aprendizado da escrita.

Enfim, pode-se dizer que se consolidaram práticas de ensino em que tanto o ponto de partida, quanto o ponto de chegada é o uso da linguagem, pois a razão de ser das propostas de leitura e escrita é a compreensão ativa e não a decodificação e o silêncio, incentivando a interlocução e o pensar sobre a linguagem para poder compreendê-la e utilizá-la apropriadamente às situações e aos propósitos definidos. Os sujeitos se apropriam dos conteúdos, transformando-os em conhecimento próprio, através da ação sobre eles, mediada pela interação com o outro. Não é

diferente no processo de aquisição e desenvolvimento da linguagem. É nas práticas sociais, em situações lingüisticamente significativas, que se dá a expansão da capacidade de uso da linguagem e a construção ativa de novas capacidades que possibilitam o domínio cada vez maior de diferentes padrões de fala e de escrita.

No processo de ensino-aprendizagem nos diferentes anos iniciais do Ensino Fundamental, por exemplo, espera-se que o aluno amplie o domínio ativo do discurso nas diversas situações comunicativas, de modo a possibilitar sua inserção no mundo da escrita, ampliando suas possibilidades de participação social no exercício da cidadania.

É preciso ensinar os alunos a utilizar a linguagem na escuta e produção de textos orais e na leitura e produção de textos escritos de modo a atender a múltiplas demandas sociais, responder a 
diferentes propósitos comunicativos e expressivos, e considerar as diferentes condições de produção do discurso.

Ao refletir sobre como proceder para ter acesso, compreender e fazer uso de informações contidas nos textos, será possível reconstruir o modo pelo qual se organizam em sistemas coerentes; operar sobre o seu conteúdo identificando aspectos relevantes, organizando notas, elaborando roteiros, resumos, índices, esquemas etc.; contrapor diferentes opiniões; inferir sobre as possíveis intenções do autor marcadas no texto e utilizar os conhecimentos adquiridos para expandir sua capacidade de uso da linguagem, ampliando a capacidade de análise crítica.

A base do trabalho deve ser desenvolvida por meio da análise do funcionamento dos gêneros textuais discursivos, tanto orais quanto escritos. Parte-se do pressuposto de que todo texto se organiza dentro de determinado gênero em função das intenções comunicativas. Os gêneros são, portanto, determinados historicamente, constituindo formas relativamente estáveis de enunciados, disponíveis na cultura. Em um gênero é sempre possível identificar seu conteúdo temático (o que é ou pode tornar-se dizível através do gênero); uma construção composicional (estrutura particular dos textos pertencentes ao gênero) e um estilo (configurações específicas utilizadas pelo autor, como uso de figuras de linguagens, pontuação, escolhas vocabulares etc). A noção de gênero refere-se, assim, a famílias de textos que compartilham características comuns, embora heterogêneas, existindo em número quase ilimitado. As sequiências de atividades devem ser organizadas para permitir que a criança entre em contato com vários textos de um determinado gênero, de modo a permitir que possa conhecer mais a respeito de seu funcionamento. 


\section{A prática de leitura e de produção de textos}

Aprender a ler de forma competente é muito mais do que decifrar mensagens, trata-se de procurar um sentido e questionar algo escrito a partir de uma realidade. Para isso, são colocadas em prática estratégias de leitura que auxiliam os alunos a interpretar e compreender os textos lidos de forma mais autônoma. O professor deve estar consciente desses processos para auxiliar seus alunos a construírem seu saber-ler e saber-escrever, formando competentes alunos leitores e escritores de texto.

Para construir essas competências é preciso perseguir os aspectos que dão sentido à presença dos alunos na escola e ao seu aprendizado. É na medida em que se vive num meio sobre o qual é possível agir, discutir, decidir, realizar, avaliar junto com os outros que são criadas as condições mais favoráveis ao aprendizado.

Em uma abordagem mais tradicional, há casos em que a pedagogia, na maior parte do tempo, está baseada no ensino, ou seja, a atividade essencial é realizada pelo professor, é ele quem elabora e constrói. Cabe aos alunos entenderem, responderem ou executarem as tarefas. É preciso partir para uma pedagogia baseada no aprendizado, em que os alunos ensinam a si mesmos, construindo seu saber e suas competências com a ajuda de outros.

Dessa forma, não se ensina uma criança a ler, é ela quem se ensina a ler com a ajuda de seus professores, colegas, instrumentos da aula, pais e de todos os leitores encontrados. Cada um possui seus próprios processos, suas etapas, seus obstáculos a vencer e a ajuda vem do confronto com as proposições das outras pessoas com quem está trabalhando. Nessa perspectiva, cabe ao professor fazer com que a vida em sala de aula proporcione às crianças situações de leitura simultaneamente efetivas e muito diversificadas; ajudar os alunos a interrogarem o escrito, procurarem um sentido, levantarem hipóteses a partir de indícios, verificarem-nas e ajudar os alunos a elucidarem suas próprias estratégias de leitura.

Para desenvolver essas atividades é preciso partir do pressuposto de que ler é atribuir diretamente um sentido a algo escrito. Diretamente, ou melhor, sem passar pelo intermédio da 
decifração (letra por letra, sílaba por sílaba, palavra por palavra) nem da oralização (grupo respiratório por grupo respiratório); questionar algo escrito como tal a partir de uma expectativa real (necessidade-prazer) em uma verdadeira situação de vida. Questionar um texto é fazer hipóteses de sentido a partir de indícios levantados e verificar essas hipóteses. Tal questionamento se desenvolve através de toda uma estratégia de leitura que nada tem a ver com uma decifração linear e regular (que parte da primeira palavra da primeira linha para chegar à última palavra da última linha). Essas estratégias podem variar de um leitor para outro, de um texto para outro e, para um mesmo leitor e um mesmo texto, de um objetivo para outro; por fim, ler é ler escritos reais, que vão desde um nome de rua numa placa até um livro, passando por um cartaz, uma embalagem, um jornal, um panfleto, ou outros, num momento em que se precisa realmente deles numa determinada situação de vida. É lendo de verdade, desde o início, que alguém se torna leitor e não aprendendo primeiro a ler.

Em um trabalho com leitura é preciso levar-se em conta alguns pressupostos básicos para se desenvolver esse ato de forma competente. Para isso, nenhuma tarefa de leitura deve ser iniciada sem que se encontrem motivos para ela, ou seja, sem que esteja claro o seu sentido. $\mathrm{O}$ aluno tem de saber o que deve fazer, isto é, conhecer os objetivos que se pretende alcançar com sua atuação. Os objetivos dos leitores em relação aos textos podem ser variados e estão relacionados com a diversidade de textos a que tiverem acesso. A escolha das leituras feita pelos alunos parte, em um primeiro momento, de uma resposta a uma necessidade pessoal. De acordo com o seu objetivo é que serão procurados os textos. Os objetivos da leitura em situações de ensino são:

- Ler para obter uma informação precisa - Localizar algum dado que nos interessa, por exemplo: consulta a um dicionário.

- Ler para seguir instruções - A leitura é um meio que deve nos permitir fazer algo concreto, por exemplo: regras para um jogo.

- Ler para obter uma informação de caráter geral — Não precisamos saber detalhadamente de que trata o texto, mas somente ter uma idéia geral, por exemplo: ler somente as manchetes, lides ou chamadas em um jornal. 
- Ler para aprender - Ampliar os conhecimento por meio da leitura, por exemplo: pesquisar ou estudar elaborando resumos.

- Ler para revisar um escrito próprio - É uma leitura crítica que verifica a adequação do texto, por exemplo: auto-revisão das redações escritas.

- Ler para comunicar um texto a um auditório - O leitor utiliza uma série de recursos, como entonação, pausas, ênfase em determinados aspectos, para que o público possa compreender a mensagem emitida, por exemplo: ler poesia em uma apresentação.

- Ler para praticar a leitura em voz alta - Pretende incentivar os alunos a lerem com clareza, rapidez e fluência, porém não tem sentido o único objetivo da leitura ser apenas dizer em voz alta o que está escrito, é preciso compreender o que se lê. Para isso, uma leitura anterior, individualizada e silenciosa, parece ser uma boa preparação para o entendimento do texto. Como exemplo, apresentaremos novamente a leitura de poemas.

- Ler para verificar o que se compreendeu - Verificar a compreensão do texto, respondendo a perguntas de entendimento. O texto escrito pelo autor só se completa quando é lido por um leitor: autor - texto - leitor . Essa leitura envolve uma compreensão do que se lê.

Ler deixa de ser um ato de decodificar e passa a ser um ato cognitivo. O leitor passa a ter um papel ativo, pois atribui sentido ao texto. O texto deixa de ser um depositário de mensagens e passa a ser um objeto de interlocução entre leitor e autor. Mas, não basta ler, é preciso analisar os textos para tornar-se um escritor competente, por meio de atividades de interpretação de texto.

Dessa forma, as competências relacionadas às atividades de leitura fazem parte de um amplo e complexo conjunto. É possível destacar, a seguir, alguns exemplos de situações que envolvam a construção dessas competências. Para cada competência principal, são elencadas outras, tidas como competências relacionadas.

1. Localizar indícios que ajudem na tarefa de compreensão de um texto:

- Saber abordar um texto de imediato com uma procura do sentido e uma leitura silenciosa; 
- Saber encontrar indícios para emitir hipóteses, indícios estes ligados à situação de vida, que não necessariamente as palavras (natureza e formato do suporte, valor da tipografia etc.);

- $\quad$ Saber distinguir se o texto é manuscrito, impresso ou mimeografado;

- Saber explorar a relação texto-imagem, a disposição de um texto na página, a presença ou ausência de números (encontrar uma data, um preço de um ingresso, uma hora), a pontuação;

- Saber utilizar instrumentos metodológicos para explorar um texto: sumário, índice, ordem alfabética, organização em rubricas, hierarquia do tipo de letra etc.

- Coletar esses indícios como informações que serão processadas para construir o sentido do texto.

2. Saber verificar suas hipóteses durante um ato de leitura:

- $\quad$ Pelo sentido;

- $\quad$ Pelo contexto;

- $\quad$ Pela totalidade do texto;

- $\quad$ Pelo reconhecimento numa palavra das letras que permitem fazer diferenciações;

- $\quad$ Por meio de uma ação real, tal como: um jogo cujas regras devem ser descobertas, utilizar um manual de operação, executar uma receita, brincar com mensagens escritas, recortar uma história em quadrinhos e reconstruí-la, classificar documentos, escrever um texto para os respectivos desenhos - com referência ao tema principal da aula e, em última instância, recorrendo ao professor, aproveitando instrumentos de referência construídos pela aula (fichários, painéis, repertórios etc.).

Para desenvolver essas competências, um trabalho de leitura e compreensão de textos envolve um contato com uma grande diversidade de textos e o ensino de estratégias de compreensão leitora. Dessa maneira estaremos formando leitores mais autônomos e competentes, capazes de aprender a partir de textos, não importando seu gênero, estrutura ou grau de dificuldade. Quem lê deve ser capaz de interrogar-se sobre sua própria compreensão, estabelecer relações entre o que lê e o que faz parte do seu acervo pessoal, questionar seu conhecimento e modificá-lo, estabelecer generalizações que permitam transferir o que foi aprendido para outros textos diferentes etc. 
Para que a leitura se processe de modo eficaz, duas condições são essenciais: a qualidade dos conhecimentos temáticos disponíveis pelo leitor e a integridade das vias fonológica e lexical, para que as palavras sejam reconhecidas com rapidez.

Os conhecimentos temáticos se referem aos conhecimentos que o leitor possui a respeito do tema lido. Essa quantidade de conhecimentos vai influenciar a compreensão de informações explícitas e implícitas contidas no texto. Por isso é importante fazer um levantamento sobre o que aluno conhece do tema e, caso não tenha muitos conhecimentos, aproximá-lo ao máximo do conteúdo ajudando-o a estabelecer relações com algum fato que conheça. Quanto mais o leitor conhecer, mais possibilidades de fazer inferências terá.

As vias fonológica e lexical são usadas para identificar-se uma palavra. $\mathrm{O}$ uso da via lexical utiliza-se do processo de reconhecimento visual do material gráfico e da procura, na memória, dos vocábulos conhecidos. Como produto do uso desta via o reconhecimento se dá pelo sentido global das palavras. Esta via é utilizada, por exemplo, por alunos de Educação Infantil ainda não alfabéticos, quando estabilizam algumas palavras, como os nomes próprios. Apesar de não conhecerem o nome de muitas letras nem reconhecerem seu valor sonoro, conseguem ler pela via lexical. Porém, muitos alunos alfabéticos, que apresentam dificuldades na decodificação das palavras, tentam compensá-las desenvolvendo estratégias que envolvam a via lexical, ou seja, o reconhecimento global da palavra. Por isso, acabam tentando adivinhá-las por meio das características visuais das palavras.

$\mathrm{Na}$ via fonológica, o processo usado é a identificação de letras, a análise de segmentos silábicos e fonêmicos e a reconstrução de cadeias de som. Esse processo vai gerar como produto a correspondência letra/som. Consiste em traduzir os símbolos gráficos em fonemas. Quanto mais automatizado estiver este processo, maior será a rapidez da leitura. Se o leitor lê sem esforço, estará liberado para compreender o texto mais facilmente. Uma leitura fluente envolve as seguintes estratégias:

- $\quad$ Estratégias de seleção: ler apenas os índices úteis — Por exemplo: não precisamos ler atentamente a letra que vem após o Q, pois será sempre o U; 
- $\quad$ Estratégias de antecipação: prever o que está por vir com base em informações ou inferências - Por exemplo: gênero, autor, título, características dos suportes e da superestrutura nos informam o que encontraremos em um texto;

- $\quad$ Estratégias de inferências: compreender o que não está dito no texto de forma explícita - Por exemplo: são adivinhações baseadas em pistas dadas pelo próprio texto. Por tratarem-se de suposições, às vezes não se confirmam, porém o próprio contexto deve dar as dicas sobre a interpretação, uma vez que as inferências e deduções não podem ser aleatórias;

- Estratégias de verificação: torna possível verificar a eficácia das outras estratégias, confirmando ou não as suposições — Por exemplo: questões de entendimento sobre o texto.

Esses procedimentos devem ser planejados mediante atividades para serem propostas antes, durante e depois da leitura.

Antes da leitura:

- Compreender os propósitos da leitura, ou seja, seu objetivo - Por exemplo: O que tenho que ler? Por que tenho que ler? Os objetivos da leitura determinam a forma em que um leitor se situa frente ela e controla a compreensão do texto.

- Ativar os conhecimentos prévios sobre o conteúdo em questão - Por exemplo: O que sei sobre o autor, o gênero ou o conteúdo do texto? As atividades que têm como objetivo principal levantar os conhecimentos prévios dos alunos são consideradas como etapas fundamentais. De acordo com a Psicologia Genética, disciplina que estuda o processo de construção do conhecimento, todo conhecimento é originário de conhecimentos anteriores. Os conhecimentos anteriores funcionam como marco assimilador, a partir do qual dão significados aos novos objetos de conhecimento. Os textos escolhidos para estudo geralmente trazem novos conhecimentos ou informações aos leitores, porém, é importante que estes já estejam ativando seus conhecimentos anteriores. À medida que os novos conhecimentos vão sendo assimilados, as noções já construídas vão se modificando, se enriquecendo. Passa-se de um estágio de menor conhecimento para um de maior conhecimento.

- $\quad$ Estabelecer previsões sobre o texto - Deduzir informações sobre o tipo de texto, informar-se sobre o que será lido, priorizar os itens que deverão ser lidos com mais atenção, dependendo do objetivo da leitura. 
Durante a leitura:

O leitor passa a ter um papel ativo, fazendo previsões durante o texto, formulando perguntas e recapitulando informações. Nesse processo o professor deve ser um modelo de leitor significativo, ou seja, ativo . Nesses casos, ensina-se estratégias quando:

- $\quad$ Dirige-se a atenção ao fundamental — Por exemplo: Qual a informação essencial para eu conseguir o meu objetivo de leitura?

- Avalia-se a consistência do texto e sua compatibilidade com o conhecimento prévio — Por exemplo: As idéias expressadas no texto têm coerência com o que penso?

- $\quad$ Pratica-se a revisão e recapitulação periódica do que está lendo - Por exemplo: Qual a idéia fundamental deste parágrafo?

- Elaboram-se e provam-se inferências - Por exemplo: Como será resolvido o problema desta narrativa?

Depois da leitura:

Após a leitura, para se verificar o que se compreendeu sobre o texto é preciso que o aluno seja capaz de: fazer resumos e responder perguntas sobre o que foi lido.

Dessa forma, espera-se formar um leitor competente, alguém que compreende o que lê, que possa aprender a ler também o que não está escrito, identificando também elementos implícitos, que estabeleça relações entre o texto que lê e outros textos já lidos, que saiba que vários sentidos podem ser atribuídos a um texto, que consiga justificar e validar a sua leitura a partir da localização de elementos discursivos.

As questões de interpretação, por sua vez, seguem basicamente três abordagens:

1. A análise do texto em uma abordagem conteudista - Exige a consulta ao texto e as perguntas/respostas são mais fechadas. A operação principal do pensamento a ser desenvolvida é a memória e a atividade mais recorrente é a consulta. 
2. A análise do texto em uma abordagem estruturalista - Exige um olhar mais analítico sobre o texto, baseado na sua estrutura. A principal operação do pensamento é o raciocínio e a atividade mais recorrente é a análise da estrutura do texto ou encadeamento dos parágrafos.

3. A análise do texto em uma abordagem baseada na análise do discurso - Assume um caráter mais polêmico, devido à sua subjetividade em alguns casos, permitindo mais de uma interpretação às questões propostas. A operação do pensamento a ser desenvolvida é a capacidade de construir relações e realizar críticas. A atividade consiste em estabelecer uma interação entre autor e leitor, desvelando os recursos utilizados ou mensagens implícitas existentes no texto. Constrói-se um espaço de interlocução entre autor e leitor.

Para isso, em uma análise textual, geralmente são apresentados os seguintes tipos de questões:

- Domínio do vocabulário: as respostas podem ser obtidas mediante dedução, análise da formação das palavras ou deduzidas pelo seu contexto. A confirmação pode ser obtida pelo próprio dicionário.

- Compreensão do texto: questões que envolvam a volta ao texto, exigindo principalmente a habilidade de localização das respostas.

- Interpretação do texto: perguntas mais abertas que exigem a capacidade de realizarse inferências e deduções a partir das informações fornecidas pelo texto. Trata-se de desvelar o que está escrito nas entrelinhas, o que não foi dito, o que está implícito nas pistas fornecidas pelo texto.

- Extrapolação do texto: permite a extrapolação das respostas, a partir das informações do texto. Desenvolve a capacidade crítica e argumentativa, estabelecendo relações entre o texto e os conhecimentos prévios dos alunos sobre o conteúdo em questão. Permite também a generalização de alguns dos recursos utilizados pelos autores, aplicando-os em diferentes contextos.

Para desenvolver estas questões, a seleção de materiais para leitura dos alunos implica em critérios, nos quais entram em jogo as diferentes concepções de aprendizagem de compreensão leitora, das funções do texto, das representações do desenvolvimento sócio-afetivo dos alunos etc. Além disso, os textos devem abranger uma diversidade de gêneros, de acordo com a proposta dos 
Parâmetros Curriculares Nacionais. Um trabalho que prevê um contato com uma diversidade de textos, permite que o aluno conheça diferentes estruturas textuais, amplie seu vocabulário e enriqueça sua produção textual, obtendo melhor desempenho na sua competência comunicativa. Os textos, como unidades comunicativas, manifestam diferentes intenções do emissor. Procuram informar, convencer, seduzir, entreter etc. $\mathrm{O}$ fato do aluno ter contato com diferentes gêneros textuais possibilita que ele seja capaz de escolher o texto que esteja mais adequado com as suas intenções de comunicação. É importante também que os textos sejam originais e integrais, evitando-se as adaptações. No caso de haver cortes, deve-se indicá-los com colchetes e reticências [...]. A escolha dos autores deve ser criteriosa, representativa da literatura brasileira e abarcar diferentes épocas. É importante que os alunos entrem em contato com diferentes autores nacionais, em sua maioria, e com alguns internacionais.

Por fim, é essencial ressaltar que cabe ao professor ensinar seus alunos a realizarem uma leitura crítica, em que eles sejam capazes de atribuir sentido ao que lêem, distinguir contextos, funções, estilos, intenções, argumentos, pontos de vista etc, para que se tornem leitores mais competentes nas diferentes situações comunicativas, capazes de compreender o mundo ao seu redor e agir de maneira crítica e reflexiva.

Ensinar a ler na escola também implica em estabelecer uma relação afetiva entre leitura e escrita. Por meio da leitura e da análise textual é possível entrar em contato com as características da linguagem escrita que serão necessárias acionar ao escrever. Nas atividades de produção de texto, os alunos irão produzir textos, colocando em prática as descobertas feitas durante todo o processo de leitura e de interpretação. A principal finalidade é contribuir para a formação de escritores competentes, capazes de produzir os mais variados textos, coerentes e coesos.

Para aprender a escrever, é preciso escrever e, principalmente, ter a prática de revisar seu próprio texto com o objetivo de reescrevê-lo para poder melhorá-lo. Nessa nova abordagem, a produção de textos passa a ser fruto de um trabalho sistemático de aprendizagem, que prevê o papel do professor, e, por conseguinte, do livro didático como mediadores desse processo.

De acordo com os PCNs de Língua Portuguesa são previstos os seguintes gêneros discursivos para o trabalho com a linguagem escrita no Ensino Fundamental: receitas, instruções de uso, listas; textos impressos em embalagens, rótulos, calendários; cartas (formais e informais), 
bilhetes, postais, cartões (de aniversário, de Natal etc.), convites, diários (pessoais, da classe, de viagem etc.); quadrinhos, textos de jornais, revistas e suplementos infantis: títulos, lides, notícias, classificados etc.; anúncios, slogans, cartazes, folhetos; parlendas, canções, poemas, quadrinhas, adivinhas, trava-línguas, piadas; contos (de fadas, de assombração etc.), mitos e lendas populares, folhetos de cordel, fábulas; textos teatrais; relatos históricos, textos de enciclopédia, verbetes de dicionário, textos expositivos de diferentes fontes (fascículos, revistas, livros de consulta, didáticos etc.) e de outras áreas, textos normativos, tais como estatutos, declarações de direitos etc.

A tarefa de escrita de textos em geral envolve várias competências, pois, ao escrever, devese considerar:

- $\quad$ a quem o texto se destina;

- $\quad$ o propósito que justifica o ato de produzir o texto;

- $\quad$ a mensagem: o que vai ser dito;

- $\quad$ o gênero: se é uma carta, um poema, uma história, um relatório, uma notícia etc.;

- $\quad$ o portador: se vai ser publicado em um livro, no mural ou ficará no próprio caderno ou pasta;

- todos os aspectos relacionados com a escrita: coerência, linguagem, gramática, pontuação, ortografia;

- $\quad$ a revisão do texto pronto, além de uma leitura crítica para avaliar sua qualidade e eficácia. Aquele que escreve tem de ser, quase ao mesmo tempo, autor, leitor, revisor.

Além de todos esses aspectos, devemos considerar também que escrever envolve um desejo, portanto é preciso estimular este desejo. A criança precisa estar afetivamente ligada com o que vai escrever. Cabe ao professor sensibilizar os alunos na apresentação das propostas para que todos se envolvam.

Para se conseguir todos esses aspectos, desenvolvendo-se as competências de bons escritores, os alunos devem ter bons modelos de referência, do contrário, torna-se quase impossível construir essa habilidade. Escrever bem é resultado tanto da leitura de muitos e diferentes textos como também da possibilidade de pensar e conversar sobre o ato de redigir, ou seja, é preciso receber ajuda para pensar na organização do texto, analisar suas características e olhar a própria produção com olhos críticos. Para melhorar a capacidade de redigir dos alunos é decisiva a contribuição do professor, selecionando boas propostas de produção que atendam os requisitos acima e intervindo enquanto os textos estão sendo escritos ou quando terminados. Hoje, discute-se 
que mais do que treinar técnicas de redação, é preciso criar situações de produção de textos. Sabese que a capacidade de produzir textos próprios depende em grande medida da possibilidade de operar com textos produzidos por outras pessoas, ou seja, a criação não é simplesmente um talento, mas um árduo trabalho, a partir de textos já escritos.

Assim, é importante que as atividades de escrita privilegiem a paráfrase, ou seja, aprendese a escrever a partir das idéias do outro, assimilando-as e reformulando-as para que se possa, aos poucos, alcançar um verdadeiro processo de autoria. Retomando a idéias de Vygotsky, é possível que os alunos avancem em seus conhecimentos se a escola estiver trabalhando na sua Zona de Desenvolvimento Proximal, ou seja, atuando junto àquilo que o aluno consegue avançar, porém com ajuda. A paráfrase/reprodução seria uma ponte entre o que ele já sabe e o que ele não tem condições de apreender sozinho naquele momento.

Porém, é importante ressaltar que as atividades de escrita devem conter propostas de naturezas distintas. De acordo com Maria José Nóbrega, em sua dissertação de mestrado intitulada Paráfrase, autoria e processos de assimilação da palavra do outro, há quatro categorias para abordá-las: a transcrição, a reprodução, o decalque e a autoria, nas quais me baseei para análise das propostas compiladas.

As atividades de transcrição consistem em fazer com que os alunos reproduzam textos que saibam de memória. Esse tipo de atividade pode ser realizada com parlendas e trava-línguas, pois o que está em jogo não é o que irá ser escrito, mas sim como será escrito. Ao se definir o conteúdo, o aluno pode apoiar-se na estrutura que está fixa e passar a preocupar-se com outros aspectos do texto, como, por exemplo, a grafia das palavra, a pontuação etc.

As atividades de reprodução permitem que os alunos reescrevam textos que já conheçam, usando suas palavras. Os contos tradicionais são ótimos exemplos em que é possível trabalhar-se com a reprodução. Nessa atividade, o aluno já sabe quais serão os conteúdos presentes no texto que irá escrever e poderá ocupar-se com a forma como irá colocá-los no papel, ressignificando o texto à sua maneira.

Uma outra categoria, que envolve a autoria, permite que o aluno defina o que e como irá escrever. Porém, mesmo com toda essa liberdade de criação, é esperado que se apóie em modelos analisados anteriormente, reinterpretando-os ao seu modo.

Por fim, as atividades de decalque, propõem a reescrita de textos lacunados nos quais os 
alunos já teriam a forma do texto definida, alterando alguns trechos. Os poemas ou textos com repetições são os gêneros ideais para este tipo de trabalho, pois os alunos podem se apoiar em um certo modelo e criar alguns trechos para compor o texto.

No que se refere especificamente à escrita de poemas, o uso da palavra deve ser visto sempre como uso criativo, em que a palavra aparece de uma maneira pessoal. Por mais que se inicie na forma da repetição, ao se declamar poemas que se sabe de cor, aos poucos o autor vai "brincando com as palavras", lendo e repetindo versos, apoiando-se neles até conseguir recriá-los. Apesar de a poesia começar na repetição, acaba tornando-se a criação em máximo grau, porque na poesia cada palavra tem seu papel, não apenas por seu significado, mas por seu ritmo, pela sua sonoridade, pela forma como se relaciona com as outras palavras e até mesmo pelo seu aspecto visual. Na poesia, a escolha por uma determinada palavra acaba por transmitir sensações e emoções diferentes, sendo uma manifestação criativa e expressiva do homem. Porém, apesar de um poema poder ter temas variados, os mais comuns são sempre amor, valorização da natureza, épico, algum feito heróico etc. A palavra é original, mas um poeta recorre a temas clássicos da literatura mundial, apropriando-se de idéias contidas em outros poemas. A palavra "poesia" tem sua origem no grego: "poíesis", que significa ação de fazer, criar alguma coisa. Porém para muitos teóricos, dentre eles Aristóteles, a poesia está intimamente ligada à idéia de imitação, pois estaria presente desde a infância, transmitindo os primeiros conhecimentos. Segundo Aristóteles, a imitação seria um meio pelo qual o homem experimenta o prazer e, por meio dessa contemplação, imita as coisas: como elas são ou como os outros dizem que são. A poesia começa na repetição, tornando-se um exercício inicial de criação. Ao escrever um poema os alunos irão apoiar-se na palavra do outro para alterar uma palavra por outra, empregar um mesmo recurso lingüístico já empregado por algum outro escritor etc. Ou seja, o que se obtém são sempre variações sobre uma mesma forma.

Por isso, analisar como se manifestam essas categorias nas atividades de escrita, ajudará os alunos a conseguirem escrever melhor. Para tanto, serão apresentadas a seguir algumas propostas presentes em livros didáticos, que contemplem essas características. 


\section{ANÁLISE DE DADOS}

Uma vez que os livros didáticos fazem, cada vez mais, parte do cotidiano das salas de aula, optou-se por selecionar boas propostas de escrita presentes nesses materiais.

Partiu-se da concepção de que para ajudar os alunos a avançarem em seus conhecimentos é preciso propor o contato com bons modelos para que escrevam seus próprios textos a partir deles. Dentre as obras selecionadas para esta pesquisa, alguns critérios foram estabelecidos, como, por exemplo, serem obras aprovadas pelo Programa Nacional do Livro Didático, realizado pelo governo federal. Para fins de organização, serão apresentadas pequenas resenhas de cada uma das coleções, feitas principalmente a partir do documento oficial, redigido pelo governo.

As propostas estão agrupadas por ano/série, com as respectivas identificações, seguidas de uma breve descrição das atividades de leitura e de escrita e um pequeno comentário sobre elas. Logo na seqüência há a reprodução das principais páginas analisadas. 


\section{Aspectos considerados na seleção das propostas de produção de texto}

Durante essa pesquisa, pretende-se verificar exemplos de atividades de escrita presentes em livros didáticos que tenham como objetivo ajudar o aluno a produzir textos. Partiu-se do pressuposto que, para ajudar os alunos a avançarem nesse processo, é preciso que tenham contato com bons modelos e escrevam seus textos a partir deles. Aos poucos, espera-se que deixem de apenas reproduzir ou copiar textos de outros, libertando-se de modelos e passando a reconstruir significados para alcançar a verdadeira autoria.

Neste sentido, boas propostas de escrita podem auxiliar os alunos a avançarem em seus conhecimentos, tornando-os escritores mais autônomos e competentes.

Dessa forma, o objetivo principal do trabalho consiste em compilar boas propostas de produção de texto para que, ao analisá-las, seja possível verificar como o livro didático se insere nessa proposta, auxiliando os alunos a avançarem nesse processo.

A escolha dos livros a serem analisados se deu a partir de um recorte, dentre as muitas obras presentes no mercado. Foram analisados livros de circulação nacional, publicados por diferentes editoras, atuais (editados a partir de 2000) e aprovados pelo Programa Nacional do Livro Didático de 2004 e/ou de 2007. Não foi possível analisar os livros que participaram da última inscrição proposta pelo governo, pois, caso sejam aprovados pelo MEC, só estarão disponíveis na sala de aula em 2010, estando, até a finalização desta pesquisa, em processo de análise.

Procurou-se também analisar livros com propostas pedagógicas diferenciadas e de autores conhecidos ou não pelos professores. Dessa forma, espera-se construir uma amostra heterogênea e representativa dos diferentes livros que circulam atualmente nas escolas e que fazem parte do programa de análise de livros didáticos realizado pelo governo. Esta análise compõem várias etapas que culminam com a publicação de um guia com o parecer de especialistas e sua respectiva avaliação, conforme assinala o texto abaixo:

Ao final de cada processo, é elaborado o Guia de livros didáticos. Nele são apresentados os princípios, os critérios, as resenhas das obras aprovadas e as fichas de avaliação que nortearam a avaliação dos livros. O Guia é enviado 
às escolas como instrumento de apoio aos professores no momento da escolha dos livros didáticos. ${ }^{1}$

O guia apresenta livros com diferentes concepções e organizações internas. Um dos critérios para a escolha dos livros que foram utilizados nesta pesquisa, foi o fato de serem coleções que contemplam diversos grupos dentre os que foram criados para organizar a avaliação presente no Guia nacional do livro didático. Neste documento, há coleções organizadas por unidades temáticas, coleções organizadas por unidades temáticas sensíveis a gênero/tipo de texto, coleções que apresentam projetos temáticos, coleções organizadas com base em textos e coleções modulares, organizadas por eixos de ensino.

Um outro critério utilizado para seleção dos livros analisados no presente estudo foi o fato dos livros fazerem parte de uma coleção que contemple os anos iniciais do Ensino Fundamental. Todos ainda utilizam a nomenclatura série, comum antes da publicação da lei do Ensino Fundamental de 9 anos. Esta lei, publicada pelo governo em 2006, atesta a importância da ampliação do ensino em mais um ano, principalmente na rede pública, conforme assinala o documento elaborado pelo próprio governo:

O Ministério da Educação vem enviando efetivos esforços na ampliação do ensino fundamental para nove anos de duração, considerando a crescente universalização dessa etapa de ensino de oito anos de duração e, ainda, a necessidade de o Brasil aumentar o número de anos do ensino obrigatório. Essa relevância é constatada, também, ao se analisar a legislação educacional brasileira: a Lei $\mathrm{n}^{\circ} 4.024 / 1961$ estabeleceu quatro anos de escolaridade obrigatória; com o Acordo de Punta Del Este e Santiago, de 1970, estendeuse para seis anos o tempo do ensino obrigatório; a Lei $\mathrm{n}^{\mathrm{o}} 5.692 / 1971$ determinou a extensão da obrigatoriedade para oito anos; já a Lei no 9.394/ 1996 sinalizou para um ensino obrigatório de nove anos de duração, a iniciarse aos seis anos de idade, o que, por sua vez, tornou-se meta da educação nacional pela Lei $\mathrm{n}^{\mathrm{o}}$ 10.172/2001, que aprovou o Plano Nacional de Educação. Finalmente, em 6 de fevereiro de 2006, a Lei n 11.274, institui o ensino fundamental de nove anos de duração com a inclusão das crianças de seis anos de idade. Com a aprovação da Lei ${ }^{\circ} 11.274 / 2006$, mais crianças serão incluídas no sistema educacional brasileiro, especialmente aquelas

\footnotetext{
${ }^{1}$ http://portal.mec.gov.br/seb/index.php?option=content\&task=view\&id=370
} 
pertencentes aos setores populares, uma vez que as crianças de seis anos de idade das classes média e alta já se encontram, majoritariamente, incorporadas ao sistema de ensino - na pré-escola ou na primeira série do ensino fundamental. (MEC, 2006, p.5)

Assim, com a ampliação do Ensino Fundamental, mais crianças, no Brasil todo, poderão freqüentar a escola. Como se trata de uma lei, estados e municípios são obrigados a oferecer a matrícula para todas as crianças de 6 anos. Isso significa um ano a mais de estudo, o que pode fazer muita diferença na vida de crianças que não têm contato freqüente com a língua escrita em casa. Dessa forma, adaptações devem ser feitas para atender às crianças dessa faixa etária, pois não se trata de transferir os conteúdos da antiga $1^{\text {a }}$ série para o $1^{\circ}$ ano.

Dentre os livros analisados, nem todos conseguiram adaptar suas atividades ou produziram um material específico para o $1^{\circ}$ ano até a última adoção para o PNLD, que se deu em 2007. Portanto, esta análise concentrará livros que atendam do $2^{\circ}$ ao $5^{\circ}$ ano, antiga $1^{\mathrm{a}}$ a $4^{\mathrm{a}}$ série do Ensino Fundamental.

Primeiramente será apresentada uma resenha dos livros analisados, com base no documento produzido pelo governo, pela própria fundamentação teórica apresentada pelos autores da obra analisada e pela observação das próprias atividades propostas no livro.

A próxima etapa é a identificação do material, destacando-se sua ficha catalográfica onde é possível identificar o ano ou série, o(s) autor(es), o nome da coleção, a editora e o ano da publicação. Para fins de organização da análise das propostas, os livros serão agrupados por ano/série. Depois, será apresentado o gênero e a sequiência de análise e produção de texto destacada como um bom exemplo de atividade para construir leitores e escritores mais competentes. 


\section{Principais aspectos teóricos e metodológicos dos livros analisados}

Ao apresentar cada uma das seis obras analisadas, optou-se por destacar a sua identificação, com o nome do autor(es), da coleção e da editora, bem como o ano de sua publicação.

Há uma breve análise da coleção, com base na observação das atividades, na leitura das orientações para o professor e no Guia do Livro Didático.

Em princípio, há apresentação da organização dos livros e da sua metodologia. Alguns pontos fortes foram destacados e há algumas considerações levantadas para otimizar o livro em sala de aula.

Por fim, um trecho do documento com a análise realizada pelo governo justifica algumas das considerações apontadas. 


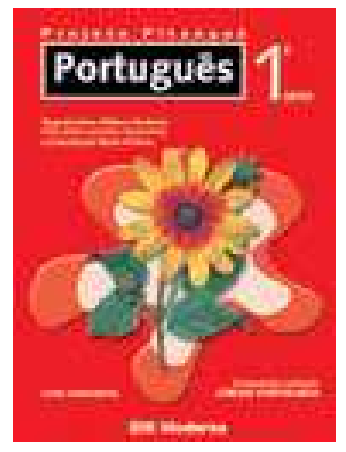

MODERNA (org ), Projeto Pitanguá: português

Obra concebida, desenvolvida e produzida pela

editora Moderna, $1^{\mathrm{a}}, 2^{\mathrm{a}}, 3^{\mathrm{a}}$ e $4^{\mathrm{a}}$ séries. São Paulo:

Moderna, 2005.

Cada um dos quatro volumes são formados por nove unidades que se alongam em torno de um tema. De acordo com o pressuposto teórico-metodológico fundamental da obra presente no manual do professor, destaca-se a busca de desenvolvimento de competências, tanto na teoria construtivista quanto no modelo sociointerativo. O texto torna-se a base para o trabalho, em que leitura e produção textual relacionam-se entre si. A seleção textual é diversa e a leitura é trabalhada na obra como processo de construção de sentidos. Os planos e roteiros de produção escrita são resultados do exercício de leitura. Os destinatários são em geral a classe e os colegas ou a comunidade escolar. De acordo com a avaliação do Guia, esta coleção tem um bom encadeamento das atividades, porém são apresentadas algumas ressalvas em relação à dinâmica de produção de textos e ao estudo da gramática, que deveria priorizar o uso, conforme assinala o próprio documento:

Merecerá esforço também investir nas operações de produção textual (roteiros, gêneros, forma composicional e coerência), e ampliar a interação entre colegas, duplas ou grupos. Muito útil será igualmente estimular o trabalho entre colegas no planejamento, na revisão e na refacção dos textos escritos. O trabalho com o Estudo da língua é complementado, no Manual do Professor, com grande número de instruções, por meio de notas. Será compensador relativizar a carga gramatical e ater-se à observação e à exploração da linguagem em uso.

http://portal.mec.gov.br/seb/arquivos/pdf/Avalmat/pnld2007_port.pdf 


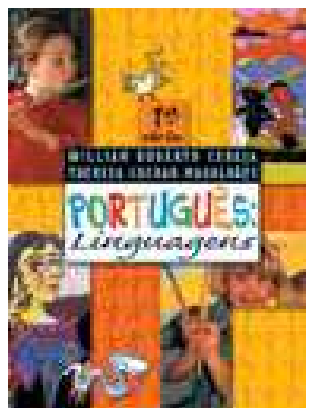

\author{
CEREJA, William Roberto e MAGALHÃES, \\ Thereza Anália Cochar. \\ Português: linguagens, $1^{\mathrm{a}}, 2^{\mathrm{a}}, 3^{\mathrm{a}}$ e $4^{\mathrm{a}}$ séries.
}

São Paulo: Saraiva/Atual, 2006.

A obra é temática e os temas em torno dos quais giram as unidades são variados. Cada livro tem quatro unidades e cada uma delas se abre por imagens, ilustrações e um texto verbal. A obra oferece à criança diversos gêneros e o trabalho com leitura se faz visando à compreensão atenta. Além de localização e reprodução de informações, as atividades investem na compreensão global dos textos e na interpretação de informações e relações implícitas, acionando conhecimentos prévios. A produção de textos escritos é pensada a partir dos gêneros, orientando os alunos a perceberem que todo texto tem um objetivo e um destinatário, embora o espaço de circulação se limite quase sempre à escola. O tema e a forma composicional do gênero a ser produzido são desenvolvidos em correlação com as atividades de leitura e também por meio de discussão coletiva e de instruções específicas. O aluno é incentivado a planejar seu próprio texto e a relê-lo, apoiando-se em quadros que indicam os elementos a serem verificados, porém não é solicitada que seja escrita uma segunda versão, uma vez que não há circulação externa deste material. Este fato merece destaque na avaliação produzida pelo Guia, cujo trecho é transcrito a seguir:

As atividades de produção de textos escritos podem ser enriquecidas com a ampliação do espaço de circulação da escrita dos alunos, de modo a ultrapassar os muros da escola. Nesse sentido, sugere-se diversificar os destinatários dessa produção, prevendo leitores externos à comunidade escolar, assim como orientar a reelaboração dos textos, depois da revisão, para que estejam adequados quando chegarem às mãos dos interlocutores a que se destinam.

http://portal.mec.gov.br/seb/arquivos/pdf/Avalmat/pnld2007_port.pdf 


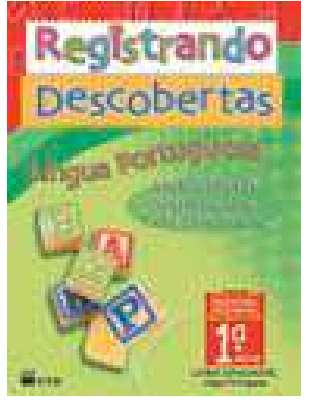

SIMONCELLO, Vera Lucia, ORCHIS, Amália e

CHU, Angelina Verônica de Andrade.

Registrando descobertas: língua portuguesa,

$1^{\mathrm{a}}, 2^{\mathrm{a}}, 3^{\mathrm{a}}$ e $4^{\mathrm{a}}$ séries. São Paulo: FTD, 2005.

$\mathrm{Na}$ concepção teórica do material observa-se a construção dos conhecimentos sobre a linguagem escrita, a partir de uma concepção de língua como um sistema que oferece instrumentos para as práticas orais e escritas.

Cada livro é composto por quatro unidades temáticas e cada uma delas apresenta textos principais complementados e articulados tematicamente com outros. Os temas escolhidos são diversificados no decorrer das unidades e sua abordagem leva o aluno a perceber que existem várias formas de tratá-los. Embora predominem os textos narrativos, há também textos jornalísticos, como notícias, fotografias e legendas, e textos que circulam na esfera familiar e/ou pessoal, como cartas e diários, entre outros.

As atividades exploram diversas estratégias de leitura, entre elas a construção de hipóteses interpretativas, a localização de informações, a compreensão global do texto e a exploração de inferências. O trabalho com a produção de textos escritos é diversificado quanto aos tipos (narrativo, argumentativo, descritivo, instrucional e expositivo) e gêneros textuais (receita, reescrita de conto, história em quadrinhos, carta pessoal e de reclamação, texto publicitário, relato memorialista, autobiografia e regulamento da classe). Porém variam-se os encaminhamentos, conforme assinala este trecho do documento oficial:

As propostas de produção de textos escritos, nos dois primeiros volumes, são, em geral, pouco detalhadas e não explicitam, aos alunos, alguns elementos que compõem as condições de produção (objetivo, leitor, lugar de publicação e esfera de circulação), procedimento que passa a ser recorrente nos dois últimos volumes.

http://portal.mec.gov.br/seb/arquivos/pdf/Avalmat/pnld2007_port.pdf 


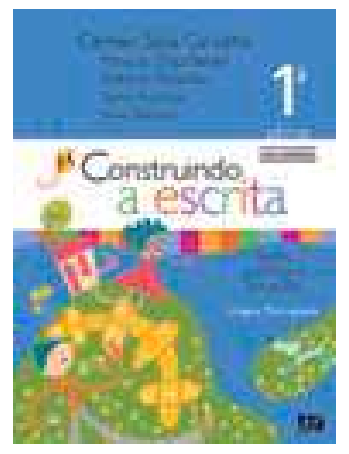

PANACHÃO, Débora, CARVALHO, Carmen

Silvia Cintra Torres, KUTNIKAS, Sarina Bacellar,

SALMASO, Silvia Maria de Almeida e BARALDI,

Maria da Graça Barreto. Construindo a escrita,

$1^{\mathrm{a}}, 2^{\mathrm{a}}, 3^{\mathrm{a}}$ e $4^{\mathrm{a}}$ séries. São Paulo: Ática, 2003.

Os volumes desta coleção são estruturados em duas grandes partes que são independentes. A primeira parte traz sempre um texto com questões voltadas para a compreensão e para a estrutura do gênero que está sendo focalizado, com a presença de gêneros variados. As propostas em torno do estudo dos textos são sempre seguidas pela produção textual, que tem por base o gênero estudado na leitura. Na segunda parte, são introduzidos conteúdos de Gramática e de Ortografia, que partem da observação do uso da língua. A coleção apresenta insuficiências quanto a propostas para uma exploração aprofundada da leitura e para o desenvolvimento da habilidade oral, bem como carece de uma articulação maior entre o trabalho com leitura e produção escrita e o trabalho com análise lingüística.

As propostas de produção textual são relativamente poucas, mas diversificadas e relevantes para o desenvolvimento das habilidades da escrita. A principal qualidade da coleção está na articulação da produção ao gênero estudado na leitura. Parte-se sempre da observação de um determinado gênero, o que ajuda na compreensão por parte do aluno das características linguiísticas e textuais presentes no texto estudado. Há diversidade de gêneros, mas em alguns casos, encontra-se apenas o comando para a produção, sem mencionar qualquer informação a respeito do desenvolvimento temático, do destinatário e do contexto social da escrita. De acordo com o documento:

É necessário também ampliar a oferta de textos para leitura e produção escrita e articular adequadamente os estudos gramaticais com o trabalho proposto com leitura e produção de textos.

http://portal.mec.gov.br/seb/arquivos/pdf/Avalmat/pnld2007_port.pdf 


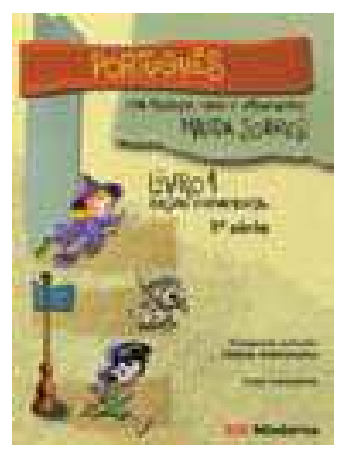

SOARES, Magda Becker. Português: Uma proposta

para o letramento, $1^{\mathrm{a}}, 2^{\mathrm{a}}, 3^{\mathrm{a}}$ e $4^{\mathrm{a}}$ séries.

São Paulo: Moderna, 1999.

A metodologia reflete uma postura construtivista que compreende a aprendizagem como um processo que se desenvolve pela indução e reflexão, sem deixar de orientar os procedimentos no campo da leitura e da produção textual, de acordo com uma concepção de linguagem como prática social, de texto como produto do gênero representativo dessa prática e de língua como um fenômeno em função dos falantes ou da situação de uso.

Em relação à organização, a coleção associa os temas aos gêneros textuais e cada volume apresenta quatro unidades organizadas por uma temática específica, em torno da qual são apresentados gêneros diversos.

A exploração dos aspectos discursivos ocorre com propostas de articulação entre os textos, com a exploração dos sentidos em imagens e com apreciações acerca de temas relativos a valores estéticos, éticos e políticos. Em relação à produção de textos, a coleção apresenta propostas que contemplam gêneros diversos e sempre há uma explicitação ao aluno das condições de produção, principalmente do destino do texto. De acordo com a avaliação do Guia:

A contribuição à organização do texto, à utilização da linguagem adequada ao gênero e à situação comunicativa é também relevante, nesta coleção, graças não apenas à presença, nas atividades de leitura, de modelos do gênero solicitado, mas, sobretudo, ao minucioso trabalho de planejamento para a elaboração dos textos, com atividades de revisão e reelaboração.

http://portal.mec.gov.br/seb/arquivos/pdf/Avalmat/pnld2007_port.pdf 


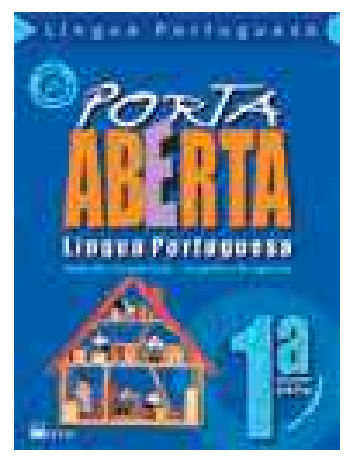

CARPANEDA, Isabella Pessoa de Melo e

BRAGANÇA, Angiolina Domanico.

Porta Aberta: língua portuguesa,

$1^{\mathrm{a}}, 2^{\mathrm{a}}, 3^{\mathrm{a}}$ e $4^{\mathrm{a}}$ séries. São Paulo: FTD, 2005.

A coleção apresenta quatro volumes e os textos não estão reunidos por uma temática comum; o que define a estrutura das unidades é uma sequiência de seções e os conhecimentos lingüísticos são o eixo de ensino privilegiado pela coleção. Este trabalho ora adota uma orientação transmissiva, que oferece regras e definições prontas, ora assume um enfoque teórico metodológico que favorece a reflexão e a construção de conhecimentos.

As atividades de leitura são precedidas de uma conversa com os alunos, com o objetivo de ativar conhecimentos relacionados ao texto a ser lido e propor previsões sobre ele. Depois da leitura, as questões a serem respondidas exigem, predominantemente, localização e reprodução de informações do texto. A partir do volume 2, vão se tornando mais complexas, passando a envolver a compreensão global, a generalização, e, em menor número, a comparação de informações. É o próprio material textual apresentado pela coleção que reduz as possibilidades de um trabalho de leitura crítica e que enfatize a dimensão discursiva, por causa da presença de textos curtos e fragmentados, que, em geral, não se relacionam entre si. A produção de texto é trabalhada de duas maneiras diferentes na coleção: há atividades em que o texto escrito não tem função comunicativa, em que pede-se que o aluno escreva, mesmo sem propósito claro; e há também propostas em que a produção textual é tratada como um processo e orientada para a aprendizagem de procedimentos próprios da escrita, como o planejamento e a revisão. Entretanto, as atividades, mesmo quando enfocam o trabalho com o gênero, são voltadas para o contexto escolar: os interlocutores definidos são os próprios alunos e o destino das produções é o mural da escola. De acordo com o Guia, o trabalho deverá ser complementado pelo professor:

Essa complementação deverá ter o cuidado de oferecer textos integrais, a partir dos quais também se possa propor a exploração do contexto em que foram produzidos e, conseqüentemente, abordar seus aspectos discursivos. Além disso, o professor poderá também intensificar a circulação de bons textos literários em classe. Também será importante propor outras situações de produção de textos que prevejam diversidade de destinatários e circulação externa ao espaço escolar.

http://portal.mec.gov.br/seb/arquivos/pdf/Avalmat/pnld2007_port.pdf 


\section{Exemplos de propostas de produção de texto}

Para realizar este estudo optou-se por analisar as diferentes propostas que constam dos livros que circulam nacionalmente e que possuem grande aceitação por parte dos alunos e dos professores.

Em um primeiro momento, foram analisadas todas as propostas que constavam de cada um dos 28 exemplares que faziam parte da pesquisa. A primeira etapa foi verificar se havia exemplos que confirmavam a hipótese inicial, ou seja, se havia propostas de produção de texto na qual a tarefa seria basear-se em um bom modelo para escrever seu próprio texto. Após esta primeira análise, foram pinçadas algumas propostas de produção de texto que melhor exemplificavam a teoria já exposta anteriormente.

A fim de melhor justificar a escolha, optou-se por expor, de forma resumida, toda a seqüência, que em todas as coleções inclui uma análise textual, para só depois propor a escrita de um texto. Nos livros em que a sequiência apresentou-se muito longa, foram escolhidas apenas algumas etapas do trabalho para ilustrar as idéias propostas pelo autor.

Para as escolhas foi levado em conta se havia relação entre o gênero analisado e o proposto para a escrita, se foi apresentado um modelo de qualidade para o aluno e se havia diferentes categorias de produção de texto, ou seja, propostas para paráfrase/reprodução ou decalque de textos e propostas de autoria, baseando-se no gênero analisado.

A seguir, serão apresentadas as seqüências, divididas por ano e por coleção, seguidas de um breve comentário sobre cada uma delas. Para fins de organização do trabalho, não foram reproduzidas todas as páginas analisadas nas situações em que mostraram-se muito longas. Nesses casos, optou-se por reproduzir as páginas que melhor representavam o trabalho e apresentar a seqüência completa, de forma resumida, na descrição da atividade. 


\section{$2^{\circ}$ ANO / 1 ${ }^{a}$ SÉRIE}

\begin{tabular}{|l|l|}
\hline Autor(es) & $\begin{array}{l}\text { Obra coletiva concebida, desenvolvida e produzida pela } \\
\text { Editora Moderna }\end{array}$ \\
\hline Nome da coleção & Projeto Pitanguá \\
\hline Editora & Moderna \\
\hline Gênero textual & Regras de jogo \\
\hline Páginas analisadas & 181 a 183 \\
\hline
\end{tabular}

\section{Seqüiência para análise textual:}

Apresentação do gênero por meio do texto Passa-anel, retirado da Folha de São Paulo, de 16/04/00, Caderno especial Brincadeiras, p.7. O texto aparece na íntegra, sem cortes a faz parte de uma coletânea de brincadeiras. Encontra-se na $6^{\mathrm{a}}$ unidade do livro, cuja sequiência de diferentes gêneros (poema, conto, texto instrucional, quadrinho) gira em torno de uma temática comum: brincadeiras.

A seqüência analisada parte da leitura do texto, sem nenhum encaminhamento anterior para a discussão de hipóteses ou de conhecimentos prévios e propõe questões de compreensão do texto, com ênfase no entendimento das regras e da estrutura composicional. O objetivo principal das questões é retomar a sequiência das ações propostas para se conseguir brincar, levantando a função social de gêneros como esse.

\section{Seqüência para produção textual:}

Escrita de regras de uma brincadeira ou jogo que a criança conheça.

(Vide figura 1 - 1)

Há um pequeno lembrete para orientar a escrita, chamando a atenção para a presença obrigatória de um título, indicando o nome da brincadeira. Ao final da escrita há orientações para a revisão do texto e indicação do leitor, no caso um colega da sala. 


\section{Comentário:}

A escrita de um texto instrucional, com regras para um jogo ou brincadeira já conhecida, permite que a criança dessa faixa etária possa concentrar-se mais nos aspectos relacionados ao como escrever, uma vez que o que irá escrever já estará decidido. Dessa forma, a categoria de produção de texto acionada será a reprodução/paráfrase, pois o aluno irá basearse no seu repertório para reescrever um texto usando suas palavras.

O fato da estrutura do texto e do conteúdo já estarem definidos retoma as idéias apresentadas durante a fundamentação teórica desta pesquisa: a presença de um modelo a ser seguido acaba por orientar o aluno sobre o que escrever, monitorando seu trabalho.

Na proposta analisada, os alunos são convidados a analisar um exemplo e depois podem basear-se nele para produzir sua própria escrita. Durante a análise, o objetivo é que percebam que há uma seqüência de ações para saber como se brinca e informações sobre como se faz para ganhar o jogo. 


\section{Figura 1 - 1}

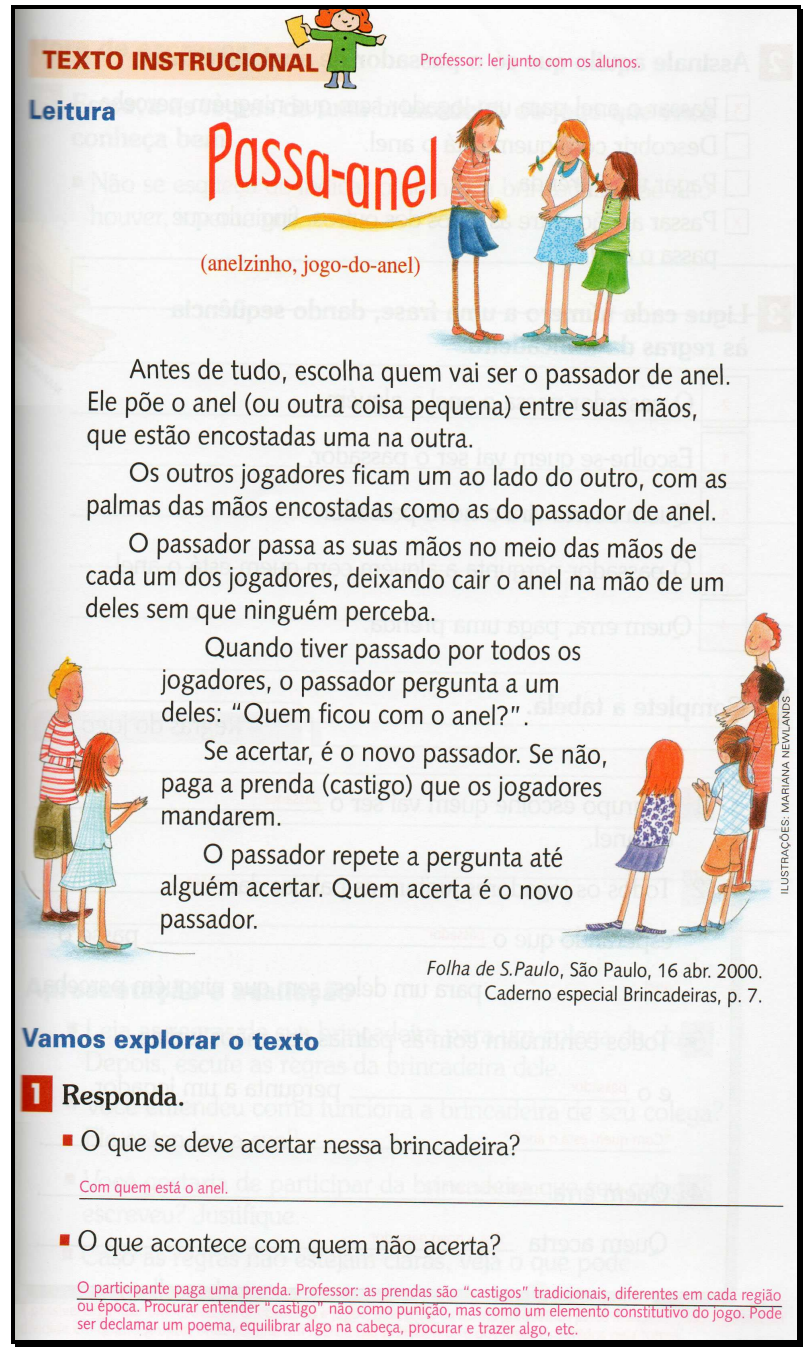

2 Assinale aquilo que só o passador de anel deve fazer.

$凶$ Passar o anel para um jogador sem que ninguém perceba. $\square$ Descobrir com quem está o anel.

$\square$ Pagar uma prenda.

$凶$ Passar a mão entre as mãos dos outros, fingindo que passa o anel.

3 Ligue cada número a uma frase, dando seqüência às regras da brincadeira.
2 O passador passa o anel a alguém.
Escolhe-se quem vai ser o passador.
Quem acerta vira o novo passador.
O passador pergunta a alguém com quem está o anel.
${ }_{4}$ Quem erra, paga uma prenda.

4 Complete a tabela.

\section{Regras do jogo}

1 O grupo escolhe quem vai ser o passador do anel.

2 Todos os jogadores juntam as palmas das mãos esperando que o passador passe 0 anel para um deles, sem que ninguém perceba

3 Todos continuam com as palmas das mãos juntas, e o passador pergunta a um jogador "Com quem está o anel?"

4 Quem erra paga uma prenda

Quem acerta vira novo passador 


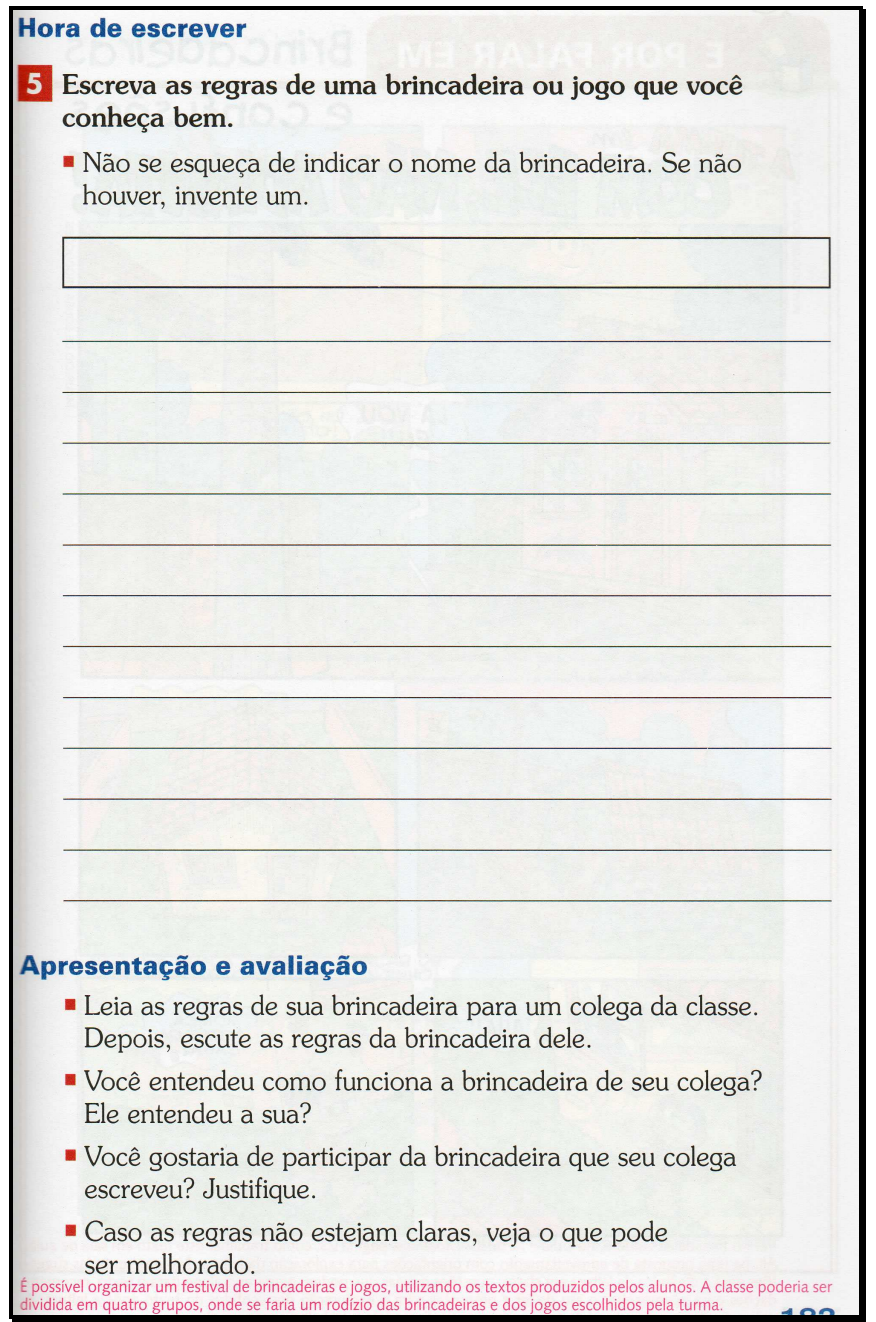




\begin{tabular}{|l|l|}
\hline Autor(es) & William R. Cereja e Thereza C. Magalhães \\
\hline Nome da coleção & Português: linguagens \\
\hline Editora & Atual \\
\hline Gênero textual & Texto de instruções de montagem \\
\hline Páginas analisadas & 105 a 109 \\
\hline
\end{tabular}

\section{Sequiência para análise textual:}

Apresentação do gênero por meio de uma história em quadrinhos com instruções para montar uma pipa, retirada da Revista do Maluquinho, $\mathrm{n}^{\circ}$ 4, p.16-7. As atividades fazem parte da unidade 2, cujo tema são as brincadeiras e os brinquedos.

As questões propostas retomam outros textos do mesmo gênero já lidos nas páginas anteriores, estabelecendo relações entre eles a fim de que os alunos percebam sua principal função: ensinar algo por meio de instruções. Há também questões de compreensão, com ênfase no entendimento das regras e na retomada da seqüência das ações propostas.

\section{Seqüência para produção textual:}

Escrita de instruções para a construção de um brinquedo que a criança conheça. É apresentado um roteiro para apoio da escrita, cuja primeira orientação é a produção de desenhos em quadrinhos, mostrando passo a passo como se monta o brinquedo. Só depois os alunos irão escrever o texto, embaixo dos quadrinhos. Além da indicação da avaliação do próprio texto são explicitados os leitores, que no caso, são os próprios colegas da sala.

(Vide figura 1 - 2) 


\section{Comentário:}

Novamente, a escrita de um texto instrucional permite que as decisões sobre o que escrever já estejam definidas. Os alunos irão produzir o seu texto a partir de uma descrição de ações já conhecidas por eles.

No caso da proposta analisada, a escrita é apoiada por desenhos, permitindo que os alunos dessa faixa etária possam valer-se de outros recursos para organizar as idéias. Dessa forma, acabam concentrando-se mais em como escrever, uma vez que ainda estão em processo de alfabetização. A escolha das letras e da forma de organizar as informações passa a ser o foco do trabalho.

Um outro aspecto que merece atenção, e que também reflete as escolhas feitas pelos alunos, é a capacidade de selecionar as informações mais significativas para colocar no seu texto, de forma que seja compreendido por quem lê e que esse leitor consiga realizar a tarefa descrita.

Trata-se de uma proposta cujo fazer é direcionado e o aluno não é levado a produzir sem uma referência, um caminho. A tarefa tornou-se mais facilitada com as orientações e com os modelos apresentados anteriormente. 


\section{Figura 1 - 2}

1. O ideal é soltar pipa num lugar amplo, aberto, sem trânsito, postes e fios elétricos. Na cidade de São Paulo, chegaram a criar um "pipódromo" para as crianças se divertirem.

a) Na sua cidade, existe um "pipódromo"? Se sim, onde ele fica?

b) Na sua opinião, por que é importante haver "pipódromos" nas grandes cidades?

2. Algumas crianças passam cerol ou cortante na linha, para cortar a linha de outras pipas. O cerol é feito com uma mistura de cola, vidro, ferro ou alumínio moído. Por causa desses produtos, a linha pode machucar e, quando enrosca em fios elétricos, pode dar um choque capaz de matar uma pessoa.

a) Na sua opinião, as crianças devem soltar pipas com cerol? Por quê?

b) O que a criança deve fazer quando alguém tenta cortar a linha da pipa que ela está soltando?

\section{Produção de texto}

\section{TEXTO DE INSTRUÇŌES DE MONTAGEM}

1. No capítulo anterior, você viu que o texto "Boca-de-Forno" é instrucional porque ensina as regras dessa brincadeira. "Artes maluquinhas" também é um texto instrucional, porque também dá instruções. No caso do texto "Artes maluquinhas", o que ele ensina a fazer ou a montar?
2. O texto do Menino Maluquinho foi escrito em forma de história em quadrinhos. Por que você acha que o autor escolheu um texto com essa forma para ensinar a fazer pipa? Marque a melhor resposta:

$\square$ Porque as crianças só sabem ler histórias em quadrinhos.

凶 Porque, na forma de história em quadrinhos, fica mais gostoso de ler e mais fácil de compreender as instruções.

$\square$ Porque todos os textos instrucionais são redigidos como histórias em quadrinhos.

3. Observe as instruções a seguir, dadas para a montagem da pipa:

"corte duas das varetas"

"forme uma cruz"

"coloque a última vareta"

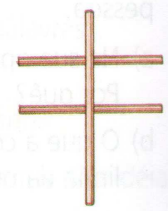

Indique outras ações que o leitor deve realizar para montar a pipa.

amarre as varetas; dê muitas voltas; faça um cortezinho; etc

4. No texto, cada fala do Menino Maluquinho é acompanhada de uma figura, que mostra como ele está fazendo a pipa. Para que servem as figuras? Marque a resposta que, na sua opinião, é a melhor:

$\square$ Servem principalmente para divertir o leitor.

Х Servem principalmente para ajudar o leitor a compreender melhor o texto

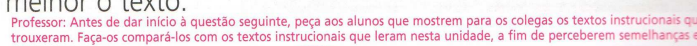




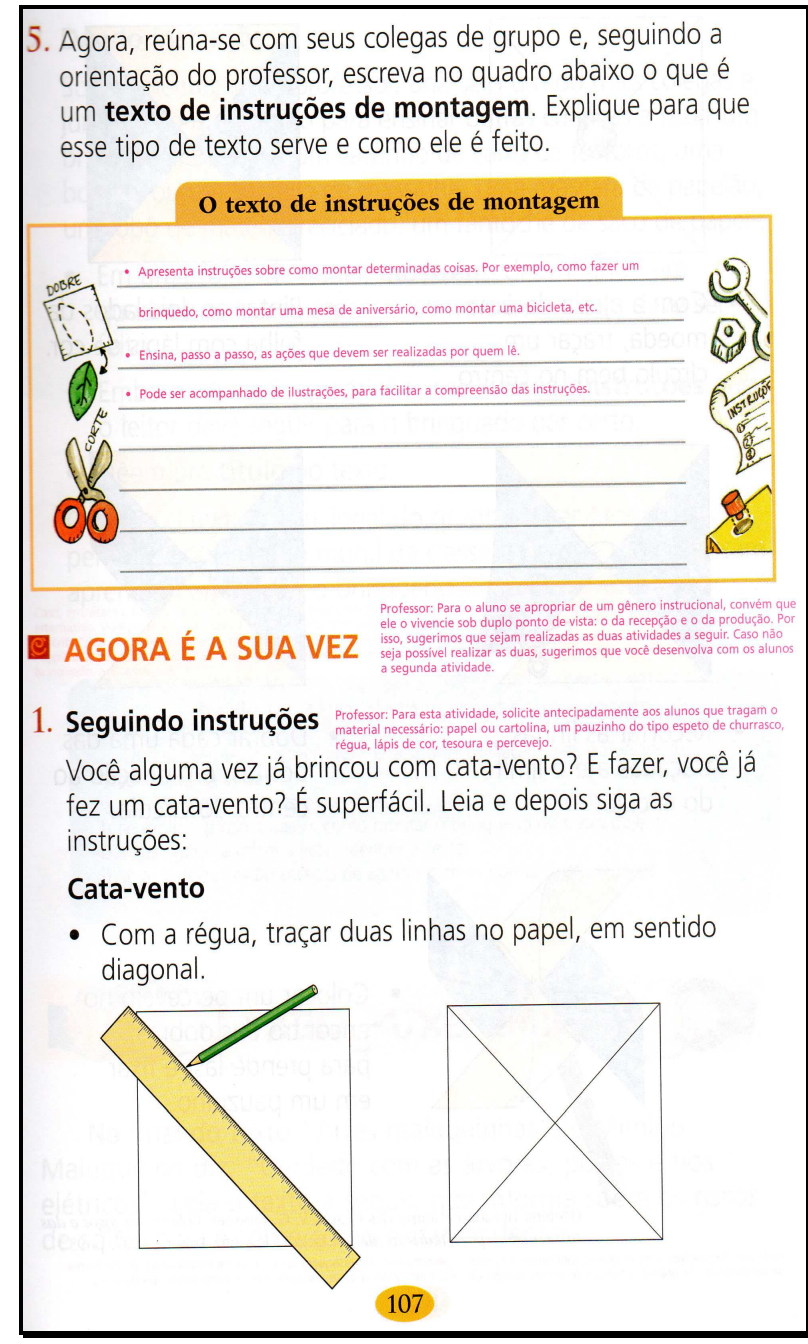

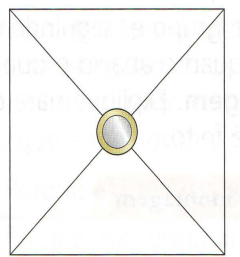

- Com a ajuda de uma moeda, traçar um círculo bem no centro.

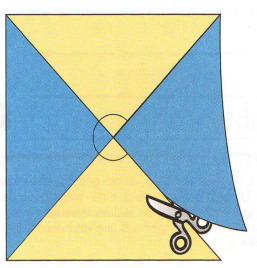

- Recortar as linhas traçadas até o limite do círculo.

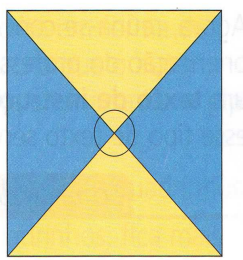

- Pintar os dois lados da folha com lápis de cor.

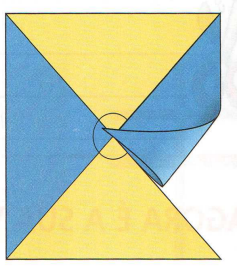

- Dobrar cada uma das pontas, em direção ao centro do círculo.

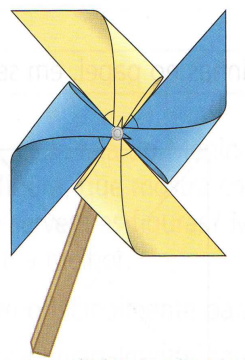

- Colocar um percevejo no encontro das dobras, para prendê-las, e fixar em um pauzinho.

Helena Brandão e Maria das Graças V G. Froesler. O livro dos jogos e dos brincadeiras para todas as idades. Belo Horizonte: Leitura, 1997. p. 93.)

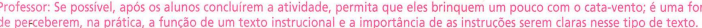




\section{Dando instruções}

Sob a orientação do professor, una-se a um ou mais colegas e, juntos, criem um texto para ensinar outras crianças a fazer um brinquedo. Pode ser um carrinho de caixa de fósforos, uma boneca ou um boneco de massinha, uma máscara de papelão, um robô de material reciclado, um fantoche de saco de papel..

- Em uma folha de papel, mostrem, desenhando em quadrinhos, passo a passo, como o brinquedo deve ser feito.

- Embaixo de cada quadrinho, escrevam as instruções que o leitor deve seguir para o brinquedo dar certo.

- Dêem um título ao texto.

Quando o texto instrucional do grupo estiver pronto, pendurem a folha no mural da classe para que todos possam aprender como fazer o brinquedo. Professor: Sugerimos montar duplas de tal modo que

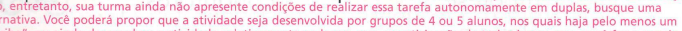

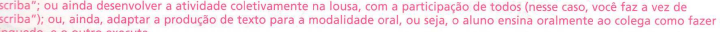

Avalie seu texto de instruções de montagem Quando seu texto estiver pronto, faça uma avaliação dele, observando: 1) se apresenta título;

materiais necessários para fazer o brinquedo

so a passo, como montar o brinquedo ou outro objeto;

compreender o texto:

5) se as palavras estäo escritas de acordo com as normas ortográficas.

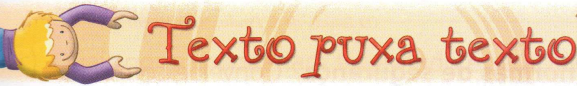

No final do texto "Artes maluquinhas", o Menino Maluquinho diz: "Cuidado com as árvores, postes e fios elétricos". Leia o texto a seguir, que informa sobre os riscos de soltar pipa e sobre como evitar acidentes. 


\begin{tabular}{|l|l|}
\hline Autor(es) & $\begin{array}{l}\text { SIMONCELLO, Vera Lucia, } \\
\text { ORCHIS, Amália e CHU, Angelina V. de Andrade. }\end{array}$ \\
\hline Nome da coleção & Registrando descobertas: língua portuguesa \\
\hline Editora & FTD \\
\hline Gênero textual & Conto de fadas \\
\hline Páginas analisadas & 95 a 98 \\
\hline
\end{tabular}

\section{Seqüência para análise textual:}

A seqüência proposta encontra-se na unidade 2 do livro, cujo tema é fantasia e realidade. Há uma remissão ao texto anterior, que é um poema, para a apresentação do gênero que será produzido. No caso, são animais que se referem ao conto clássico da Branca de Neve. Uma versão dessa história, escrita pelos próprios autores do livro didático, encontra-se no Manual do professor e será lida aos alunos. Estes não terão o texto para acompanhar e entrarão em contato com o conto somente pela audição. Por ser uma história conhecida, provavelmente já a terão ouvido e poderão remeter-se a estes outros modelos com os quais já tenham tido contato. As questões de entendimento abordam a estrutura dos contos, fazendo com que os alunos identifiquem título, cenários, protagonistas, antagonistas da história e os acontecimentos mais importantes.

\section{Seqüência para produção textual:}

A proposta prevê a reprodução/paráfrase, em dupla, do conto da Branca de Neve. Antes de reescrevê-lo, alguns alunos deverão recontá-lo oralmente para a classe. Depois, há uma proposta para avaliar o próprio trabalho e uma sugestão para alterar no texto o que acharem significativo.

(Vide figura 1 - 3) 


\section{Comentário:}

A categoria proposta, a reprodução/paráfrase, demonstra ser adequada neste momento devido a dois fatores principais: a especificidade do gênero e o momento de aprendizagem que os alunos se encontram.

O conto de fadas é um gênero complexo, que apesar da sua estrutura fixa, contém muitos detalhes e muitas características incomuns, tais como elementos mágicos, presença de elementos do bem e do mau, um conflito emocionante etc. Além disso, é preciso levar em conta o momento de aprendizagem que as crianças se encontram: por ser um livro de $1^{\mathrm{a}}$ série e por essa atividade estar sendo proposta para o primeiro semestre, pois encontra-se na $2^{\mathrm{a}}$ unidade em um livro que apresenta 4 blocos, é esperado que as crianças ainda tenham muitas dúvidas em relação à escrita, pois ainda estão em processo de aquisição do sistema alfabético.

Por esses motivos, acaba sendo difícil, para uma criança dessa faixa etária, concentrarse em muitos aspectos, ou seja, decidir sobre o que e como escrever. A reprodução/paráfrase acaba sendo uma forma de ajudá-la a escrever melhor, pois o que escrever já estará posto, cabendo a ela organizar a história com as suas palavras. Esse fato também incentiva a criação, pois não se trata de uma cópia, uma transcrição literal do conto. Há esforço do sujeito nisso: caberá a ele definir as partes que serão reproduzidas e escolher o melhor jeito de contá-las, recontando a história a seu modo. 
Figura 1 - 3

\section{Espaço de criação}

1. No poema $O$ espelho e a perua, a galinha carijó e a perua falam sobre o conto de fadas Branca de Neve e os sete anões.
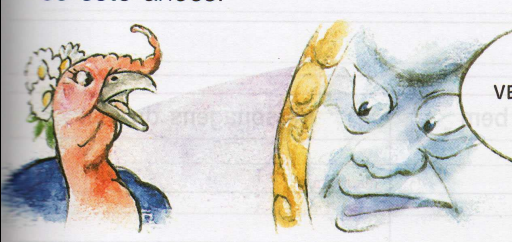
ERDADE, VOU DIZÊ-LA NUA E CRUA.

Agora, seu professor vai contar a história Branca de Neve e os sete anões. Ouça com atenção!

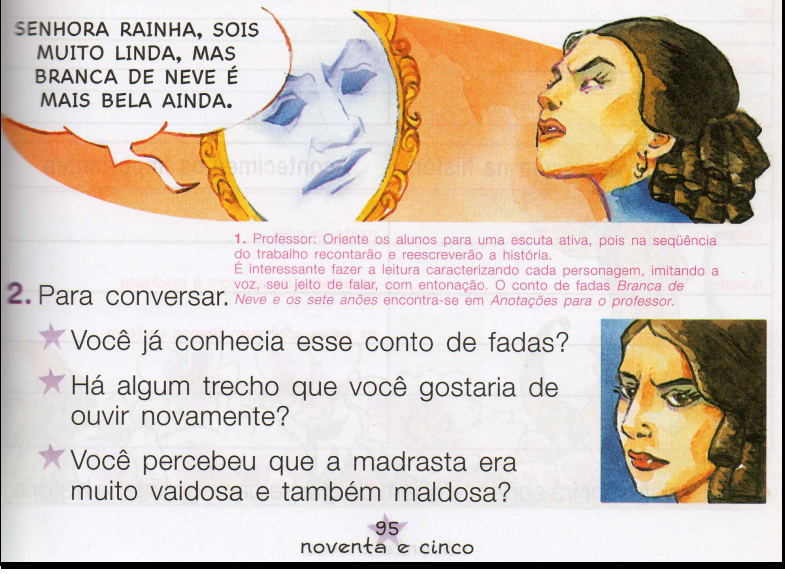

3. Preencha o quadro com as informações mais importantes

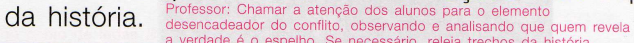

\section{Título}

Branca de Neve e os sete anōes

\section{Quando aconteceu essa história}

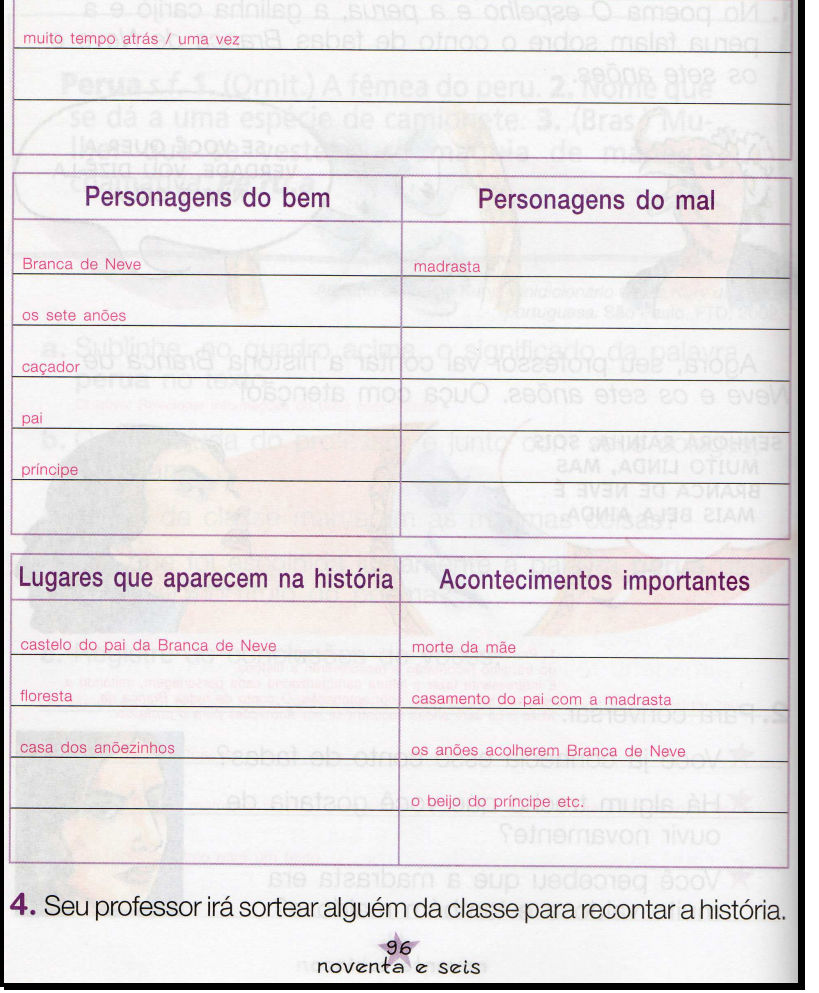




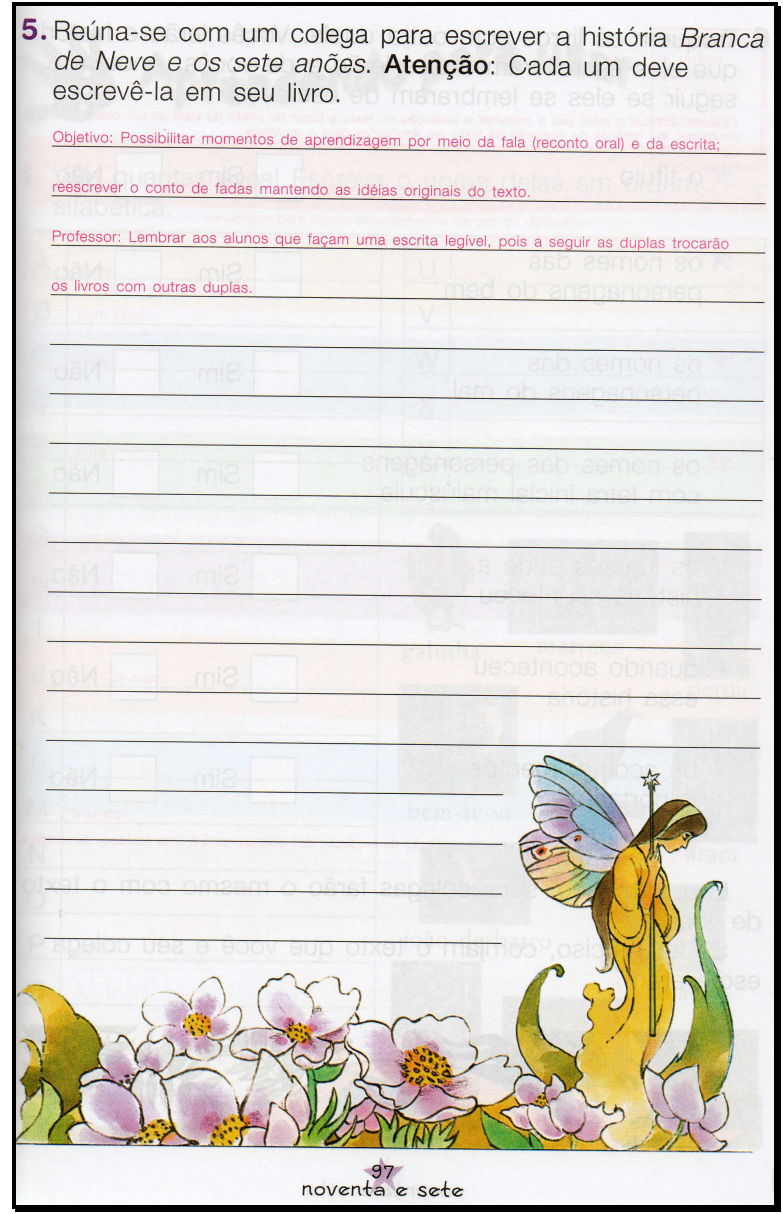

6. Troquem os livros com outra dupla. Vocês lerão a história que eles escreveram e eles lerão a de vocês. Anotem a seguir se eles se lembraram de escrever:

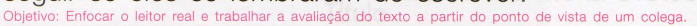

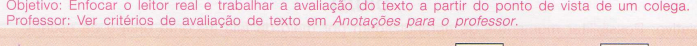

* título
* $\begin{aligned} & \square \text { Sim nomes das } \\ & \text { personagens do bem }\end{aligned}$
Não
os nomes das
personagens do mal

Enquanto isso, seus colegas farão o mesmo com o texto de vocês.

Se for preciso, corrijam o texto que você e seu colega escreveram.

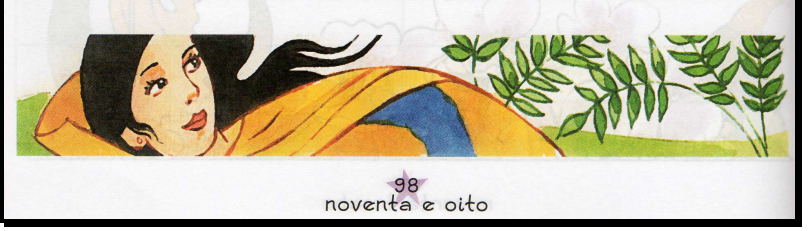




\begin{tabular}{|l|l|}
\hline Autor(es) & $\begin{array}{l}\text { PANACHÃO, Débora, CARVALHO, Carmen Silvia Cintra } \\
\text { Torres, KUTNIKAS, Sarina Bacellar, SALMASO, Silvia } \\
\text { Maria de Almeida e BARALDI, Maria da Graça Barreto. }\end{array}$ \\
\hline Nome da coleção & Construindo a escrita \\
\hline Editora & Ática \\
\hline Gênero textual & Conto de fadas \\
\hline Páginas analisadas & 10 a 24 \\
\hline
\end{tabular}

\section{Seqüência para análise textual:}

A sequiência proposta é a primeira atividade de análise e de produção de texto proposta no livro, que compreende 13 textos no total, para serem trabalhados durante o ano. Trata-se do conto da Bela Adormecida, na sua versão original, apenas traduzido para o português. Foi retirado do livro Contos de Grimm, traduzido por Heloisa Penteado e publicado pela editora Ática, em 1999. O foco do trabalho é a comparação de diferentes versões desse conto que, apesar de manter sua estrutura fixa, apresenta uma grande variação no que se refere aos detalhes, às descrições, aos fatos e a alguns trechos que foram suavizados pelas versões de Walt Disney. O livro apresenta o texto original e sugere que os alunos leiam outras versões desse mesmo conto para que possam efetuar as comparações.

\section{Sequiência para produção textual:}

A proposta prevê a reprodução/paráfrase do conto, incentivando os alunos a contarem a história do seu jeito.

(Vide figura 1 - 4) 


\section{Comentário:}

Novamente, a categoria proposta, a reprodução/paráfrase, demonstra ser adequada neste momento devido a dois fatores principais: a especificidade do gênero e o momento de aprendizagem que os alunos se encontram. $\mathrm{O}$ conto de fadas é um gênero cujas histórias são recontadas por vários autores e há uma inúmera quantidade de versões diferentes circulando e, provavelmente, os alunos já conhecerão muitas delas.

Dessa forma, será esperado que já tenham tido contato com uma série de modelos para se apoiar e poderão escrever do seu jeito, já que uma mesma história pode ser contada de diferentes maneiras.

A reprodução/paráfrase é uma forma de exercer a autoria a partir de um modelo, pois não se trata de copiar o texto exatamente como ele é, mas de reproduzi-lo usando suas próprias palavras, ou seja, escrevendo do seu jeito. Apesar de acontecerem coisas semelhantes nas histórias lidas e produzidas por tratar-se de um mesmo conto clássico, a forma de contar, ou seja, os detalhes sobre as cenas e sobre as personagens serão diferentes. A linguagem utilizada também irá variar de acordo, por exemplo, com a época em que o conto foi produzido, pois poderá haver nos contos originais palavras desconhecidas que hoje em dia não sejam tão usuais. 
Figura 1 - 4

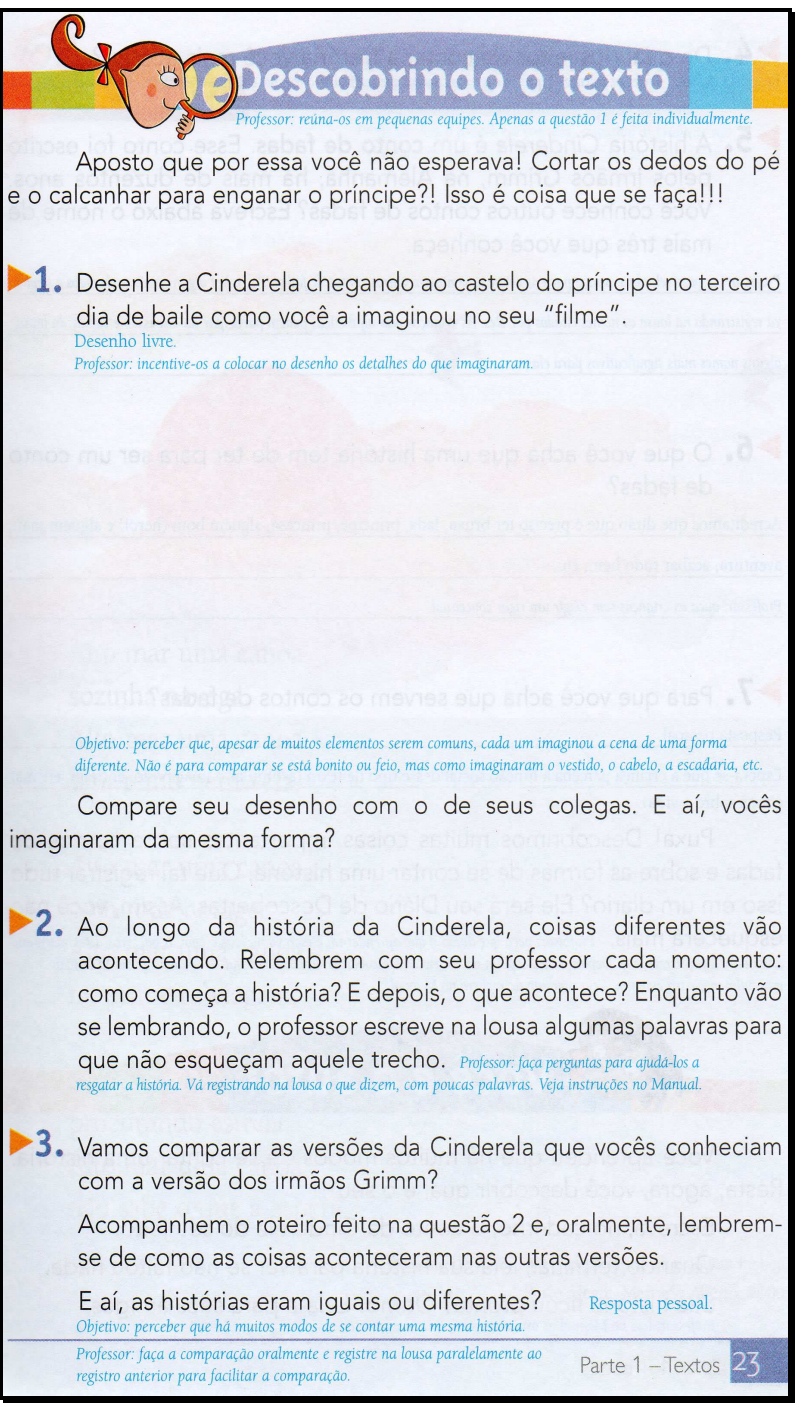

2. Ao longo da história da Cinderela, coisas diferentes vão acontecendo. Relembrem com seu professor cada momento: que não esqueçam aquele trecho. Professor faca perguntas para ajuda-los a

Vamos comparar as versões da Cinderela que vocês conheciam com a versão dos irmãos Grimm?

se de como as coisas aconteceram nas outras versões.

E aí, as histórias eram iguais ou diferentes?

Professor: faça a comparaçāo oralmente e registre na lousa paralelamente ao Parte 1 - Textos
4. De qual dos jeitos de contar a história você mais gostou?

5. A história Cinderela é um conto de fadas. Esse conto foi escrito pelos irmãos Grimm, na Alemanha, há mais de duzentos anos. Você conhece outros contos de fadas? Escreva abaixo o nome de mais três que você conheça.

Professor: se possivel, abra espaco para as criancas contarem outros contos de fadas. Relembre alguns mais conhecidos e depois và registrando na lousa os nomes citados por eles. As criancas näo-alfabeticas podem participar da discussào e copiar da lousa. alguns nomes mais significativos para elas.

6. O que você acha que uma história tem de ter para ser um conto de fadas?

Acreditamos que dirão que é preciso ter bruxa, fada, príncipe, princesa, alguém bom (herói) e alguém mau aventura, acabar tudo bem, etc.

Professor: ouca as criancas sem exigir um rigor conceitual.

7. Para que você acha que servem os contos de fadas? Resposta pessoa

Espera-se que a criança perceba a função social desse tipo de texto (estimular o imaginário, entreter, ensinar Puxa! Des

cobrimos muitas coisas importantes sobre contos de fadas e sobre as formas de se contar uma história. Que tal registrar tudo isso em um diário? Ele será seu Diário de Descobertas. Assim, você não esquecerá mais. Professor: peca que ditem o que aprenderam e escreva na lousa, com as palavras deles, para que prendam a azer registros. Depois, todos copiam no Diâno de Descobertas, um caderno que as criancas poderào ứlizar arendam a fazer registros. Depois, todos copiam no Diário de De

\section{Tơ vocé é autor}

Você aprendeu que há muitos modos de se contar uma história. Resta, agora, você descobrir qual é o seu!!!

Escreva, no caderno, o conto da Cinderela do seu jeito.

Quando terminar, leia sua história para ver se não faltou nada.

Sua história ficou pronta? Ótimo! Leia-a para seus amigos.

4 Parte 1 - Textos 


\begin{tabular}{|l|l|}
\hline Autor & SOARES, Magda Becker \\
\hline Nome da coleção & Português: Uma proposta para o letramento \\
\hline Editora & Moderna \\
\hline Gênero textual & Definição \\
\hline Páginas analisadas & 14 a 17 \\
\hline
\end{tabular}

\section{Seqüência para análise textual:}

O texto escolhido para análise é o $2^{\circ}$ gênero apresentado da unidade 1 do livro, cujo tema é a escola. Por tratar-se de uma coleção temática, são apresentados vários gêneros dentro de um mesmo tema e para cada um deles há uma sequiência para a análise e para a produção, cujas atividades são tanto orais quanto escritas.

O trabalho inicia-se com uma pergunta sobre o que é a escola e com a apresentação de várias definições sobre o tema, retiradas de diversas fontes (Dicionário Aurélio infantil da língua portuguesa, Editora Nova Fronteira, 1989, p. 80; trecho do texto de José Paulo Paes, publicado na Folhinha de 8/11/77, p. 10; Dicionário de humor infantil, escrito por Pedro Bloch e publicado pela Ediouro, em 1997, p. 63). As perguntas de interpretação levam os alunos a perceberem que dependendo do objetivo do texto a definição apresentada será diferente.

\section{Sequiência para produção textual:}

A proposta prevê a escrita da sua própria definição acerca do que é a escola. Além dos modelos já apresentados para análise, são apresentadas mais três definições bem espontâneas, elaboradas por crianças de 6, 9 e 12 anos. São textos que utilizam uma linguagem coloquial, bem diferenciada da definição presente no dicionário.

(Vide figura 1 - 5) 


\section{Comentário:}

A proposta leva em conta os modelos apresentados para que os alunos tenham informações sobre como escrever, mas incentiva os aprendizes a escreverem seus próprios textos com a definição sobre o que é a escola, segundo seu próprio ponto de vista.

Ao usarem suas próprias palavras, poderão colocar em prática seus conhecimentos sobre o gênero definição, cujo objetivo é dar o significado de uma palavra, juntamente com um exemplo em que essa palavra é empregada em uma frase.

A definição sobre o que é a escola não possibilita textos muito diferentes, porém, dependendo do ponto de vista de cada um e da linguagem utilizada, cada aluno irá registrar a sua própria definição sobre o tema em questão. Podem optar por uma definição mais formal, como a do dicionário, mais engraçada, como a do dicionário com humor ou mais informal, como a escrita pelas crianças. Em todos os casos estarão reproduzindo um dos modelos, porém com a sua própria linguagem. 
Figura 1 - 5

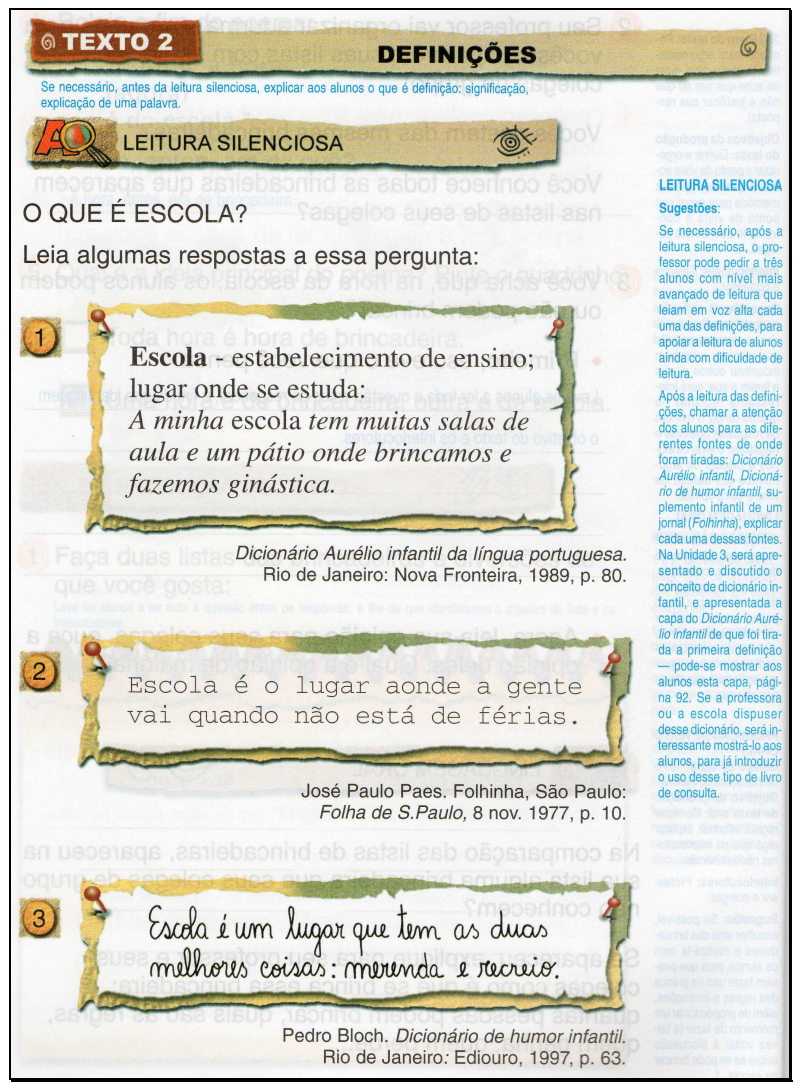

(x)

Q2) INTERPRETAÇÃO ESCRITA

(1) O que as definições dizem da escola? Escreva nos quadrinhos o número da definição correspondente:

Definição que diz o que é MESMO a escola: 1

Definição que fala das coisas boas da escola:

Definição que diz quando a gente vai à escola:

(2) A definição (1) apresenta um exemplo de uso da palavra escola. Veja:

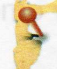

Escola - estabelecimento de ensino; lugar onde se estuda:

A minha escola tem muitas salas de aula e um pátio onde brincamos e fazemos ginástica.

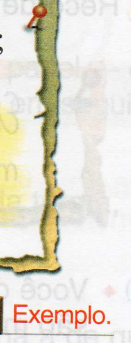

- Escreva um outro exemplo de frase com a palavra escola - diga o que a sua escola tem.

Resposta pessoal. 


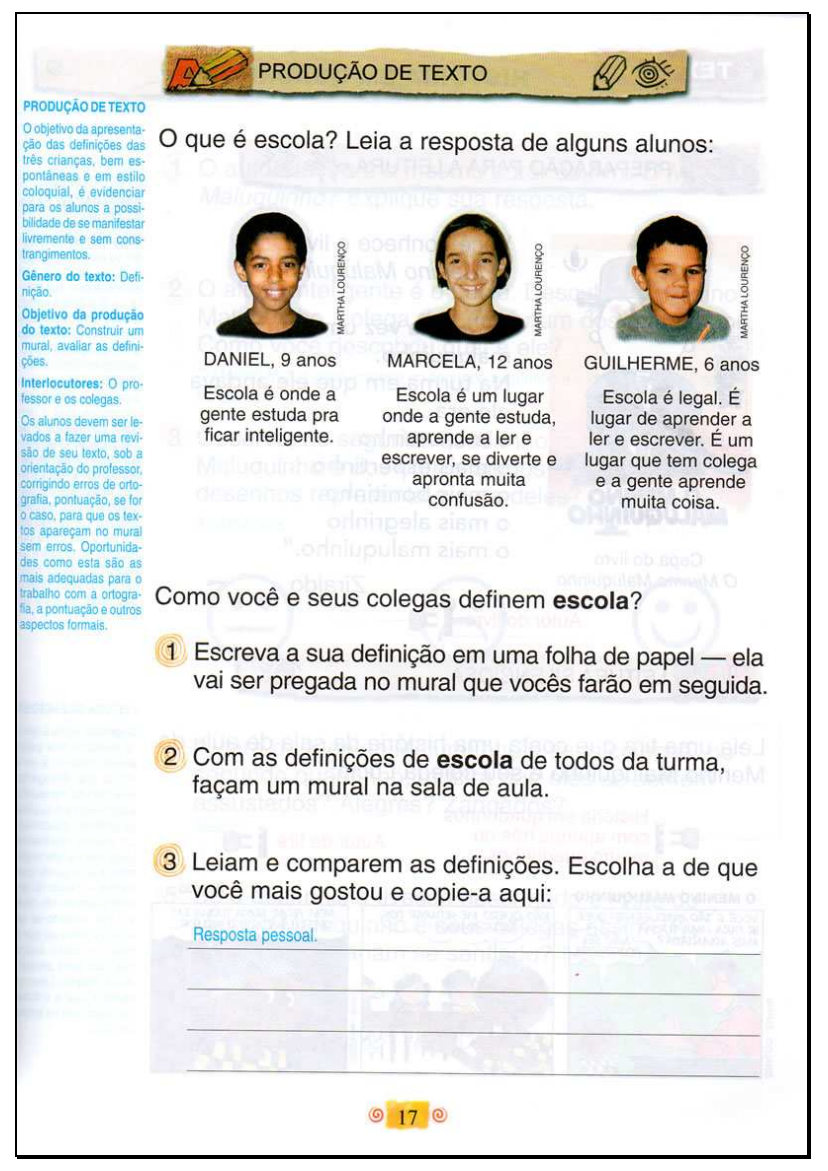




\begin{tabular}{|l|l|}
\hline Autor(es) & $\begin{array}{l}\text { CARPANEDA, Isabella Pessoa de Melo e BRAGANÇA, } \\
\text { Angiolina Domanico }\end{array}$ \\
\hline Nome da coleção & Porta Aberta: língua portuguesa \\
\hline Editora & FTD \\
\hline Gênero textual & Fábula \\
\hline Páginas analisadas & 57 a 66 \\
\hline
\end{tabular}

\section{Seqüência para análise textual:}

A fábula é o gênero escolhido para análise e aparece na quarta unidade do livro, dentre as quinze unidades apresentadas. Os textos utilizados para desenvolver o trabalho são A esperteza da raposa e A cigarra e a formiga, fábulas de Esopo, recontadas pelas autoras do livro didático. As perguntas retomam o entendimento dos textos e iniciam uma análise sobre as características do gênero no que se refere às personagens mais comuns, ou seja, presença de animais com comportamentos humanizados e de uma moral, um ensinamento no final.

\section{Seqüência para produção textual:}

A proposta de produção de texto orienta a reprodução da fábula lida. Por ainda estarem em um processo de aquisição da escrita, os alunos farão o texto em grupo, tendo o professor como escriba.

A turma deverá escolher qual o final que darão para a fábula A cigarra e a formiga, pois foram lidas duas versões com finais diferentes. Há também orientações para a revisão do texto, auxiliando os alunos na organização da estrutura dessa narrativa e no encadeamento dos fatos.

(Vide figura 1 - 6) 


\section{Comentário:}

A reprodução/paráfrase é uma categoria adequada para o trabalho com as fábulas, pois é um gênero que apresenta características peculiares e inferências sobre seu conteúdo, que podem se tornar um dificultador nos momentos de escrever. Por exemplo, é um gênero em que as personagens possuem comportamentos tipicamente humanos, mas não se trata de qualquer animal, há uma relação entre as suas características e o comportamento que lhe é atribuído: uma raposa é sempre a personagem esperta, traiçoeira etc. A moral que o texto transmite também exige uma capacidade de síntese por parte dos alunos que, sozinhos, teriam muita dificuldade para produzir. Portanto, a proposta de reprodução/paráfrase da fábula permite que os alunos possam basear-se em um modelo para escrever a sua versão, usando suas palavras e escolhendo a melhor forma de organizá-la.

Aprender a escrever é aprender a reescrever. É importante oferecer aos alunos várias oportunidades de reproduzir textos ora sozinhos, ora de forma compartilhada. Tendo o professor como escriba, também é possível percebê-lo como um modelo para os alunos, pois ele ajuda a recuperar a ordem seqüencial dos fatos, a ajustar o oral ao escrito, transformando o que foi dito em algo que será escrito, com reflexões, por exemplo, sobre qual pontuação usar ou sobre qual a melhor forma de organizar os parágrafos. 
Figura 1 - 6

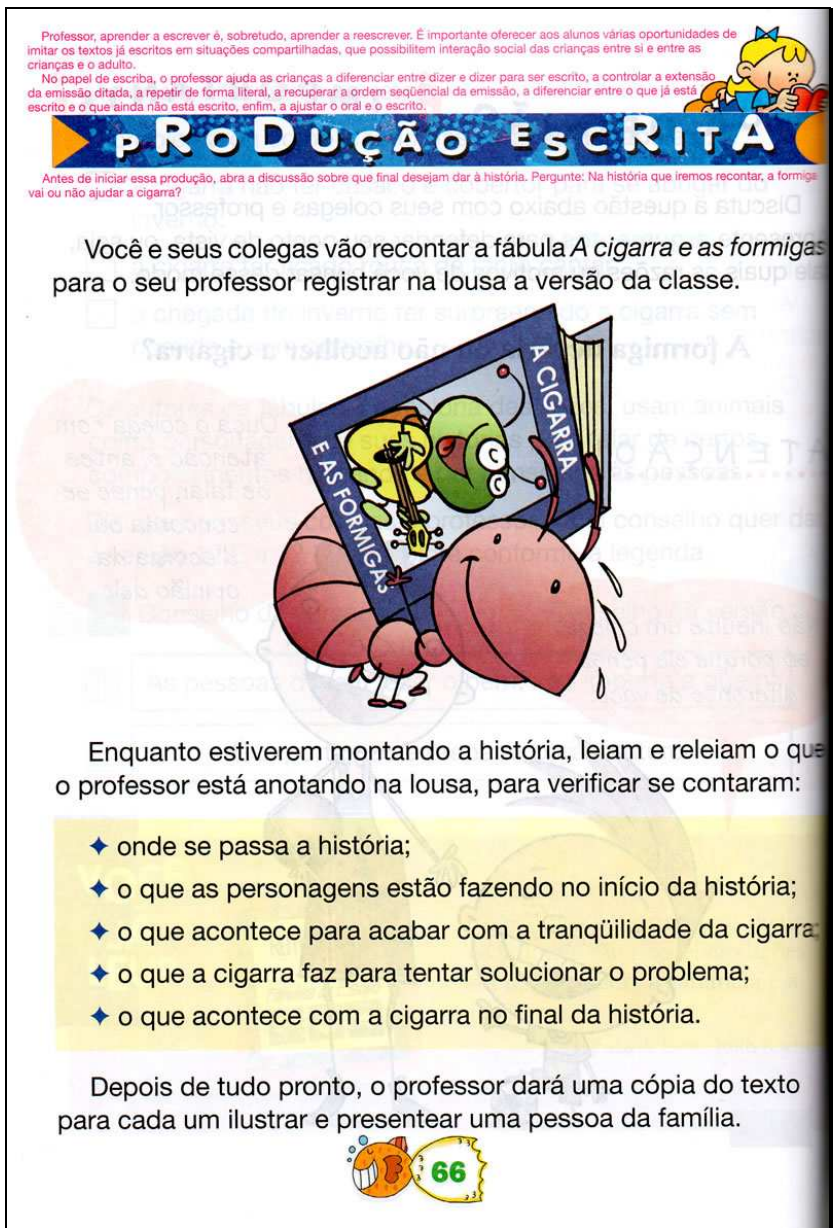




\begin{tabular}{|l|l|}
\hline Autor(es) & $\begin{array}{l}\text { Obra coletiva concebida, desenvolvida e produzida pela } \\
\text { Editora Moderna }\end{array}$ \\
\hline Nome da coleção & Projeto Pitanguá \\
\hline Editora & Moderna \\
\hline Gênero textual & Ficha descritiva \\
\hline Páginas analisadas & 15 e 16 \\
\hline
\end{tabular}

\section{Sequiência para análise textual:}

Em um primeiro momento os alunos irão ler e analisar um pequeno texto com uma auto-biografia fictícia de uma personagem criada por Carlos Queiroz Telles e que consta do livro Asas Brancas, publicado pela editora Moderna, em 2002, p. 6 a 8 . O texto encontra-se no início do livro e faz parte de uma sequência cujo objetivo é incentivar a integração dos alunos, devido à época do ano e promover o conhecimento de personagens, reais ou fictícias, por meio da leitura de biografias e de auto-biografias.

A partir da leitura do texto, as questões de entendimento visam a reflexão sobre o vocabulário empregado e o uso de expressões mais coloquiais e uma linguagem mais informal. Para isso, deverão realizar inferências para construir o sentido do texto. A última parte da análise proposta, orienta um exercício de síntese, em que os alunos deverão preencher uma ficha descritiva com informações sobre a personagem, e para isso, deverão localizar as respostas no texto lido.

\section{Sequiência para produção textual:}

A proposta de produção de texto prevê a escrita de uma ficha descritiva do próprio aluno, com itens sugeridos pelos autores a partir do texto analisado. Não se trata de um texto em parágrafos, mas de uma tabela com itens a serem respondidos pelos alunos sobre sua vida.

(Vide figura 2 - 1) 


\section{Comentário:}

A escrita da ficha permite que os alunos concentrem-se parte em como escrever e parte em o que escrever, uma vez que se trata de uma ficha com descrições de si próprio.

Inicia-se um processo de autoria, porém as informações já estão pré-determinadas e caberá ao aluno organizá-las. Essa ajuda orienta a escrita, indicando o que escrever sobre si mesmo.

Dessa forma, poderão apoiar-se em um modelo para escrever, ao mesmo tempo em que podem exercer sua autoria.

A concentração na escrita ocorrerá na escolha das palavras para sintetizar seu jeito de ser e na escolha dos itens que melhor traduzirão sua personalidade, pois os alunos também poderão ampliar ou reduzir os dados presentes na tabela. 
Figura 2-1
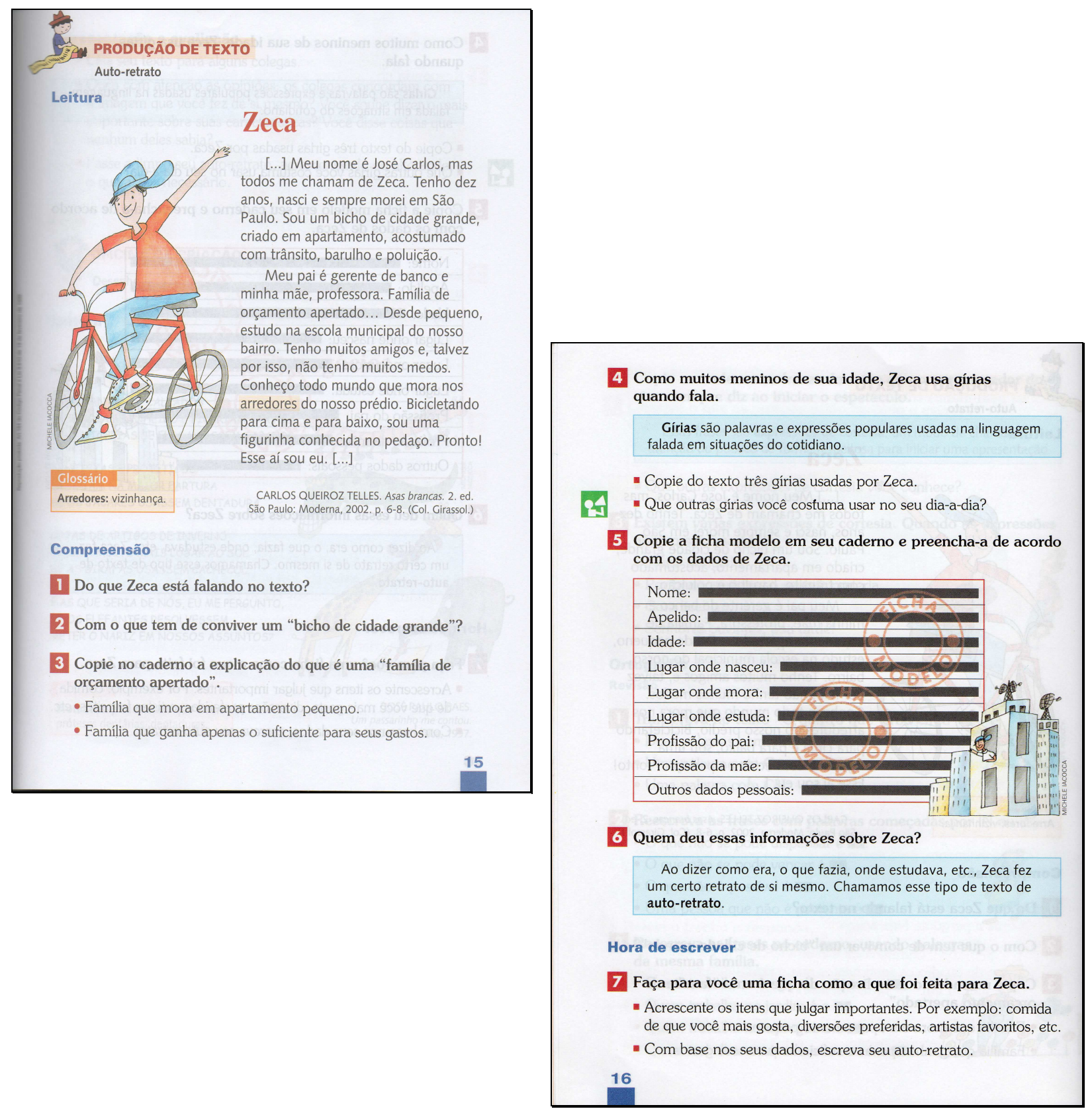


\begin{tabular}{|l|l|}
\hline Autor(es) & William R. Cereja e Thereza C. Magalhães \\
\hline Nome da coleção & Português: linguagens \\
\hline Editora & Atual \\
\hline Gênero textual & Carta pessoal \\
\hline Páginas analisadas & 23 a 29 \\
\hline
\end{tabular}

\section{Seqüência para análise textual:}

Apresentação do gênero por meio de uma carta fictícia, elaborada pelos autores do livro, sobre um garoto contando ao avô sobre sua festa de aniversário. Trata-se de um texto que faz parte de uma unidade cujo tema é a criança.

As questões enfocam a estrutura composicional do texto, levantando suas principais características, tais como: definição de quem é o remetente e quem é o destinatário, localização da saudação, local, data, assunto e despedida. No final, é proposta a análise e a escrita do envelope.

Há também aspectos relacionados à linguagem empregada, chamando a atenção para o fato de que em uma carta pessoal, escrita por uma criança, é possível empregar-se uma linguagem mais informal.

No final, a proposta retoma as características do gênero ao completar, coletivamente, um quadro com as descobertas feitas.

\section{Seqüência para produção textual:}

É proposta a escrita de uma carta pessoal para um destinatário conhecido, a partir de assuntos sugeridos pelos autores, como por exemplo: escrever para indicar livros ou revistas interessantes, comentários sobre coleções ou animais de estimação, programas de TV favoritos etc, ou seja, assuntos de interesse do universo infantil, uma vez que os destinatários serão os próprios colegas.

(Vide figura 2 - 2) 


\section{Comentário:}

A escrita da carta permite que os alunos iniciem a produção de um texto de autoria, porém, devido à estrutura fixa desse gênero, a proposta se assemelha a um decalque.

As formas de se iniciar e de se terminar uma carta já estão colocadas e há assuntos sugeridos, permitindo que os alunos já tenham em mente vários elementos antes de procederem à escrita. Até a sugestão de qual palavra pode ser usada na saudação da carta, após a identificação do remetente é uma forma de ajudar os alunos a definirem o que será escrito.

Ao colocar a palavra "na boca do outro", acaba-se incentivando a própria autoria, pois ao propor que se baseiem em uma forma de escrever, repetindo sua estrutura e apoiando-se em assuntos já indicados, é possível mostrar como se faz, permitindo que seja do seu jeito, reinterpretando-o à sua maneira. 


\section{Figura 2 - 2}

2. Quando crianças, todos nós imaginamos ser um super-herói ou uma super-heroína, com poderes especiais. Se isso fosse possível, que tipo de super-herói você gostaria de ser? Que poderes especiais teria? Por quê?

3. Se você fosse um super-herói:

a) O que faria primeiro para você mesmo ou para sua familia?

b) $\mathrm{O}$ que você mudaria no mundo em que vivemos?

4. O texto "A espada" lembra outra história, muito conhecida, que também gira em torno de uma espada mágica e seus poderes. Qual é essa história? Quem é o herói? Se você a conhece, conte para seus colegas como ela é.

\section{* Prodvção de texto}

\section{@ A CARTA PESSOAL \\ Leia esta carta pessoal:}

Maringás 15 de jultho de 2006.

Querido vô Artur

Munuiüito obrigado! Brigado! Brigado! Que presentaço! A molecada babou...

Vou contar: Pra comemorar mew aniversário de 8 anos, mãe fez uns cachorros-quentes,

encomendou aquele bolo gostoso da dona Antônia (o melhor bolo de Maringá'), etc., e deixou eu convidar meus amigos pra festa.

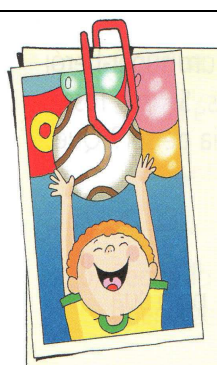

A turma chegou lá pelas quatro da tarde. Ganhei vários presentes. Lembra da Marcinha, a filha de sen Argemiro? Ganhei dela una camisa do men time que é dez! Depois, brincamos muito, nos empanturramos de sandubas, bebemos um montão de refric então mãe chamou pra cortar o bolo. Já tawa na hora (acho que mãe num agüentava mais aquela molecada suada correndo pra todo lado). Aí, ficou aquele "bolo" de gente em volta do bolo (de aniversário). Cantaram "Parabéns pra você", cantaram aquelas baboseiras "Com quem será...", recitaramo "Pique", apaguei as velas... e ai mãe disse que tinha uma surpresa para mim. Todo mundo ficou curioso. Eu, então... nem se fala. Aí, ela me entregou una caixa do correio e disse: "Ten avô te mandow". Vô, juro, meu coração disparou. Sei lá, en esperawa uma camiseta on umas meias... mas uma BOLA... De couro... e ainda a da SELEÇÃO!!!! Demais! Demais! Todo mundo queria ver e a bola passou de mão em mão. Quem quer bolo?, mãe perguntava. Bolo? Que bolo? Eu e a molecada já estáumomos lá fora discutindo as posiçöes, formando os times, armando o jogo, organizando a torcida. E ai, vô, minha festa de aniversário finalmente começou...

Vô, você é o maior vô do mundo! Eu tô morrendo de saudades! Quando é que o senhor e a vovó vão poder visitar a gente? Não vejo a hora de te dar um abraço bem apertado!

Beijo do sew neto,

Julinho

1. O texto lido é uma carta pessoal. Quando costumamos usar esse tipo de texto? Marque com um X:

$\square$ Quando queremos contar uma história engraçada.

$\square$ Quando queremos ensinar alguém a jogar determinado jogo.

\ Quando queremos comunicar um determinado assunto a amigos ou familiares, que geralmente estão distantes de nós. 
2. Quem envia a carta é chamado de remetente, e a pessoa para quem enviamos a carta é chamada de destinatário. Na carta em estudo:
a) Quem é o remetente?

b) Quem é o destinatário

3. Localize no texto lido e escreva:
a) local e data: Maringa, 15 de julho de 2006
b) o nome do destinatário, acompanhado de uma palavra carinhosa: Querido vô Artur
c) a assinatura do remetente, sem o sobrenome: Julinho

4. Além de local e data, nome do destinatário e assinatura do remetente, uma carta contém também assunto e despedida.

a) Na carta de Julinho, o assunto começa em "Muuuiiiito obrigado! Brigado! Brigado!". Onde ele termina? Năo vejo a hor de te dar um abraco bem apertadol

b) Que palavras Julinho usa para se despedir do avô? Beijo do seu neto

Por ter escrito uma carta pessoal, Julinho usou algumas palavras e expressões que empregamos no dia-a-dia, em conversas informais, mais íntimas, com nossos familiares e amigos, como, por exemplo, pra, brigado, demais, vô, então, aí, etc. Esse tipo de linguagem usada por Julinho chama-se linguagem informal.

5. Quando falamos, é comum reduzirmos certas palavras ou expressões. Por exemplo, a palavra pra é uma forma simplificada de para.

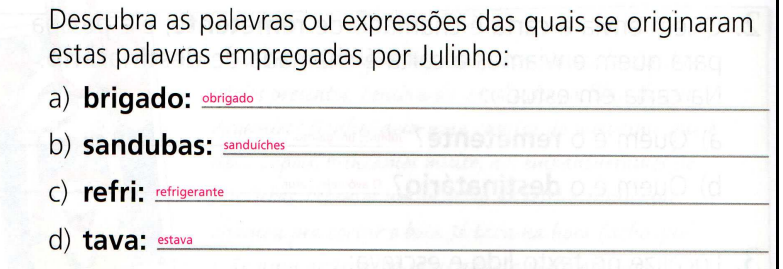

A carta é um tipo de correspondência que é enviada por correio, em um envelope. Observe, abaixo, como preencher um envelope:

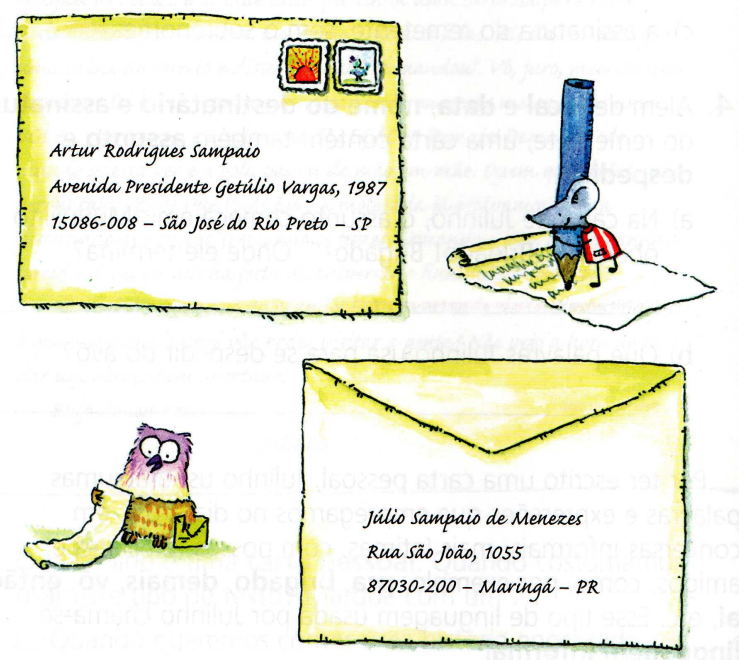

6. Agora, responda:

a) O que devemos escrever na frente do envelope?

onome e o endereso completos do destinatário 
b) 0 que devemos escrever no verso do envelope?

Onome e o endereso completo do remetente.

7. Ao lado do nome da cidade em que moram o remetente e o destinatário, há um número. Esse número é o código de endereçamento postal, nome que se abrevia por CEP. Você sabe qual é o CEP da rua onde mora?

Escreva-O. Professor: Para promover a interdisciplinaridade com Historia, Geografia e Ciências, sugerimos

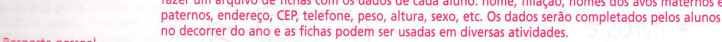

8. Agora, reúna-se em grupo e, seguindo a orientação do professor, escreva no quadro abaixo como é uma carta pessoal, isto é, quais são as características desse tipo de texto. A primeira característica já está no quadro.

\section{A carta pessoal}

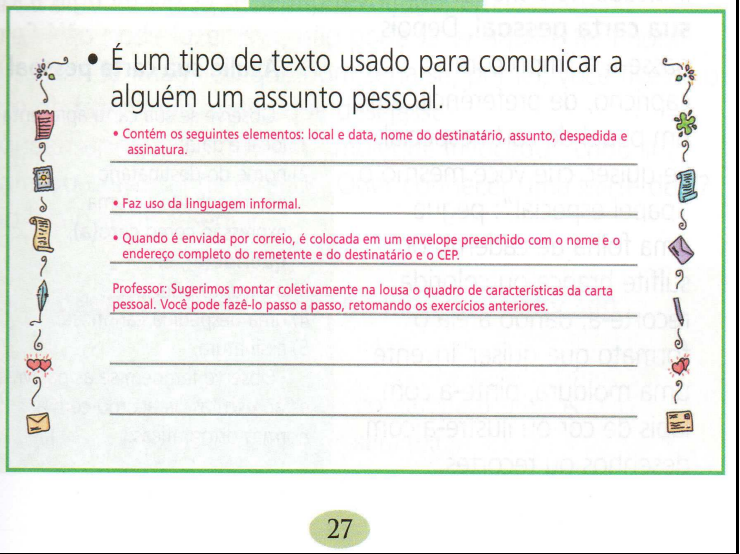

\section{@ AGORA É A SUA VEZ}

Que tal escrever uma carta para alguém e depois receber a resposta?

Siga as instruções:

a) Peça a seu professor o nome e o endereço completo de seu correspondente ou escolha um

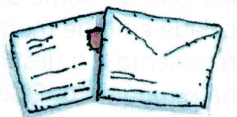
amigo de outra série com quem possa se corresponder.

b) Escolha um dos assuntos sugeridos abaixo ou pense em outro de sua preferência e escreva uma carta pessoal, comentando o assunto e convidando seu destinatário a dar uma resposta. Assuntos sugeridos:

- livros e revistas

- coleções

- animais de estimação

- programas prediletos na TV

- futebol e campeonatos

- heróis de TV e de revistas em quadrinhos

c) Leia sua carta, observando se ela contém o que está indicado no boxe Avalie sua carta pessoal. Depois passe-a a limpo com capricho, de preferência em um papel de carta especial. Se quiser, crie você mesmo o "papel especial": pegue uma folha de caderno ou sulfite branca ou colorida, recorte-a, dando a ela o formato que quiser. Invente uma moldura, pinte-a com lápis de cor ou ilustre-a com desenhos ou recortes.

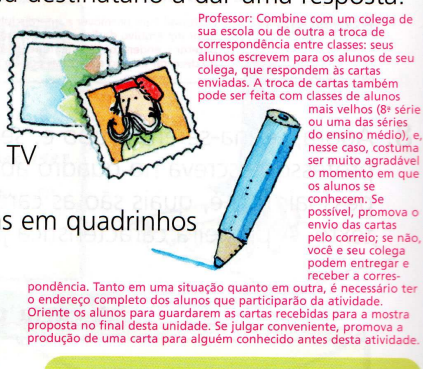

Avalie sua carta pessoal

Observe se sua carta apresenta: 1) local e data;

2) nome do destinatário

acompanhado de uma expressão como caro(a) querido(a), etc.;

3) o assunto principal;

4) uma despedida carinhosa; 5) assinatura.

Observe também se as palavras estão escritas de acordo com as normas ortográficas. 
d) Preencha o envelope com o nome e o endereço completo do destinatário e do remetente. Cole o selo. Depois, coloque a carta no correio, de acordo com as orientações de seu professor, e aguarde a resposta.

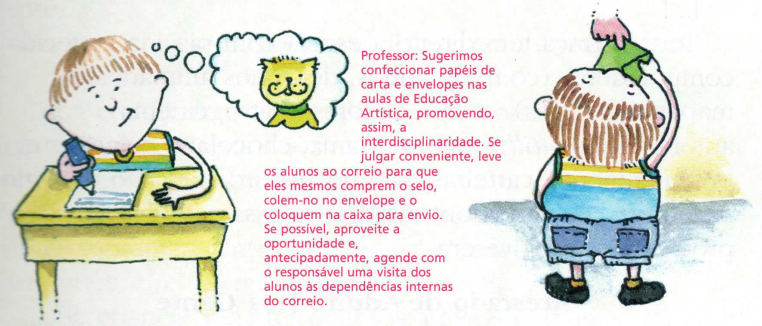

e) Se gostar da experiência, continue se correspondendo com seu colega.

\section{(1) Texto puxa texto}

Você alguma vez já se sentiu revoltado, em casa ou na escola? Não pode fazer isso, não pode fazer aquilo, tem hora para tudo... Já imaginou que bom seria se, por lei, você tivesse o direito de fazer tudo aquilo que desejasse?

Foi pensando nisso que um "moleque invocado" criou sua declaração universal de direitos. Quer conhecer uma parte dela? Então leia o texto a seguir:

\section{Declaração universal do moleque invocado}

[...]

Toda criança tem direito de comer pelo menos oito brigadeiros bem molinhos por semana. 


\begin{tabular}{|l|l|}
\hline Autor(es) & $\begin{array}{l}\text { SIMONCELLO, Vera Lucia, } \\
\text { ORCHIS, Amália e CHU, Angelina V. de Andrade. }\end{array}$ \\
\hline Nome da coleção & Registrando descobertas: língua portuguesa \\
\hline Editora & FTD \\
\hline Gênero textual & Conto maravilhoso \\
\hline Páginas analisadas & 09 a 27 \\
\hline
\end{tabular}

\section{Sequiência para análise textual:}

A sequência encontra-se na $1^{a}$ unidade do livro em que o tema são as diferenças. $O$ primeiro texto apresentado é o conto do Patinho feio, recontado pelas autoras do livro didático, a partir do original de Hans Christian Andersen.

As questões enfocam o entendimento do texto para que os alunos compreendam a sequência de fatos e suscita também inferências sobre os valores implícitos na história, como, por exemplo, o respeito pelo outro que é diferente. Há, inclusive, o estabelecimento de relações entre a história e a vida pessoal dos alunos, com o objetivo que discutam em sala outras situações de desrespeito que vivenciaram.

\section{Seqüiência para produção textual:}

A proposta de produção de texto prevê a reprodução/paráfrase de um conto clássico escolhido pela turma. Em um primeiro momento é solicitado que os alunos listem títulos de contos clássicos que conhecem, para depois fazer uma eleição na sala do conto preferido pela turma. A seguir, devem recontá-lo oralmente, com a ajuda do professor, que irá anotar as idéias principais na lousa.

A última etapa prevê a reprodução do conto individualmente.

(Vide figura 2 - 3) 


\section{Comentário:}

A reprodução/paráfrase de um conto clássico permite que os alunos acionem sua autoria, porém, com monitoramento. Escrevendo a partir de um modelo, poderão se concentrar mais na forma como irão escrever do que com o conteúdo, que já estará fixado.

Essa atividade tem como objetivo exercitar a escrita, retomando a estrutura da narrativa, gênero muito presente nos anos iniciais. Por esse motivo é esperado que os alunos tenham um repertório de contos e consigam lembrar-se da sua seqüência na hora da escrita. O apoio do reconto oral e as intervenções do professor na lousa irão garantir a recuperação dos fatos principais que não poderão faltar na história. Dessa forma, caberá aos alunos organizar a história, ressignificando-a à sua maneira.

A reprodução/paráfrase é uma forma de exercitar a autoria, pois não se trata de uma simples cópia. O apoio em modelos permite que os alunos possam escolher as melhores palavras para usar, atentando, inclusive a aspectos lingüísticos, como a ortografia e a pontuação, por exemplo. Ao basear-se nas idéias de outrem, estarão sendo monitorados e tendo mais ferramentas para escrever seu próprio texto. 
Figura 2 - 3
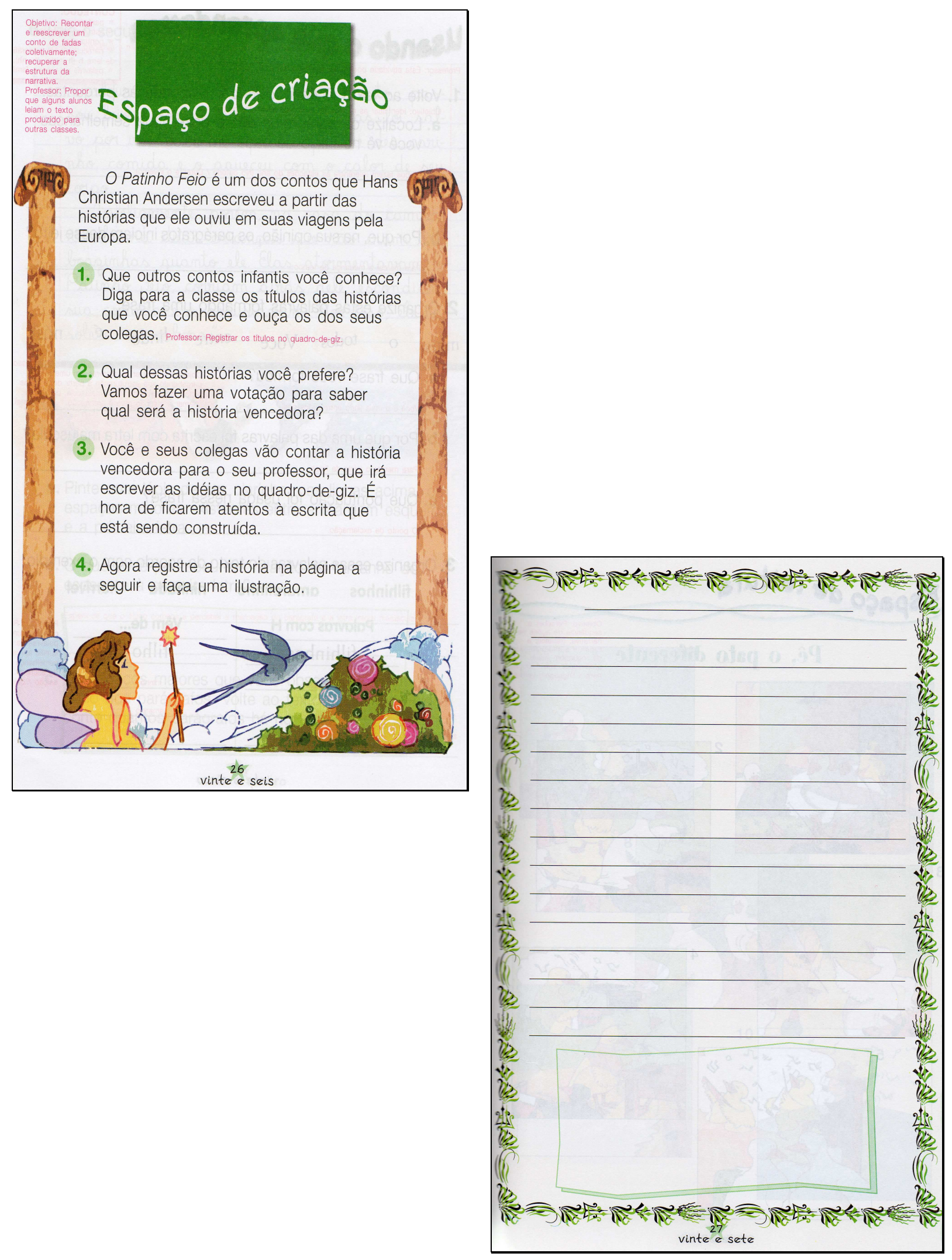


\begin{tabular}{|l|l|}
\hline Autor(es) & $\begin{array}{l}\text { PANACHÃO, Débora, CARVALHO, Carmen Silvia Cintra } \\
\text { Torres, KUTNIKAS, Sarina Bacellar, SALMASO, Silvia } \\
\text { Maria de Almeida e BARALDI, Maria da Graça Barreto. }\end{array}$ \\
\hline Nome da coleção & Construindo a escrita \\
\hline Editora & Ática \\
\hline Gênero textual & Autobiografia \\
\hline Páginas analisadas & 76 a 84 \\
\hline
\end{tabular}

\section{Seqüência para análise textual:}

O texto apresentado como modelo para análise e produção é o $7^{\circ}$ entre os dez presentes no livro. Trata-se de uma autobiografia, em que Anna Pavlova conta como se tornou uma bailarina. Foi retirado do livro Anna Pavlova: como me tornei uma bailarina, com tradução de Clara Lacerda e publicado pela Cosac\&Naif, em 2001.

A sequiência proposta traz questões de entendimento sobre o texto e seu vocabulário. Sobre a estrutura do gênero, possibilita comparações entre autobiografias e biografias, chamando a atenção para o uso da escrita em $1^{a}$ pessoa. Há também reflexões sobre o uso de adjetivos e de advérbios para conferir maior emoção aos textos.

\section{Seqüiência para produção textual:}

A proposta prevê a produção de uma autobiografia, destacando a importância de se escolher um trecho bem marcante da própria vida para escrever e depois contar aos colegas.

Há orientações para acrescentarem trechos com descrições e detalhes, usando adjetivos e advérbios para descrever os sentimentos, assim como no texto de Anna Pavlova. Os recursos analisados como, por exemplo, a presença de descrições dos fatos e a escolha dos acontecimentos mais importantes da própria vida, sentimentos e pensamentos poderão dar pistas aos alunos para decidir o que escrever quando forem produzir a autobiografia.

(Vide figura 2 - 4) 


\section{Comentário:}

Durante as atividades, o foco do trabalho é que os alunos percebam a importância de se escolher como se conta algo para transmitir mais emoção.

Ao destacar-se que há sempre um jeito melhor de se descrever um fato, acrescentando detalhes e os próprios sentimentos, por exemplo, será oferecido aos alunos um modelo de como escrever seu texto.

Ter acesso a diferentes modelos é uma forma de instrumentalizar o aluno para escrever o texto do seu jeito, baseando-se nas idéias de outrem. $\mathrm{O}$ trabalho com os gêneros textuais permite que a partir de uma estrutura fixa, cada um possa criar o seu próprio texto, desde que seja feita uma reflexão sobre a sua estrutura e sobre a intenção comunicativa.

Um outro aspecto a ser considerado é que os alunos escreverão sobre a própria vida, destacando um acontecimento importante. Portanto, o que irão escrever já estará definido e poderão concentrar-se mais na forma de registrar suas idéias no papel. 


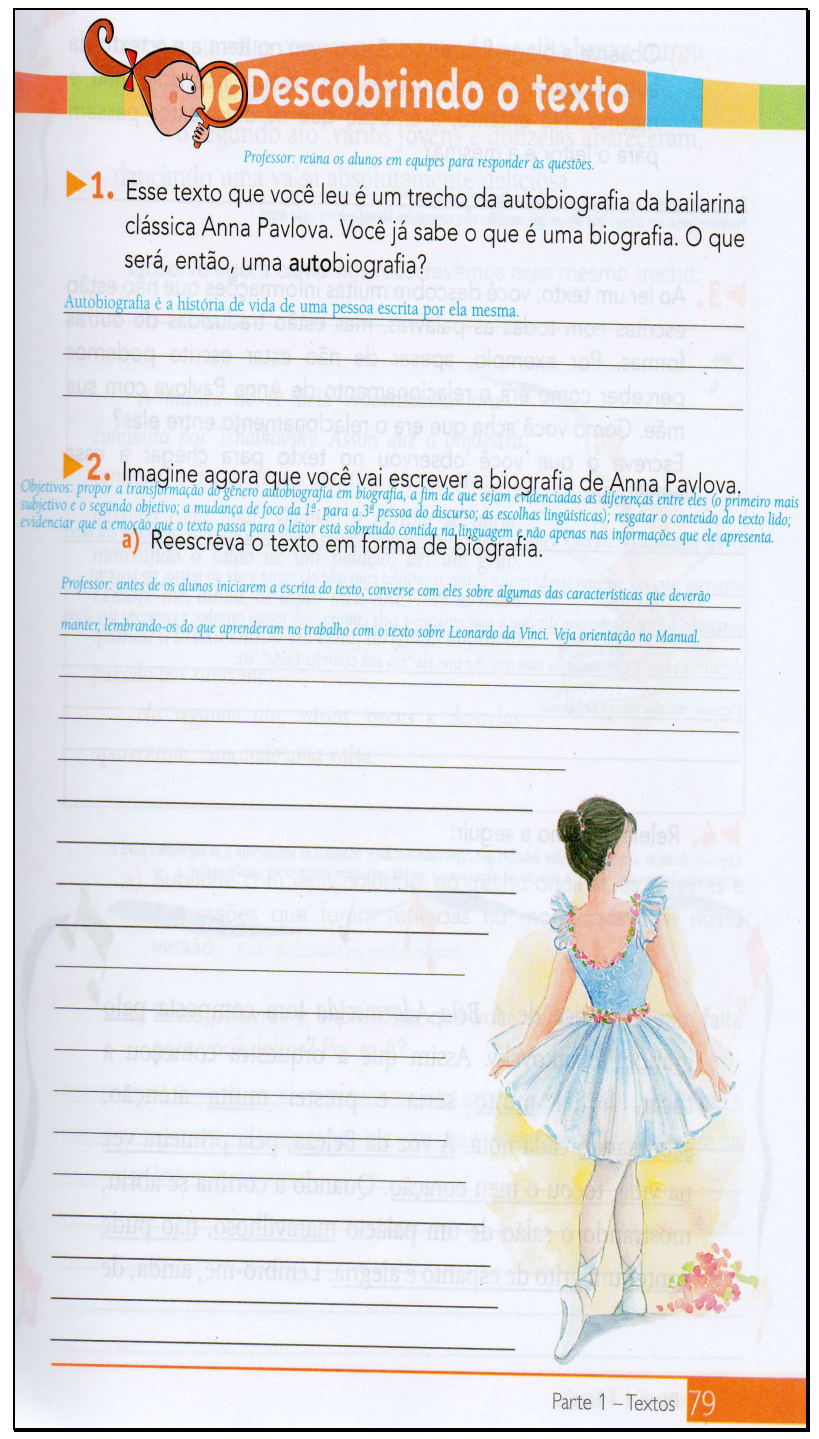

7. Você já descobriu várias características das biografias e das autobiografias. Compare os dois gêneros de texto e marque um $X$ nas características da biografia (letra B) com lápis vermelho e com um lápis verde, as características da autobiografia (letra A).

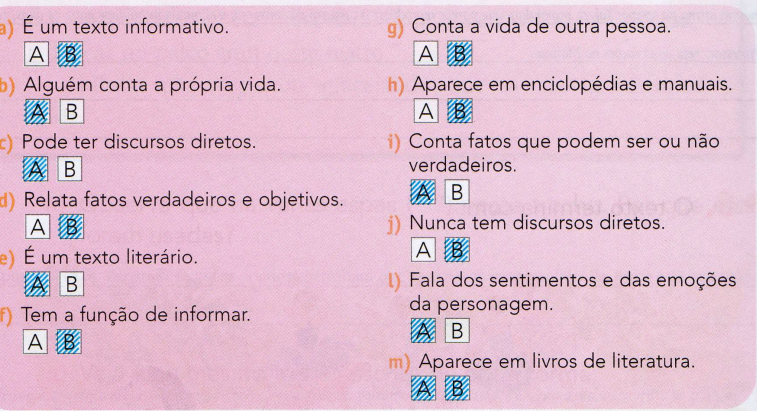

Agora que você fez novas descobertas é a hora do registro! Escreva em seu Diário de Descobertas tudo o que você aprendeu ao fazer esse trabalho. Professor, veja suguestäo de registro no Manual.

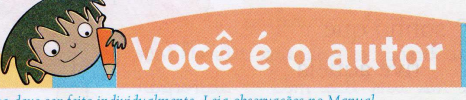

Professor: este trabaiho deve ser feito individual

Se você está pensando que nós vamos pedir que escreva sua autobiografia... acertou!

Só que não é preciso contar a vida toda, pode ser apenas um acontecimento que marcou você, por alguma razão, como nesse trecho da autobiografia de Anna Pavlova.

Antes de escrever, tente lembrar-se de um momento marcante de sua vida e faça seu roteiro para não se esquecer de nada. Procure também criar imagens e colocar detalhes que ajudem o leitor a imaginar como tudo aconteceu, como as coisas eram nessa época e o que você sentia.

Depois, faça um livro com folhas de papel sulfite dobradas, escreva seu texto e não se esqueça de ilustrá-lo!

Gostou de seu livro? Que tal escrever uma dedicatória e dá-lo de presente a alguém?

84 Parte 1 - Textos 


\begin{tabular}{|l|l|}
\hline Autor & SOARES, Magda Becker \\
\hline Nome da coleção & Português: Uma proposta para o letramento \\
\hline Editora & Moderna \\
\hline Gênero textual & Entrevista \\
\hline Páginas analisadas & 116 a 123 \\
\hline
\end{tabular}

\section{Seqüência para análise textual:}

A sequência analisada faz parte da unidade 3 do livro, que traz o tema medo. São apresentados vários gêneros com essa temática e o escolhido para análise é a entrevista. $\mathrm{O}$ modelo apresentado traz diferentes respostas dadas por pessoas reais, de diferentes gêneros, idades e profissões para duas perguntas: Medo de quê? E como enfrentá-lo? Foi retirado do Livro dos Medos, organizado por Heloisa Prieto e publicado pela Companhia das Letrinhas, em 1998, p. 37 a 41.

A análise prevê a comparação das respostas, a observação da estrutura desse gênero, a pontuação e diagramação utilizada para reproduzir as falas dos entrevistados.

\section{Seqüîncia para produção textual:}

A proposta prevê a escrita de um texto como o analisado, ou seja, os alunos deverão entrevistar diferentes pessoas, homens e mulheres, de diferentes idades sobre o que os faz ter medo e como fazem para afastá-lo. São dadas, inclusive, orientações sobre a forma de registrar as respostas e de identificar o entrevistado, além da melhor forma de organizar esse material, sugerindo a produção de um manual para ser lido pela turma e pelos familiares.

(Vide figura 2 - 5) 


\section{Comentário:}

A proposta da transcrição da entrevista reúne vários aspectos interessantes sobre a escrita de textos. Primeiro porque o modelo apresentado é a base para o trabalho, pois a proposta prevê a escrita de um texto com o mesmo tema do texto da autora analisada. Mas, a partir do momento em que o aluno irá registrar as respostas dos seus entrevistados, o texto não será mais o mesmo, pois um outro texto irá surgir.

$\mathrm{Na}$ verdade, o que se pede na proposta é que os alunos produzam seu texto utilizando o mesmo tema e a estrutura característica das entrevistas. Mas fica evidente que cada aluno produzirá um texto diferente, organizando a transcrição da entrevista a partir de diferentes respostas.

A estrutura fixa da entrevista permite que cada um possa escrever seu texto a partir de um modelo pré-determinado, cuja sequiência prevê a escrita de uma introdução, de perguntas e das respectivas respostas. O modelo e a estrutura são apresentados e são fundamentais para garantir a organização na compilação das respostas e a autoria se manifesta na hora de organizar as informações coletadas, que será sempre única. 
Figura 2 - 5

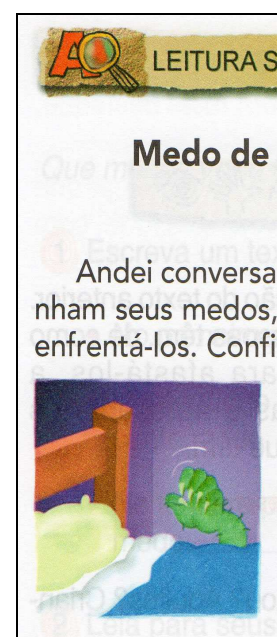

\section{().}

\section{ê? E como enfrentá-lo?}

\section{Silvinha Meirelles}

conversando com várias pessoas. Todas elas timedos, e algumas sabiam exatamente como s. Confira:

MEDO DE ESCURO "Eu tenho medo quando apago a luz, parece que alguém vem me pegar. Ou quando eu ponho o meu pé entre a cama e a parede, fico com medo de que saia uma mão verde acinzentada e pegue o meu pé."

ANTÍDOTO "Quando eu era pequena vi uns slides de patinhos. Então, até hoje, quando penso numa coisa ruim, mudo de assunto na minha cabeça como se estivesse trocando de slide."

Nina Albuquerque, 9 anos

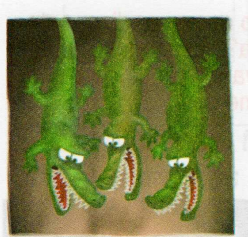

MEDO DIFERENTE "Penso numa caverna escura com um monte de jacaré pendurado de boca aberta para comer a gente."

ANTíDOTO Não sabe.

Ivan Limonge, 4 anos

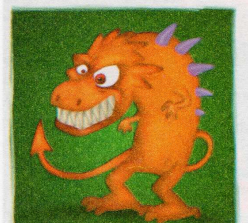

MEDO DE FICAR SOZINHA "Quando eu era pequena eu tinha medo de ficar sozinha porque eu achava que um monstro vinha me pegar."

ANTÍDOTO "Grudar no meu cachorro." Júlia Zanolli, 12 anos

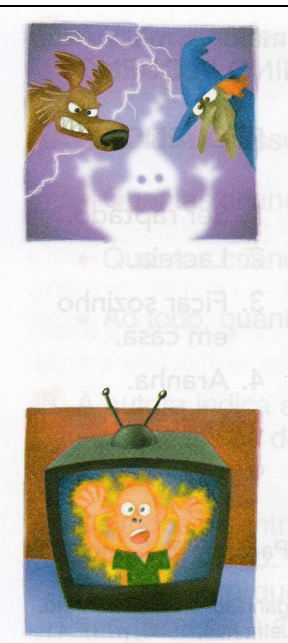

MEDO DE RAIO, DE FANTASMA, DE BRUXA E LOBO "Tenho medo de raio e de um fantasma me engolir. Também não gosto de história com bruxa e lobo, porque fico imaginando que eles vão sair da história para me buscar."

ANTÍDOTO "Eu me deito e me cubro."

Marcelo Nelzow, 6 anos

MEDO DE TERROR "Eu fico com medo quando assisto um filme e tem partes que assustam, como num filme que eu vi que tinha um cara pegando fogo."

ANTÍDOTO "Fecho os olhos."

Priscila Nemeth, 8 anos

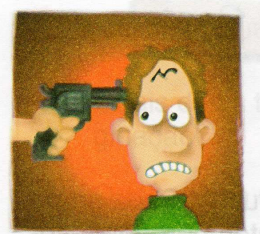

MEDO DE ASSALTO "Deve ser muito ruim ser assaltado com um revólver encostado na cabeça."

ANTÍDOTO "Ficar sempre atento. Se acontecer, não reagir é a melhor solução."

Ildo da Silva, 32 anos, guarda-noturno

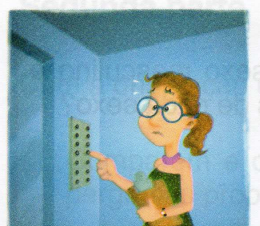

MEDO DE ELEVADOR "Não gosto de lugar alto, nunca olho para baixo. Mas o pior é elevador, se estiver cheio, subo pelas escadas."

ANTÍDOTO "Fingir que não estou dentro de um elevador."

Ana Maria Escobar, 39 anos, pediatra 
Aqui vai uma lista de alguns dos maiores medos de um MENINO GRANDE e de um MENINO PEQUENO:

\section{GRANDE}

1. Na hora do futebol, errar o chute. 1. Ser raptado.

2. Fazer a prova sem ter estudado.

3. Estar apaixonado e encontrar a menina.

2. Lacraia.

3. Ficar sozinho em casa.

4. Cortar o cabelo e ficar horroroso.

5. Soltar um pum e todos rirem.

6. Ler o boletim da escola.

4. Aranha.

5. Ladrão.

6. Cobra.

Pedro S., 13 anos

Paulinho P., 5 anos

O Livro dos medos. Organização Heloisa Prieto. São Paulo: Companhia das Letrinhas, 1998, p. 37-41.

\section{INTERPRETAÇÃO ORAL}

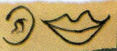

\section{Primeira parte}

O professor vai organizar a turma em grupos. Cada grupo vai encontrar respostas para as seguintes perguntas sobre o texto. Anotem as respostas, para discuti-las com a turma depois.

(1) A autora entrevistou pessoas do sexo masculino e pessoas do sexo feminino. Quantas de cada sexo?

\section{LINGUA ORAL-LINGUA ESCRITA S}

Como é que podemos indicar para quem lê que o que está escrito são as palavras que alguém falou?

Observe que os antídotos estão escritos entre aspas, só o antídoto de Ivan - o do MEDO DIFERENTE - não está entre aspas. Discuta com o professor e seus colegas:

- Para que servem as aspas, na apresentação dos antídotos?

- Por que a autora não usou as aspas quando escreveu o antídoto de Ivan?

\section{PRODUÇÃO DE TEXTO}

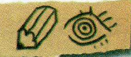

Você vai fazer como a autora: entrevistar pessoas e conseguir depoimentos sobre os medos que elas têm e o que fazem para afastá-los (os antídotos que usam).

Depois, a turma vai fazer um manual dos medos que as pessoas têm e antídotos que usam.

(4) Entreviste algumas pessoas, homens e mulheres, de diferentes idades, perguntando a cada uma:

Tem medos? De quê?

O que faz para afastar o medo?

Escreva as respostas dos entrevistados e os antídotos para seus medos, imitando a forma que a autora usa no texto:

- Escreva um título para a fala da pessoa, com letras maiúsculas (MEDO DE...). 


\section{UNIDADE 3 MEDO? TODO MUNDO TEM!!}

- Escreva a fala da pessoa entre aspas.

- Escreva o ANTÍDOTO também entre aspas, se for a fala da pessoa.

- Registre, abaixo de cada depoimento, o nome do entrevistado, a idade e, se a pessoa tiver uma profissão, qual é ela.

Use uma folha de papel para cada pessoa. A turma deve escolher que tipo de folha deve ser usado, para que vocês possam depois montar o manual, juntando folhas iguais.

(2) Reúna-se em grupo com alguns colegas.

Verifiquem, de acordo com as pessoas que cada um pôde entrevistar:

- Quantas pessoas foram entrevistadas pelo grupo.

- Quantos homens e quantas mulheres.

- De que idades eram as pessoas, separando-as em: crianças pequenas, crianças maiores, jovens, adultos.

Leiam, uns para os outros, as respostas obtidas.

3 Sob a orientação do professor, verifiquem: quantas pessoas ao todo foram entrevistadas pela turma? Quantos homens e quantas mulheres; de que idades?

Escrevam em conjunto, sob a orientação do professor, uma introdução para o manual, explicando que ele contém depoimentos de pessoas sobre os medos que têm e o que fazem para afastar esses medos (os antídotos), e informando quantas pessoas foram entrevistadas, sexo e idade delas. Esta será a primeira página do manual. 


\begin{tabular}{|l|l|}
\hline Autor(es) & $\begin{array}{l}\text { CARPANEDA, Isabella Pessoa de Melo e BRAGANÇA, } \\
\text { Angiolina Domanico }\end{array}$ \\
\hline Nome da coleção & Porta Aberta: língua portuguesa \\
\hline Editora & FTD \\
\hline Gênero textual & Convite \\
\hline Páginas analisadas & 134 a 136 \\
\hline
\end{tabular}

\section{Seqüência para análise textual:}

A proposta prevê uma análise oral de um convite, pois encontra-se em uma unidade que mescla vários gêneros para o estudo. Os alunos irão analisar um texto não-verbal, no caso uma obra de arte e depois irão recriar a obra analisada. Essa atividade dará origem a uma exposição, cujo convite os alunos terão que produzir. Para auxiliar essa produção, os alunos observarão um convite criado pelas autoras do livro didático e responderão a perguntas que remontam a estrutura desse gênero, como, por exemplo, a importância de se escrever a data, local e horário da exposição.

\section{Seqüiência para produção textual:}

Esta proposta de produção apresenta claramente uma função social (convidar a comunidade escolar para assistir à exposição) e destinatários reais (alunos, professores e familiares). Na própria comanda do exercício há o alerta sobre a importância do modelo nesta atividade: os autores do livro convidam os alunos a ler o convite apresentado, pois ele dará pistas para a escrita do próprio convite. Além disso, são oferecidas algumas perguntas para orientar a revisão desse texto.

(Vide figura 2 - 6) 


\section{Comentário:}

O convite é um gênero que apresenta uma estrutura fixa e, portanto, compreende uma série de informações que passam a ser essenciais nos momentos de produção escrita.

Ao submeter-se ao modelo, espera-se, na verdade, que os alunos baseiem-se na sua estrutura para produzir o seu próprio convite, que terá as informações referentes à sua própria exposição. Portanto, não se trata de uma simples cópia de um modelo, mas sim de um monitoramento de como escrever.

Os alunos irão organizar as informações ao seu modo, respeitando as características do gênero, de acordo com o modelo apresentado.

Essa tarefa de escrita permite que acionem seus conhecimentos a partir de um fazer orientado, de uma consulta a um modelo, garantindo a autoria ao escrever o conteúdo de acordo com suas informações. 
Figura 2 - 6

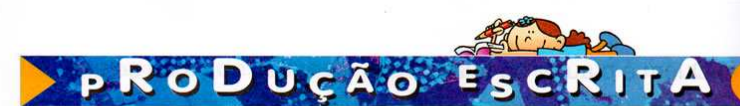

Criem convites para que alunos de outras turmas, professores e familiares visitem a exposição.

Com a ajuda do professor, definam:

\ onde e quando a exposição será realizada.

$\downarrow$ qual o horário em que poderá ser visitada.

४ quanto tempo os trabalhos ficarão expostos.

Leia o convite abaixo. Ele dará pistas para elaborar o seu.

\section{O N V I T E}

Convidamos alunos, professores e familiares para GRANDE EXPOSIÇÃO LITERÁRIA, a ser realizada no dia 21 de agosto, sábado, a ser realizad no auditório Monteiro Lobato. as 10 horas, no auditón com a sua presença.

Alunos da 2a série

Escreva o convite no rascunho e mostre-o para o seu colega ao lado. Ele irá verificar se o seu convite informa:

$\downarrow$ quem está sendo convidado.

$\checkmark$ o motivo do convite.

$\downarrow$ a data, a hora e o local da exposição.

$\downarrow$ quem está convidando.

Caso seja necessário, acrescente as informações sugeridas pelo seu colega.

Passe o convite a limpo e copie-o de acordo com a quantidade de seus convidados. Depois entregue-os.

$$
\text { (18) } 1363
$$




\section{$4^{\circ}$ ANO / $3^{\text {a }}$ SÉRIE}

\begin{tabular}{|l|l|}
\hline Autor(es) & $\begin{array}{l}\text { Obra coletiva concebida, desenvolvida e produzida pela } \\
\text { Editora Moderna }\end{array}$ \\
\hline Nome da coleção & Projeto Pitanguá \\
\hline Editora & Moderna \\
\hline Gênero textual & Poema \\
\hline Páginas analisadas & 169 a 171 \\
\hline
\end{tabular}

\section{Seqüiência para análise textual:}

Apresentação do gênero por meio dos textos Eu juro que vi e Sem futuro, de Sérgio Caparelli, retirados do livro Tigres no quintal, Ed. Kuarup.

Os textos encontram-se em uma unidade do livro cujo tema é a mentira e exploram-no em forma de brincadeira ou utilizando o nonsense.

As questões de compreensão do texto enfatizam essa idéia da mentira enquanto uma situação absurda, comparando os versos dos poemas apresentados que utilizam brincadeiras com as palavras por meio das rimas. Os alunos devem perceber que a escolha das palavras privilegia a rima entre elas, produzindo humor ao propor situações em que impera o nonsense, como a que aparece, por exemplo, nos seguintes versos do poema analisado:

"Eu vi um dromedário

fazendo tricô no armário."

\section{Seqüência para produção textual:}

A tarefa consiste na criação de versos que completem os versos presentes no livro e dados pelo autor. Caberá aos alunos continuar cada verso dizendo o que viram, de acordo com o estilo do poema analisado.

(Vide figura 3 - 1) 


\section{Comentário:}

A categoria de produção textual proposta é o decalque. Essa atividade consiste em propor uma escrita preenchendo lacunas a partir de um texto já conhecido. O modelo a ser seguido faz com que o "imitar" ajude a criar, pois ao repetir uma estrutura, os alunos ganham autonomia e segurança para decidir o que escrever em algumas partes do poema, no caso no momento em que completam o verso dado.

O poema é um gênero textual que exige muitas inferências por parte dos alunos para ser compreendido e, portanto, para ser escrito também. Nos anos iniciais o foco é o trabalho com a criação de rimas e o decalque de poemas bem escritos, focando a atenção dos alunos para alguns aspectos. Na proposta analisada, as crianças estarão exercendo sua autoria por meio da criação de outros pares de versos, porém a estrutura já estará definida: rima no final dos versos com situações engraçadas ou impossíveis. 
Figura 3 - 1

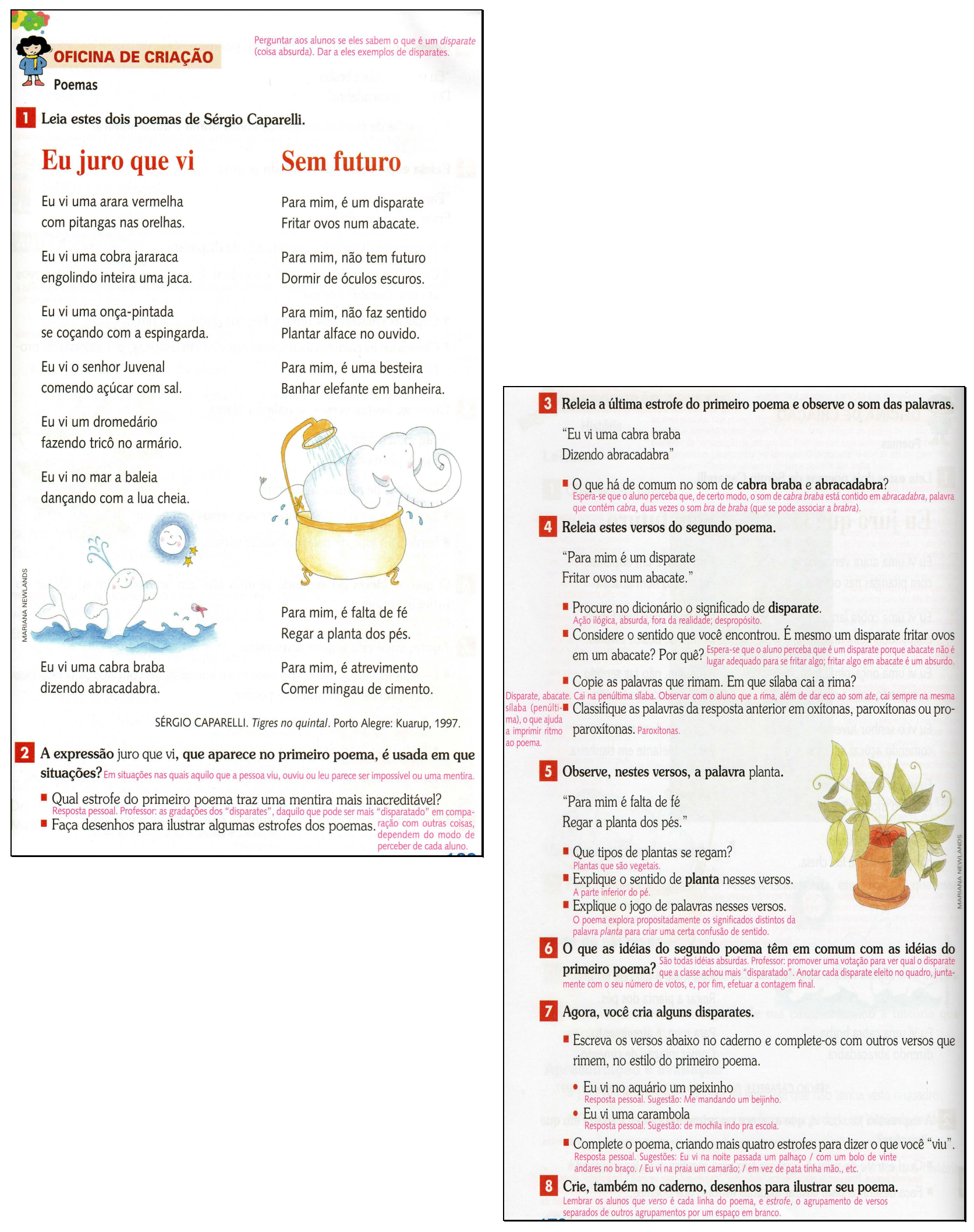




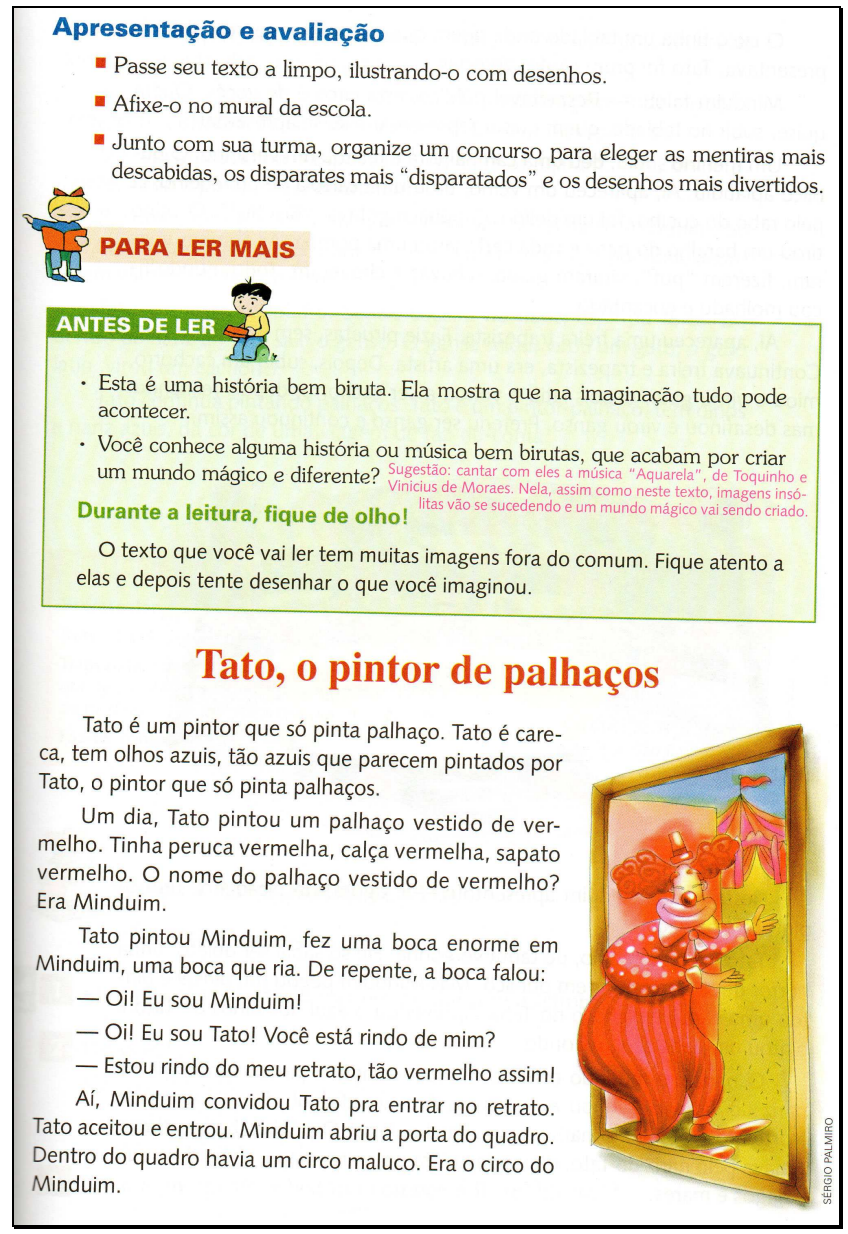




\begin{tabular}{|l|l|}
\hline Autor(es) & William R. Cereja e Thereza C. Magalhães \\
\hline Nome da coleção & Português: linguagens \\
\hline Editora & Atual \\
\hline Gênero textual & Notícia \\
\hline Páginas analisadas & 144 a 147 \\
\hline
\end{tabular}

\section{Sequiência para análise textual:}

A sequência faz parte de uma unidade cujo tema é a família. Porém a notícia analisada não refere-se diretamente ao assunto em questão: trata-se da análise de uma notícia sobre um fato curioso: queda de um meteorito em uma cidade da Bahia, Queda de meteorito assusta baianos, escrito por Biaggio Talento e publicado no Jornal O Estado de São Paulo de 08/03/2006.

As questões enfocam as características do texto jornalístico, os suportes onde é possível encontrá-lo e o principal fato que o diferencia dos contos: o compromisso com a verdade.

O enfoque maior é dado à estrutura do lide, parágrafo inicial da notícia, que traz o assunto principal do texto e as informações mais importantes.

\section{Seqüência para produção textual:}

A situação de produção prevê a escrita de uma notícia sobre um fato ocorrido na escola, bairro ou cidade do aluno para compor um jornal coletivo que será lido pela comunidade escolar.

Há uma proposta de revisão do próprio texto, com enfoque na escrita do primeiro parágrafo para verificar se ele responde às perguntas que fazem parte do lide: o que, quem, onde e porque.

Há também orientações sobre a linguagem utilizada, chamando a atenção para o uso de uma linguagem mais formal.

(Vide figura 3-2) 


\section{Comentário:}

A escrita da notícia também prevê uma estrutura fixa, no caso o parágrafo inicial, chamado de lide pelos jornalistas, e acaba por auxiliar os alunos na organização das idéias. $\mathrm{O}$ que escrever também já está posto, uma vez que deverão escrever sobre um fato real, conhecido pelos alunos. Esse dois fatores atuam de forma positiva no momento da criação do texto, pois são formas de orientar a escrita, ajudando os alunos a decidirem o que e como escrever.

A principal característica das notícias é a objetividade, informando os leitores sobre um fato. Daí a importância de seguirem a estrutura do lide: trata-se de organizar o que se diz a partir de respostas para cinco perguntas básicas sobre o fato: quem, fez o que, onde, quando e porque. Seguindo essa estrutura garante-se que as informações principais sobre o fato noticiado estejam presentes, garantindo o entendimento por parte do leitor e tornando o texto mais organizado.

Durante a análise do modelo apresentado, os alunos irão observar que essa estrutura inicial se repete e poderão utilizá-la para escrever seus textos. Ao seguir o modelo, não estarão copiando-o, mas observando sua estrutura para reproduzi-la no próprio texto. 


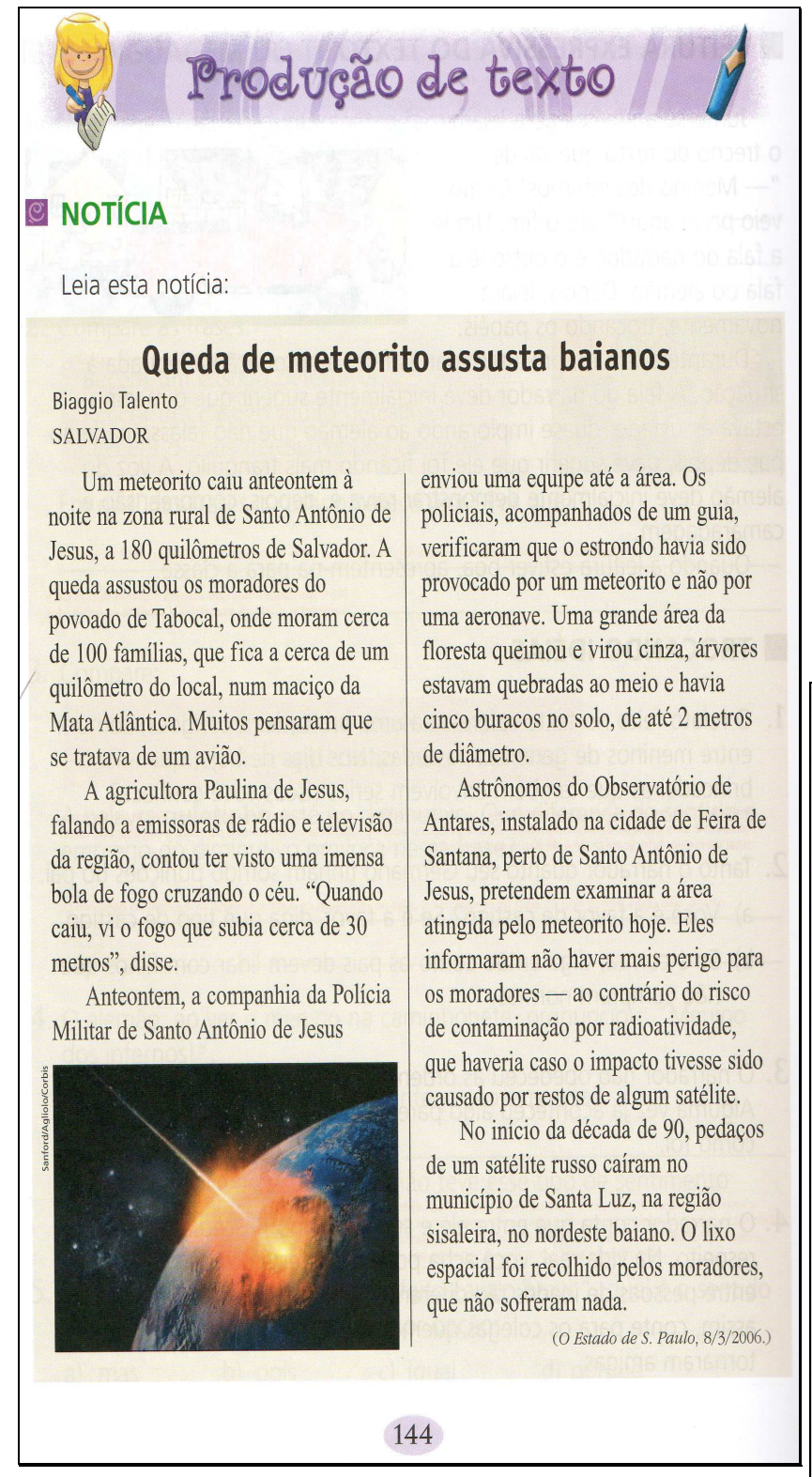

144

1. Uma notícia é um texto jornalístico que relata fatos reais que interessam ao público. As notícias são transmitidas só por jornais e revistas?

N30, elas podem ser transmitidas também por rádio, por televisiōo, pela Internet.

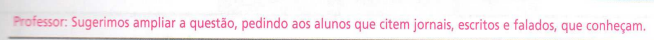

2. As fábulas, as lendas e os contos maravilhosos narram fatos imaginados. Uma notícia relata fatos imaginados ou fatos reais? Fatos reais.

Uma notícia geralmente apresenta duas partes. restante da notícia. informações. baianos".

A primeira parte é formada pelo primeiro parágrafo do texto e resume as informações mais importantes da notícia. Assim, o leitor fica curioso para saber mais e se sente motivado para ler 0

O primeiro parágrafo da notícia procura responder a algumas perguntas, como: Quem?, Fez o quê?, A quem? (ou $O$ que aconteceu a quem?), Onde?, Quando?, Como?, Por quê?, etc.

A segunda parte é constituída pelos demais parágrafos do texto. Ela amplia o primeiro parágrafo, acrescentando outras

3. Releia o primeiro parágrafo da notícia "Queda de meteorito assusta

a) Qual é o fato principal relatado?

O menor jornal

A jornalista Dolores Nunes Schwindt é a responsável pelo menor jornal do mundo. No dia 23, o microjornal Vossa Senhoria, da cidade de Divinópolis (MG), recebeu o certificado do Guinness Book, o livro de recordes, atestando que o seu jornal, com apenas 3,5 centimetros de altura e 2,5 centímetros de largura, é o menor do mundo. 0 jornal tem 16 páginas mensais, tiragem de 5 mil exemplares e aborda diversos assuntos da atualidade. (Zá, n? 38.)

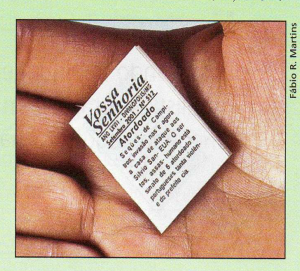
A queda de um meteorito na Bahia. 
b) Onde aconteceu o fato principal relatado?

Na zona rural de Santo Antônio de Jesus, a 180 quilömetros de Salvado

c) Quando aconteceu esse fato?

Anteontem à noite (6 de marco de 2006).

4. Na segunda parte da notícia são acrescentadas outras informações. Na notícia lida, quantos parágrafos desenvolvem o primeiro? Quatro parágrafos.

5. Toda notícia tem um título. Na notícia em estudo:

a) O título dá idéia do que a notícia trata?

\section{Vossa
Senhoria
Solnt.} enhoria

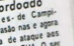
$\underline{\sin }$

b) Ele é curto, claro, direto e com verbo no presente? sim

6. Observe a linguagem empregada na notícia lida.

a) Ela contém gírias, palavras abreviadas ou palavras e expressões próprias da linguagem oral, cotidiana? Nằ.

b) Observando a linguagem da notícia lida, concluímos que os textos jornalísticos empregam a língua padrão? Ou que empregam uma variedade lingüística não padrão da língua?

Os textos jornalisticos empregam a lingua padrāo.

c) Há, na notícia lida, expressões como eu acho que, na minha opinião ou eu penso que?

Năo.

7. Agora reúna-se com seus colegas de grupo e, seguindo as orientações do professor, escreva no quadro abaixo as características da notícia. A primeira característica já está no quadro.

\section{A notícia}

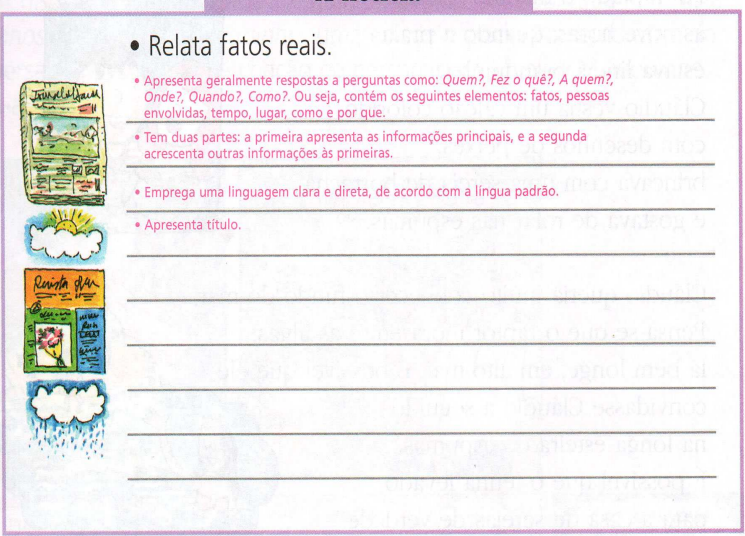

AgORA É A SUA VEZ

1. Pense em um fato ocorrido em sua escola, em seu bairro ou em sua cidade e escreva uma notícia relatando esse fato. Quando terminar seu texto, leia-o para os colegas. Depois, guarde a notícia para fazer parte do jornal que você produzirá com seus colegas no projeto da Oficina de Criação desta unidade. Esse jornal deverá ser lido por colegas de outras classes, professores e funcionários da escola, por seus amigos e familiares.

Avalie sua notícia

Quando terminar de escrever sua notícia, releia-a, observando:

1) se ela apresenta um título curto e direto, com verbo no presente;

2) se o primeiro parágrafo apresenta 0 fato principal, a(s) pessoa(s) envolvida(s), quando, onde, como por que o fato relatado aconteceu; 3) se os demais parágrafos

acrescentam outras informaç̃es à informação principal;

4) se a linguagem utilizada está de acordo com o público leitor e com a língua padrão. 


\begin{tabular}{|l|l|}
\hline Autor(es) & $\begin{array}{l}\text { SIMONCELLO, Vera Lucia, ORCHIS, Amália e } \\
\text { CHU, Angelina Verônica de Andrade. }\end{array}$ \\
\hline Nome da coleção & Registrando descobertas: língua portuguesa \\
\hline Editora & FTD \\
\hline Gênero textual & Carta \\
\hline Páginas analisadas & 26 a 31 \\
\hline
\end{tabular}

\section{Sequiência para análise textual:}

O gênero em estudo é a carta e faz parte da unidade 1 do livro, cujo tema são as mudanças de um lugar para outro. O texto analisado é uma carta, escrita por Regina Siguemoto para a Revista Alegria n $^{\circ} 95$ e publicada pela editora Abril, em 1990. É uma carta fictícia e trata-se de uma mensagem de um garoto ao seu avô. As questões giram em torno das características do gênero, principalmente da sua estrutura. Durante a análise, também é proposta a discussão da função de um texto como esse e o preenchimento do envelope.

\section{Seqüiência para produção textual:}

A proposta prevê a escrita de uma carta para um interlocutor real.

Há um pequeno roteiro para que os alunos possam se apoiar durante a escrita, com lembretes sobre a estrutura: presença de um destinatário e de um assunto.

Depois de escrever o texto, os alunos são convidados a revisá-lo e outras questões são apresentadas sobre a estrutura do gênero e sobre a linguagem mais adequada, de acordo com o interlocutor escolhido.

(Vide figura 3 - 3) 


\section{Comentário:}

A carta é um gênero textual que permite que o aluno exercite sua autoria com ajuda.

Ao explorar a estrutura deste texto, os alunos estarão refletindo sobre uma forma fixa de organizar o texto, portanto poderão debruçar-se mais sobre o que escrever, ou seja, sobre o seu conteúdo.

O modelo, neste caso, atuaria como um suporte para a escrita, dando as diretrizes sobre a organização das idéias e para a forma de escrever. Cabe ao aluno articular esses conhecimentos de acordo com o interlocutor escolhido e com o assunto definido.

O monitoramento da atividade garante a segurança para que o aluno possa se lançar ao texto e colocar suas idéias de forma organizada, sem perder sua originalidade e sua autoria. 


\section{Figura 3 - 3}

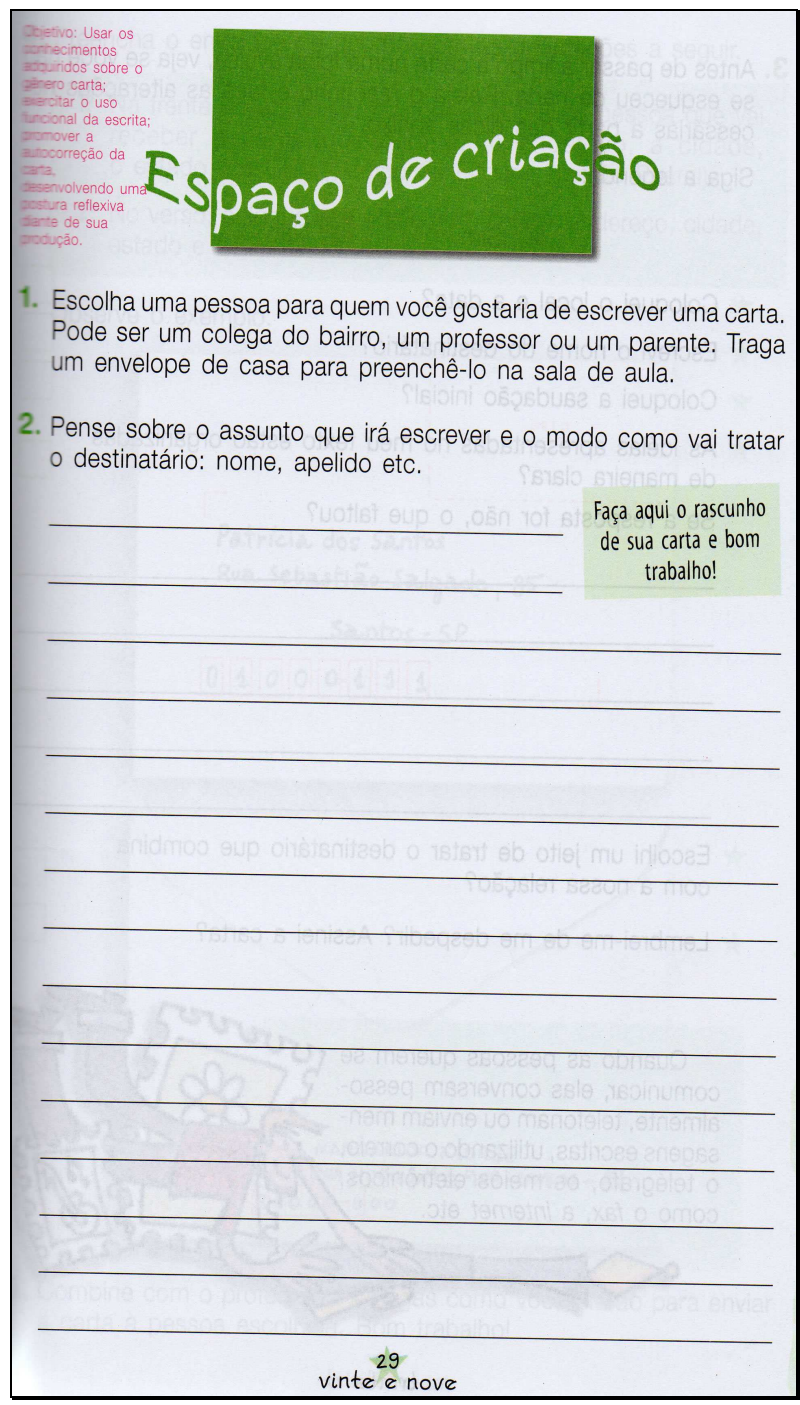

3. Antes de passar a limpo a carta numa folha avulsa, veja se você não se esqueceu de nada. Releia o rascunho e faça as alterações necessárias a partir das dicas abaixo.

Siga a legenda:

$$
\operatorname{Sim}
$$

\section{Coloquei o local e a data?}

Escrevi o nome do destinatário?

Coloquei a saudação inicial?

As idéias apresentadas no meu texto estão organizadas de maneira clara?

Se a resposta for não, o que faltou?

Escolhi um jeito de tratar o destinatário que combina com a nossa relação?

Lembrei-me de me despedir? Assinei a carta?

Quando as pessoas querem comunicar, elas conversam pessoalmente, telefonam ou enviam mensagens escritas, utilizando o correio, o telégrafo, os meios eletrônicos como o fax, a internet etc.

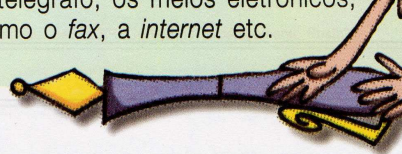




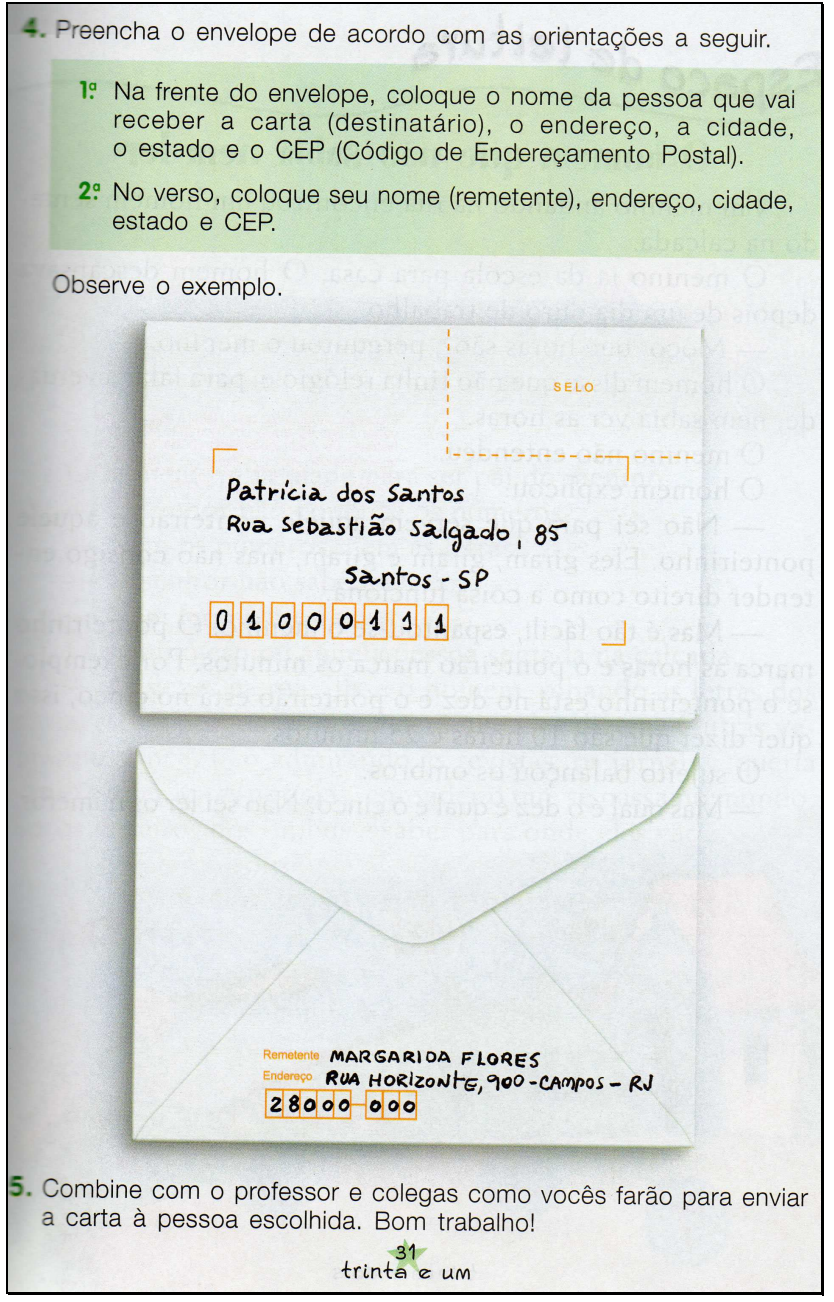




\begin{tabular}{|l|l|}
\hline Autor(es) & $\begin{array}{l}\text { PANACHÃO, Débora, CARVALHO, Carmen Silvia Cintra } \\
\text { Torres, KUTNIKAS, Sarina Bacellar, SALMASO, Silvia } \\
\text { Maria de Almeida e BARALDI, Maria da Graça Barreto. }\end{array}$ \\
\hline Nome da coleção & Construindo a escrita \\
\hline Editora & Ática \\
\hline Gênero textual & Poema \\
\hline Páginas analisadas & 10 a 15 \\
\hline
\end{tabular}

\section{Sequiência para análise textual:}

A seqüência proposta é o primeiro texto apresentado no livro para o trabalho de leitura e de produção textual, dentre os dez apresentados.

Trata-se de um poema concretista, Poeminhas cinéticos, escrito por Millôr Fernandes e retirado do livro Trinta anos de mim mesmo, publicado pela editora Nórdica, em 1972.

Nesse poema, o autor utiliza vários recursos gráficos para criar seus versos, conferindolhe humor e várias possibilidades de interpretação. Para ajudar no entendimento do texto, os alunos devem perceber que a forma como foram escritas as últimas palavras de cada verso pode conferir diferentes significados ao texto e que se esse recurso não tivesse sido utilizado, não seria possível compreender as intenções propostas pelo autor.

\section{Seqüência para produção textual:}

Em um primeiro momento, os alunos irão realizar um decalque do poema, criando outras formas de terminar os versos, a partir dos mesmos recursos utilizados pelo autor.

As orientações dos próprios autores do livro indicam que os alunos deverão criar formas diferentes de continuar cada verso, assim como o autor do texto fez, ou seja, usando efeitos especiais para grafar as palavras. Depois, a proposta é a criação de um outro poema, utilizando efeitos especiais.

(Vide figura 3 -4) 


\section{Comentário:}

Este é um interessante exemplo em que a cópia de um modelo e o exercício da autoria convivem de forma harmônica. Sem a presença de um modelo para análise os alunos teriam mais dificuldade para criar seus próprios versos, pois a falta de repertório desse gênero atuaria como um empecilho para a produção, uma vez que este gênero não é tão comum para os alunos e exige uma grande capacidade de inferência para ser compreendido por quem lê.

Porém, é nítida a percepção de como a cópia do recurso utilizado não influencia o trabalho de autoria do aluno, pois cada um irá completar o seu verso de um jeito diferente, conferindo a uma mesma palavra uma multiplicidade de sentidos ou utilizar um mesmo recurso em situações diferentes. Trata-se de colocar em prática o jogo de concretizar sentidos, de acordo com o recurso empregado pelo autor analisado, pois ao escrever uma palavra usando efeitos especiais diferentes para indicar de que forma a personagem saiu de um botequim ou qualquer outro assunto, os alunos produzirão textos diferentes, usando muitas vezes uma mesma palavra.

Vale ressaltar que os alunos são incentivados pelos próprios autores do livro didático a consultarem outros modelos de poemas com os mesmos recursos analisados para terem mais idéias de como escrever seu próprio texto. 
Figura 3 - 4
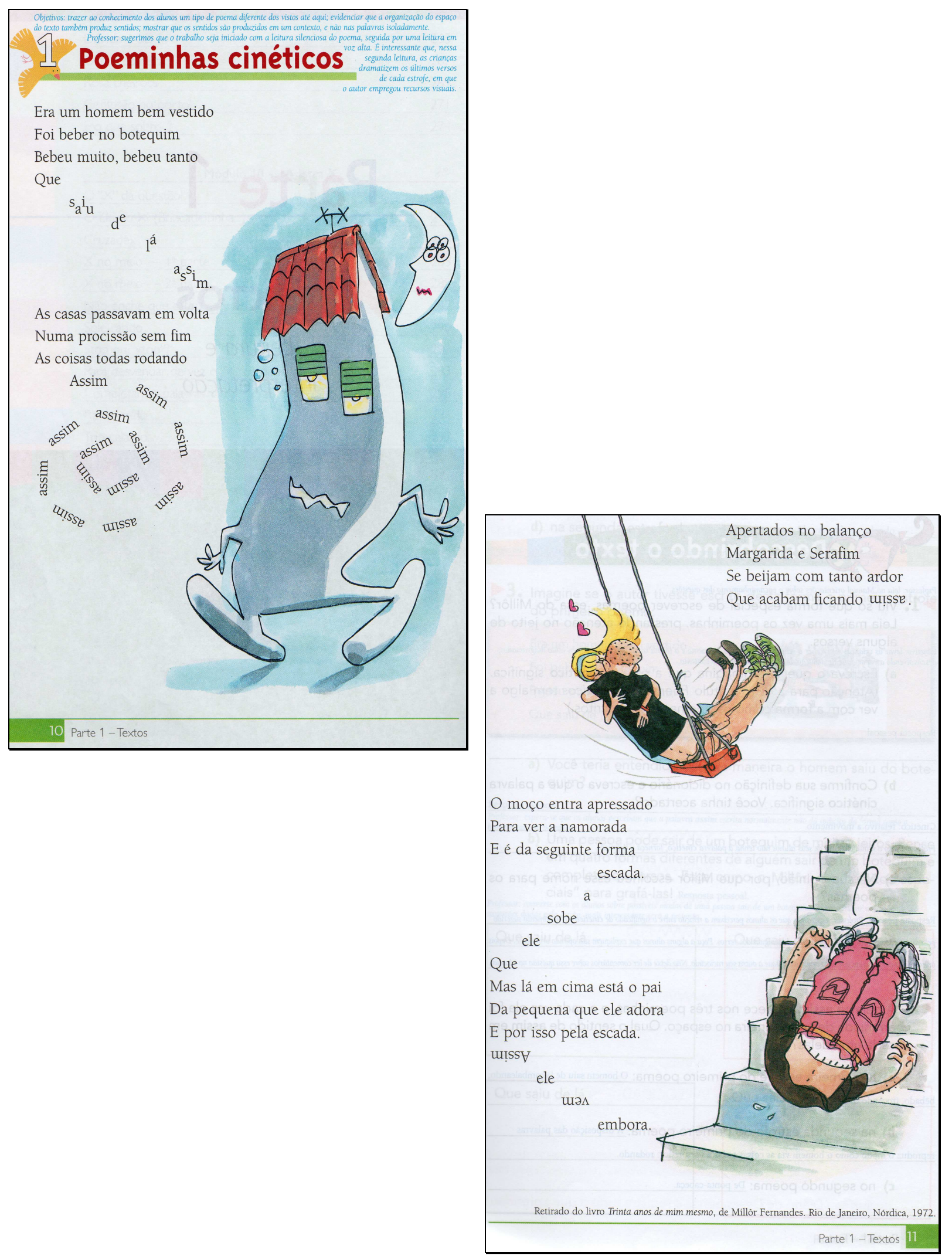
d) na segunda estrofe do terceiro poema: Ele vai embora rolando. Professor: explore tambem a forma como o ultimo verso da primeira estrofe do terceiro poema está diagramado

3. Imagine se o autor tivesse escrito desta forma a primeira estrofe do primeiro poema:

Era um homem bem vestido

Foi beber no botequim

Bebeu muito, bebeu tanto

Que saiu de lá assim.

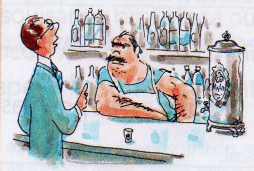

a) Você teria entendido de que maneira o homem saiu do botequim?

Resposta pessoal

Professor: espera-se que os alunos percebam que a palavra assim escrita normalmente não dà indicios da forma como o

b) Uma pessoa pode sair de um botequim de muitos jeitos. Pense em quatro formas diferentes de alguém sair de um botequim e complete os versos. Faça como o Millôr: use "efeitos especiais" para grafá-las! Resposta pessoal.

Professor, converse com os alunos sobre possiveis modos de uma pessoa sair de um botequim. Quanto maior a variedade de

\section{Que saiu de lá}

Que saiu de lá

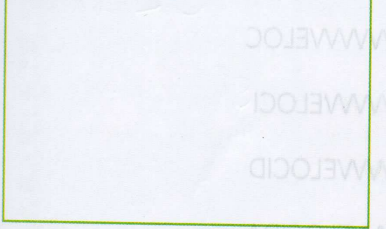

Que saiu de lá

Que saiu de lá

Parte 1 - Textos 13

\section{Ve Vocé é o autor}

Agora um desafio: escreva em uma folha avulsa um poema utilizando também algum "efeito especial".

Você poderá trazer de casa ou pesquisar na biblioteca outros poemas parecidos com os Poeminhas cinéticos. Assim, você conhecerá outras formas de organizar o poema no papel e ficará mais à vontade para usar a imaginação.

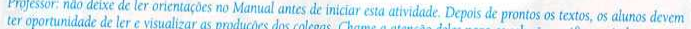




\begin{tabular}{|l|l|}
\hline Autor & SOARES, Magda Becker \\
\hline Nome da coleção & Português: Uma proposta para o letramento \\
\hline Editora & Moderna \\
\hline Gênero textual & Mito \\
\hline Páginas analisadas & 163 a 175 \\
\hline
\end{tabular}

\section{Seqüência para análise textual:}

Os textos escolhidos para análise encontram-se na unidade 4 do livro, que aborda o tema crendices brasileiras. Faz parte de uma sequiência com vários textos narrativos sobre o Saci Pererê, escritos por Monteiro Lobato (Tio Barnabé e o saci, retirado do livro O Saci, editora Brasiliense, 1994) e por Marcelo Xavier (O Saci-pererê, retirado do livro Mitos: o folclore do Mestre André, Editora Formato, 1997, p. 12 e publicado também no jornal $O$ Estado de Minas, de 30/10/98).

O trabalho enfoca o entendimento do texto e o contato com o mundo criado por Lobato em o Sítio do Picapau Amarelo, clássico da literatura nacional. Além da análise do vocabulário específico utilizado por Lobato, há reflexões sobre expressões regionais, típicas de quem mora na zona rural. Neste texto, o foco do trabalho também é a análise das descrições feitas durante as narrativas sobre os mitos do folclore brasileiro. O texto de Marcelo Xavier é apresentado somente para leitura, a fim de ampliar o repertório dos alunos.

\section{Seqüência para produção textual:}

A proposta prevê a descrição de um mito brasileiro, a partir da coleta de informações em diferentes fontes, inclusive orais. O próprio livro apresenta mais de uma descrição do Sacipererê para que o aluno tenha acesso a mais modelos de descrição de mitos.

Os alunos são orientados a fazer uma revisão no próprio texto com a ajuda do professor ou dos colegas e de incluir um desenho para acompanhar a descrição.

(Vide figura 3 - 5) 


\section{Comentário:}

A reprodução/paráfrase mais uma vez funciona como uma estratégia para auxiliar os alunos a escreverem e o gênero escolhido para tal atividade mostra-se adequado para a tarefa.

Os mitos são personagens fantásticos criados pela imaginação popular e que fazem parte do nosso folclore. Não teria como os alunos criarem um mito que não faz parte da tradição oral de um povo, portanto, pesquisar com os seus familiares ou em textos com informações sobre o tema condiz mais com a situação real em que esse gênero pode circular.

Ao reproduzir/parafrasear as informações sobre o Saci, os alunos estarão usando suas palavras e produzindo o próprio texto. Os modelos apresentados servem de base para que possam compor sua descrição, chamando a atenção para a necessidade de escreverem descrições físicas sobre o mito, que são complementadas pelo desenho, e destacar a presença de algum elemento ou poder mágico, característico do mito. 


\section{Figura 3 -5}

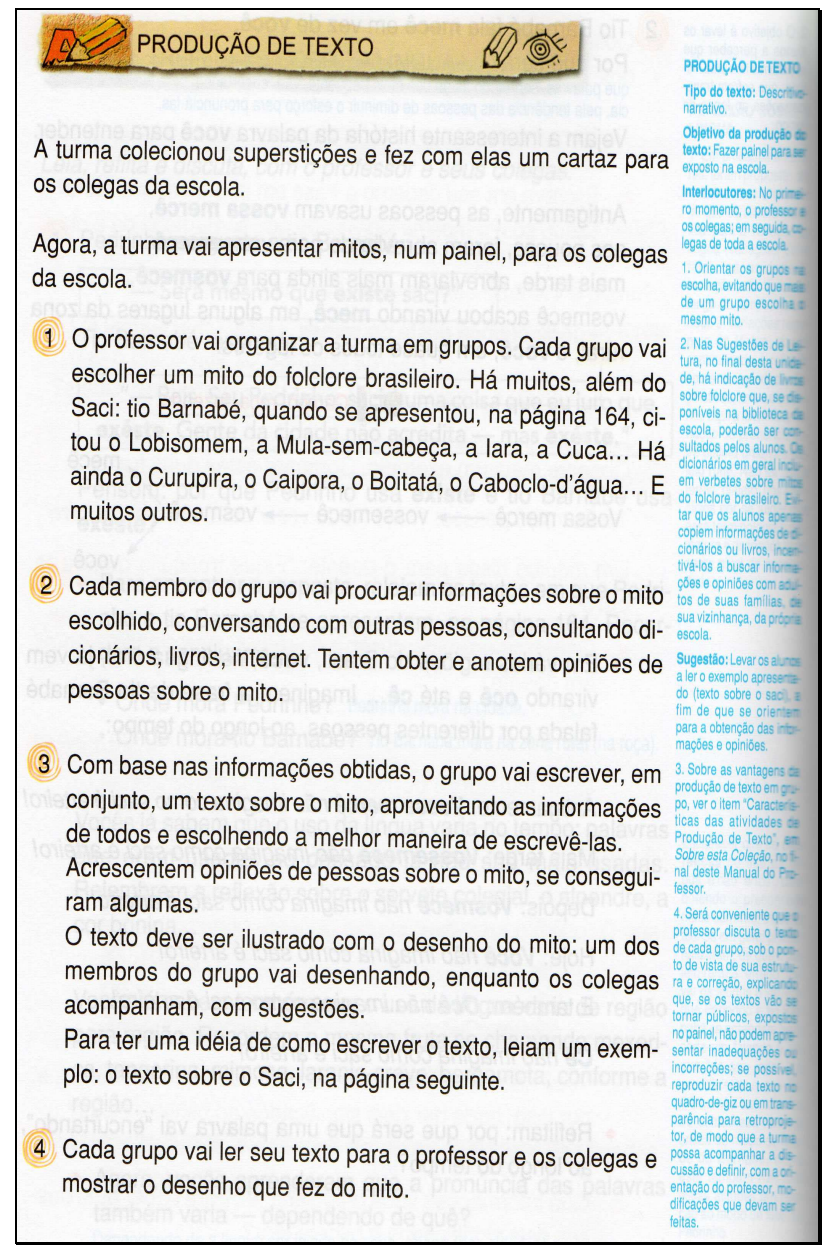

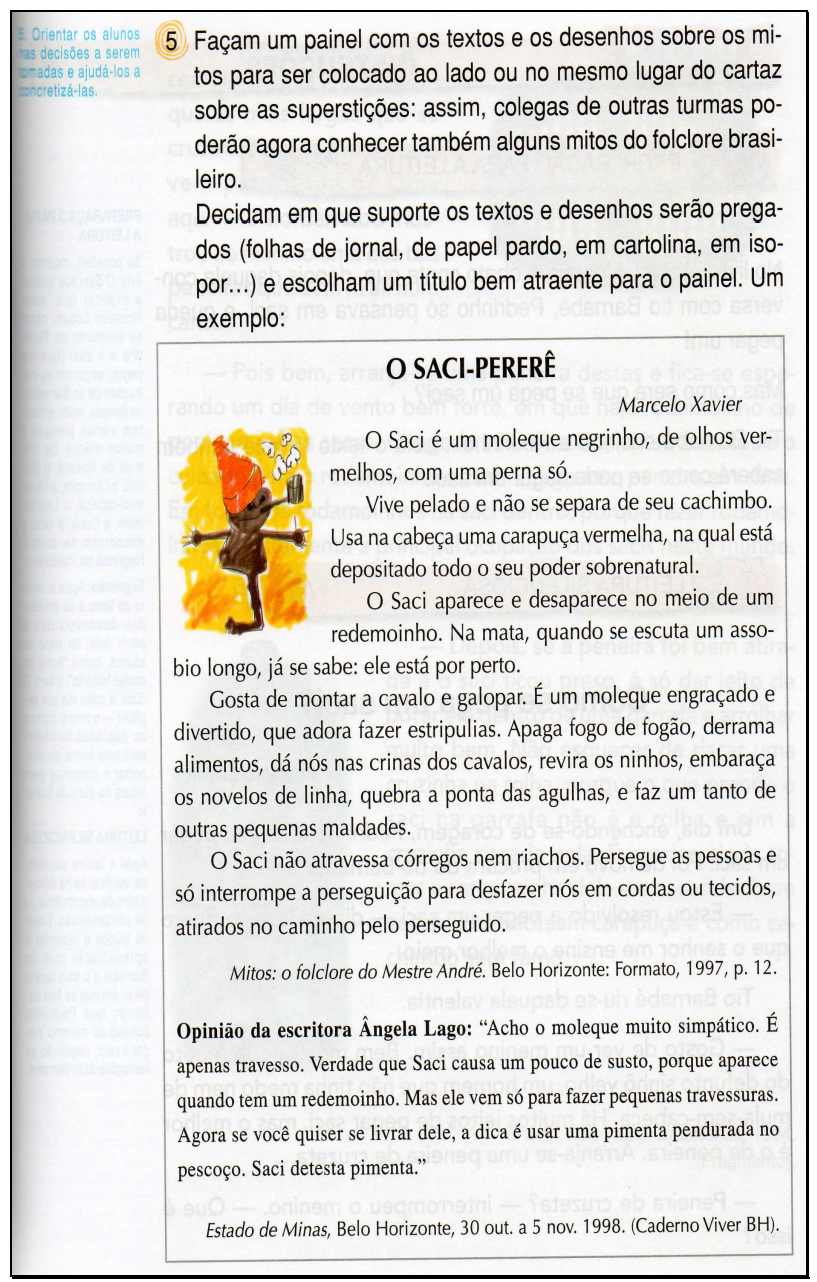




\begin{tabular}{|l|l|}
\hline Autor(es) & $\begin{array}{l}\text { CARPANEDA, Isabella Pessoa de Melo e BRAGANÇA, } \\
\text { Angiolina Domanico }\end{array}$ \\
\hline Nome da coleção & Porta Aberta: língua portuguesa \\
\hline Editora & FTD \\
\hline Gênero textual & Notícia \\
\hline Páginas analisadas & 186 a 193 \\
\hline
\end{tabular}

\section{Sequiência para análise textual:}

A sequência analisada tem a notícia como gênero de estudo e está presente na unidade 15 do livro. São apresentadas várias notícias como modelos, reais e publicadas em jornais ou revistas, dentre as quais destacamos $\mathrm{A}$ invasão das minhocas, publicada pelo jornal Cruzeiro do Sul, de 19/01/01 e O dia em que choveram sapos, publicada na revista Mundo estranho, de dezembro de 2003.

Além de questões relativas ao suporte e à pontuação empregada, principalmente nos casos em que ocorreram transcrições de depoimentos de entrevistados, em ambos os textos o foco da análise é a estrutura do lide, parágrafo inicial deste gênero. Dessa forma, a estrutura característica da notícia fica garantida, ao chamar a atenção dos alunos para o fato de que as notícias quase sempre respondem às questões onde, o que, quem, quando, como e por quê, referentes ao fato noticiado.

\section{Seqüência para produção textual:}

A proposta prevê a escrita de uma notícia sobre algum fato real que tenha ocorrido na comunidade para encaminhar ao jornal da escola. Um outro modelo é apresentado, destacando as informações que devem aparecer no lide e há também um pequeno roteiro para a revisão do texto, a fim de que os alunos possam melhorá-lo.

(Vide figura 3 - 6) 


\section{Comentário:}

Ao apresentar o gênero, o foco das questões envolve a observação da estrutura das notícias, principalmente seu parágrafo inicial, uma vez que este contém as principais informações sobre o assunto e outros são ampliações das idéias contidas nele.

O trabalho com as notícias segue o padrão já comentado anteriormente: os modelos analisados são a base para a escrita. Os alunos entram em contato com vários textos desse mesmo gênero e analisam seu conteúdo, sua estrutura e sua linguagem.

A partir dessa análise, são convidados a escrever um texto que tem uma estrutura fixa, na qual o como escrever já estará definido. Ao apresentar as perguntas características que deverão ser respondidas no lide, o aluno terá organizado a base para escrever seu texto.

Os modelos apresentados atuam como pistas para o escritor, que irá escrever o seu próprio texto de acordo com as suas escolhas e com o seu objetivo de comunicação. Indicar a forma de organizá-lo é uma maneira de monitorar essa tarefa, ajudando o aluno na tomada de decisões durante o processo de escrita. 
Figura 3 - 6

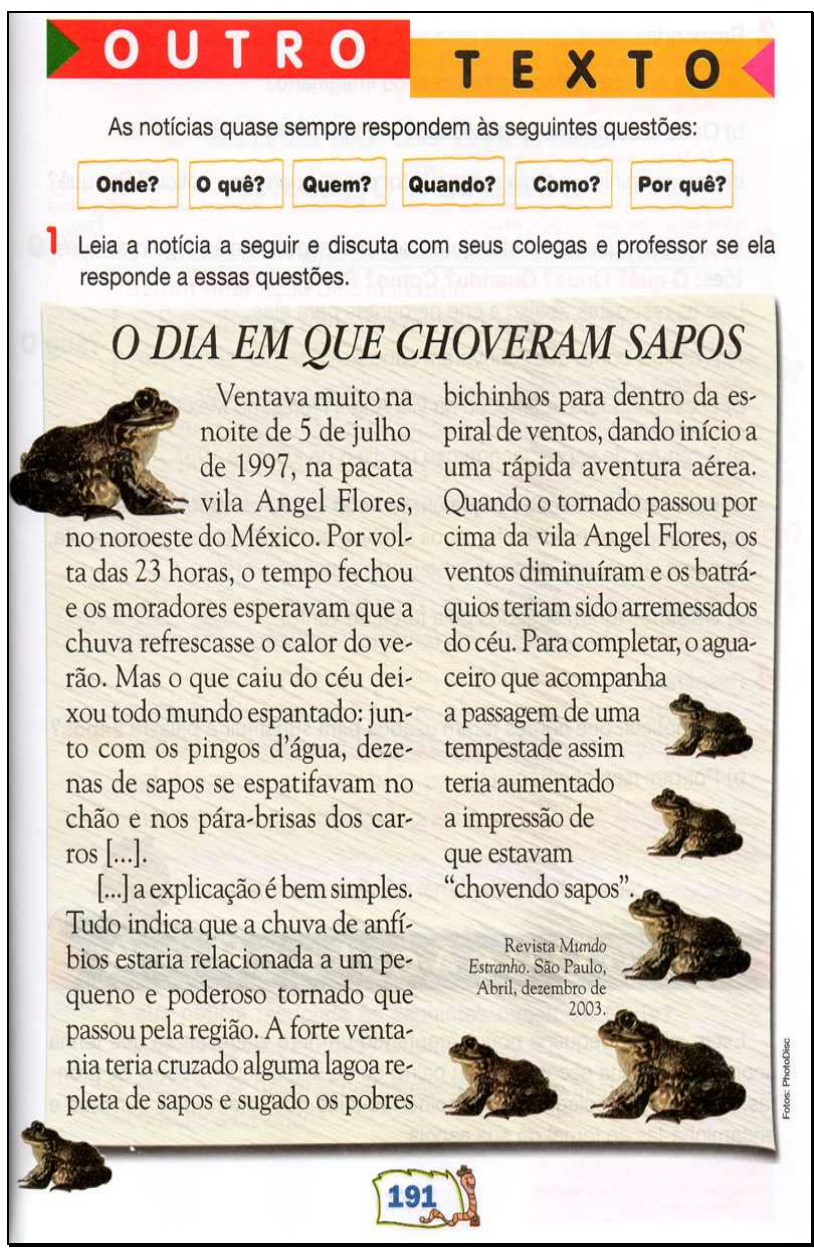

\section{Responda.}

a) Essa notícia relatou um fato real ou imaginário?

Relatou um fato real.

b) Onde essa notícia foi publicada?

Ela fol publicacia na revista Mundo Estranho

c) Na sua opinião, o título deixa o leitor curioso para ler a notícia? Por quê? Espera-se que os alunos respondam que sim, pois o tifulo "O dia em que choveram sapos" instiga o leitor a

3 Você já sabe que as notícias quase sempre respondem às seguintes questões: 0 quê? Onde? Quando? Como? Por quê? Quem?

Leia as respostas abaixo e crie perguntas para elas.

a) A notícia conta que "choveram sapos".

0 que a noticia conta?

b) $\mathrm{O}$ estranho fato aconteceu na vila Angel Flores, no México.

c) A "chuva de sapos" aconteceu no dia 5 de julho de 1997.

Quando aconteceu a "chuva de sapos"?

d) Esse fato aconteceu porque um tornado sugou os sapos de dentro de uma lagoa e, ao perder a força, os anfíbios acabaram caindo sobre a vila, dando a impressão de estar "chovendo sapos".

Por que esse fato aconteceu?

e) Os sapos foram sugados pela força do vento.

0 que aconteceu com os sapos?

4 Responda.

a) Na notícia, que nomes foram usados para substituir a palavra sapos? Foram usadas as palavras: anfibios, pobres bichinhos, batráquios.

b) Por que isso aconteceu?

Espera-se que os alunos concluam que essas substituiçōes

evitam a repeticaa da palavra sapos, fazendo com que a leitura

\section{P. RODUARES ER I A}

Escreva uma pequena notícia contando um fato interessante que tenha acontecido na sua escola, no seu bairro ou na sua cidade. Depois de prontas, você e seus colegas irão escolher aquelas que forem mais curiosas e encaminhá-las ao jornal da sua escola. 


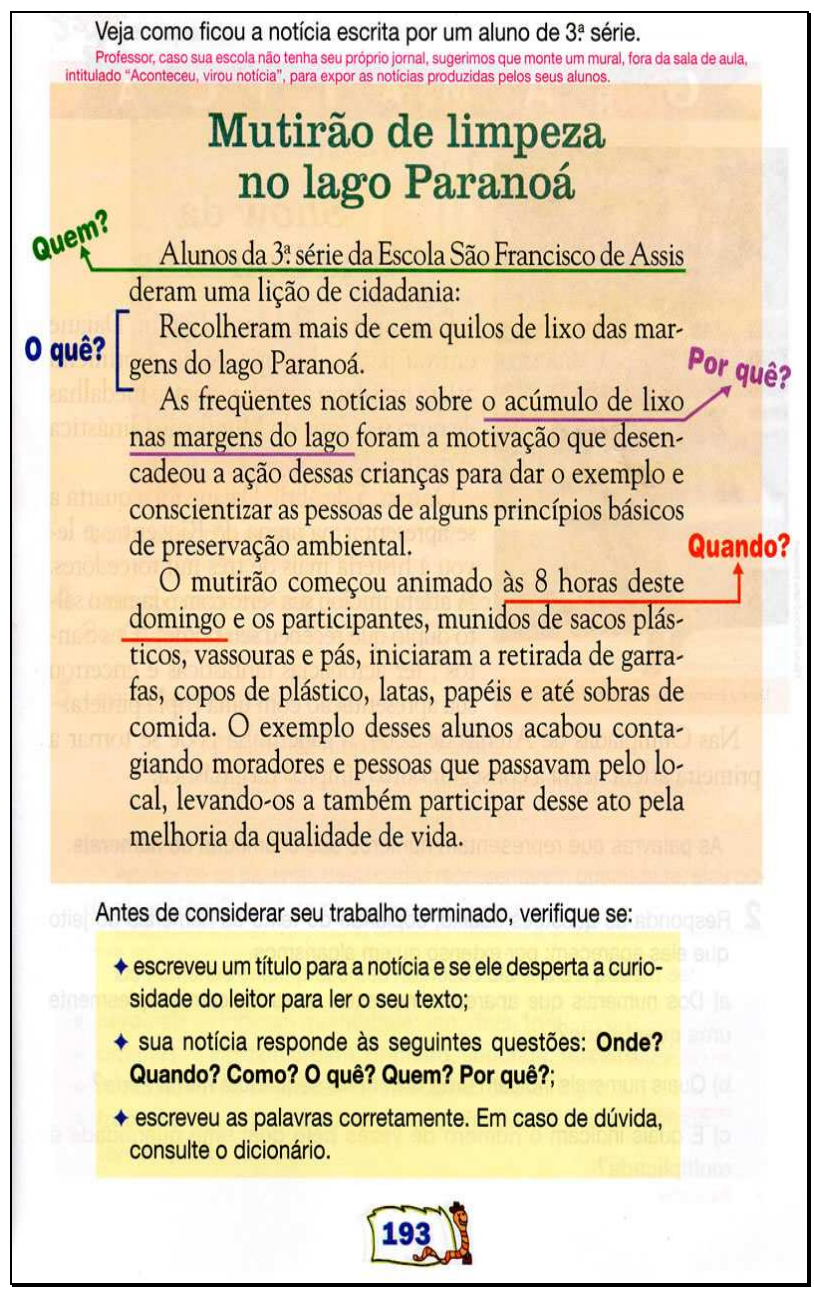




\section{$5^{\circ}$ ANO / $4^{\text {a }}$ SÉRIE}

\begin{tabular}{|l|l|}
\hline Autor(es) & $\begin{array}{l}\text { Obra coletiva concebida, desenvolvida e produzida pela } \\
\text { Editora Moderna }\end{array}$ \\
\hline Nome da coleção & Projeto Pitanguá \\
\hline Editora & Moderna \\
\hline Gênero textual & Conto africano \\
\hline Páginas analisadas & 60 a 70 \\
\hline
\end{tabular}

\section{Seqüência para análise textual:}

Apresentação do gênero por meio do texto $\mathrm{O}$ escravo que guardou os ossos do príncipe, retirado do livro Os príncipes do destino: histórias da mitologia afro-brasileira, de Reginaldo Prandi, Ed. Cosac \& Naify, 2001. Este texto faz parte da unidade 3 do livro, cujo tema são as profissões ou trabalhos encontrados em uma sociedade atual ou antiga.

As questões abordam a retomada dos acontecimentos da história, algumas inferências para melhor interpretar o texto e questões de opinião sobre a atitude da personagem, pois o foco é voltado para valores éticos de respeito às pessoas, independente de sua origem ou classe social.

Há também questões que chamam a atenção para aspectos de construção do texto, no que se refere aos tipos de narrador, pois uma história pode ser escrita em $1^{\text {a }}$ pessoa, em que o narrador também é personagem, e em $3^{\mathrm{a}}$ pessoa, em que o narrador é somente um observador. Os alunos devem perceber que esse fato pode gerar diferentes histórias, se forem contadas a partir de pontos de vista diversos.

\section{Sequiência para produção textual:}

Reescrever a história, alterando o narrador de $3^{\mathrm{a}}$ pessoa (narrador-observador) para $1^{\mathrm{a}}$ pessoa (narrador-personagem).

No caso, os alunos deverão fazer adaptações ao texto de forma a acrescentar as impressões e as emoções das personagens, de acordo com seu ponto de vista, mas não poderão alterar a sequência dos fatos.

(Vide figura 4 - 1) 


\section{Comentário:}

A idéia é propor uma reprodução/paráfrase do texto, alterando o ponto de vista do narrador, que passará de $3^{\mathrm{a}}$ para $1^{\mathrm{a}}$ pessoa do singular. Dessa forma, os alunos já estarão se baseando em alguma estrutura para o texto, ou seja, nas idéias de outrem e irão alterar apenas alguns trechos, acrescentando informações que não aparecem na história original para explicar as atitudes ou emoções da personagem escolhida para contar os fatos.

Há um roteiro para auxiliar na escolha do narrador e orientações para seguir a seqüência dos fatos já criada no conto original. Nessa proposta, os alunos estarão reescrevendo o texto, porém deverão recriar as situações a partir de um outro ponto de vista.

Não se trata de uma cópia do texto original, pois caberá aos alunos realizarem algumas inferências para contar os fatos de acordo com o ponto e vista da personagem escolhida. Cada aluno poderá criar uma nova história, com base na trama original. 
Figura 4-1

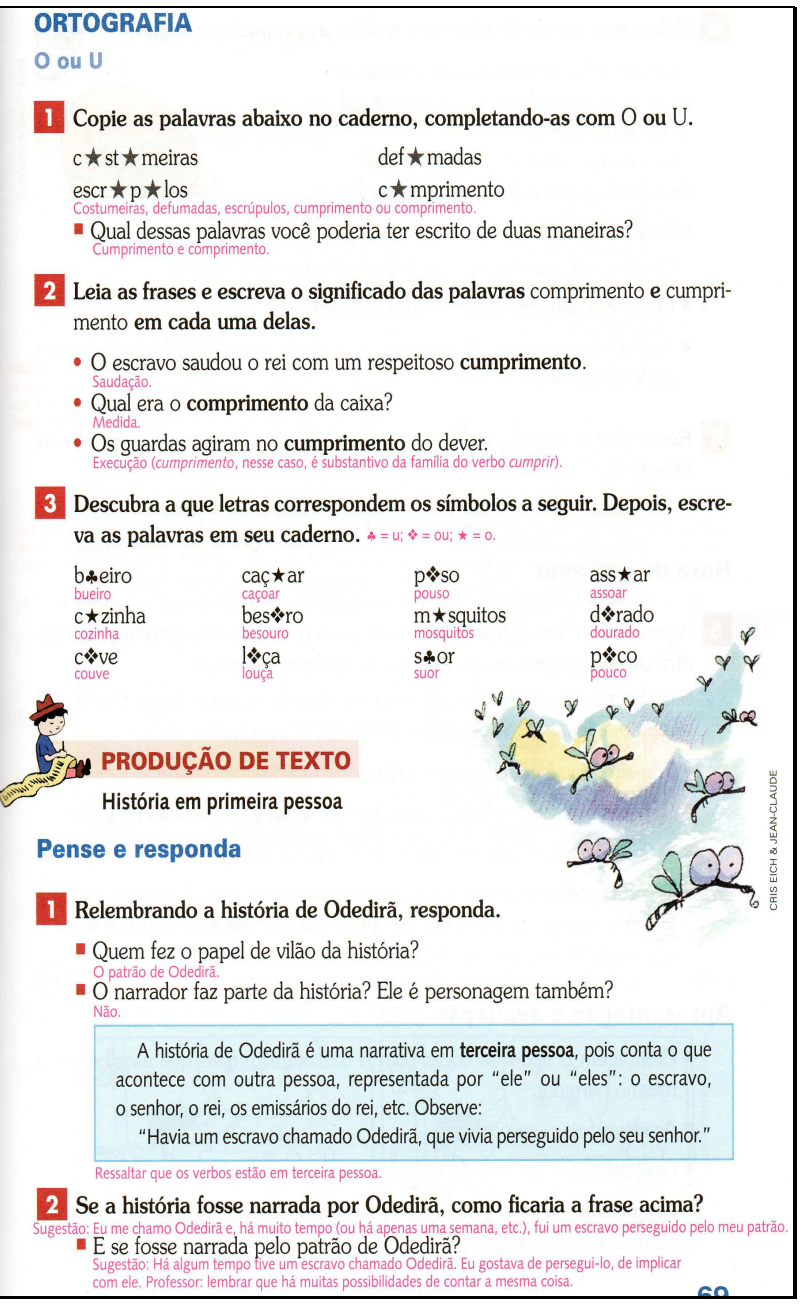

3 Releia este trecho da história e resolva as propostas a seguir.

"Um dia, voltando da roça, ele encontrou

todas as suas galinhas e todos os seus galos mortos.

O seu senhor disse:

'Tu és escravo ou dono de uma granja?'

Odedirã ficou tristíssimo, mas não disse nada."

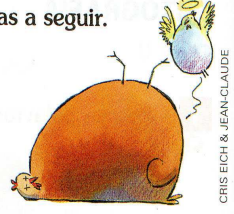

- Passe o trecho acima para a primeira pessoa. Ele pode começar assim:

Um dia, voltando da roça, encontrei todas as minhas galinhas... ... e todos o - Quem é o narrador no texto que você escreveu? Odedirâ.

- Acrescente, depois da última frase, alguma coisa que Odedirã não disse, mas pode ter pensado. Resposta pessoal. No texto original, o narrador não informa ao leitor tudo o que Odedir passa na mente de uma personagem, não e e preciso que o narrador seja em primeira pes-

4 Reescreva o mesmo trecho, tendo agora como narrador o patrão de Odedirã.

- Inclua tudo aquilo que ele poderia estar pensando ou sentindo. Sugestão: Um dia não agüentei aquele desrespeito e matei todos os galos e galinhas de Odedirã. Quando ele chegou e viu Hora de escrever escravo ou dono de uma granja?"." Mas percebi que ele não entendeu que não podia Professor: orientar os a Junos a larzerengar seu serviço e ficar se dedicando a seus interesses próprios à minha custa.

5 Agora, você e um colega irão reescrever a história toda, escolhendo Odedirã ou seu patrão como narrador em primeira pessoa.

Sua história circulará pela classe para ser lida pelos outros alunos. Empregue, portanto, a linguagem adequada aos leitores de seus textos.

- Primeiro, decidam quem será o narrador: Odedirã ou o patrão?

- Depois, resolvam oralmente cada trecho, antes de escrevê-lo no papel.

- O texto deve ser coerente com a história já conhecida.

- Tentem mostrar o que não apareceu na história original. Exemplos: por que Odedirã queria ser rei, o que ele pretendia com as suas atividades, ou o que o patrão sentiu ao ver Odedirã ser recompensado, etc.

\section{Apresentação e avaliação}

- Comparem o texto de vocês com o das outras duplas que escolheram o mesmo narrador

- As idéias foram parecidas?

- Qual deles revelou mais dados sobre a pessoa do narrador?

- Algum texto conseguiu transformar a imagem do vilão, tornando-o mais digno de compreensão? 


\begin{tabular}{|l|l|}
\hline Autor(es) & William R. Cereja e Thereza C. Magalhães \\
\hline Nome da coleção & Português: linguagens \\
\hline Editora & Atual \\
\hline Gênero textual & Texto de opinião \\
\hline Páginas analisadas & 141 a 151 \\
\hline
\end{tabular}

\section{Sequiência para análise textual:}

Em um primeiro momento os alunos irão analisar a transcrição de um debate regrado, feito por crianças acerca de um assunto polêmico: se filmes e games com cenas de violências levam o espectador ou jogador a ter comportamentos violentos. O texto, cujo título é Violência é o que atrai, foi publicado na Folhinha $\mathrm{n}^{\circ}$ 1893. As atividades fazem parte de uma unidade que traz diferentes textos com temas atuais acerca de valores com discussões que abordam o preconceito.

Há uma longa seqüência em que o texto é apresentado e questões de entendimento e de extrapolação, cujo objetivo é propor a manifestação das opiniões dos leitores. Depois, em uma outra seção do livro, os textos são retomados para que seja proposta a análise da estrutura de um texto de opinião. Nesse bloco, as questões propostas levam os alunos a perceberem que a principal característica desse gênero é a escolha de temas que gerem diferentes opiniões e a forma como são apresentados os argumentos para sustentá-las.

\section{Seqüência para produção textual:}

Em um primeiro momento os alunos trocarão idéias sobre o tema do debate lido e escolherão a sua opinião. Depois, pensarão em argumentos que sustentem suas idéias, para só depois escrever seu texto de opinião sobre o assunto.

Há orientações sobre a revisão do texto e sobre sua finalidade, cujo propósito é organizar uma campanha para viver melhor com os colegas e com o próprio ambiente.

(Vide figura 4 - 2) 


\section{Comentário:}

A escrita desse texto de opinião, na verdade, se aproxima muito da categoria reprodução/paráfrase, pois os alunos já terão produzido esse texto oralmente no momento em que estiverem realizando o debate.

A escrita do texto passa a ser uma forma de registrar o fato ocorrido e a própria opinião, com base em argumentos já expostos anteriormente.

Os autores do livro sugerem uma organização do texto em partes: apresentação do tema, da própria opinião, dos argumentos e por fim uma conclusão. O que escrever já estará colocado, cabendo aos alunos organizar as idéias.

Dessa forma é possível expressar a autoria, com base em um planejamento prévio. $\mathrm{O}$ modelo passa a ser o texto oral, que orienta a escrita e instrumentaliza o aluno sobre o que escrever. Caberá a ele organizar as idéias já colocadas, ressaltando a sua própria opinião. 


\section{Produgão de texto}

\section{DEBATE REGRADO PÚBLICO}

1. Um debate só ocorre quando há diferentes opiniões a respeito de um assunto. Os debatedores tentam convencer um ao outro com argumentos, isto é, apresentam as razões ou os motivos de pensarem daquela forma. No debate lido:

a) Em relação à questão inicial, predominaram posições a favor ou contra, isto é, os filmes e jogos influenciam ou não as pessoas?

Predominou a opiniäo de que influenciam, sim.

b) Ao término do debate, você acha que houve uma posição vencedora? Por quê?

Resposta pessoal. Talvez a posiçăo a favor tenha sido vencedora, pelo fato de ser maior o número de participantes que expressaram essa opiniäo.

2. Durante o debate público, é comum simpatizarmos com a opinião de alguém e passarmos também a defender aquele ponto de vista. Nesse caso, dizemos concordo com fulano... Se, ao contrário, discordamos, dizemos discordo de fulano... Podemos também ficar numa posição intermediária e, nesse caso, dizemos concordo em parte ou discordo em parte.

a) Qual é a opinião de André Maurício sobre a pergunta final, ou seja, se a imprensa também influencia a violência?

Ele acha que há influência, sim, desde que a pessoa tenha um instinto psicopata.

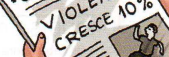

b) Compare a resposta de André Maurício à resposta que Emmanuil deu à primeira pergunta. Na sua opinião, André foi influenciado por Emmanuil?

Resposta pessol. Sugestâa: É: possivel que sim, pois o argumento é o mesmo.

c) Ele poderia ter dito: "concordo com a opinião de Emmanuil"?
3. Num debate, é comum haver a presença de um moderador ou mediador, isto é, uma pessoa que coordena o debate. 0 papel do moderador é dar a palavra a quem quer falar, controlar 0 tempo dos participantes, estimular o debate fazendo algumas perguntas relacionadas ao assunto, etc

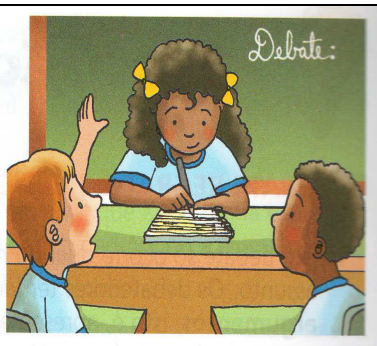

a) No debate lido, quem faz o papel de moderador?

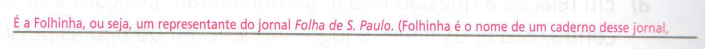
destinado às criancas

b) Quantas perguntas o moderador fez para estimular os alunos a falar? Sete perguntas.

4. Observe que, após cada pergunta, várias crianças falam, uma de cada vez. Como você acha que essa sequêencia de falas foi organizada durante 0 debate?

Provavelmente cada criança se inscreveu (levantando o braço, por exemplo) e esperou sua vez de falar

5. Reúna-se com seus colegas de grupo e, seguindo a orientação do professor, escreva no quadro abaixo as principais características de

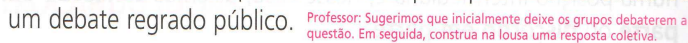

\section{O debate regrado público}

. Os participantes discutem um assunto polêmico e confrontam suas idéias ou pontos de vista

- Os debatedores têm a intençāo de convencer os outros; por isso apresentam argumentos.

- Um debatedor pode apoiar ou rebater a opiniäo de outro; para isso, utiliza expressóes como eu concordo com... ou eu discordo de fulano.

- Normalmente há a presença de um moderador que coordena os trabalhos, estimula os debatedores e cria condiç̄es para que todos tenham oportunidade de falar.

- A linguagem apresenta em geral algumas caracteristicas da expressāo oral. 
AGORA É A SUA VEZ Professor: Como os alunos ja realizaram um debate na abertura deste capitition

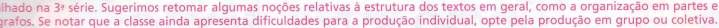

Você debateu com os colegas a influência de filmes e jogos violentos sobre o comportamento de crianças e adolescentes e leu a transcrição de um debate sobre essa questão. Que tal participar agora da produção de um texto de opinião? Siga estas instruções:

a) Primeiramente, tome uma posição sobre o assunto: Filmes e jogos podem influenciar crianças e jovens a se tornarem violentos?

b) Depois, entre os melhores argumentos apresentados no debate realizado na sala ou no debate transcrito, escolha dois ou três para fundamentar sua opinião sobre o assunto.

c) Organize o texto em partes.

Para isso, escreva um

parágrafo inicial,

apresentando sua opinião

sobre $o$ assunto. Depois,

escreva mais alguns,

explicando e desenvolvendo

sua opinião com base nos

argumentos selecionados. De

preferência, escreva um

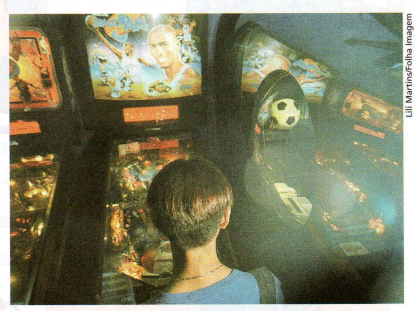

parágrafo para cada argumento. Por último, redija um parágrafo de conclusão para o texto. Nele, você poderá confirmar sua opinião, dar uma sugestão ou fazer um alerta.

d) Ao concluir o texto, dê um título interessante a ele.

e) Faça uma revisão do texto, observando se ele apresenta claramente a sua opinião sobre o assunto; se apresenta bons argumentos para explicar ou justificar sua opinião; se está organizado em parágrafos; se é capaz de convencer o leitor; se está de acordo com as normas ortográficas da língua. Altere o que for necessário.

f) Quando concluir, faça uma troca com um colega, de modo que um leia o texto do outro e apresente sugestões. Passe o texto a limpo, leia-o para a classe e guarde-o para expor durante a realização da campanha proposta no projeto da Oficina de Criação desta unidade. 


\begin{tabular}{|l|l|}
\hline Autor(es) & $\begin{array}{l}\text { SIMONCELLO, Vera Lucia, } \\
\text { ORCHIS, Amália e CHU, Angelina Verônica de Andrade. }\end{array}$ \\
\hline Nome da coleção & Registrando descobertas: língua portuguesa \\
\hline Editora & FTD \\
\hline Gênero textual & Artigo de opinião \\
\hline Páginas analisadas & 212 a 215 \\
\hline
\end{tabular}

\section{Sequiência para análise textual:}

A proposta encontra-se em uma seqüência do livro que tem como tema chegadas e partidas. Após analisar vários textos reais ou fictícios sobre pessoas que partiram dos seus locais de origem, a proposta prevê um debate sobre a questão dos deslocamentos populacionais. A seqüência segue os mesmos passos já descritos anteriormente: uma pesquisa sobre o assunto para se preparar para o debate, uma sequiência que orienta o debate oral e o registro, por escrito, da própria opinião.

\section{Seqüência para produção textual:}

A proposta prevê a escrita de um texto de opinião sobre o assunto do debate. Há várias etapas que alternam momentos orais e escritos para ajudar na organização e troca de pontos de vista. Em um primeiro momento, os alunos irão posicionar-se em relação ao tema e justificar, por escrito, sua decisão. Em seguida, devem pesquisar mais informações sobre o que irão defender, ampliando seus argumentos. Novamente é solicitado um registro dos fatos pesquisados que reforcem sua opinião. A etapa seguinte é o debate oral, também seguido de registro escrito do que foi discutido. Por fim, os alunos colocam sua opinião novamente, concordando ou não com as discussões do grupo.

(Vide figura 4 - 3) 


\section{Comentário:}

O texto de opinião é um gênero que exige estudo e preparação antes da escrita, pois não se trata de simplesmente colocar sua opinião, mas sim de justificá-la perante um grupo usando argumentos convincentes.

No caso da proposta apresentada, a seqüência é dividida em partes para facilitar o trabalho do aluno. A cada etapa do trabalho, as atividades orais são registradas por escrito, o que garante que os alunos tenham onde se apoiar para melhor organizar as idéias. O que será escrito já estará definido, cabendo aos alunos organizar a forma.

O artigo de opinião é um gênero que favorece a autoria, pois cada um irá colocar as suas idéias do seu jeito. Ao mesmo tempo, estarão recebendo ajuda para fazê-lo, não sendo uma atividade sem modelos para se apoiar. O texto oral, servirá sempre de base e, por conseguinte, de modelo, para a tarefa de escrita. A cada troca de idéias em sala, a cada pesquisa sobre o que outras pessoas pensam sobre o assunto, mais instrumentos o aluno terá para escrever seu próprio texto; as idéias serão suas, porém baseada em modelos com os quais ele tiver contato. 


\section{Figura 4-3}

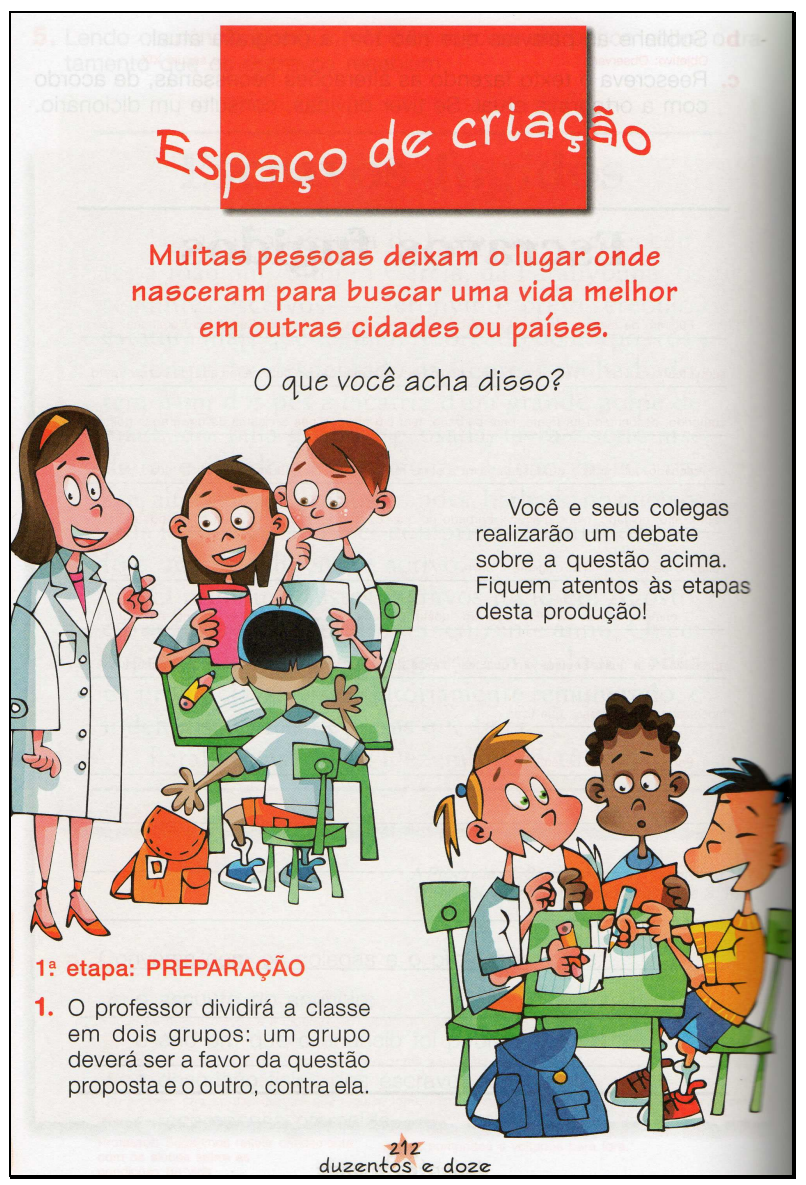

a. Escolham a posição (favorável ou contrária) que sua equipe defenderá.

b. Escrevam pelo menos três razões que expliquem a posição a ser defendida.

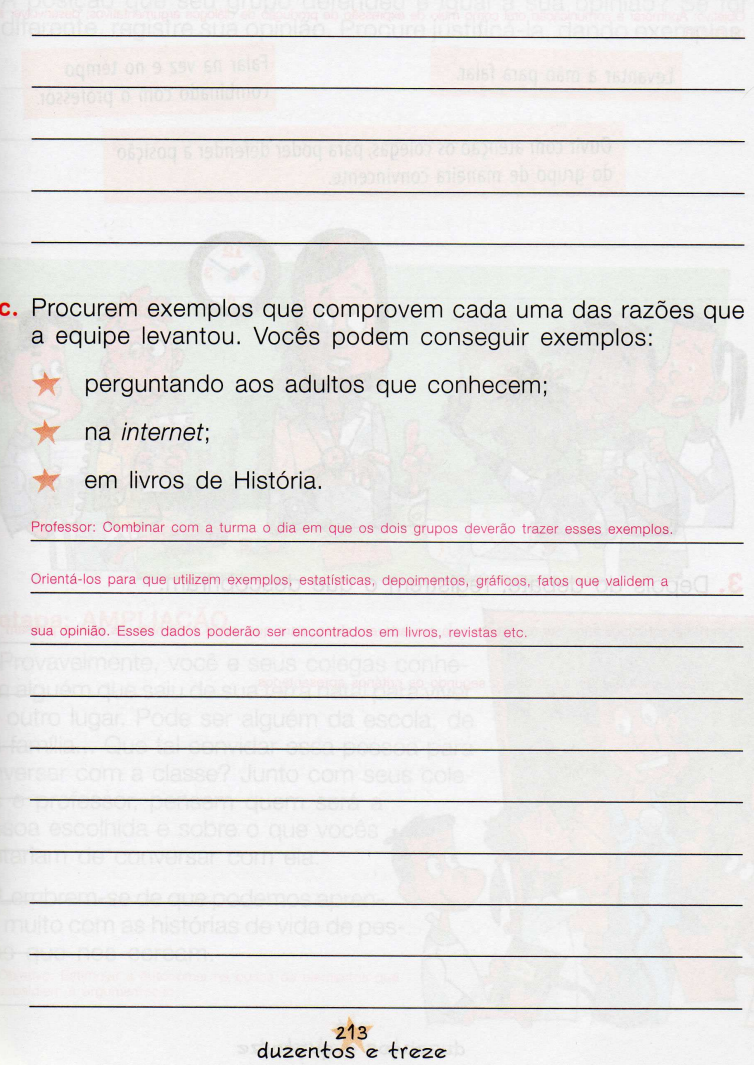




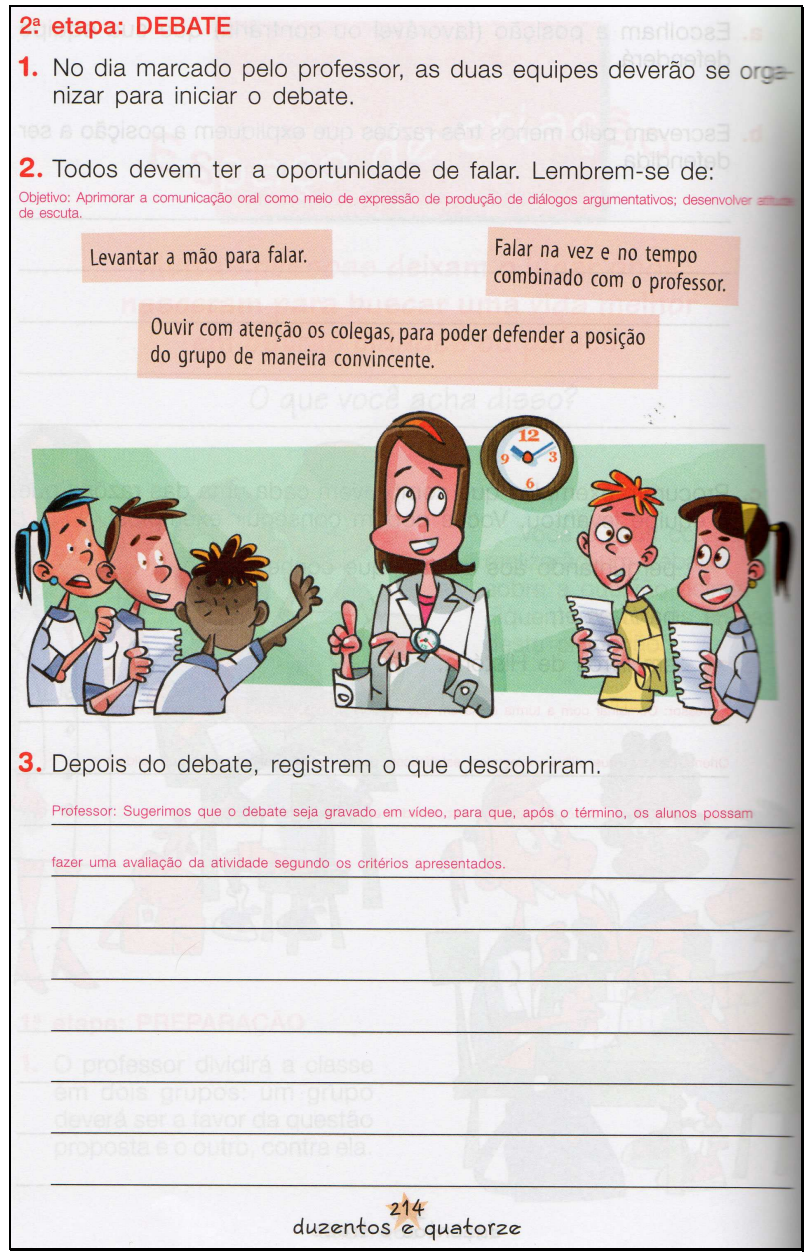

2. etapa: DEBATE

No dia marcado nizar para iniciar o debate.

Todos devem ter a oportunidade de falar. Lembrem-se de: Objetivo: A
de escuta.

3. Depois do debate, registrem o que descobriram

Professor: Sugerimos que o debate seja gravado em vídeo, para que, após o término, os alunos possa

\section{3a. etapa: AVALIAC̄̃̃O \\ Agora vamos ver como foi o debate.}

1. Que equipe defendeu melhor o ponto de vista escolhido? Por quê?

2. A posição que seu grupo defendeu é igual a sua opinião? Se for diferente, registre sua opinião. Procure justificá-la, dando exemplos.

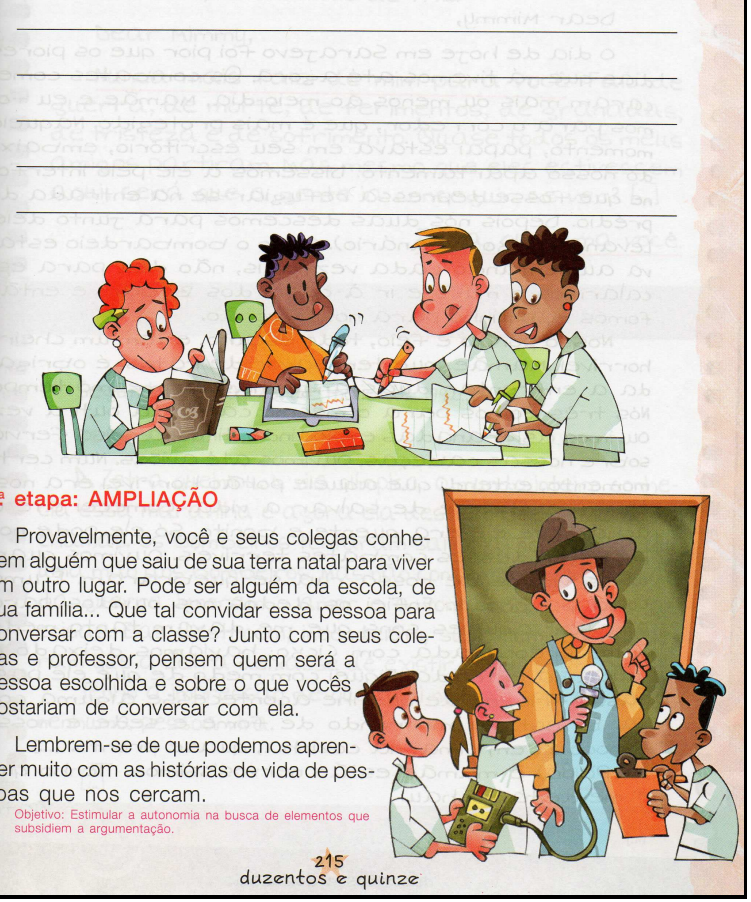




\begin{tabular}{|l|l|}
\hline Autor(es) & $\begin{array}{l}\text { PANACHÃO, Débora, CARVALHO, Carmen Silvia Cintra } \\
\text { Torres, KUTNIKAS, Sarina Bacellar, SALMASO, Silvia } \\
\text { Maria de Almeida e BARALDI, Maria da Graça Barreto. }\end{array}$ \\
\hline Nome da coleção & Construindo a escrita \\
\hline Editora & Ática \\
\hline Gênero textual & Descrição \\
\hline Páginas analisadas & 25 a 31 \\
\hline
\end{tabular}

\section{Sequiência para análise textual:}

O texto escolhido para análise é uma descrição de um menino, cuja estrutura se baseia nas ações, gestos e gostos de um menino que evidencia a visão que o autor tem sobre ele, ou seja, a visão de um adulto. Trata-se do texto O que é um menino, escrito por Alan Beck.

A análise é encaminhada para que os alunos percebam que a descrição não é isenta, pois apresenta os fatos a partir de um ponto de vista. A caracterização do menino é intercalada com as impressões do autor e permeada de comparações, poéticas ou não, com outros elementos. A análise se concentra, portanto, na percepção de um estilo e não somente do tipo de texto, pois a forma como a descrição é feita permite que se perceba a construção de um sentido e não somente de uma personagem.

\section{Seqüência para produção textual:}

A proposta prevê a reprodução/paráfrase do texto lido, porém os alunos deverão escolher uma outra personagem para escrever seu próprio texto.

Deverão descrevê-la a partir do seu ponto de vista para traduzir novas imagens sobre um adulto, uma menina, um pai, uma mãe etc.

(Vide figura 4 - 4) 


\section{Comentário:}

A reprodução/paráfrase, categoria de produção em que foi baseada essa atividade, implica em um trabalho no qual os alunos irão apoiar-se em um modelo para criar seu próprio texto. Não se trata de uma cópia, mas de basear-se em um modelo para apropriar-se de um estilo de escrever. É possível descrever uma personagem de forma poética, bem humorada, ou mais informativa, concentrando-se nos aspectos físicos. O modelo escolhido apresenta o primeiro formato e dá pistas aos alunos sobre como escrever, para que consigam apropriar-se de um estilo.

A fim de que cumpram esse propósito, deverão conservar o que for possível do texto original, alterando as comparações de modo a construir imagens diferentes que traduzirão o que é, por exemplo, uma menina a partir do seu próprio ponto de vista. Ao proceder dessa forma, estarão exercendo sua autoria, pois o que está em jogo é a linguagem utilizada, já que a escolha de cada palavra e de cada comparação feita permitirá a produção de trabalhos diferentes.

Mesmo transcrevendo trechos e seguindo uma mesma sequência presente no texto tido como modelo, cada aluno poderá expressar suas idéias de forma diferenciada ao escolher determinadas comparações que evidenciam algum aspecto mais marcante, de acordo com a sua ideologia e interpretação. 


\section{Figura 4 - 4}

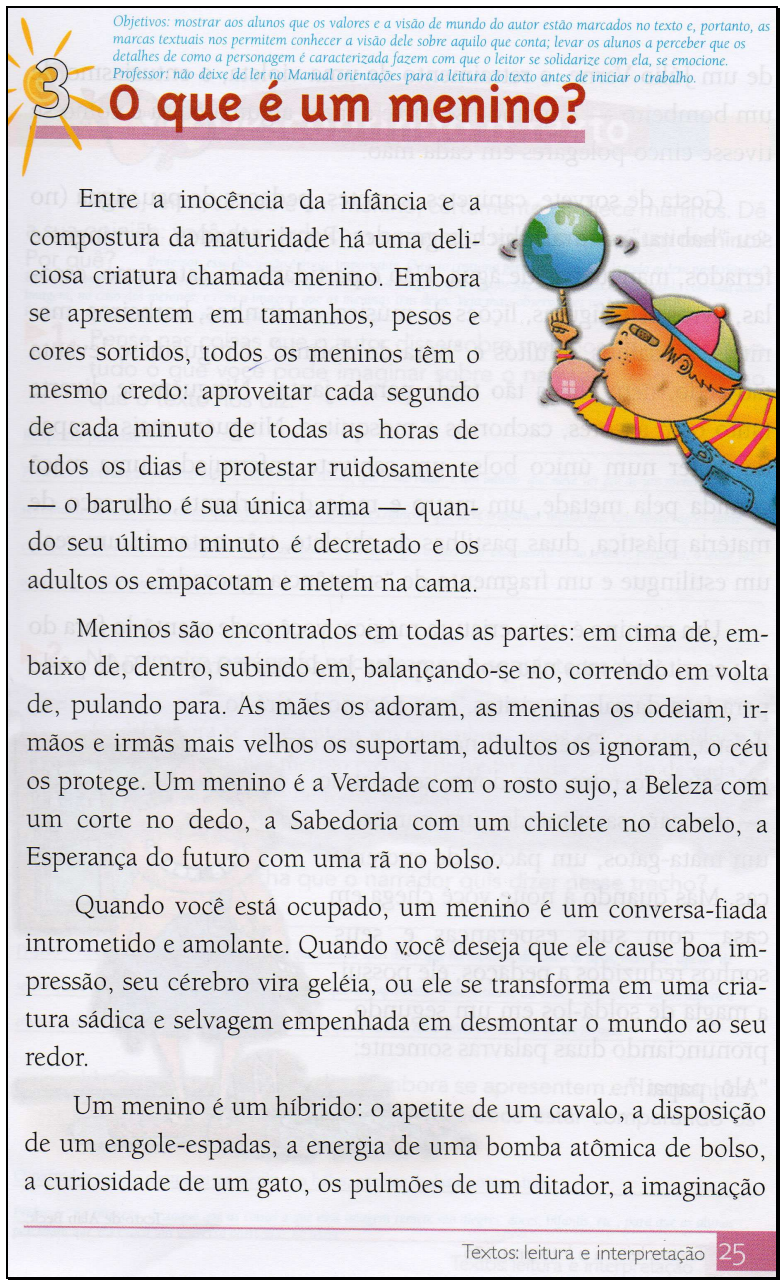

de um Júlio Verne, o retraimento de uma violeta, o entusiasmo de um bombeiro - e quando se mete a fazer alguma coisa é como se tivesse cinco polegares em cada mão.

Gosta de sorvete, canivetes, serrotes, pedaços de pau, água (no seu "habitat" natural), bichos grandes, Papai, sábados, domingos e feriados, mangueiras de água. Não é partidário de catecismo, escolas, livros sem figuras, lições de música, colarinhos, barbeiros, meninas, agasalhos, adultos e "hora de dormir". Ninguém se levanta tão cedo, nem chega tão tarde para o jantar. Ninguém se diverte tanto com árvores, cachorros e mosquitos. Ninguém mais é capaz de meter num único bolso um canivete enferrujado, uma maçã comida pela metade, um metro e meio de barbante, um saco de matéria plástica, duas pastilhas de chiclete, três notas de um real, um estilingue e um fragmento de "substância ignorada".

Um menino é uma criatura mágica: você pode mantê-lo fora do seu escritório, mas não pode expulsá-lo de seu coração. Pode pô-lo para fora da sala de visitas, mas não pode tirá-lo de sua mente. Queira, ou não, ele é seu captor, seu carcereiro, seu dono, seu patrão - um cara sarapintado, um nanico, um mata-gatos, um pacote de encrencas. Mas quando à noite você chega em casa, com suas esperanças e seus sonhos reduzidos a pedaços, ele possui a magia de soldá-los em um segundo, pronunciando duas palavras somente: "Alô, papai!"...

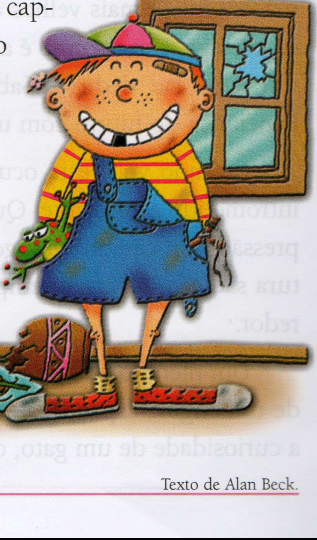


b) Esse trecho pode ser escrito de forma detalhada, como fez o autor, ou resumida, como você fez. Que diferença faz, para o leitor, o texto estar escrito de um jeito ou de outro? Resposta pessoal.

Objetivo: levar os alunos a perceber que, ao dar decalhes, a autor permite ao letitor construir uma imagem mais precisa e pessoal do objeto descrito

7. Releia com atenção o último parágrafo do texto. Que sentimentos o autor revela aí?

Nesse parágrafo o autor mostra o quanto gosta dos meninos, revela seu carinho, seu amor por eles.

Professor: pode acontecer de al gumas criancas acharem que o autor critica os meninos porque diz que säo agitados, etc. Caso scer outra, ou seja, dizer que sáo agitados näo significa nẫo gostar deles.

8. Você acha que, ao escrever esse texto, o autor estava pensando em um menino qualquer ou em um menino especial? Por quê? Resposta pessoal.

Bem, agora você sabe mais alguns "truques" para traduzir por escrito uma história ou uma idéia. Pegue seu Diário de Descobertas e escreva todos eles!

\section{Você é o autor}

Chegou a sua vez! Vamos propor que você produza um texto da seguinte forma: escolha um dos temas abaixo e escreva sobre ele conservando o que for possivel do texto do Alan Beck, mas alterando o que for necessário para traduzir novas imagens:

- O que é um adulto?

- O que é uma menina?

- O que é um pai?

- O que é uma mãe?

Textos: leitura e interpretação 31 


\begin{tabular}{|l|l|}
\hline Autor & SOARES, Magda Becker \\
\hline Nome da coleção & Português: Uma proposta para o letramento \\
\hline Editora & Moderna \\
\hline Gênero textual & Carta \\
\hline Páginas analisadas & 70 a 80 \\
\hline
\end{tabular}

\section{Seqüência para análise textual:}

A sequência analisada tem a carta como gênero de estudo e está presente na unidade 2 do livro, que tem como tema as formas que utilizamos para nos comunicarmos a distância. São apresentadas várias cartas como modelos, reais e escritas por leitores comuns, ao famoso escritor Monteiro Lobato. Todas fazem parte do acervo do IEB/USP.

As atividades têm como objetivo verificar a compreensão do texto, da sua estrutura e do uso de expressões típicas para iniciar-se ou terminar uma carta, de acordo com o interlocutor/destinatário.

\section{Sequiência para produção textual:}

A proposta prevê a escrita de uma carta para um escritor reconhecido, assim como as que foram lidas nos modelos apresentados. São sugeridos temas sobre o que escrever na carta e relembrados alguns aspectos da estrutura desse gênero, para garantir a organização do texto.

(Vide figura 4 - 5) 


\section{Comentário:}

Ao apresentar o gênero, uma das questões envolve a comparação com outras cartas já lidas anteriormente, no que se refere aos diferentes destinatários e à linguagem empregada.

$\mathrm{O}$ fato de os alunos entrarem em contato com esses modelos possibilita que façam escolhas sobre a melhor forma de produzir a saudação e a despedida, de acordo com a situação de interlocução. No caso, expressões mais formais como prezado senhor ou atenciosamente, típicas de situações que envolvem interlocutores não tão íntimos, não são recorrentes no universo infantil e precisam ser apresentadas aos alunos.

A estrutura da carta, apesar de fixa, possibilita inúmeras escolhas, que acabam sendo únicas. Se os alunos não tivessem o contato com esses modelos, provavelmente não teriam ferramentas para escrever seus textos.

Nos textos apresentados, é possível reconhecer também um assunto recorrente: comentários sobre as histórias lidas ou sobre as personagens, pois os destinatários são escritores renomados e os remetentes seus fãs. Essa também é uma dica sobre o que escrever, uma vez que os alunos irão escrever para alguém que não conhecem pessoalmente e com o qual não possuem intimidade.

$\mathrm{O}$ aceso aos modelos permite que os alunos sigam uma seqüência, garantindo que o texto fique bem escrito e organizado, ao mesmo tempo em que exercem a sua autoria. 
Figura $4-5$

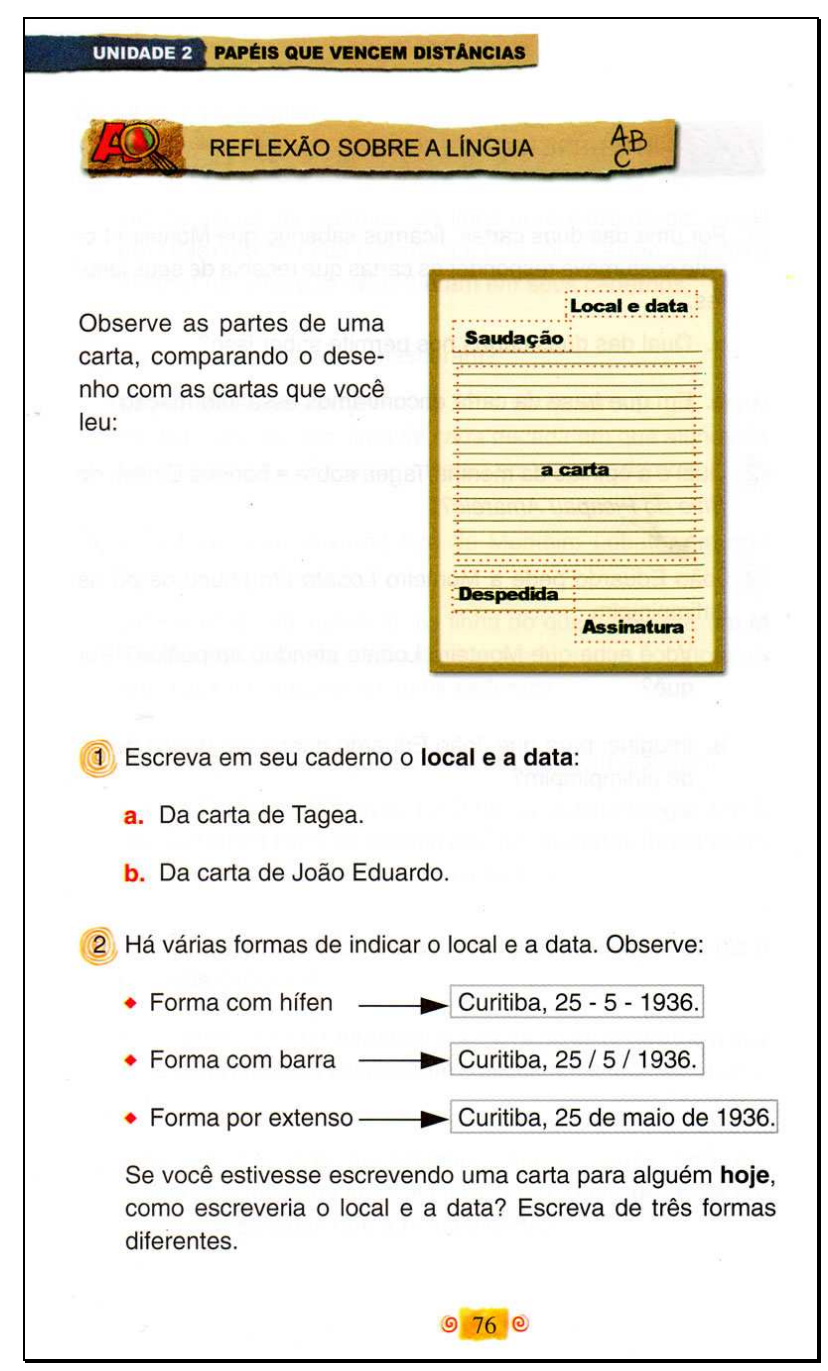

(3) Escreva, em seu caderno, a saudação:

a. Da carta de Tagea.

b. Da carta de João Eduardo.

(4) Imagine três pessoas diferentes escrevendo carta para Monteiro Lobato - o nome completo dele é José Bento Monteiro Lobato.

Leia as três saudações abaixo, e identifique, no quadro da direita, quem escreveria cada saudação:

\section{José Bento, \\ agradeço imensamente...}

Meu querido amigo:

Agradeço imensamente..

Prezado escritor Monteiro Lobato: Agradeço imensamente...

(5) Escreva, em seu caderno, a saudação que você usaria:

a. Em uma carta para um grande amigo ou amiga.

b. Em uma carta para o prefeito de sua cidade.

c. Em uma carta para o diretor (ou diretora) de sua escola.

6 Escreva, em seu caderno, a despedida:

a. Da carta de Tagea.

b. Da carta de João Eduardo. 
7. Para quem você escreveria cada despedida abaixo:

a. Um beijo, e comporte-se bem.

b. Abração, e vê se responde logo, tá?

c. Com minha admiração e respeito,

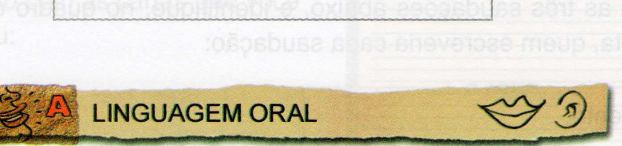

Vocês vão fazer como Tagea e João Eduardo: escrever uma carta para um escritor.

Mas, antes, é preciso escolher o escritor para quem a carta será escrita.

1) Votação secreta! Primeiro turno!

Cada um vai escolher o escritor para quem gostaria de escrever uma carta, recordando os livros que leu, aqueles de que mais gostou, o escritor a quem gostaria de dizer alguma coisa. Escrevam o nome do escritor escolhido numa cédula: um pedacinho de papel, que deve ser dobrado em quatro.

O professor vai recolher os votos.

2. A turma vai escolher uma Comissão de Apuração: três ou quatro colegas para abrir os votos e registrar, no quadro-degiz, os resultados.

(3) Os dois ou três escritores que receberam mais votos devem ser apresentados e defendidos por aqueles que votaram neles. O objetivo é convencer os colegas a escolher o seu candidato.
A turma pode fazer perguntas, durante a apresentação e defesa de cada candidatura.

Obedeça às regras de apresentação e debate:

Para falar, peça a palavra e espere sua vez.

Ouça com atenção e respeito a exposição dos colegas.

(1. Defenda seu escritor, mas respeite a opinião de seus colegas.

(4) Nova votação secreta! Segundo turno!

Cada um vai votar de novo, numa cédula, em um dos dois ou três escritores que ganharam no primeiro turno.

O professor vai recolher os votos.

(5) A turma vai escolher uma nova Comissão de Apuração para abrir os votos, registrar, no quadro-de-giz, os resultados e declarar o vencedor. Para ele é que a carta será escrita na atividade de Produção de Texto.

\section{Q. PRODUÇÃO DE TEXTO}

Vocês vão escrever em conjunto a carta para o escritor escolhido por votação, na atividade de Linguagem Oral.

(1) Primeiro, vocês vão resolver o que é que vão escrever:

- Dar ao escritor idéias para que escreva novas histórias, como fez Tagea?

- Falar o que vocês acham dos livros que ele escreveu, como fez João Eduardo?

- Falar dos personagens das histórias que ele escreve?

- Ou... Há muitas coisas mais sobre as quais vocês podem escrever.

$$
\text { () } 79 \text { (อ) }
$$


2 A turma vai dando sugestões sobre o quê e como escrever e, com a orientação do professor, vão sendo escolhidas as meIhores idéias e formas para escrever cada parte: local e data, saudação, o texto da carta, a despedida.

O professor vai escrevendo no quadro-de-giz a carta. Cada um de vocês deve ir escrevendo também a carta em seu caderno.

3 Depois de pronta a carta, releiam, aperfeiçoem, mudem alguma palavra ou frase, se acharem necessário.

4 Agora, escrevam o endereço do escritor, tal como deve aparecer no envelope. O professor vai escrevendo no quadro, vocês vão escrevendo também em seu caderno. Não se esqueçam das regras dos Correios para o endereçamento.

Como conseguir o endereço?

Vocês podem enviar a carta para a editora dos livros ou de um dos livros do escritor. Há escritores que publicam em uma só editora, há escritores que publicam em várias editoras neste último caso, escolham uma delas. Nos livros, aparece sempre o endereço da editora. As editoras sempre encaminham as cartas aos escritores.

5 Providenciem papel de carta e envelope e escolham quem vai copiar a carta e sobrescritar o envelope.

6 Decidam quem vai postar (pôr no correio) a carta: aquele que mora perto de uma agência dos Correios... ou que tem alguém que pode levá-lo a uma agência...

Quem for postar a carta deve, depois, contar à turma tudo que foi preciso fazer e como foi feito.

Agora... É esperar para ver se o escritor escolhido é como Monteiro Lobato: responde às cartas que recebe... 


\begin{tabular}{|l|l|}
\hline Autor(es) & $\begin{array}{l}\text { CARPANEDA, Isabella Pessoa de Melo e BRAGANÇA, } \\
\text { Angiolina Domanico }\end{array}$ \\
\hline Nome da coleção & Porta Aberta: língua portuguesa \\
\hline Editora & FTD \\
\hline Gênero textual & Conto tradicional \\
\hline Páginas analisadas & 107 a 113 \\
\hline
\end{tabular}

\section{Sequiência para análise textual:}

A sequência analisada apresenta uma continuação para um conto tradicional e encontrase na unidade 8 do livro. $\mathrm{O}$ texto apresentado como modelo é $\mathrm{O}$ príncipe desencantado, escrito por Flavio de Souza e retirado do livro Príncipes e princesas, sapos e lagartos, publicado pela editora FTD, em 1993.

Devido às características da faixa etária dos alunos, não foi apresentado o conto tradicional, mas sim uma versão modificada, guardando as características desse gênero, como, por exemplo, a presença de uma princesa, de um príncipe, de elementos mágicos, castelos etc.

Os alunos irão analisar a estrutura típica desses contos e as formas características de marcar o tempo, com expressões tais como: era uma vez e viveram felizes para sempre.

Um outro aspecto analisado auxilia os alunos a perceberem como foi criado o humor no texto, adaptando costumes atuais a textos e personagens típicos de uma outra época.

\section{Seqüiência para produção textual:}

A proposta prevê a escrita de uma paródia para o conto tradicional Os Três Porquinhos. Além dos temas apresentados para facilitar a escrita, há uma retomada da estrutura clássica da narrativa, com foco para a criação de um conflito e de um desfecho para a história, acrescentando um pouco de humor.

(Vide figura 4 - 6) 


\section{Comentário:}

Ao apresentar o gênero, uma das questões envolve a comparação com o conto original, conhecido pelas crianças. Só dessa forma conseguirão compreender as intenções do autor do texto analisado, cujo principal objetivo é modificar um conto, criando efeitos com humor.

O modelo, nesse caso, funciona em duas frentes: em um primeiro momento o conto original oferece pistas sobre o que escrever, retomando uma estrutura que é a base da narrativa. Em um segundo momento, ao analisar a paródia apresentada como modelo, é possível perceber como o autor do texto conferiu-lhe humor, a partir de um final que não é típico desses contos.

Os encaminhamentos para a escrita retomam a estrutura do texto, orientando as informações que devem aparecer, tais como a presença de um conflito e de seu desfecho. Além disso, há pistas sobre qual parte da história poderá ser modificada para garantir o humor. No conto analisado, o príncipe é "desencantado", pois em vez de acordar a princesa, a faz dormir novamente. Na sugestão de parodiar os porquinhos, há também a proposta da inversão de papéis: o lobo passa a ser o bonzinho e os porquinhos serão os malvados.

O modelo neste caso ajuda o aluno a escrever a sua própria versão para um conto tradicional. 
Figura 4 - 6

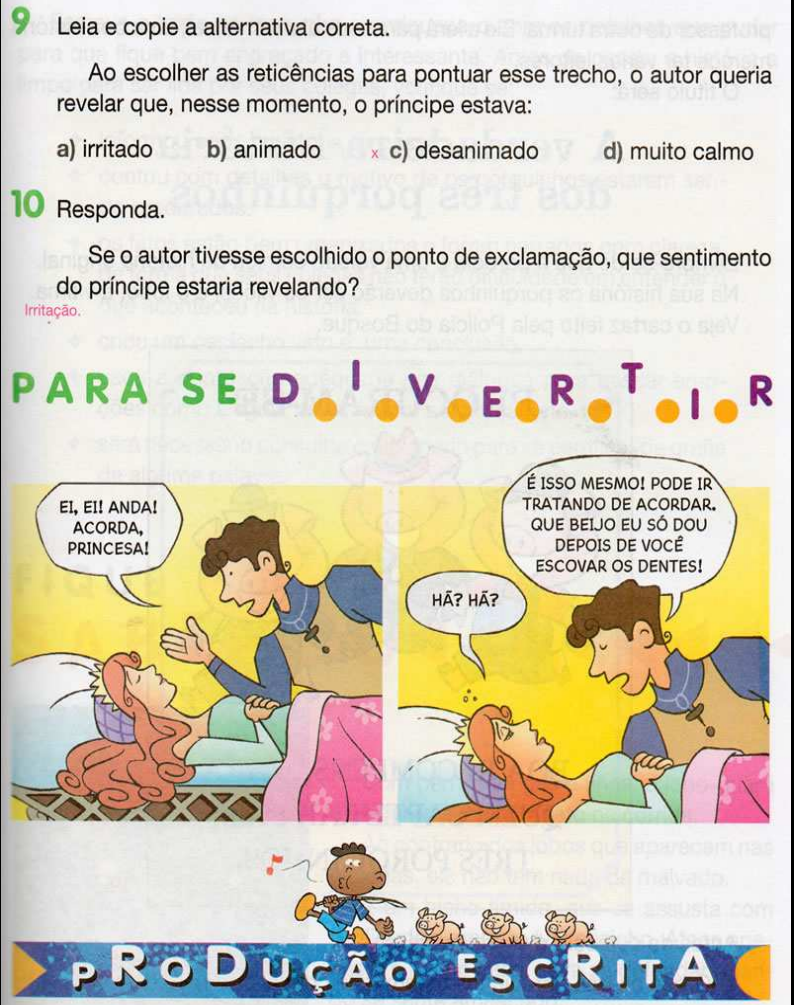

Você certamente conhece a história Os três porquinhos, não é mesmo? Então, invente uma paródia dessa história. As produções da classe serão trocadas entre os alunos para que escolham aquela que será doada a um 111 if: professor de outra turma. Ele a lerá para seus alunos. Afinal, uma boa história merece ter vários leitores.

O título será:

\section{A verdadeira história dos três porquinhos}

Lembre-se de que a paródia é uma versão cômica da história original. Na sua história os porquinhos deverão ser os vilões, e o lobo, a vítima. Veja o cartaz feito pela Polícia do Bosque.

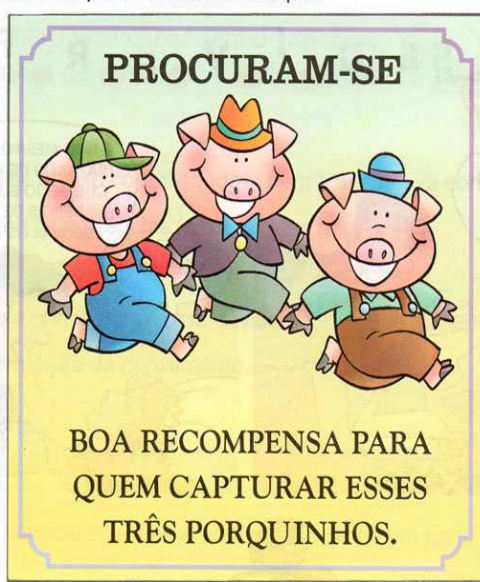

Antes de começar a escrever, pense:

$\downarrow$ O que os três porquinhos teriam feito com o lobo para estarem sendo procurados pela justiça?

Quem serão as outras personagens da história?

४ Qual é o problema da história?

\Como esse problema será resolvido?

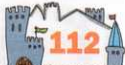


Escreva o texto no rascunho e enriqueça-o com os detalhes que puder para que fique bem engraçado e interessante. Antes de passar a história a limpo para ser lida por seus colegas, verifique se:

- informou onde a história se passa.

4 contou com detalhes o motivo de os porquinhos estarem sendo procurados.

- os fatos estão bem organizados e foram narrados com clareza, de forma que seus colegas não terão dificuldade em entender o que aconteceu na história.

- criou um desfecho, isto é, uma conclusão.

4 usou a pontuação adequada nos diálogos para passar emoções como alegria, raiva, medo, admiração etc.

- será necessário consultar o dicionário para se certificar da grafia de alguma palavra.

FIQUE

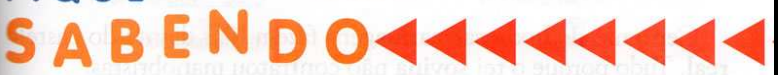

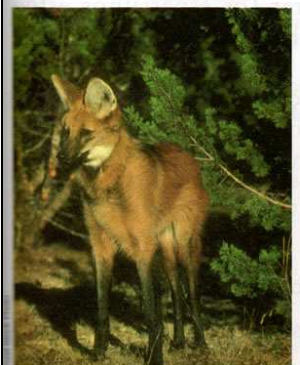

Com pernas longas e finas, o lobo-guará é elegante e muito rápido na corrida.

Ao contrário dos lobos que aparecem nas histórias, ele não tem nada de malvado.

É um bicho tímido, que se assusta com facilidade e prefere viver sozinho. Ataca apenas em último caso, para se defender quando se sente ameaçado.

Professor, se julgar conveniente, informe aos alunos que o lobo-

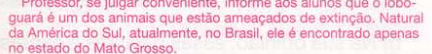
113 


\section{CONSIDERAÇÕES FINAIS}

PROVERBIOS Y CANTARES

Despertad, cantores: acaben los ecos,

empiecen las voces.

MACHADO, Antonio. Poesias Completas. Madrid, Espasa-Calpe, S.A., 1979, p. 361. 
Ao iniciar esta pesquisa, muitas vezes deparei-me com uma dúvida que me foi colocada por muitas pessoas com as quais tive oportunidade de trocar idéias:

"Como é possível incentivar os alunos a criarem seus textos a partir da idéia de que para escrever bem, devemos incentivá-los a copiar modelos?"

Para compreender essa hipótese, foi preciso retomar a habilidade principal esperada que os aprendizes consigam desenvolver ao longo da sua escolaridade: ou seja, produzir textos escritos coesos e coerentes, fazendo-se entender pelos seus interlocutores e adequando-os de acordo com a situação comunicativa.

Nesse sentido, a idéia de criação de textos estaria muito mais próxima da expressão produção de textos, pois não é esperado que as crianças, desde o início, já sejam capazes de produções absolutamente originais, como se fossem verdadeiros escritores. A atividade de escrita não pode ser vista como um dom, como uma atividade mágica, e sim como algo que pode ser ensinado nas escolas e aprendido pelos alunos.

É nessa concepção que surge a idéia do modelo: aprende-se com quem sabe mais e a partir de algo que já existe. Essa premissa me fez pensar em quais seriam os modelos, ou seja, as autoridades, que atuariam junto aos alunos nas escolas para ajudá-los a escreverem melhor. Muitos são os fatores que contribuem para a constituição de modelos, mas dois em especial chamaram-me a atenção durante os anos em que atuo como professora no ensino fundamental: o papel do professor e o do livro didático nas situações de escrita. Seriam eles os grandes responsáveis por definir caminhos e propor atividades, mostrando como se faz.

A presença dos livros didáticos nas salas de aula vem crescendo como importante aliado do professor na condução das aulas. Programas de análise, compra e distribuição de livros didáticos organizados pelo governo federal são formas de investir na formação do professor e na qualidade do ensino oferecido. Dessa forma, acabam por propor encaminhamentos e formas de como ensinar a ler e a escrever melhor.

A mediação realizada pelo livro didático, no caso específico desse estudo, confirma como as noções de autoridade e de autoria podem se relacionar. Ao atuar na ZDP dos alunos, conceito desenvolvido por Vygotsky, o livro didático também se torna responsável por esse processo, pois inicia algo nos aprendizes. Nesse sentido, as propostas de escrita devem estar 
cientes de que representam uma autoridade nos processos de desenvolvimento da escrita e do conhecimento, e devem estar de acordo com as concepções mais atuais sobre o ensino da língua. Segundo tais concepções, o texto é considerado uma unidade de ensino. Ou seja, é a partir dos textos lidos, tidos como bons modelos, que os alunos avançam em seus conhecimentos. Esses modelos darão pistas sobre o que e como escrever.

Essa concepção reforça uma das teorias desenvolvidas por George Steiner em seu livro Gramáticas da criação: estamos a todo o momento "imitando", ou melhor, repetindo modelos, ações e idéias de outros. Criamos a partir de algo que já existe, algo que já povoa o nosso imaginário, pois o ser humano se apropria das informações que circulam ao se redor e adaptaas de acordo com a sua realidade. O mundo da escrita seria como uma grande biblioteca, a Biblioteca de Babel, em que todas as situações já estariam de alguma forma prefiguradas, cabendo aos sujeitos encontrá-las e reorganizá-las a seu modo.

Trata-se de uma ruptura com uma idéia simplista de originalidade, ou seja, com a idéia de que existe um início inteiramente novo, algo nunca colocado antes no papel. De acordo com as idéias de Steiner, não existe uma criação em sentido estrito; o que o ser humano faz é sempre uma recriação, um inventário a partir de algo que já existe.

Produzir textos seria, portanto, na concepção desse autor, uma forma de recombinar, de justapor idéias, temas e textos que já se encontravam ao nosso redor. A idéia de criação em sentido estrito seria uma ilusão, pois a produção da escrita estaria muito mais próxima do conceito de paráfrase do que daquilo que é visto como inteiramente novo, como original. Parafrasear textos pode ser compreendido como uma forma de basear-se em textos ou idéias já existentes e apresentá-las de forma diferente, ou seja, explicar ou interpretar um texto usando suas próprias palavras.

Essa forma de expressão da criatividade prevê grande influência das idéias ao redor, ou seja, da cultura na qual o indivíduo estaria inserido e das vozes produzidas por outras pessoas e que tanto influenciam o conhecimento produzido por cada um. Para corroborar essa idéia, é possível citar também o conceito de polifonia desenvolvido por Bakhtin. De acordo com este autor, foi possível observar como estamos a todo o momento nos remetendo às idéias de outros e como somos ecos dessas vozes. 
Vale ressaltar que não se trata simplesmente de uma repetição de comportamentos e de idéias, pois não se espera uma atitude acrítica, mas sim reflexiva. Cabe ao próprio sujeito decidir o que fazer, baseando-se nas idéias já existentes. Dessa forma, quem ouve um enunciado responde a seu modo: concorda, discorda, completa, adapta etc; quem ouve está em processo de elaboração constante, ou seja, em um eterno devir.

A idéia de criatividade, portanto seria uma forma de "iniciar o continuar". Ressignificamos as idéias de outros para desenvolvermos as nossas próprias. A criação humana é sempre mediada por algo que já existe, mas há trabalho dos sujeitos nisso, não se trata de uma simples repetição. Acabamos por considerar a criação como o início de fazer algo aparecer, mas não a partir do nada. O autor é na verdade um "aumentador", ele aumenta o mundo a partir de algo que já existe. Podemos dizer, portanto, que somos na verdade "transformadores" da realidade.

Portanto, propor atividades que tenham como objetivo a reprodução/paráfrase, o decalque ou a recriação a partir de outros textos, ou seja, de modelos, é uma ótima forma de ajudar os alunos a se apropriarem de formas de escrever rumo à construção da sua própria autonomia.

Ao compilar boas propostas de produção de texto presentes nos livros didáticos que atendessem a essa concepção, foi possível perceber que esse tipo de trabalho só era mais perceptível em coleções cuja fundamentação teórica abordava os gêneros textuais. Ou seja, coleções em que havia um gênero de foco escolhido para análise não só do ponto de vista da compreensão de seu conteúdo, mas também da sua estrutura ou da sua linguagem. Dessa forma, as coleções que não partiam desse pressuposto não puderam ser incluídas nessa pesquisa, pois a condição para a produção, na concepção do autor, não era o gênero em estudo, mas o tema da unidade. Escrever sobre um assunto lido antes passava a ser a única pista dada pelo autor do livro didático para que os alunos escrevessem seus textos. Por exemplo, escrever uma notícia sobre um assunto que aparecesse em uma narrativa lida anteriormente não se apresenta como uma proposta muito adequada, pois os alunos não teriam analisado um bom modelo e não teriam ferramentas suficientes para escrever uma notícia eficiente.

Já as obras que apresentavam um bom modelo e analisavam sua estrutura são tidas como atividades mais eficientes para ajudar os alunos a escreverem de forma mais competente. Este tipo de trabalho só acontece de forma mais eficaz quando há uma consciência de que o 
que se está por trás é o gênero trabalhado e não o tema, o que acaba sendo um grande equívoco em muitos casos.

Um outro fator que foi possível de ser observado é que nas atividades de análise não bastava somente apresentar o gênero e solicitar a sua leitura, era preciso também apostar na percepção da sua estrutura composicional ou em alguma especificidade em relação à linguagem empregada, para que fosse possível ao aluno utilizá-lo como um modelo, uma base para escrever seus textos. Nesse sentido, o fato de que em alguns gêneros essa estratégia mostrou-se mais perceptível, devido principalmente à sua estrutura fixa, tornou-se um facilitador. No caso dos gêneros epistolares, como as cartas, por exemplo, ou dos gêneros jornalísticos, como a notícia, a condição para a produção era a retomada do modelo apresentado e das partes que os compunham. Este fato destacou ainda mais a importância do modelo nas situações de escrita como aquele que "coloca a palavra na boca do outro", ou seja, diz como fazer, monitorando a atividade, sem que, com isso, destitua-se o autor do seu próprio texto. Caberá a ele escrever o seu próprio texto, remetendo-se não a um único modelo, mas a tantos outros com os quais já tenha entrado em contato. É dessa reorganização, dessa recombinação de fatos que surge o novo.

Foi possível perceber também que as categorias de decalque e de reprodução/paráfrase são empregadas nas propostas de produção de textos em mais larga escala nas séries iniciais, pois escolher o que escrever e decidir como escrever são ainda muitas tarefas para quem ainda está se apropriando do sistema de escrita alfabética. Realizar um decalque a partir de um poema ou a reprodução de um conto tradicional é uma tarefa mais acessível para esses estudantes nesse momento de aprendizagem em que se encontram. $\mathrm{O}$ modelo, nesse caso, torna-se essencial para que os sujeitos possam lançar-se na tarefa de escrita de forma mais competente.

Portanto, escrever pode ser compreendido como uma tarefa que prevê o imitar, o repetir, mas não a cópia literal. Basear-se em um modelo e escrever a partir dele é aceitar que se aprende a partir de uma autoridade. Nesse sentido, todo exercício de autoridade é uma coação consentida, ou seja, exerce-se a autoridade na medida em que se assume a responsabilidade pelo outro e por si mesmo e esse sujeito não esboça uma reação sobre isso, mesmo que possa fazê-lo, pois aceita essa autoridade com o intuito de aprender com ela. 
Exercer uma autoridade sobre o outro, no caso da imitação de modelos, seria uma forma de contribuir para a evolução dos alunos, pois seria algo vindo de "alguém" que sabe mais para alguém que sabe menos. Porém, vale ressaltar que a autoridade não se trata de algo que deve ser seguido de forma rígida, sem reflexão. Cada um refaz e reorganiza as informações do seu jeito, incluindo outros dados a que tiver acesso. Esse fato alerta sobre os limites que o livro e o professor devem ter nessa tarefa de ensinar. Não podem ser autoritários, respeitando as vozes que ecoam do próprio sujeito, a partir de suas experiências anteriores. Devem também ser tolerantes para que não invadam a autoria do próprio sujeito, pois as pessoas buscam a todo o momento constituir-se como autoras, uma vez que ressignificam modelos com os quais entram em contato a partir das suas próprias experiências.

É dessa relação dialética entre autoria e autoridade que se apresenta o grande desafio da escola. Aprender com o outro e a partir do outro aparentemente pode ser visto como uma forma de não incentivar a criação e a autonomia. Mas, na verdade, aceitá-lo como um modelo, refletindo sobre suas contribuições, seria o ponto central do trabalho educativo para que o aluno crie seu próprio repertório e descubra seu próprio estilo de escrever. Essa liberdade só se constrói a partir dos modelos oferecidos por pessoas, materiais ou autores tidos como referência.

Essa concepção que prevê o "imitar" torna-se uma ajuda na tarefa de "criar". Trata-se de orientar, de monitorar o trabalho, de fazer a mediação entre os modelos que são apresentados aos alunos e o seu próprio processo de produção de textos. O uso da palavra acaba sempre sendo um uso criativo, pois cada um irá usá-la de uma maneira única. Essa forma pessoal de escrever surge a partir de uma submissão, mesmo que apenas por algum tempo, a uma autoridade, conceito muito bem ilustrado pelo poeta Manoel de BARROS em seu Livro das ignorãças:

"Repetir repetir - até ficar diferente.

Repetir é um dom do estilo.”(2001, p. 11)

Assim, em vez de apenas cercear ou coagir, repetir passa a ser um legítimo instrumento para fomentar a criação e, portanto, um caminho producente para a aprendizagem. 
VI

BIBLIOGRAFIA 


\section{Livros, revistas e sites consultados}

\section{LIVROS:}

ALLIENDE, Felipe e CONDEMARÍN, M, Mabel. A leitura: teoria, avaliação $e$ desenvolvimento. Porto Alegre: ArtMed, 2004.

ARANTES, Valéria Amorim (org.). Afetividade na escola: alternativas teóricas e práticas. São Paulo: Summus, 2003.

ARAÚJO, Ulisses F. Temas transversais e a estratégia de projetos. São Paulo: Moderna, 2003. ARENDT, Hannah. Entre o passado e o futuro. São Paulo: Perspectiva, 2005.

BAKHTIN M. Marxismo e filosofia da linguagem. São Paulo: Hucitec, 1986. . Estética da Criação Verbal. São Paulo: Martins Fontes, 1992.

BARROS, M. Livro das ignorãças. Rio de Janeiro: Record, 2001.

BORGES, Jorge Luis. Ficções. São Paulo: Globo, 1995.

CASTORINA, José Antonio; FERREIRO, Emília; LERNER, Délia. Piaget - Vygostky: novas contribuições para o debate. São Paulo: Ática, 1995.

CHARAudeau, P. e MAINGUENEAU, D. Dicionário de análise do discurso. São Paulo: Contexto, 2004.

CHARLES, C. M. Piaget ao alcance dos professores. Rio de Janeiro: Ao Livro Técnico, 1975.

COELHO, Nelly Novaes. Literatura infantil teoria, análise, didática. São Paulo: Moderna, 2000 .

COLL, César. O Construtivismo na sala de aula. São Paulo: Ática, 1998.

COLL, César. Psicologia e Currículo. São Paulo: Ática, 1998.

FARACO, Carlos Alberto (org.). Diálogos com Bakhtin. Curitiba: UFPR, 2001.

FORNAZIERI, C.C. Identidade e criação: o encontro com a autoridade e a tradição como fatores constitutivos do sujeito - tese de doutorado, FEUSP, São Paulo, 2005.

FREITAS, M.T.A. Vygotsky e Bakhtin, Psicologia e Educação: um intertexto. São Paulo: Ática, 2003.

GERALDI, J. W. (org.). O texto na sala de aula: leitura e produção. Cascavel: Assoeste, 1984. Linguagem e ensino: exercícios de militância e divulgação. Campinas: ALB e Mercado de Letras, 1996. . Portos de passagem. São Paulo: Martins Fontes, 1983. 
GOUVERNEMENT DU QUÉBEC, Québec schools on course: educacional policy statement. Québec: Ministère de l’Éducation, 1997.

HERNÁNDEZ, Fernando; VENTURA, M.A. A Organização do currículo por Projetos de Trabalho. Porto Alegre: Artes Médicas, 1998.

JOLIBERT, Josette. Formando crianças leitoras. Porto Alegre: Artmed, 1994. Formando crianças produtoras de texto. Porto Alegre: Artmed, 1994.

KAUFMAN, Ana Maria.; RODRÍGUEZ, Maria. Helena. Escola, Leitura e Produção de Texto. Porto Alegre: Artes Médicas, 1995.

KOJÈVE, Alexandre. La notion de l'autorité. Paris: Galimard, 2004.

LERNER, Delia. Ler e escrever na escola. Porto Alegre: Artmed, 2002.

MACEDO, Lino de. Ensaios Construtivistas. São Paulo: Casa do Psicólogo, 1994. Ensaios pedagógicos. Porto Alegre: ArtMed, 2004.

MACHADO, A. M. Como e por que ler os clássicos universais desde cedo. Rio de Janeiro: Objetiva, 2002.

MACHADO, Antonio. Poesias Completas. Madrid: Espasa-Calpe, S.A., 1979.

MACHADO, Nilson José. Conhecimento e valor. São Paulo: Moderna, 2004. . Epistemologia e didática. São Paulo: Cortez, 2000. - Educação e autoridade: responsabilidade, limites, tolerância.

Petrópolis, RJ: Vozes, 2008.

MEC/ SEF. Parâmetros Curriculares Nacionais: $1^{\circ}$ e $2^{\circ}$ ciclos: Língua Portuguesa. Brasília, 2000. Parâmetros Curriculares Nacionais: $3^{o}$ e $4^{o}$ ciclos: Língua Portuguesa. Brasília, 1998.

MEC/ SEB/ DPE. Ensino Fundamental de Nove Anos: Orientações para a inclusão da criança de seis anos de idade. Brasília, 2006.

MESERANI, Samir. O intertexto escolar: sobre leitura, aula e redação. São Paulo, Cortez, 1995.

MOLES, Abraham A. A criação científica. São Paulo: Perspectiva, 1971.

NASPOLINI, Ana Tereza. Didática de Português: leitura e produção escrita. São Paulo: FTD, 1996.

NÓBREGA, M. J. Paráfrase, autoria e processos de assimilação d a palavra do outro dissertação de mestrado, FFLCH-LE, São Paulo, 2000.

OLIVEIRA, Martha Khol de. Vygotsky: Aprendizado e desenvolvimento - um processo sóciohistórico. São Paulo: Scipione, 1993. 
OSTROWER, Fayga. Criatividade e processos de criação. Petrópolis: Vozes, 1984.

PERRENOUD, Philippe. Construir as competências desde a escola. Porto Alegre: Artmed, 1999.

REGO, Teresa Cristina. Memórias de Escola: cultura escolar e constituição de singularidades. Petrópolis, RJ: Vozes, 2003.

ROJO, Roxane (org). A prática da linguagem em sala de aula: praticando os PCNs. São Paulo, Campinas: EDUC, 2000.

SILVA, Ezequiel T. Elementos de pedagogia da leitura. São Paulo: Martins Fontes, 1998.

SOLÉ, Isabel. Estratégias de Leitura. Porto Alegre: Artmed, 1998.

STEINER, George. Extraterritorial. São Paulo: Companhia das Letras, 1990. . Gramáticas da criação. São Paulo: Globo, 2003. Linguagem e silêncio. São Paulo: Companhia das Letras, 1988.

TEBEROSKY, Ana e TOLCHINSKY, Liliana (orgs.) Além da alfabetização. São Paulo: Ática, 1996.

TEBEROSKY, Ana. Aprendendo a escrever. São Paulo: Ática, 1998.

VYGOTSKY, Lev. Pensamento e linguagem. São Paulo: Martins Fontes, 1991. . A Formação social da mente. São Paulo: Martins Fontes, 1984.

WEISZ, Telma. O diálogo entre o ensino e a aprendizagem. São Paulo: Ática, 1999. ZABALA, Antoni. A Prática Educativa: como ensinar. Porto Alegre: ArtMed, 1998.

\section{REVISTAS:}

Revista Educação e Pesquisa. São Paulo, FEUSP, v. 30, nº 3, set./dez. 2004.

\section{SITES:}

http://www.scielo.br http://portal.mec.gov.br 


\section{OBRAS DIDÁTICAS ANALISADAS}

CARPANEDA, I. e BRAGANÇA, A. Porta Aberta: língua portuguesa, $1^{\mathrm{a}}, 2^{\mathrm{a}}, 3^{\mathrm{a}}$ e $4^{\mathrm{a}}$ séries. São Paulo: FTD, 2005.

CARVALHO, C., PANACHÃO, D. KUTNIKAS, S. e SALMASO, S. Construindo a escrita, $1^{\mathrm{a}}, 2^{\mathrm{a}}, 3^{\mathrm{a}}$ e $4^{\mathrm{a}}$ séries. São Paulo: Ática, 2003.

CEREJA, W. R. e MAGALHÃES, T.C. Português: linguagens, $1^{\mathrm{a}}, 2^{\mathrm{a}}, 3^{\mathrm{a}}$ e $4^{\mathrm{a}}$ séries. São Paulo: Atual, 2006.

MODERNA (org), Projeto Pitanguá: português. Obra concebida, desenvolvida e produzida pela editora Moderna, $1^{\mathrm{a}}, 2^{\mathrm{a}}, 3^{\mathrm{a}}$ e $4^{\mathrm{a}}$ séries. São Paulo: Moderna, 2005.

ORCHIS, A. CHU, A. e SIMONCELLO, V. Registrando descobertas: língua portuguesa, $1^{\mathrm{a}}$, $2^{\mathrm{a}}, 3^{\mathrm{a}}$ e $4^{\mathrm{a}}$ séries. São Paulo: FTD, 2005.

SOARES, M. Português: Uma proposta para o letramento , $1^{\mathrm{a}}, 2^{\mathrm{a}}, 3^{\mathrm{a}}$ e $4^{\mathrm{a}}$ séries. São Paulo: Moderna, 1999. 
VII

ANEXO 


\section{A Biblioteca de Babel}

By this art you may contemplate the variation of the 23 letters...

The Anatomy of Melancholy, part. 2, sect. II, mem.IV.

O universo (que outros chamam a Biblioteca) constitui-se de um número indefinido, e quiçá infinito, de galerias hexagonais, com vastos postos de ventilação no centro, cercados por varandas baixíssimas. De qualquer hexágono, vêem-se os pisos inferiores e superiores: interminavelmente. A distribuição das galerias é invariável. Vinte estantes, em cinco longas prateleiras por lados, cobrem todos os lados menos dois; sua altura, que é a dos andares, excede apenas a de um saguão estreito, que desemboca em outra galeria, idêntica à primeira e a todas. À esquerda e à direita do saguão, há dois sanitários minúsculos. Um permite dormir em pé; outros satisfazer as necessidades fecais. Por aí passa a escada espiral, que se abisma e se eleva para o longe. No saguão há um espelho, que duplica as aparências fielmente. Os homens costumam inferir desse espelho que a Biblioteca não é infinita (se o fosse realmente para que essa duplicação ilusória?), prefiro imaginar que as superfícies polidas representam e prometem o infinito... A luz provém de algumas frutas esféricas que levam o nome de lâmpadas. Há duas em cada hexágono: transversais. A luz que emitem é insuficiente, incessante.

Como todos os homens da Biblioteca, viajei na minha juventude; peregrinei em busca de um livro, talvez o catálogo de catálogos; agora que meus olhos quase não podem decifrar o que escrevo, preparo-me para morrer, a poucas léguas do hexágono em que nasci. Morto, mãos piedosas não faltarão que me tirem pela varanda a fora; minha sepultura será o ar insondável: meu corpo se fundirá dilatadamente e se corromperá e dissolverá no vento originado pela queda, que é infinita. Afirmo que a Biblioteca é interminável. Os idealistas argúem que as salas hexagonais são uma forma necessária do espaço absoluto ou, pelo menos, de nossa intuição do espaço. Alegam que é inconcebível uma sala triangular ou pentagonal. (Os místicos pretendem que o êxtase lhes revele uma câmara circular com um grande livro circular de lombada contínua, que segue toda volta das paredes; mas seu testemunho é suspeito; suas palavras, obscuras. Esse livro cíclico é Deus.) Para mim é suficiente, por ora, repetir o ditante clássico: A Biblioteca é uma esfera cujo centro cabal é qualquer hexágono, cuja circunferência é inacessível.

A cada um dos muros de cada hexágono correspondem cinco prateleiras; cada prateleira encerra trinta e dois livros de formato uniforme; cada livro é de quatro centenas e dez páginas; cada página, de quarenta linhas; cada linha de umas oitenta letras de cor preta. Também há letras no dorso de cada livro; essas letras não indicam ou prefiguram o que dirão as páginas. Sei que essa inconexão, alguma vez, pareceu misteriosa. Antes de resumir a solução ( cuja descoberta, apesar de suas trágicas projeções, é talvez o fato capital da história ) quero rememorar alguns axiomas. 
O primeiro: A Biblioteca existe ad aeterno. Dessa verdade cujo corolário imediato é a eternidade futura do mundo, nenhuma mente razoável pode duvidar. $\mathrm{O}$ homem, o bibliotecário imperfeito, pode ser obra da sorte ou dos demiurgos malévolos; o universo, com sua elegante dotação de prateleiras, de tomos enigmáticos, de escadas infatigáveis para o viajante e de latrinas para o bibliotecário sentado, somente pode ser criação de um deus. Para perceber a distância que há entre o divino e o humano basta comparar estes rudes símbolos trêmulos que minha mão falível garatuja na capa de um livro, com as letras orgânicas do interior: pontuais, delicadas, negríssimas, inimitavelmente simétricas.

O segundo: $O$ número de símbolos ortográficos é vinte e cinco ${ }^{1}$. Essa comprovação permitiu, depois de trezentos anos, formular uma teoria geral da Biblioteca e resolver satisfatoriamente o problema que nenhuma conjetura desvendara: a natureza informe e caótica de quase todos os livros. $\mathrm{Um}$, que meu pai viu no hexágono do circuito quinze noventa e quatro, constava das letras M C V malevolamente repetidas da primeira linha até a última. Outro (muito consultada nesta zona) é um simples labirinto de letras, mas a penúltima página diz ó tempo tuas pirâmides. Já se sabe: por uma notícia justa, há léguas de cacofonias insensatas, de confusões verbais e de incoerências. (Sei de uma região agreste cujos bibliotecários repudiam o costume supersticioso e ão de procurar sentidos nos livros e o equiparam ao de procurá-los nos sonhos ou nas linhas caóticas da mão... Admitem que os inventores da escrita imitaram os vinte e cinco símbolos naturais, mas sustentam que essa aplicação é casual, e que os livros em si nada significam. Esse ditame, já veremos, não é completamente falso.)

Durante muito tempo, acreditou-se que esses livros impenetráveis correspondiam a línguas passadas ou remotas. É verdade que os homens mais antigos, os primeiros bibliotecários, usavam uma linguagem assaz diferente da que falamos agora; é verdade que algumas milhas à direita a língua é dialetal e que noventa andares mais acima é incompreensível. Tudo isso, repito-o, é verdade, mas quatrocentos e dez páginas de inalteráveis M C V não podem corresponder a nenhum idioma, por dialetal ou rudimentar que seja. Uns insinuaram que cada letra podia influir na subseqüente e que o valor de M C V na terceira linha da página 71 não era o que pode ter a mesma série noutra posição de outra página, mas essa tese vaga não medrou. Outros pensaram em criptografias; universalmente essa conjetura foi aceita, ainda que não no sentido em que a formularam seus inventores.

Há quinhentos anos, o chefe de um hexágono superior ${ }^{2}$ deparou com um livro tão confuso como os demais, porém que possuía quase duas folhas de linhas homogêneas. Mostrou seu achado a um decifrador ambulante, que lhe disse que estavam redigidas em português; outros the afirmaram que em iídiche. Antes de um século pôde ser determinado o idioma: um dialeto samoiedo-lituano do guarani,

\footnotetext{
${ }^{1} \mathrm{O}$ manuscrito original não contém algarismos ou maiúsculas. A pontuação foi limitada à vírgula e ao ponto. Esses dois signos, o espaço e as vinte e duas letras do alfabeto são os vinte e cinco símbolos suficientes que enumera o desconhecido (Nota do Editor.)

${ }^{2}$ Antes, em cada três hexágonos havia um homem. O suicídio e as enfermidades pulmonares destruíram essa proporção. Lembrança de melancolia indizível: às vezes, muitas noites viajei por corredores e escadas polidas sem encontrar um só bilbiotecário.
} 
com inflexões de árabe clássico. Também desvendou-se o conteúdo: noções de análise combinatória, ilustradas por exemplo de variantes com repetição ilimitada. Esses exemplos permitiram que um bibliotecário de gênio descobrisse a lei fundamental da biblioteca. Esse pensador observou que todos os livros, por diversos que sejam, possuem elementos iguais: o espaço, o ponto, a vírgula, as vinte e duas letras do alfabeto. Também alegou um fato que todos os viajantes confirmaram: Não há, na vasta biblioteca, dois livros idênticos. Dessas incontrovertíveis premissas deduziu que a Biblioteca é total e que suas prateleiras registram todas as possíveis combinações dos vinte e tantos símbolos ortográficos (números, ainda que vastíssimos, não infinito), ou seja, tudo o que é dado expressar: em todos os idiomas. Tudo: a história minuciosa do futuro, as autobiografias dos arcanjos, o catálogo fiel da biblioteca, milhares e milhares de catálogos falsos, a demonstração da falácia desses catálogos, a demonstração da falácia do catálogo verdadeiro, o evangelho, o comentário do comentário desse evangelho, a relação verídica de tua morte, a versão de cada livro em todas as línguas, as intercalações de cada livro em todos os livros.

Quando se proclamou que a Biblioteca abarcava todos os livros, a primeira impressão foi de extravagante felicidade. Todos os homens sentiram-se proprietários de um tesouro intacto e secreto. Não havia problema pessoal ou mundial cuja eloqüente solução não existisse: nalgum hexágono. $\mathrm{O}$ universo estava justificado, o universo usurpou bruscamente as dimensões ilimitadas da esperança. Naquele tempo falou-se muito das Vindicações: livros de apologia e de profecia, vindicavam para sempre os atos de cada homem do universo e guardavam arcanos prodigiosos para seu futuro. Milhares de cobiçosos abandonaram o doce hexágono natal e precipitaram-se escadas acima, movidos pelo oco propósito de encontrar sua vindicação. Esses romeiros disputavam nos corredores estreitos, proferiam obscuras maldições, estrangulavam-se nas escadas divinas, lançavam os enganosos livros no interior dos túneis, morriam despenhados pelos homens de regiões longínquas. Outros enlouqueciam... As vindicações existem (observei duas que se referem a pessoas do futuro, a pessoas talvez não imaginárias), mas os investigadores não recordavam que a possibilidade de que um homem encontre a sua, ou alguma pérfida variante da sua, é computável em zero.

Também se aguardou então o esclarecimento dos mistérios básicos da humanidade: a origem da Biblioteca e do tempo. É verossímil que esses graves mistérios possam explicar-se em palavras: se não bastar a linguagem dos filósofos, a multiforme Biblioteca produzirá o idioma inaudito que se requer e os vocábulos e gramáticas desse idioma. Faz já quatro séculos que os homens molestam os hexágonos... Existem investidores oficiais, inquisidores. Eu os vi no desempenho de sua função: chegam cansados sempre; falam de uma escada sem degraus que quase os matou; falam de galerias e de escadas com os bibliotecários; alguma vez, tomam livro mais próximo e o folheiam, em busca de palavras infames. Visivelmente, ninguém espera descobrir nada.

À desapoderada esperança, sucedeu, como é natural, uma depressão excessiva. A certeza de que alguma prateleira nalgum hexágono encerrava livros preciosos e de que esses livros preciosos eram inacessíveis, afigurou-se quase intolerável. Uma seita blasfema sugeriu que cessassem as buscas e que 
todos os homens misturassem letras e símbolos, até construir, mediante um improvável dom do acaso, esses livros canônicos. As autoridades viram-se compelidas a promulgar ordens severas. A seita desapareceu, mas na minha meninice vi anciãos que se ocultavam demoradamente nas latrinas, com alguns discos de metal num covilhete proibido, e debilmente arremedavam a divina desordem.

Outros, inversamente, acreditaram que o primordial era eliminar as obras inúteis. Invadiram os hexágonos, exibiam credenciais nem sempre falsas, folheavam com fastio um volume e condenavam prateleiras inteiras: a seu furor higiênico, ascético, deve-se a perda insensata de milhões de livros. Seu nome é execrado, mas aqueles que deploram os "tesouros" que seu frenesi destruiu, negligenciam dois fatos notórios. Um: a Biblioteca é tão imensa que toda redução de origem humana resulta infinitesimal. Outro: cada exemplar é único, insubstituível, mas (como a Biblioteca é total) há sempre várias centenas de milhares de fac-símiles imperfeitos: de obras que apenas diferem por uma letra ou por uma vírgula. Contra a opinião geral, atrevo-me a supor que as consequiências das depredações cometidas pelos Purificadores foram exageradas graças ao horror que esses fanáticos provocaram. Urgia-lhes o delírio de conquistar os livros do Hexágono Carmesin: livros de formato menor que os naturais; onipotente, ilustrados e mágicos.

Sabemos, igualmente, de outra superstição daquele tempo: a do Homem do Livro. Nalguma estante de algum hexágono (racionaram os homens) deve existir um livro que seja a cifra e o compêndio perfeito de todos os demais: algum bibliotecário o consultou e é análogo a um deus. $\mathrm{Na}$ linguagem desta zona persistem ainda vestígio do culto desse funcionário remoto. Muitos peregrinaram em busca dEle. Durante um século trilharam em vão os mais diversos rumos. Como localizar o venerado hexágono secreto que o hospedava? Alguém propôs um método regressivo: Para localizar o livro A, consultar previamente um livro B, que indique o lugar de A; para localizar o livro B, consultar previamente um livro $\mathrm{C}$, e assim até o infinito... Em aventuras dessas, prodigalizei e consumi meus anos. Não me parece inverossímel que nalguma divisão do universo haja um livro total ${ }^{3}$; rogo aos deuses ignorados que um homem - um só, ainda que seja, há mil anos! - o tenha examinado e lido. Se a honra e a sabedoria e a felicidade não estão para mim, que sejam para outros. Que o céu exista, embora meu lugar seja o inferno. Que padeça eu de ultraje e aniquilação, mas que num instante, num ser, Tua enorme Biblioteca se justifique.

Asseguram os ímpios que o disparate é normal na Biblioteca e que o razoável (e mesmo a humilde e pêra coerência) é quase milagrosa exceção. Fala (eu o sei) de "a Biblioteca febril, cujo os fortuitos volumes correm o incessante risco de transformar-se em outros e que tudo afirmam, negam e confundem como uma divindade que delira." Essas palavras, que não apenas denunciam a desordem mas que também a exemplificam, provam, evidentemente, seu gosto péssimo e sua desesperada ignorância. Com efeito, a Biblioteca inclui todas as estruturas verbais, todas as variantes, que permitem

\footnotetext{
${ }^{3}$ Repito-o: basta que um livro seja possível para que exista. Somente está excluído o impossível. Por exemplo: nenhum livro é ao mesmo tempo uma escada, ainda que, sem dúvida, haja livros que discutem e neguem e demonstrem essa possibilidade e outros cuja estrutura corresponde à de uma escada.
} 
os vinte e cinco símbolos ortográficos, porém nenhum só disparate absoluto. Inútil observar que o melhor volume dos muitos hexágonos que administro intitula-se Trono Penteado, e outro A cãibra de Gesso e outro Axaxaxas $m L \ddot{o}$. Essas proposições, à primeira vista incoerentes, sem dúvida são passíveis de uma justificação criptográfica ou alegórica; essa justificação é verbal e, ex hypothesi, já figura na Biblioteca. Não posso combinar certos caracteres

\section{dhcmrlchtdj}

que a divina Biblioteca não tenha previsto e que nalguma de suas línguas secretas não contenham um terrível sentido. Ninguém pode articular uma sílaba que não esteja cheia de ternuras e temores; que não seja nalguma dessas linguagens um nome poderoso de um deus. Falar é incorrer em tautologia. Esta epístola vazia e palavrosa já existe num dos trinta volumes das cinco prateleiras de um dos incontáveis hexágonos - e também sua refutação. (Um número $n$ de linguagens possíveis emprega o mesmo vocabulário; em alguns, o símbolo biblioteca admite a correta definição ubíquo e perdurável sistema de galerias hexagonais, mas biblioteca é pão ou pirâmide ou qualquer outra coisa, e as sete palavras que a definem não tem outro valor. Tu, que me lês, estás seguro de entender minha linguagem?)

A escritura metódica distrai-me da presente condição dos homens. A certeza de que tudo está escrito nos anula ou nos fantasmagoriza. Conheço distritos em que os jovens se ajoelham diante dos livros e beijam selvagemente as páginas, mas não sabem decifrar uma só letra. As epidemias, as discórdias heréticas, as peregrinações que degeneram inevitavelmente em bandoleirismo, dizimaram a população. Acredito ter mencionado os suicídios, mais freqüentes cada ano. Talvez a velhice e o medo enganem-me, mas suspeito que a espécie humana - a única - está por extinguir-se e que a Biblioteca permanecerá: iluminada, solitária, infinita, perfeitamente móvel, armada de volumes preciosos, inútil, incorruptível, secreta.

Acabo de escrever infinita. Não interpolei esse adjetivo por um costume retórico; digo que não é ilógico pensar que o mundo é infinito. Aqueles que o julgam limitado, postulam que em lugares remotos os corredores e escadas e hexágonos podem cessar inconcebivelmente - o que é absurdo. Aqueles que o imaginam sem limites, esquecem que os abrange o número possível de livros. Ouso insinuar esta solução do antigo problema: A Biblioteca é ilimitada e periódica. Se um eterno viajor a atravessasse em qualquer direção, comprovaria ao fim dos séculos que os mesmos volumes se repetem na mesma desordem (que, reiterada, seria uma ordem: a Ordem). Minha solidão alegra-se com essa elegante esperança ${ }^{4}$.

1941, Mar del Plata

BORGES, Jorge Luis. Ficções. São Paulo: Globo, 1995, p.84-92.

\footnotetext{
${ }^{4}$ Letizia Alvarez de Toledo salientou que a vasta Biblioteca é inútil; a rigor, bastaria um só volume, de formato comum, impresso em corpo nove ou em corpo dez, composto de número infinito de folhas infinitamente delgadas. (Cavalieri, em princípios do século XVII, disse que todo corpo sólido é justaposição de um número infinito de planos.) O manuseio desse vade mecum sedoso não seria cômodo: cada folha aparente se desdobraria em outras análogas; a inconcebível folha central não teria reverso.
} 